ADILSON LUIZ DA SILVA

\title{
A BIOPOLÍTICA NO "SÉCULO" DO CÉREBRO: EDUCAÇÃO, APRIMORAMENTO COGNITIVO E PRODUÇÃO DE CAPITAL HUMANO
}

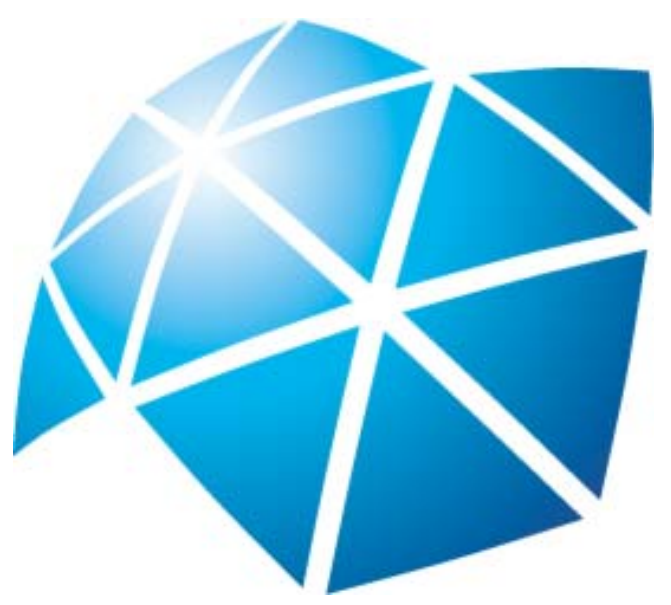

Presidente Prudente

2019 
ADILSON LUIZ DA SILVA

\section{A BIOPOLÍTICA NO "SÉCULO" DO CÉREBRO: EDUCAÇÃO, APRIMORAMENTO COGNITIVO E PRODUÇÃO DE CAPITAL HUMANO}

Tese de doutorado apresentada ao Programa de Pós-Graduação em Educação da Faculdade de Ciências e Tecnologia da Universidade Estadual Paulista, como requisito parcial para a obtenção do título de Doutor em Educação. Linha de pesquisa: Processos Formativos, Diferença e Valores. Orientador: Divino José da Silva 
\begin{tabular}{|l} 
S586b \\
Silva, Adilson Luiz da \\
A biopolítica no "século" do cérebro : educação, aprimoramento \\
cognitivo e produção de capital humano / Adilson Luiz da Silva. -- \\
Presidente Prudente, 2019 \\
$173 \mathrm{f}$. \\
Tese (doutorado) - Universidade Estadual Paulista (Unesp), \\
Faculdade de Ciências e Tecnologia, Presidente Prudente \\
Orientador: Divino José da Silva \\
1. Filosofia educacional. 2. Biopolitica. 3. Neurociência cognitiva. \\
4. Capital humano. 5. Resistencia ao governo. I. Título.
\end{tabular}

Sistema de geração automática de fichas catalográficas da Unesp. Biblioteca da Faculdade de Ciências e Tecnologia, Presidente Prudente. Dados fornecidos pelo autor(a).

Essa ficha não pode ser modificada. 


\section{UNIVERSIDADE ESTADUAL PAULISTA \\ Campus de Presidente Prudente}

\section{CERTIFICADO DE APROVAÇÃO}

TITULO DA TESE: A biopolitica no século do cérebro

AUTOR: ADILSON LUIZ DA SILVA

ORIENTADOR: DIVINO JOSÉ DA SILVA

Aprovado como parte das exigências para obtençăo do Título de Doutor em EDUCAÇÃO, pela Comissăo Examinadora:

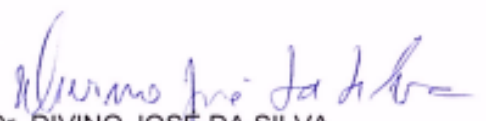

Prof. Dr. DIVINO JOSE DA SILVA

Departamento de Edycaçä

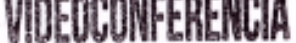

Prof. Dr. PEDRO ANGELO PAGNI

Departamento de Educaçăo / (UNESP) Faculdade de Filosofia e Ciências, Marilia - SP

Prof. Dr. ALEXANDRE H HLRDIDELARVALHO

Universidade Federal de Săo Paulo - UNIFESP

Prof. Dr. RODRIG OOHARBOSA LOPES

Departamento de Edưcação é Programa de Pós-graduação em Educaçăo / Faculdade de Ciências e Tecnologia - UNESP/Campus de Presidente Prudente

Dra. MARA SALGABO

Pós-doutoranda PNPD / Faculdade de Ciências e Tecnologia de Presidente Prudente

Presidente Prudente, 23 de agosto de 2019 
À Maria Angela Paschoaleto e Heitor Paschoaleto da Silva. 


\section{AGRADECIMENTOS}

Nas entrelinhas deste trabalho estão presentes muitas histórias, incertezas, angústias, medos, mas também alegrias, encontros e inspirações. Para um caipira, assim como eu bastante orgulhoso dessa condição e apegado a memórias rurais -, a experiência de produzir uma tese foi parecida com a de chocar um ovo: sentar, ler, pensar, escrever, pausar, recomeçar e aguardar os estalos e as rachaduras. Apesar da solidão dessa "atividade chocadeira", ela só foi possível graças à colaboração de pessoas importantes que se dispuseram a caminhar comigo, ou ainda com quem, inesperadamente, me encontrei. Assim, manifesto a todos minha sincera gratidão.

Aos meus pais, Milton e Maria, pelo exemplo de dedicação, amor, perseverança, simplicidade e sabedoria. Pessoas as quais as marcas sociais da injustiça foram cravadas na forma da exploração do trabalho infantil, impossibilitando-os do contato com a educação formal, mas que confiaram à escola a feliz esperança de emancipação dos filhos.

Aos meus irmãos, Ailton e Cláudia, pelo companheirismo, confiança, incentivo, exemplo de luta e resistência.

À Angela, pelo amor, carinho, dedicação, e por compartilhar comigo sonhos, alegrias e vida. Em momentos difíceis fez-me levantar e continuar. Seu exemplo, espírito e coragem me inspiram.

Ao Heitor, por ter me desviado do trabalho para as brincadeiras e animado a verticalidade das manhãs, ensinando-me o significado do amor incondicional e o sentido da desobediência.

Aos pequenos sobrinhos, Rafael, Sophia e Gabriel, seres queridos cuja potência de vida é capaz de "arrebentar os paralelepípedos".

Ao professor Divino, pela amizade, paciência, confiança, cuidado e disposição para ouvir. Suas orientações e exemplo profissional ultrapassam os limites do espaço acadêmico e inspiram ao enfrentamento dos obstáculos cotidianos. Ainda em 2014, sem conhecer-me, aceitou-me como aluno ouvinte e, desde então, vem proporcionando-me momentos de aprendizagem, possibilidades de debate e desenvolvimento humano. Com uma alegre desconfiança mineira, sabe dosar a profundidade da análise filosófica, os assuntos simples e sensíveis e a leveza poética. 
A Rodrigo Barbosa e Pedro Pagni, pela participação na banca de qualificação. Suas contribuições foram extremamente importantes; tiraram-me da monotonia do ninho e permitiram-me beber de muitas gotas de reflexão.

Aos professores e demais profissionais do Programa de Pós-Graduação em Educação da UNESP - campus de Presidente Prudente/SP -, por doarem tempo, energia e conhecimento, especialmente nesses "tempos" de ataques ao ensino público e à pesquisa.

Aos participantes do grupo de estudos sob a coordenação dos professores Divino e Rodrigo, pelos debates, reflexões e sinais de resistência.

À querida amiga de doutoramento Estéfani Ramos, pela sensibilidade, amizade e carinho. Nossas conversas nos intervalos ou no fim das aulas ajudaram-me a conter os desânimos, sorrir, organizar as ideias e acreditar no desfecho do trabalho.

A todos os amigos que conviveram comigo e fizeram parte, corajosamente, do mesmo processo de formação, em especial Guilherme Tommaselli, Alan Antunes, Keith Braga, Maria Josélia e Larissa Trindade.

Aos amigos e companheiros de trabalho no Instituto Federal do Mato Grosso do Sul (IFMS), campus de Três Lagoas/MS, Maria Celinei, Kleber, Joel, Ângelo, Paula, Gilmar, Orico, Mara, Camila, Renata e outros, pelo incentivo e exemplo de comprometimento com a Educação.

Aos estudantes do IFMS, campus de Três Lagoas/MS, verdadeiro motivo de todos os esforços, em quem deposito a esperança de um futuro mais justo e sábio.

Ao casal José e Eliana Sales, pelas conversas descontraídas, por compartilharem suas histórias como docentes e pesquisadores, pela companhia no vinho, amizade e confiança.

Aos amigos das reuniões de fim de semana, pela boa conversa, distração e planos de viagem e pescaria que nunca se realizam, Luís Gonzaga, Kenia, Thiago, Juliana, Paulo, Marila e Arnaldo.

À UNESP, por proporcionar-me uma formação profissional e humana desde a graduação.

Por fim, ao IFMS, pelo apoio institucional ao conceder-me licença integral para capacitar-me. 
O que sabe o homem, de fato, sobre si mesmo! [...] Não se lhe emudece a natureza acerca de todas as outras coisas, até mesmo acerca de seu corpo, para bani-lo e trancafiá-lo numa consciência orgulhosa e enganadora, ao largo dos movimentos intestinais, do veloz fluxo das correntes sanguíneas e das complexas vibrações das fibras! Ela jogou fora a chave: e coitada da desastrosa curiosidade que, através de uma fissura, fosse capaz de sair uma vez sequer da câmara da consciência e olhar para baixo, pressentindo que, na indiferença de seu não saber, o homem repousa sobre o impiedoso, o voraz, o insaciável.

(NIETZSCHE, 2007, p. 28-29). 


\section{RESUMO}

Este trabalho é de natureza teórica e busca analisar, filiando-se a uma perspectiva foucaultiana, alguns desdobramentos do biopoder no "século" do cérebro. Com os avanços das neurociências, principalmente a partir de 1990, fortaleceu-se um discurso acadêmico e laboratorial apregoando a equivalência entre o cérebro e o indivíduo e, com o passar do tempo, em virtude das mídias, da preocupação com o sofrimento psíquico e a saúde mental, entre outros - e ultrapassando seu espaço originalmente especializado -, esse discurso acabou por popularizar-se. Hoje o cérebro tornou-se uma espécie de "ator social", um ponto de referência para os processos de subjetivação e condução da vida, seu funcionamento é correlacionado a praticamente todos os aspectos humanos: moral, inteligência, humor, desempenho, eficiência, educação, entre outros. O objetivo deste trabalho foi mostrar a inserção desse órgão na moderna lógica do homo oeconomicus e, paralelamente, sinalizar para o fato de que o governo atual da vida está exigindo o seu mapeamento e manipulação. Ao se apropriar de noções das neurociências cognitivas, como plasticidade e neuroquímica, a biopolítica contemporânea e seu ideal de aperfeiçoamento do indivíduo-empresa, amplamente divulgado pela racionalidade neoliberal, encontra no cérebro um dispositivo de modelagem subjetiva e, fundamentando-se nele, desenvolve tecnologias de gestão do self. Entre essas tecnologias destacamos o neuroaprimoramento farmacológico, a neuroascese $\mathrm{e}$ a neuroeducação, defendendo a tese de que o projeto contemporâneo de governamentalidade da vida ganhou contornos demasiadamente sutis, sendo realizado por meio da gestão dos fenômenos mentais, entendidos agora como o resultado de processos neurais. Governar ou resistir passa pelo registro do cérebro - seja no trabalho, nos lares ou na escola, os indivíduos são, agora, sujeitos cerebrais.

Palavras-chave: biopolítica; capital humano; cérebro, neuroeducação. 


\begin{abstract}
The present work consists of a theoretical nature and seeks to present, allying itself to a Foucalt's perspective, some development of the biopower in the brain century. With the advance of the neuroscience, mainly since 1990, an academic and laboratorial speech strengthened to proclaim the equivalence between the brain and the individual and, as time passes, due to the media, the concern with the psychological suffering and mental health and so on - and exceeding its space originally specialized - this speech became popular. Today the brain became a sort of "social actor", as a reference to subjectivation processes and life conduction, its performance is correlated to almost all humans' aspects: moral, intelligence, humor, performance, efficiency, education, etc. The main goal of this work was to show the inception of this organ in the homo oeconomicus modern logic and, alongside, point out to the fact that the current management of life is demanding its mapping and handling. Overtaking the neuroscience cognitive notions, such as plasticity and neurochemistry, the contemporary biopolitics and its improvement ideal of the individual-enterprise, widely spread by the neoliberal rationality, it finds in the brain a subjective framing device and, bases itself in it, develops technologies of self-management. Among this technologies drugs neuroimprovement, neuroascesis and neuroeducation stand out, it supports the theses that the contemporary project of life's neuromanagement got quite subtle outlines, it is done by management of mental phenomena, understood currently as a result of neural processes. Managing or resisting goes through the brain registry - either at work or at home or at school, the individuals are subjectivated now by the brain's structure.
\end{abstract}

Keywords: Biopolitics, human capital, brain, neuroeducation 


\section{Sumário}

INTRODUÇÃO

CAPÍTULO 1

GOVERNANDO OS CORPOS E EMPRESARIANDO A VIDA 19

1.1 VIDA! QUAL VIDA? 22

1.2 DO PODER SOBERANO À BIOPOLÍTICA 28

1.3 GOVERNAMENTALIDADE LIBERAL

1.3.1 Governamentalidade neoliberal e teoria do capital humano 38

$\begin{array}{ll}\text { CAPÍTULO } 2 & 45\end{array}$

DO SELF COGITANTE (RES COGITANS) PARA UMA IDENTIDADE SOMÁTICA/CEREBRAL $\quad 45$

2.1 DO DUALISMO MENTE E CORPO PARA O MONISMO CEREBRAL E A
CONDUÇÃO DA VIDA

2.2 O SUJEITO CEREBRAL

2.2.1 Um aparte sobre a construção do sujeito cerebral 63

2.3 A BIOPOLÍTICA NO SÉCULO XXI

2.3.1. O self neuroquímico $\quad 81$

$\begin{array}{ll}\text { CAPÍTULO } 3 & 87\end{array}$

A POLÍTICA DO DESEMPENHO E A AMPLIAC̃̃̃O DOS BONS EQUIPAMENTOS

3.1 APRIMORAMENTO COGNITIVO E PRODUCÃO DE CAPITAL HUMANO 87

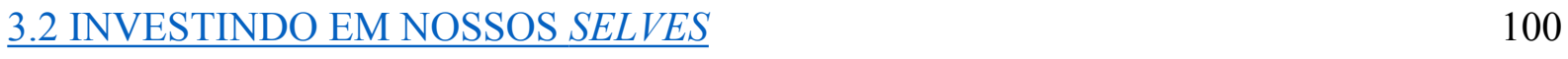

3.2.1 Aprimoramento farmacológico e capital mental 105

3.2.2 Ascese cerebral $\quad 112$

CAPÍTULO 4

NEUROEDUCAÇÃO, OBEDIÊNCIA BIOQUÍMICA E RESISTÊNCIA

4.1 PRÁTICAS NEUROEDUCATIVAS

4.1.2 (Bio) Medicalização no espaço escolar: aprimoramento e desobediência $\quad 134$

4.2 INSINUACÕ̃ES DE RESISTÊNCIA 143

4.2.1 "Sobras" e pequenas resistências 147

4.2.2 Uma resistência explosiva 151

$\begin{array}{ll}\text { CONSIDERACÕES FINAIS } & 157\end{array}$

REFERÊNCIAS $\quad 162$ 


\section{INTRODUÇÃO}

Meu cérebro é o meu segundo órgão favorito.

(WOODY ALLEN, SLEEPER)

Há já algum tempo, como observara Foucault (2014), que a política está preocupada em governar a vida, ora se centrando no corpo dos indivíduos, focando no seu adestramento e na ampliação de suas aptidões, ora no corpo-espécie, regulamentando os fenômenos de população - nascimento, mortalidade, saúde, duração da vida etc. No entanto, essa política, cujos primeiros vestígios remetem aos séculos XVI e XVII (FOUCAULT, 2014), nem sempre se manifestou da mesma forma e com a mesma intensidade sobre os mesmos elementos vitais, uma vez que seu campo de atuação, ainda que relacionado a um objeto comum, esteve aberto a todo tipo de modificações, principalmente por causa de avanços científicos, tecnológicos e o aparecimento de novas racionalidades de governo, como a liberal e a neoliberal.

Desde meados do século XX, o modo de percepção desse objeto político vem sofrendo transformações e, com ele, a própria concepção do que é o homem começa a ser modificada. Ademais, surgem também novas maneiras de nos relacionarmos com nós mesmos - cirurgias estéticas, transplantes de órgãos, seleção de embriões, remodelação dos humores e da inteligência -, levando alguns pensadores a falarem em uma política "da vida em si mesma" (ROSE, 2013, p. 16), ou, ainda, na emergência de uma "nova figura antropológica" (ORTEGA; VIDAL, 2007, p. 257). O que se nota, de maneira geral, é o desencadeamento de um novo estilo de pensamento ${ }^{1}$, significando não apenas uma mudança no modo como o conhecimento é produzido, mas também ao que pode, efetivamente, ser conhecido: "o cérebro, para as neurociências contemporâneas, não é o que era nos anos de 1950; 'o gene' [...] não é o que era antes de os genomas serem sequenciados” (ROSE, 2013, p. 27). A vida mesma se torna visualizável em outro nível, o corpo tangível, de molar "tal como delineado na tela de TV, em propagandas de produtos para a saúde e para a beleza e semelhantes" (ROSE, 2013, p. 26) é percebido agora no nível molecular. Fala-se, assim, em "canais de íons, atividades enzímicas, genes transportadores, potenciais de membrana" (ROSE, 2013, p. 26) e em neurônios, sinapses, neurotransmissores, entre outras coisas.

Acompanhando essas mudanças, tecnologias de visualização do corpo também são desenvolvidas, do estetoscópio, que permite perscrutar os órgãos e os sistemas do corpo chega-se a novas ferramentas ${ }^{2}$ que possibilitam ver o cérebro vivo, "pensando, recordando, ou

${ }^{1}$ Rose (2013) diz que essa noção foi inspirada em Ludwick Fleck (2010). 
enviando mensagens através das sinapses utilizando mensageiros químicos como a dopamina" (ANDREASEN, 2003, p. 158).

Ainda, se até a primeira metade do século XX, talvez sob os resquícios do pensamento cartesiano e dos conhecimentos psi, fundamentávamos muitas de nossas práticas, inclusive éticas e educacionais, em uma compreensão de nós mesmos como seres habitados por um mundo interior, hoje, essas práticas, ao serem submetidas a novos jogos de verdade, estão transformando-se e, com isso, "novas ciências neurológicas e comportamentais forjam laços diretos entre o que fazemos - como nos conduzimos a nós mesmos - e o que somos" (ROSE, 2013, p. 45). Nessa direção, sentimentos corriqueiros como medo, tristeza, alegria, aspirações, e mesmo o luto, passam a ser decodificados por um vocabulário médico, então estabelecemos novas relações com o corpo que incluem práticas cujo objetivo é reformulá-lo e aperfeiçoá-lo.

Em meio a essas mudanças, o grande destaque parece ser o cérebro - e, é claro, todas os saberes que o cercam. O cérebro tornou-se o órgão fundamental na representação de nossa identidade e subjetividade, e, mais, em torno dele se vem constituindo toda uma maneira de falar sobre a vida, sobre nossas experiências, condutas, pensamentos, sofrimentos, além de servir igualmente de fundamento para novas estratégias de potencialização das forças produtivas, um verdadeiro atrator no processo de formação de capital humano: "Das políticas públicas às artes, das neurociências à teologia, os humanos são geralmente tratados como reduzíveis aos seus cérebros" (ORTEGA; VIDAL, 2007, p. 258). Sumariamente, o cérebro converteu-se em importante referência para a política atual da vida, um marcador somático das práticas de subjetivação, ou, ainda, um dispositivo do biopoder (AZAMBUJA, 2012).

E é precisamente sobre esse assunto que pretendemos discorrer nas próximas páginas, isto é, a emergência do cérebro como um elemento a mais na lógica da biopolítica contemporânea. Se a sexualidade, como demonstra Foucault (2014), usufruía de uma posição estratégica entre o corpo do indivíduo e a população, constituindo, ao mesmo tempo, um alvo da disciplina e das operações biopolíticas, "o dispositivo do cérebro parece ser o grande agregador, o enlace e a força de mudança entre esses atravessamentos em nossa sociedade, tornando-se um alvo privilegiado tanto das biopolíticas, quanto das tecnologias específicas de modelagem subjetiva" (AZAMBUJA, 2012, p. 41). Prova disso é o grande destaque social e mesmo publicitário que é dado ao cérebro, incluindo a sua entrada em vários discursos, desde

\footnotetext{
${ }^{2}$ As técnicas de neuroimagiologia, segundo Andreasen (2003), podem ser divididas em estruturais (anatômicas), como a tomografia computadorizada e a ressonância magnética, e as técnicas funcionais (fisiológicas/neruorquímicas), tomografia computadorizada por emissão de fóton único, tomografia por emissão de positrões, ressonância magnética funcional e espectroscopia por ressonância magnética.
} 
o científico, passando pelo popular, econômico, clínico, religioso, até o educacional. O governo norte-americano, a exemplo, designou os anos de 1990 como "a década do cérebro", e, cerca de quatro anos depois, e de maneira um tanto relutante, os europeus declararam a própria década desse órgão. Atualmente, há aqueles que também dizem que estamos recémentrando no "século do cérebro" (ORTEGA; VIDAL, 2007; ROSE, 2013). Assim,

O cérebro surge como um déspota que domina a nossa subjetividade, um órgão imperador que rege estados de humor e define a nossa identidade. Falamos da química cerebral com certa naturalidade, comentamos sobre os efeitos dos neurotransmissores como se eles fossem nossos velhos conhecidos; em suma, falamos uma espécie de "linguagem da serotonina", que parece ser hoje hegemônica entre o público leigo, [...] Da insônia à inteligência, da "depressão" à "ansiedade" em suas várias manifestações, novas e velhas questões têm etiologia, cura ou debate ligados ao cérebro e aos neurotransmissores. (AZIZE, 2010, p. 6).

O cérebro, como diz Ehrenberg (2009), tornou-se uma espécie de "ator social" e, a partir disso, vem sendo inserido em cálculos políticos ${ }^{3}$, científicos e econômicos da atualidade. De certa forma, como procuraremos mostrar, o cérebro parece estar sendo agenciado por uma racionalidade neoliberal, enquadrado na moderna lógica do homo oeconomicus $^{4}$. Maximizar os estados mentais, conferir aos indivíduos maior capacidade de memória, atenção, maior controle sobre as emoções e volições por meio de investimentos cerebrais - produtos farmacêuticos, práticas de si cerebrais, ou neuroasceses, implantes, softwares computacionais e academias de fitness cerebral etc. -, parece implicar, no contexto da biopolítica contemporânea (ROSE, 2013), uma transformação de nós mesmos em "bons equipamentos" (FOUCAULT, 2008b) que possam ser disponibilizados ao mercado. Trata-se, é o que nos parece, da construção de um projeto de governamentalidade da vida por meio da gestão dos fenômenos mentais: “[...] se as disciplinas moldavam os corpos ao construir hábitos na memória corporal, as sociedades de controle modulam os cérebros" (LAZZARATO, 2006, p. 86). Nessa direção, o biopoder, ao focalizar o cérebro, move-se da estrutura tradicional da res extensa $a^{5}$ para o nosso "sistema operacional", atingindo a res cogitans c. $^{6}$

\footnotetext{
${ }^{3}$ Devemos considerar, no entanto, que a vida é que continua sendo o grande objeto desses cálculos, a decodificação do cérebro é uma maneira de significá-la. Pelo cérebro se reduzir o controle qualificado da vida ao seu mapeamento.

${ }^{4}$ Como veremos, na lógica do homo oeconomicus cada sujeito é incentivado a ser um "empresário de si mesmo", um gestor dos seus sucessos e fracassos, tendo como juiz de suas escolhas o próprio mercado.

${ }^{5}$ Coisa extensa, corpo.
} 
Com isso, percebemos certa necessidade de compreender os efeitos de verdade que tomam forma mediante discursos e saberes que nos atribuem uma identidade cerebralizada. Em outros termos, não nos interessará aqui questionar a(s) "verdade(s)" do discurso neurocientífico nem descrever detalhes da estrutura encefálica, mas pensar os efeitos de poder dessas verdades. Assim, pretendemos refletir sobre as consequências sociais de uma governamentalidade da vida que assume em seus cálculos - como mais um elemento estados mentais, admitindo-os como resultado causal dos processos cerebrais. Analisaremos o significado dessas mudanças para as relações pessoais e interpessoais, seus efeitos na formação contemporânea do indivíduo e da sociedade e suas consequências para o campo educacional.

Para mostrar essa investida da política da vida sobre o cérebro e tentar compreender alguns de seus efeitos, dividiremos o trabalho em quatro capítulos, além de uma consideração final. No capítulo 1, apresentaremos a revisão bibliográfica abordando o ingresso do fenômeno da vida no âmbito político. Pensamos que a realização dessa tarefa é importante porque o processo de cerebralização do self faz parte do registro biopolítico, especialmente no que diz respeito à abertura de uma identidade cerebralizada aos cálculos do poder. Indicaremos, inicialmente, os vestígios de uma política da vitalidade no pensamento de Hannah Arendt (2010), para quem o ponto central de todas as preocupações modernas foi uma certa instrumentalização da política pelo mero viver. Em seguida, com base no pensamento de Foucault (2014, 2008a, 2008b), discorreremos, introdutoriamente, sobre o surgimento do biopoder, o investimento no corpo vivo, a otimização e gestão da vida. O objetivo envolve apresentar alguns conceitos importantes que fundamentem os capítulos seguintes, principalmente oferecendo subsídios para entender como uma nova forma de compreensão de nós mesmos - que reduz a identidade e subjetividade à estrutura cerebral - pode ser usada de acordo com os propósitos de uma governamentalidade biopolítica. Discutiremos, então, os conceitos de técnica disciplinar, biopolítica, dispositivo de segurança, governamentalidade, liberalismo, neoliberalismo e capital humano.

No capítulo 2, abordaremos o que parece ser uma virada ontológica, isto é, o deslocamento de uma interpretação dualista do ser humano para outra monista, e a emergência daquilo que Ortega e Vidal (2007) chamam de sujeito cerebral e Rose (2013) de self neuroquímico. Trata-se aqui de averiguar a incorporação do cérebro aos saberes que

\footnotetext{
${ }^{6}$ Coisa pensante, mente. Devemos observar que a mente, na lógica do biopoder - acompanhada pelo desenvolvimento das ciências do cérebro -, não é vista como uma substância distinta do corpo, mas um epifenômeno.
} 
versam contemporaneamente sobre a nossa identidade, mas também de analisar a inserção desse órgão dentro de um cálculo e governo das condutas. Assim, discorreremos acerca do processo de somatização e cerebralização da subjetividade e, associado a isso, conjecturaremos o surgimento de um projeto de governamentalidade da vida por meio de um enquadramento dos fenômenos mentais - entendidos agora enquanto processos biológicos causados por relações neuronais. O sujeito cerebral, como veremos, vem ganhando destaque no contexto da biopolítica do século XXI, marcada principalmente por mudanças na racionalidade científica e nas tecnologias de governo da vida. Rose (2013), por exemplo, comenta sobre uma política "da vida em si mesma" e/ou na crença de que é possível manipular e incrementar livremente a vitalidade humana, órgãos e cérebros. O objetivo, então, é destacar um duplo fenômeno: o cérebro aparecendo como o órgão definidor da identidade e, associado a isso, uma política da vida que submerge na molecularidade do corpo. Nesse contexto, a positividade do poder parece rearticular-se nos discursos que incentivam a potencialização do cérebro, oferecendo ares para um projeto contemporâneo de governamentalidade da vida, especialmente pela inserção do "cérebro melhorado" na lógica do homo oeconomicus.

No capítulo 3, discutiremos sobre a política de aprimoramento cognitivo propagada pelos novos saberes, principalmente por aqueles que defendem uma correspondência entre o self e o cérebro. A ideia é mostrar que o biopoder se está refazendo, ampliando seus tentáculos da anatomia "dura" dos corpos, como acontecia na era do capitalismo industrial, em que o interesse era reter do trabalho a força e o tempo, para uma espécie de flexibilidade maquínica. Se na dinâmica do neoliberalismo o indivíduo é obrigado a investir em si mesmo, uma vez que o seu fluxo de renda depende do conjunto de suas competências, habilidades e aptidões, então, ao considerar a identidade como aquilo que resulta das intrincadas relações neuroquímicas, o investimento em "si mesmo" passará a contar com técnicas de reificação da subjetividade. Entre as modalidades de aprimoramento, destacaremos a farmacológica e a neuroascese. A primeira diz respeito à inserção de substâncias químicas, como o cloridrato de metilfenidato, em estratégias de melhoramento das performances educacionais e profissionais. Grupos de pesquisadores, geralmente ligados a empresas farmacêuticas, vêm reivindicando, como veremos, a regulação e liberação de substâncias potencializadoras, o que de certa maneira acaba por corroborar uma rearticulação do biopoder, mas agora sob uma roupagem "molecular". A segunda modalidade, por sua vez, refere-se à práticas como ginástica cerebral, neuróbica e/ou autoajuda cerebral, que prometem esculpir a identidade, insinuam um 
"cuidado de si" e inserem-se nas demandas de maximização do desempenho corporal da cultura somática e da biossociabilidade. Trata-se, aqui, de problematizar o discurso da "ascese" cerebral - ou do "cuidado, contemporâneo, de si" - e mostrar sua filiação às formas de governo da vida.

No capítulo 4, abordaremos três assuntos principais: neuroeducação, obediência bioquímica e resistência. Inicialmente, discorreremos sobre as técnicas de subjetivação que se estão espalhando no universo educacional e, de algum modo, agenciam as potências cognitivas e afetivas daqueles que ainda estão em idade escolar. Mostraremos que os proponentes do saber conhecido como neuroeducação, ao recorrerem à noção de plasticidade cerebral, estão identificando meios para modelar, potencializar e conduzir as conectividades neurais que o aprendiz, de acordo com os imperativos da racionalidade econômica, é "convidado" a ter. Trata-se, assim, de apontar um saber que vem sendo desenvolvido com o objetivo de criar, via cérebro, um tipo especial de "máquina" que irá produzir fluxos de renda.

Na sequência, ao propor um debate sobre obediência bioquímica, veremos que, se os sujeitos desviantes, como apontara Foucault (2013a), já foram objetos de vigilância panóptica e de uma correção disciplinar fundamentada em técnicas e mecanismos de biopoder centrados em seu corpo (entendendo-os em sua dimensão macro), agora essas técnicas de correção tornaram-se extremamente sutis e são projetadas para agir na interioridade biológica do indivíduo, isto é, em seus neurônios, neurotransmissores, sinapses, hormônios, genes etc. Assim, o ponto de referência para se abordar o "desvio", como veremos, vem deslocando-se dos valores morais e das relações interpessoais para a bioquímica cerebral dos indivíduos e, em vez de agentes disciplinadores sugerindo a "palmatória", temos atualmente peritos da vida que acreditam ser capazes de "corrigir" os desviantes por meio de prescrições medicamentosas: "O chicote foi substituído por um conveniente sistema de administração oral” (PRECIADO, 2018, p. 221). Nessa direção, a versão atual do biopoder passa a ser localizada, por exemplo, na figura da criança-aluna com Transtorno do Déficit de Atenção com Hiperatividade (TDAH), para quem é prescrito o uso de Ritalina - medicamento conhecido também como "droga da obediência".

Por último, atentando para a observação feita por Foucault (1995) de que só existe poder onde está presente a possibilidade de resistir, verificaremos algumas "insinuações de resistência" ao governo da vida. Para isso apresentaremos duas vias de reflexão: na primeira discutiremos sobre uma face-sujeito que eventualmente diz "não" para alguns modos particulares de pastoreio - "não quero ser doutor" (BARROS, 2003), "não vou agir como um 
pré-doente" (ROSE, 2013), "não sou doente e nem preciso ser curado" (ORTEGA, 2008a), "não me defino enquanto homem ou mulher" (PRECIADO, 2018), "não preciso tomar Ritalina" (BARBARINI, 2014), entre outros. Tratando-se de manifestações, às avessas, de algumas "identidades cerebrais" tidas como "anômalas" e muitas vezes relegadas à condição de marginalidade. No entanto, em sua aparente impotência, geralmente tipificada à luz da interpretação econômica, mostram-se resistentes: "O corpo se revela aí como sinônimo de certa impotência, mas é aqui que se precisa pensar nessa virada. É dessa impotência que ele extrai uma potência superior" (PELBART, 2007, p. 63).

Sinalizaremos também para "outra" forma de resistência ao biopoder - mais primitiva -, que não se apoia necessariamente na face-sujeito, senão em sua própria destruição. Referese a um potencial de ação e reação da vida mesma, uma "força" capaz de emergir catastroficamente do próprio cérebro, de sua plasticidade ou daquilo que Malabou (2014, p. 14) chama de "poder de explosão plástica ontológica e existencial da subjetividade e identidade". Se as características do cérebro permitem instaurar uma cultura do "sim", do "a mais" cognitivo e afetivo, ou esculpir a identidade de modo que favoreça a ótima performance produtiva, de outro lado é no cérebro que estará inscrito também o poder de desorganizar o governo da vida.

Em suma, nosso objetivo é compreender os signos da biopolítica no "século do cérebro", entender a entrada desse órgão em um cálculo político, econômico, científico e mesmo educacional, e, além disso, tal como indicado, sugerir e defender a ideia de que a governamentalidade da vida foi aperfeiçoada, não se tratando mais de simplesmente disciplinar os corpos e regular a população, mas de fazê-lo molecularmente, desde dentro e até a "alma". O biopoder, em seu afã de otimização das forças vitais, mira agora à "caixapreta" do indivíduo, seu "sistema operacional", seu cérebro-software. 


\section{CAPÍTULO 1}

\section{GOVERNANDO OS CORPOS E EMPRESARIANDO A VIDA}

Em uma das versões do mito criacionista grego, Ésquilo (1999) afirma que os homens teriam sido feitos por Prometeu (deus da previsão), que os formou do barro. Apesar de terem sido criados à imagem das divindades, permaneceram inicialmente desprovidos de toda a inteligência. No entanto, Prometeu, que era simpático aos homens, teria roubado deliberadamente uma faísca do fogo divino e lhes entregado, concedendo-lhes, assim, uma primeira centelha de sabedoria, o que lhes permitiu construir uma existência totalmente singular: "O fogo, essa força divina, torna-se o símbolo sensível da cultura. Prometeu é o espírito criador da cultura" (JAEGER, 1995, p. 309). Consta nessa narrativa que, com a ajuda da faísca dos deuses, os homens poderiam, tecnicamente, dominar a natureza e, mais ainda, transformar a realidade de sua própria existência.

Após o crime de Prometeu, com o objetivo de punir os homens, por ordem de Zeus todos os deuses concorreram para o surgimento de Pandora, a primeira mulher: "Para compensar o fogo lhes darei um mal, com o qual todos se encantarão em seu espírito" (HESÍODO, 2012, vv. 55-60). Pandora teria sido criada à imagem das deusas imortais: jovem, virgem, bela e desejável. Zeus ordenou, então, que ela fosse enviada como presente a Prometeu, bem como ao seu irmão Epimeteu, e determinou a ela que levasse consigo uma caixa, a qual foi instruída a não abrir. No entanto, tomada por uma imensa curiosidade, Pandora teria transgredido a instrução, terminando por libertar de dentro da caixa todos os males da humanidade. Como é bem sabido, em um último e desesperado instante, Pandora teria fechado a caixa e conseguido reter em seu interior um valioso e derradeiro item, a esperança.

Observando despretensiosamente essa narrativa - no que diz respeito a uma incursão pela mitologia -, percebemos uma espécie de sentimento trágico em relação a uma ontologia de nós mesmos. Ao mesmo tempo em que nos vemos libertos por meio do saber de uma existência inconsciente e débil, pelo mesmo motivo parece que nos sentimos amaldiçoados. $\mathrm{O}$ conhecimento que emancipa o ser humano aparentemente é o motivo de seu aprisionamento, ou de sua maldição e desgraça.

\footnotetext{
${ }^{7} \mathrm{Na}$ Antiguidade helênica, o mito de Prometeu foi tratado em quatro obras: Protágoras, de Platão; Prometeu, de Ésquilo; Teogonia, os trabalhos e os dias, de Hesíodo.
} 
Ainda que consideremos algumas diferenças contextuais, o interessante é que essa mesma imagem e/ou sentimento, insistentemente, aparecem em outras narrativas, a exemplo do que acontece no mito judaico-cristão, em especial naquele que trata da gênese humana. Lembremos rapidamente que, no primeiro livro da Bíblia, Deus teria expulsado o primeiro homem e a primeira mulher do paraíso por terem comido o fruto proibido da árvore da ciência (do conhecimento do bem e do mal). Ao serem expulsos, teriam sido lançados no mundo e condenados a viver do trabalho e na dor. Ademais, tiveram que transformar com as mãos os elementos disponíveis na natureza e produzir a sua própria forma de vida.

Ora, a despeito de toda a fantasia e das narrativas que privilegiam uma origem solene do humano - afinal, "gosta-se de acreditar que as coisas no início se encontravam em estado de perfeição; que elas saíram brilhantes das mãos do criador, ou na luz sem sombra da primeira manhã” (FOUCAULT, 2015, p. 59) -, pensamos que essas histórias talvez representem um desejo humano comum e primordial, relatado até mesmo por Aristóteles (1984, p. 11), quando diz: "Todos os homens têm, por natureza, desejo de conhecer”. O conhecimento, tal como sugerido, indicaria então um rompimento trágico do homem com Deus(es) e a fabricação de um universo de artificialidades (cultura) que sobreporia o humano a toda a natureza.

Curiosamente, em meados do século XX, a pensadora Hannah Arendt (2010), no prólogo de seu livro A condição humana, indica ter secularizado essas mesmas imagens. Se, na mitologia judaico-cristã, a colheita do fruto da árvore do conhecimento teria sido a causa da expulsão do homem do Paraíso e, na mitologia grega, a faísca da razão nos condenara a uma infinidade de males, para Arendt (2010), é o próprio desenvolvimento tecnocientífico ${ }^{8}$ que estaria provocando a expulsão do homem da Terra e o seu rompimento não com Deus e/ou deuses, mas com a condição essencial de humanos.

Nessa direção, a autora analisa os desdobramentos de alguns eventos de sua época, especialmente os tecnocientíficos, e a partir daí faz algumas conclusões interessantes. Ao reportar-se ao lançamento do primeiro satélite ao espaço, em 1957, por exemplo, Arendt (2010) reflete sobre o que denomina de "mundo moderno" e diz que esse lançamento representa a concretização de um estranho desejo impresso no espírito humano: o de escapar da própria condição de humanos.

\footnotetext{
8 Entendemos por tecnociência os empreendimentos direcionados à manipulação da natureza conforme a necessidade e a utilidade humana e também aqueles destinados a conhecer e manipular o próprio ser humano de modo que o altere.
} 
A reação imediata, expressa no calor da hora, foi alívio ante o primeiro "passo para a fuga dos homens de sua prisão da Terra". E essa estranha declaração, longe de ter sido o lapso acidental de algum repórter norteamericano, refletia involuntariamente a extraordinária frase gravada há mais de 20 anos no obelisco fúnebre de um dos grandes cientistas da Rússia: "A humanidade não permanecerá para sempre presa a Terra”. (ARENDT, 2010, p. 2).

Considerando que a natureza e tudo o que fazemos ao produzir a nossa existência nos condiciona, escapar da condição humana significaria a possibilidade de nos desvencilharmos, em princípio, da própria natureza. Se em algumas imagens mitológicas o ser humano é amaldiçoado ou expulso de sua primeira morada, agora ele mesmo colaborará e conscientemente desejará a sua saída. O lançamento do primeiro satélite corroboraria esse desejo, pois, ao erguer os olhos da Terra para os céus, o homem teria conseguido pela primeira vez observar uma coisa produzida por ele mesmo, concorrendo, mesmo que por um curto espaço de tempo, com os corpos celestes e seus movimentos. Assim, tomando como base esse evento, além de um relato jornalístico, talvez imperceptíveis para muitos, Arendt (2010) inicia uma espécie de diagnóstico do mundo moderno.

\begin{abstract}
A banalidade da declaração não deve nos levar a desconsiderar o quão extraordinário ela de fato é, pois, embora os cristãos tenham chamado a Terra de vale de lágrimas e os filósofos tenham considerado o corpo uma prisão da mente ou alma, ninguém na história da humanidade jamais havia concebido a Terra como prisão para os corpos dos homens nem mostrado tal avidez por ir, literalmente, daqui à Lua. (ARENDT, 2010, p. 2).
\end{abstract}

Há, então, a constatação de um desejo sintomático do ser humano de superar a natureza, o qual, em certo sentido, pode ser associado a um impulso de fabricação de outra condição de vida. Escapar da Terra ou fugir da natureza parece significar, nesse contexto, a possibilidade de produção tecnocientífica de outros condicionantes e de outra existência. Com isso, Arendt (2010) aponta para o distanciamento de uma linha que até então unira o homem e a natureza, representado pelo fenômeno da vida - indica uma divisão entre a ideia tradicional de homem e um devir do próprio homem.

De certo modo, o lançamento do primeiro satélite ao espaço figuraria como a ponta de um iceberg, pois o mesmo desejo de escapar do "aprisionamento" na Terra estaria manifestando-se também em outros empreendimentos modernos, como na "tentativa de criar a vida em uma proveta, no desejo de misturar, 'sob o microscópio, o plasma seminal 
congelado de pessoas de comprovada capacidade, a fim de produzir seres humanos superiores' e 'alterar [lhes] o tamanho, a forma e a função"” (ARENDT, 2010, p. 3).

Atualizando as intenções obscuras envolvendo o lançamento de um satélite, talvez pudéssemos acrescentar também, em paralelo com os exemplos de Arendt (2010), outros procedimentos que atestariam esse desejo de produzir uma nova condição, como cirurgias estéticas, prolongamento de membros, redesignação sexual, transposição das normas de envelhecimento por meio de terapias de reposição hormonal, uso de medicamentos para aumentar a virilidade, remodelar e modelar o humor, o sono, a atenção, a inteligência, entre outros. De maneira geral, a ponta desse iceberg, ou o desejo de criar uma outra forma de existência, talvez possa ser compreendida como uma sinalização para aquilo que hoje muitos denominam de "pós-humanismo" e Rose (2013) chama de uma "forma de vida emergente". Dá a entender que o presente, “apesar de não ser radicalmente diferente daquilo que o precede, pode, apesar disso, ser um momento dentro do processo no qual algo de novo está tomando forma" (ROSE, 2013, p. 120). Esse algo, ou essa vida emergente, de algum modo, como veremos, parece estar relacionado ao processo de entrada dos fenômenos biológicos em um cálculo político, científico e econômico. Para Arendt (2010, p. 333), trata-se da "vitória do animal laborans", enquanto para Foucault (2008b) se refere ao "nascimento da biopolítica".

\subsection{VIDA! QUAL VIDA?}

Seguindo a tradição aristotélica de pensamento, Arendt (2010) afirma que é possível distinguir, no que diz respeito à vida humana, duas ordens de existência: zoé e bíos politikos. Em um primeiro momento, nascemos e somos acolhidos por aqueles que aqui já estão, inserimo-nos no mundo natural atendendo à emergência bruta e singular da própria vida. Esse evento, circunstancial e primeiro, faz do homem e do animal entes biológicos comuns (zoé). Aparecemos no mundo como estrangeiros e permanecemos durante algum tempo como estrangeiros, indistintamente viventes, em uma Terra que se revela gratuita. A vida, nesse primeiro instante, é uma espécie de desabrochar espontâneo. No entanto, em um segundo momento, depois de despertarmos, ao agir e discursar, tencionando e estendendo a vida no mundo, emergimos em uma espécie de segunda vida, em uma bios politikos.

A principal característica dessa vida especificamente humana, cujo aparecimento e desaparecimento constituem eventos mundanos, é que ela é plena de eventos que no fim podem ser narrados como uma estória (story) e estabelece uma biografia; era essa vida bios, em contraposição à mera zoé, 
que Aristóteles dizia ser "de certa forma uma espécie de práxis". (ARENDT, 2010, p. 120).

Se ao nascer somos entes indistintos, ao emergir na segunda vida, por meio de palavras e atos, tornamo-nos para o mundo e para nós mesmos, constituímos (e/ou absorvemos) uma subjetividade e objetamos o mundo. Segundo Arendt (2010), a primeira ordem de existência refere-se à vida biológica e a segunda, à política.

No livro $A$ condição humana, a pensadora sugere um percurso que vai da primeira ordem de existência para a segunda e, ao mesmo tempo, abre espaço para reflexões que enfatizam uma estranha e sintomática tendência, especificamente moderna, que é a subsunção da zoé à política. Arendt (2010) apresenta a tese de que o evento decisivo da política do mundo moderno, que por sua vez traduz uma ruptura com os períodos anteriores, é o ingresso no âmbito político da vida biológica. A politização da existência biológica, ou a instrumentalização da política pelo mero viver, é compreendido como o ponto central de todas as preocupações modernas: "Seja como for, a era moderna continuou a operar sob a premissa de que a vida, e não o mundo, é o bem supremo do homem” (ARENDT, 2010, p. 398).

De algum modo, essa premissa que afirma a entrada dos fenômenos vitais humanos na esfera política é uma das mais importantes - antecedendo o pensamento de Foucault (2014) a sinalizar o início de uma investida do poder no campo biológico. Assim, uma das condições para a sua sustentação afigura ser a identificação de algumas atividades fundamentais, constitutivas e mantenedoras do ser humano traduzidas pela filósofa como vita activa: "Com a expressão vita activa, pretendo designar três atividades humanas fundamentais: trabalho, obra e ação. São fundamentais porque a cada uma delas corresponde uma das condições básicas sob as quais a vida foi dada ao homem na terra" (ARENDT, 2010, p. 8).

Entre a zoé e a bios politikos, Arendt (2010) identifica, nessa direção, o trabalho, a obra e a ação como atividades essenciais ao ser humano. A primeira delas corresponde ao processo biológico do corpo, ao seu ciclo vital, tal como crescer, alimentar-se, reproduzir, envelhecer e morrer. A atividade do trabalho é uma espécie de resposta imediata ao fenômeno da vida, fenômeno este comum a todos os seres presentes na natureza. $\mathrm{O}$ corpo necessita de água, alimento, abrigo e perpetuação? Então buscamos todos os meios de sobrevivência, produzimos, consumimos e nos saciamos.

Desse modo, o trabalho acompanha a temporalidade do ciclo da existência, não a transcende e está circunscrita ao espaço privado do lar (oikia). É no ambiente privado que nos alimentamos, expelimos os dejetos dos quais o corpo não conseguiu apropriar-se, procriamos, 
crescemos, nos protegemos, iniciamos a criação dos filhos e morremos. Entre as atividades da vita activa, o trabalho é compreendido como aquilo que está mais diretamente ligado ao cumprimento das exigências naturais.

Ainda, no que diz respeito a essa primeira atividade, Arendt (2010) sugere que por não requerer a presença de outros, podendo ser realizada na completa solidão, e por não ser uma atividade exclusivamente humana, ao realizá-la o homem é apenas um animal laborans. Enquanto seres que trabalham e consomem, somos apenas mais uma das espécies animais que povoam a Terra. A vida do animal laborans, dedicada exclusivamente ao trabalho, indica uma completa sujeição corpórea à necessidade, o que corresponde a ser prisioneiro de um ciclo natural inflexível.

Porém, o homem superaria essa condição de animalidade por meio de uma segunda atividade, a obra. A obra ou fabricação (poiésis) é a condição humana da mundanidade. Diante da natureza e de um corpo submetido a um ciclo biológico, a obra permite ao homem estender a sua vida artificializando o mundo e produzindo coisas duráveis que transcendem a sua própria existência.

\begin{abstract}
A obra é a atividade correspondente a não naturalidade da existência humana, que não está engastada no sempre-recorrente ciclo vital da espécie e cuja mortalidade não é compensada por este último. A obra proporciona um mundo "artificial" de coisas, nitidamente diferente de qualquer ambiente natural. Dentro de suas fronteiras é abrigada cada vida individual, embora esse mundo se destine a sobreviver e a transcender todas elas. (ARENDT, 2010, p. 8).
\end{abstract}

Por meio da obra, o homem torna-se uma espécie de flecha lançada verticalmente em uma natureza circular - atravessando-lhe os seus próprios limites temporais e espaciais. De acordo com Arendt (2010), o fabricante de coisas, o Homo faber, não estabelece um metabolismo com a natureza, tal como o animal laborans, mas a viola extraindo materiais para a produção artificial de seu mundo e, ao produzi-lo, o produtor da obra se estende, na obra mesma, para além do seu ciclo de existência. Nesse sentido, a obra estabiliza a vida humana ao permitir aos homens a experiência da durabilidade, possibilitando a percepção daquilo que é idêntico em meio a uma natureza que parece ser heraclitiana.

É interessante observar que o homem, enquanto animal laborans, é um mero consumidor. Ele consome, por exemplo, o alimento, e quando este entra em seu organismo é biologicamente processado: o que lhe serve sustentará seu metabolismo, o que não lhe servir será expelido, mas de qualquer modo esse alimento rapidamente deixará de existir. Em 
contraposição, aquilo que o homem na condição de Homo faber produz não tem valor de consumo, mas de uso. Arendt (2010) cita o exemplo dos sapatos: o uso ou não deles é uma premissa que influencia seu tempo de existência, mas não seu total desaparecimento aos olhos dos homens. Sua presença não é limitada pelo consumo, é um artefato elaborado pelo Homo faber com durabilidade e independência no mundo.

Outra atividade que constitui a vita activa é a ação. A ação, segundo a filósofa, emerge como a terceira condição básica sob a qual a vida foi dada ao homem na Terra.

\begin{abstract}
A ação, única atividade que ocorre diretamente entre os homens, sem a mediação das coisas ou da matéria, corresponde à condição humana da pluralidade, ao fato de que os homens, e não o Homem, vivem na Terra e habitam o mundo. Embora todos os aspectos da condição humana tenham alguma relação com a política, essa pluralidade é especificamente a condição - não apenas a conditio sine qua non, mas a conditio per quam - de toda vida política. (ARENDT, 2010, p. 9).
\end{abstract}

A ação é uma espécie de força imaterial que liga os homens pelo simples estar juntos. É aquilo que permite a conciliação e ao mesmo tempo a distinção dos entes - uma vez que nenhuma pessoa é idêntica à outra, e mesmo nenhum pensamento, sentimento, gosto, desejo, sonho, entre outros. A ação corresponde ao modo de preenchimento dos entre-espaços ou interstícios humanos, os quais caracterizam, de acordo com Arendt (2010), toda a dimensão política. O agir revelaria a identidade dos seres distintos, os modos pelos quais os homens se apresentam uns para os outros, não como objetos físicos, mas como humanos. Com isso, a pensadora realiza uma interpretação fenomenológica do homem, ou seja, em contraposição à mera existência corpórea, a ação é aquilo que nos faz figurar como humanos: "É com palavras e atos que nos inserimos no mundo humano, e essa inserção é como um segundo nascimento, no qual confirmamos e assumimos o fato simples do nosso aparecimento físico original" (ARENDT, 2010, p. 221).

A ação, dessa maneira, não nos é imposta pela necessidade, como o trabalho, nem desencadeada pela utilidade, como a obra. Ela pode ser estimulada pela presença de outros a cuja companhia possamos desejar nos juntar, mas nunca é condicionada por eles, "seu impulso surge do começo que veio ao mundo quando nascemos e ao qual respondemos quando começamos algo novo por nossa própria iniciativa” (ARENDT, 2010, p. 221). Agir, em seu sentido mais geral, significa, então, tomar iniciativa, iniciar, imprimir movimento a alguma coisa, ou ainda fazer emergir. Por meio da ação, o homem seria capaz de fazer surgir, 
a despeito de qualquer determinismo, as novidades no mundo - é aquilo que lhe confere o improvável e o incerto.

O espaço adequado à manifestação do novo ou a prática da liberdade, por sua vez, estão concentrados no domínio público, e é nesse domínio que emerge a dimensão política. Para Arendt (2010), a vida humana deixa de ser frágil e é redimida da mortalidade pela ação, a qual tem como ponto de partida o desejo de estar na companhia de outros, o amor ao mundo e a paixão pela liberdade: "Assim, a língua dos romanos - talvez o povo mais político que conhecemos - empregava como sinônimas as expressões 'viver' e 'estar entre os homens', ou 'morrer' e 'deixar de estar entre os homens"” (ARENDT, 2010, p. 9). Mas a ação também está intimamente ligada ao discurso, pois nela estaria presente a resposta à pergunta: "Quem és?" (ARENDT, 2010, p. 221). Desassociada do discurso, a ação perderia a sua potência reveladora e, em lugar de homens que agem, teríamos autômatos sem almas, executores a realizar coisas que permaneceriam humanamente incompreensíveis. Em outros termos, uma ação sem discurso não diz quem somos, não responde à pergunta “Quem és?”, apresenta somente um corpo emudecido e em movimento.

Dessa forma, por meio da ação o homem alcançaria a estatura de humano, e nela estaria presente a sua dignidade e a possibilidade de uma grandeza radiante. O homem transitaria da zoé para a bios politikos, ou seja, da solidão de um mundo privado à imortalidade memorável, em uma ordem pública na qual sua ação revelaria uma identidade em meio a uma pluralidade. O problema, no entanto, como nos mostra Arendt (2010), é que foi configurado, sobretudo no mundo moderno, um movimento de enfraquecimento da ação. $\mathrm{O}$ homem estaria realizando uma transformação na dinâmica das atividades da vita activa. $\mathrm{O}$ lar (oikia), caracterizado como espaço privado, teria ascendido a espaço público, fazendo surgir um domínio híbrido, a esfera social. Nessa esfera, as questões pertinentes ao espaço privado da família (sexualidade, nascimento, alimentação, crescimento, envelhecimento, saúde, adoecimento, higiene, sanidade e insanidade mental, performance, morte etc.) estariam transformando-se em preocupação coletiva. Prova disso seria o grande interesse dos Estados modernos em regular a vida privada de seus próprios cidadãos - e na atualidade poderíamos comprovar isso observando também o aparecimento de certa "política da vida em si mesma", uma preocupação com "nossas crescentes capacidades de controlar, administrar, projetar, remodelar e modular as próprias capacidades vitais dos seres humanos enquanto criaturas viventes" (ROSE, 2013, p. 16). Em contrapartida, estaria ocorrendo também uma forte imposição dos interesses privados no âmbito da esfera pública, podendo tal fato ser 
comprovado, por exemplo, observando as pressões feitas pelas grandes corporações financeiras sobre decisões políticas, além de certa racionalidade empresarial que estaria servindo como parâmetro para o comportamento social. A modernidade teria trazido consigo

a subordinação e a funcionalização da atividade política pela atividade econômica, a submissão da liberdade à necessidade vital, a substituição da fabricação pelo trabalho, da durabilidade pelo consumo e da ação e do discurso pelos imperativos do comportamento previsível. (DUARTE, 2010, p. 326).

O mundo moderno poderia ser caracterizado, nessa direção, por uma espécie de indistinção entre os domínios público e privado. E o que atestaria essa indistinção, segundo Arendt (2010), seria a vitória contemporânea do animal laborans. Tudo aquilo que era privado e necessário tornou-se assunto político e/ou problema de governo, talvez não de um governo centralizado, mas de uma racionalidade governamental que tende a conduzir em geral as condutas humanas, o que corroboraria o rompimento de uma oposição necessária entre liberdade e vida biológica e sinalizaria uma espécie de empobrecimento da ação humana: "Se compararmos o mundo moderno com o mundo do passado, veremos que a perda da experiência humana acarretada por esse desdobramento é extraordinariamente marcante" (ARENDT, 2010, p. 402).

Nesse contexto biologizante, em que estaria ocorrendo uma espécie de politização da vida biológica, "o próprio pensamento [...] passou a ser uma função do cérebro" (ARENDT, 2010, p. 402), e o sujeito, outrora caracterizado por uma interioridade metafísica, começou a ser identificado com o seu corpo. A base da democracia moderna, diz Agamben (2002, p. 129-130), não é mais o homem livre, "com suas prerrogativas e os seus estatutos, e nem ao menos simplesmente o homo, mas o corpus é o novo sujeito da política". Com isso, a ação estaria perdendo seu potencial revelador da identidade humana e, em contraposição, uma espécie de corpo emudecido que exibe a tonalidade dos músculos, o tamanho das nádegas e a quantidade de silicone nos seios, passariam a identificar o que existe de humano e/ou inumano, normal e anormal no próprio sujeito: "Era justamente esse primado da vida natural sobre a ação política que Arendt fazia, aliás, remontar a transformação e a decadência do espaço público na sociedade moderna" (AGAMBEN, 2002, p. 11).

É importante deixar claro, no entanto, que a busca pela perfectibilidade física, as infinitas possibilidades de transformação pelas tecnologias genéticas, cerebrais, químicas, eletrônicas e mecânicas - e suas próteses - não convertem a bíos simplesmente em zoé, mas 
criam uma espécie de indistinção entre o que é natural e o que é fabricado. Trata-se, assim, de perceber que a política não se limita a qualificar a vida na bios, inserindo o homem no convívio social, mas se orienta para o desnudamento da zoé em uma vida qualificada por seu inqualificável.

Com base nessas reflexões preliminares, pensamos que Arendt (2010) talvez seja uma das principais precursoras de um modo singular de compreender o mundo moderno, segundo o qual, a vida, enquanto fenômeno exclusivamente biológico, teria passado a fazer parte de um cálculo político, científico e econômico. Em outros termos, nascer, viver, reproduzir, morrer, envelhecer, enlouquecer, alimentar, amar, dispor do próprio corpo, modelar, remodelar-se, otimizar as performances, entre outros, tornou-se assunto político, começou a fazer parte dos procedimentos do poder, transformou-se também em interesse de uma racionalidade técnica e econômica. É dentro desse contexto que percebemos a emergência de um interesse particular pelo melhoramento da vida (ROSE, 2013), o culto da performance (EHRENBERG, 2010), o aparecimento de um discurso de maximização do potencial biológico de produção (FOUCAULT, 2008b), e, ainda, uma busca tecnocientífica pela criação de outra condição de existência - uma nova condição humana.

O sucesso da indústria tecnocientífica contemporânea consiste em transformar nossa depressão em Prozac, nossa masculinidade em testosterona, nossa ereção em Viagra, nossa fertilidade ou esterilidade em Pílula, nossa aids em triterapia, sem que seja possível saber quem vem primeiro. (PRECIADO, 2018, p. 37).

Se as questões pertinentes ao fenômeno da vida, próprios ao espaço privado, ascenderam ao âmbito público, resta saber então qual foi a racionalidade, as técnicas, as tecnologias e os procedimentos que promoveram esse acontecimento e, para tratar disso, nos reportaremos a Michel Foucault (2008a, 2008b, 2014, 2015).

\subsection{DO PODER SOBERANO À BIOPOLÍTICA}

Entre as contribuições de Foucault (2014), talvez uma das mais importantes seja a sua habilidade em isolar e conceituar o modo pelo qual o corpo foi enquadrado na operação das relações de poder ${ }^{9}$, principalmente a partir da segunda metade do século XVII. Assim,

\footnotetext{
${ }^{9}$ De acordo com Foucault (2008a, p. 4), "o poder não é uma substância, um fluído, algo que decorreria disto ou daquilo", mas um conjunto de mecanismos e procedimentos que tem por função manter justamente o poder. Trata-se de práticas sociais e/ou de relações constituídas historicamente.
} 
considerando desde esse primeiro período até o século XIX, esse autor constata os fundamentos de um fenômeno que parece essencial para a compreensão da modernidade e da atualidade, isto é, certo "investimento sobre o corpo vivo, sua valorização e a gestão distributiva de suas forças" (FOUCAULT, 2014, p. 152). Trata-se, enfim, do surgimento daquilo que é denominado por esse filósofo de biopoder - o velho direito de causar a morte ou deixar viver, próprio ao exercício de um poder soberano ${ }^{10}$, foi substituído por um poder de “causar a vida ou devolver à morte" (FOUCAULT, 2014, p. 149). De outro modo, no lugar ou em complemento a um modelo jurídico-político que caracterizava o exercício do poder até então, Foucault (2014) percebe a emergência de uma nova forma de ação governamental que não está mais relacionada apenas à lei ou à repressão, que não viola abertamente os indivíduos ou, simplesmente, que faz morrer ou deixa viver, como era no período da soberania, mas um uso do poder que é positivo, produtivo, transformador e que potencializa a vida em vez de subtraí-la: "o direito de morte tenderá a se deslocar ou, pelo menos, a se apoiar nas exigências de um poder que gere a vida e a se ordenar em função de seus reclamos" (FOUCAULT, 2014, p. 147).

Assim, por volta dos séculos XVII e XVIII, surgiram e foram desenvolvidas, num primeiro momento, técnicas e mecanismos de biopoder essencialmente centradas no corpo dos indivíduos, mecanismos voltados para organizar os corpos individuais espacialmente, vigiá-los e aumentar-lhes a força útil e produtiva: "o soldado se tornou algo que se fabrica; de uma massa informe, de um corpo inapto, fez-se a máquina de que se precisa; corrigiram-se aos poucos as posturas: lentamente uma coação calculada percorre cada parte do corpo, assenhoreia-se dele" (FOUCAULT, 2013d, p. 131). Nessa mesma direção, foram aperfeiçoadas e aplicadas técnicas anátomo-políticas ou disciplinares sobre o corpo dos indivíduos nos espaços escolares, nas fábricas, hospitais, ateliês etc. Essas técnicas, de maneira geral, esquadrinharam os indivíduos, restringiram a movimentação dos corpos e, ao recompô-los, aumentaram o seu potencial de produtividade.

Além das tecnologias disciplinares, Foucault (2014, p. 150) aponta também para uma segunda forma de biopoder que não excluí a técnica disciplinar, mas que a integra e a complementa, e se dirige não ao homem-máquina, mas ao homem-espécie: “centrou-se no corpo-espécie, no corpo transpassado pela mecânica do ser vivo e como suporte dos processos

\footnotetext{
${ }^{10} \mathrm{O}$ governo soberano consiste em uma espécie de ação administrativa da morte. O poder está literal e publicamente inscrito no corpo de seus súditos. Ele pode a qualquer momento subtrair a vida; assim, no direito de matar é que o soberano possuí o direito sobre a vida: "o poder era, antes de tudo, nesse tipo de sociedade, direito de apreensão das coisas, do tempo, dos corpos, da vida” (FOUCAULT, 2014, p. 146).
} 
biológicos". Essa nova tecnologia de poder é aquilo que o autor denomina de biopolítica, "a proliferação, os nascimentos e a mortalidade, o nível de saúde, a duração da vida, a longevidade [...]; tais processos são assumidos mediante toda uma série de intervenções e controles reguladores: uma biopolítica da população" (FOUCAULT, 2014, p. 150). O que aconteceu então foi que os fenômenos relacionados à vida humana, e a própria vida, começaram a ser levados em conta por mecanismos de saber e poder e tornaram-se motivos de controle e modificação.

O homem ocidental aprende, pouco a pouco, o que é ser uma espécie viva num mundo vivo, ter um corpo, condições de existência, probabilidade de vida, saúde individual e coletiva, forças que se podem modificar, e um espaço em que se pode reparti-las de modo ótimo. Pela primeira vez na história, sem dúvida, o biológico reflete-se no político. (FOUCAULT, 2014, p. 154).

Exemplificando o deslocamento do poder disciplinar para a biopolítica, Foucault (2005) elucida que a partir de meados do século XVIII a doença, enquanto simples causa da morte dos indivíduos, passou a ser compreendida como um fenômeno de população, uma endemia cuja subtração das forças sociais, diminuição do tempo de trabalho e custos econômicos começaram a ser matematicamente analisados. Em vez de uma medicina voltada exclusivamente para a cura do indivíduo, com a biopolítica surge outra, que vai ter a função maior de higiene pública "com organismos de coordenação dos tratamentos médicos, de centralização da informação, de normalização do saber, e que adquire também o aspecto de campanha de aprendizado da higiene e de medicalização da população" (FOUCAULT, 2005, p. 291). Assim, segundo Foucault (2014), se pudéssemos chamar de "bio-história" o entrelaçamento, as pressões e as interferências dos movimentos da vida com os processos da história, “deveríamos falar de 'biopolítica' para designar o que faz com que a vida e seus mecanismos entrem no domínio dos cálculos explícitos, e faz do poder-saber um agente de transformação da vida humana" (FOUCAULT, 2014, p. 154).

Com uma política voltada para a administração das populações, e com a ajuda de novos instrumentos ${ }^{11}$ de análise, como a estatística e os estudos demográficos, eventos como

\footnotetext{
${ }^{11}$ Nos mecanismos implantados pela biopolítica, vai tratar-se sobretudo, é claro, de previsões, de estimativas estatísticas, de medições globais; vai tratar-se, igualmente, não de modificar tal fenômeno em especial, não tanto tal indivíduo, na medida em que é indivíduo, mas, essencialmente, de intervir no nível daquilo que são as determinações desses fenômenos gerais, desses fenômenos no que eles têm de global. Vai ser preciso modificar, baixar a morbidade; vai ser preciso encompridar a vida; vai ser preciso estimular a natalidade (FOUCAULT, 2005, p. 293).
} 
suicídio, criminalidade, delinquência, mortalidade, escassez de alimento, circulação de doenças, entre outros, puderam ser enquadrados em curvas ou padrões de normalidade e serem assistidos pelas forças estatais. Configuraram-se, desse modo, desde o século XVII, técnicas e procedimentos de poder - uma anátomo-política do corpo e uma biopolítica da população - por meio dos quais se nota um deslocamento de práticas e também de uma racionalidade política que administrava a morte (soberania) para uma outra que se dirige agora para a compreensão, modificação, previsão, potencialização e controle da vida: “Já não se trata de pôr a morte em ação no campo da soberania, mas de distribuir os vivos em um domínio de valor e utilidade. Um poder dessa natureza tem que medir, avaliar, hierarquizar" (FOUCAULT, 2014, p. 155-156). Assim, o homem "durante milênios, permaneceu o que era para Aristóteles um animal vivo e, além disso, capaz de existência política; o homem moderno é um animal em cuja política sua vida de ser vivo está em questão" (FOUCAULT, 2014, p. 155).

Voltando-nos agora mais especificamente para a biopolítica - conceito que foi apresentado preliminarmente no volume I de História da sexualidade e no curso "Em defesa da sociedade" -, o como do seu exercício, o seu modus operandi, parece só ter sido detalhado nos cursos "Segurança, território e população" e "Nascimento da biopolítica". São nesses cursos que emergem noções como as de dispositivos de seguridade, governamentalidade e teoria do capital humano, os quais possibilitaram uma compreensão mais apurada dos modos de condução moderna da vida, em especial esclareceram as formas de implemento da ação administrativa de governo da população e apontaram as técnicas de governamento, sobretudo as de tipo liberal e neoliberal.

A palavra "securité", como nos mostra Foucault (2008b, p. 10), remete, entre outras coisas, à segurança policial - atividade que se encarrega "dos indivíduos até em seu mais tênue grão" -, ao sistema diplomático-militar, à manutenção da soberania, ao controle sociopolítico e também à seguridade social. Trata-se, de maneira geral, da gestão da população em seus mínimos detalhes e regularidades. Assim, temos que os dispositivos de segurança consistem nas várias práticas que permitem governar uma cidade - dizem respeito ao planejamento de toda e qualquer circulação que ocorre dentro de um espaço territorial (FOUCAULT, 2008a). 
Para oferecer inteligibilidade aos dispositivos de seguridade, Foucault (2008a) apresenta alguns exemplos interessantes, entre eles uma reflexão sobre a resolução de um mesmo problema em diferentes contextos de exercício do poder (soberania, disciplina e biopolítica). Assim, é posto o problema: Como tratar ou punir alguém que transgrediu uma lei do tipo "não matarás, não roubarás" (FOUCAULT, 2008a, p. 6)? Ao observar as práticas de governo do poder soberano, o autor percebe que diante do problema da criminalidade as formas de punição correspondiam, em geral, ao enforcamento, ao desterro ou a multa. Já no contexto disciplinar o foco inicial não era propriamente na transgressão, mas em sua previsão. Para isso, vigilâncias e controles eram desenvolvidos, mas se por alguma razão essas técnicas de prevenção não funcionassem, era imposto ao culpado uma série de exercícios e trabalhos correcionais mediante técnicas penitenciárias. Por último, no contexto da biopolítica, e independentemente da punição, da previsão e da correção, Foucault constata que o que efetivamente é colocado no centro dos interesses da ação governamental são as respostas a uma série de questões estratégicas, tais como: Qual é a taxa média desse tipo de criminalidade? As punições rigorosas ou brandas modificam esse índice? Quanto custa a repressão a essas transgressões? É possível reeducar o criminoso? "O que é melhor, relaxar um pouco com o roubo ou relaxar um pouco com a repressão" (FOUCAULT, 2008a, p. 8). As respostas a essas questões teriam guiado, desde o século XVIII, o modo de operação da ação governamental, por meio delas teria sido possível "manter um tipo de criminalidade, ou seja, o roubo, dentro de limites [...] economicamente aceitáveis e em torno de uma média que vai ser considerada, digamos, ótima para um funcionamento social dado" (FOUCAULT, 2008a, p. 8).

Dessa maneira, no contexto da análise, a "solução" para a criminalidade é apresentada por diferentes práticas e formas de racionalidade, isto é, enquanto no exercício do poder soberano a punição é feita de maneira severa, podendo corresponder à própria subtração da vida, e no poder disciplinar a punição sugere um isolamento, uma concentração e um fechamento dos espaços em volta do criminoso, com a biopolítica o crime é inserido em um conjunto de acontecimentos prováveis, calculando-se o custo da ação do poder e instaurandose os limites do aceitável. A estratégia da ação governamental, então, passa pela admissão de que o crime é um acontecimento natural, possuí regularidade, curva de normalidade e seu controle está sujeito a um cálculo econômico.

No entanto, ao tratar como natural aquilo que anteriormente era considerado do ponto de vista valorativo, um "mal" que deveria ser evitado, no lugar de propor um controle rígido, 
o que os poderes estatais procuraram fazer foi compreendê-lo em sua realidade física e sugerir medidas de segurança.

Vocês veem ao mesmo tempo que esse postulado, quero dizer esse princípio fundamental, de que a técnica política nunca deve descolar do jogo da realidade consigo mesma, é profundamente ligado ao princípio geral do que se chama liberalismo. O liberalismo, o jogo: deixar as pessoas fazerem, as coisas passarem, as coisas andarem, laisser-faire, laisser-passer e laisseraller, quer dizer, essencial e fundamentalmente, fazer de maneira que a realidade se desenvolva e vá, siga seu caminho, de acordo com as leis, os princípios e os mecanismos que são os da realidade mesma (FOUCAULT, 2008a, p. 62-63).

Nessa direção, com base em uma nova prática governamental, foi possível fixar um limite de normalidade/naturalidade para os eventos populacionais. Os dispositivos de seguridade compreendiam, assim, um conjunto de procedimentos governamentais liberais que emergiu, principalmente a partir do século XVIII, voltado para os acontecimentos do "corpoespécie”. Em suma, enquanto o poder disciplinar, por meio de uma microfísica, regula e potencializa o corpo dos indivíduos, os dispositivos de seguridade administram os fenômenos regulares e/ou normais da população: criminalidade, escassez de alimento, taxas de natalidade, mortalidade etc. Então o problema estratégico que esses dispositivos colocam é o de como manipular as diferentes distribuições de normalidade, umas em relação às outras, e maximizar as mais favoráveis.

A análise desses dispositivos de seguridade foi importante para Foucault (2008a), porque lhe permitiu perceber os problemas específicos da população e, ao olhar diretamente para eles, foi remetido rapidamente para a questão do governo e da governamentalidade. Para tratar desse tema, o filósofo retomou novamente a análise comparativa entre o governo soberano e o modelo moderno de governo da vida, mas dessa vez enfatizando uma mutação específica na maneira de governar. O fenômeno da governamentalidade teria surgido, segundo o autor, pelo deslocamento de uma modalidade própria de governar, que consistia em aconselhar os Príncipes $^{12}$ para uma arte de governar e para uma ciência política. Esse deslocamento teria ocorrido a partir do século XVI, sendo compreendido, em linhas gerais,

\footnotetext{
${ }^{12}$ Segundo Foucault (2008a), diferente da maneira com que Nicolau Maquiavel sugere o governo do Príncipe, o qual acontece de forma monocrática, consistindo na manutenção de seu território e na submissão de seus súditos - apresentando um tratado de habilidades do príncipe na manutenção de seu principado, alheio a quaisquer outras formas de governo dentro do próprio território -, a arte de governar que emerge no século XVI propõe, de início, que no interior de um mesmo Estado existe uma pluralidade de governos e governantes, como o governo da casa, das crianças, das almas, de uma província, de uma família etc. Nessa pluralidade, o Príncipe seria apenas uma das modalidades e deveria coexistir em uma relação de continuidade com as outras, com o pai de família, o pedagogo, o sacerdote, o magistrado etc.
} 
como um alargamento para todo o corpo social das práticas de governo construídas originalmente no interior das instituições religiosas ${ }^{13}$. Uma das principais características dessa prática consistiria em cuidar dos indivíduos, dos detalhes de sua vida, de forma minuciosa.

Até o século XVI, como afirma Foucault (2008a), as artes de governar estiveram presas a um modelo econômico familiar que as bloqueavam - em que governar era o mesmo que gerir o lar -, mas a partir do século XVII elas começaram a ser pensadas em estruturas institucionais mais amplas, o que ocasionou o seu desbloqueio, principalmente quando os Estados tomaram como objeto precípuo não a unidade do território, mas os detalhes e a complexidade da população: “A constituição de um saber de governo é absolutamente indissociável da constituição de um saber de todos os processos da população, no sentido lato, o que se chama precisamente "economia"' (FOUCAULT, 2008a, p. 140). O principal fator técnico desse desbloqueio teria sido o uso de estatísticas como ferramentas de decifração da dinâmica populacional. Essa dinâmica permitiu mostrar que a população estava submetida a regularidades próprias, como número de mortes, doenças, acidentes, crimes etc. Possibilitou notar também que existiam fenômenos que não podiam ser simplesmente reduzidos à grade de inteligibilidade familiar, tais como as epidemias, as expansões endêmicas, a espiral do trabalho e da riqueza, e, mais, provou que o comportamento da população produzia efeitos econômicos.

Assim, de modelo para a arte de governar, a família passou para um segundo plano, transformou-se em instrumento para o governo da população: "ela é um segmento simplesmente privilegiado porque, quando se quiser obter alguma coisa da população quanto ao comportamento sexual, quanto à demografia, ao número de filhos, quanto ao consumo, é bem através da família que isso deverá passar" (FOUCAULT, 2008a, p. 139). Outro fator importante para o desbloqueio da governamentalidade teria sido o deslocamento da população de mero meio para o exercício da soberania, para a finalidade última e o instrumento do próprio governo. “Qual seria o objetivo do governo?”, pergunta Foucault, “certamente, não o de governar, mas o de melhorar o destino das populações, de aumentar as suas riquezas, sua duração de vida, ou sua saúde" (FOUCAULT, 2008a, p. 140, grifo nosso). A importante questão que está sendo colocada, então, é sobre a possibilidade de se interferir no destino biológico da própria população, ou seja: otimizar a vida, diminuir a morbidade, administrar a natalidade, melhorar a expectativa e a qualidade de vida, combater e prevenir doenças etc. Trata-se, enfim, de uma espécie de estatização do biológico, “a população vai ser

\footnotetext{
${ }^{13}$ Trata-se do poder pastoral, em que o rei, Deus ou o chefe seja um pastor em relação aos homens, que são como seu rebanho.
} 
o objeto que o governo deverá levar em conta nas suas observações, em seu saber, para chegar a definitivamente governar de maneira racional e refletida" (FOUCAULT, 2008a, p. 140). A população figura, desse modo, como sujeito das necessidades, das aspirações, "mas também como objeto entre as mãos do governo, consciente diante do governo, do que ela quer, e inconsciente também do que lhe fazem fazer" (FOUCAULT, 2008a, p. 293). Com isso, ao ser desbloqueada, a arte de governar dirige-se para a administração dos interesses populacionais, admitindo até mesmo a possibilidade de fomentá-los.

Se, por um lado, o efetivo exercício do poder, em especial a partir da segunda metade do século XVIII, é informado pelas técnicas de condução da população, ele também acabará por oferecer ocasião para uma elaboração conceitual. De outro modo, a constituição de um saber de governo será inseparável da constituição de um saber de todos os processos que giram em torno da população, isto é, de uma "economia política" (FOUCAULT, 2008a, p. 100). Ao enfatizar o surgimento da população e da economia política, Foucault (2008a) demarca a passagem das artes de governar para a ciência política, das estruturas da soberania para as estruturas de governo. Entrementes, apesar dessa demarcação, o autor observa que a soberania e a disciplina não cessaram de desempenhar seus papéis, apenas foram reposicionadas na gestão da população, principalmente no que tange ao cuidado com os mínimos detalhes da vida. Governar a população sob o signo de uma ciência política não quer dizer então gerir simplesmente a massa coletiva dos fenômenos, ou geri-la no nível de seus resultados globais, mas significa poder geri-la em profundidade, fineza e no detalhe. Assim,

Por "governamentalidade", entendo o conjunto constituído pelas instituições, procedimentos, análises e reflexões, cálculos e táticas que permitem exercer essa forma bem específica, bem complexa, de poder, que tem como alvo principal a população, como forma mais importante de saber, a economia política, como instrumento técnico essencial, os dispositivos de segurança. Em segundo lugar, por "governamentalidade", entendo a tendência, a linha de força que, em todo o Ocidente, não cessou de conduzir, e há muitíssimo tempo, em direção à preeminência desse tipo de saber que se pode chamar de "governo" sobre todos os outros: soberania, disciplina. Isto, por um lado, levou ao desenvolvimento de toda uma série de aparelhos específicos de governo e, por outro, ao desenvolvimento de toda uma série de saberes. Enfim, por "governamentalidade", acho que se deveria entender o processo, ou melhor, o resultado dos processos pelo qual o Estado de Justiça da Idade Média, tornado nos séculos XV e XVI Estado administrativo, encontrou-se, pouco a pouco, "governamentalizado". (FOUCAULT, 2008a, p. 143-144).

\subsection{GOVERNAMENTALIDADE LIBERAL}


No curso "Nascimento da biopolítica", Foucault (2008b, p. 26) nota que as principais questões relacionadas à atividade de governar deslocaram-se, com o tempo, do problema da conformidade governamental, específico da Idade Média - “será que governo de acordo com as leis morais, naturais, divinas, etc.?”-, passando, entre os séculos XVI e XVII, por questões próprias a uma razão de Estado $^{14}$ - "será que governo bastante bem, [...] com bastantes detalhes para levar o Estado a um ponto estabelecido por seu dever-ser, para levar o Estado ao seu máximo de força?” (FOUCAULT, 2008b, p. 26) - até o problema do excesso de governo, específico de uma racionalidade liberal ${ }^{15}$ - "será que governo bem no limite desse demais e desse pouco demais, entre esse máximo e esse mínimo que a natureza das coisas fixa para mim, quero dizer, as necessidades intrínsecas às operações de governo?” (FOUCAULT, 2008b, p. 27). De outro modo, o autor constata uma espécie de mutação da razão governamental, sendo um dos principais fatores para isso certa mudança no princípio de limitação da arte de governar.

Se nos séculos XVI e XVII - mesmo com as ações policialescas que regulamentavam quase todas as atividades dos súditos -, o direito se impôs como princípio externo ${ }^{16}$ limitador da razão de Estado, principalmente em relação ao problema da legitimidade e ilegitimidade das ações governamentais, no século XVIII ele vai ser substituído por outro princípio que se mostrará intrínseco à própria arte de governar, isto é, será substituído pela economia política ${ }^{17}$. Com essa mudança teria surgido uma nova racionalidade, uma nova arte de governar, chamada por Foucault (2008b, p. 17-18) de "razão governamental crítica", a qual, em vez de questionar a legitimidade ou ilegitimidade das ações de governo, "vai girar em torno de como não governar demais". Trata-se, de modo geral, da inserção de uma concepção pragmática na teorização da ação governamental.

\footnotetext{
${ }^{14}$ A razão de Estado, originada no século XVI, diz respeito a uma racionalidade governamental que busca no exercício e no reforço do Estado a legitimação de uma governamentalidade crescente e a regulamentação de seu desenvolvimento, "é precisamente uma prática, ou antes, uma racionalização de uma prática que vai se situar entre um Estado apresentado dado e um Estado como a construir e edificar" (FOUCAULT, 2008b, p. 6).

${ }^{15} \mathrm{O}$ liberalismo é tomado por Foucault (2008b) no contexto de uma genealogia da governamentalidade; é mais que uma doutrina econômica, uma técnica de governo que é capaz de constituir o próprio Estado.

${ }^{16}$ Externo porque os limites que se procura pôr a razão de Estado vêm de Deus ou foram formulados em uma história remota, isso "quer dizer também que eles possuem um funcionamento de certo modo puramente limitativo, dramático, pois, no fundo, só se objetará o direito à razão de Estado quando a razão de Estado houver ultrapassado esses limites de direito, e é nesse momento que o direito poderá definir o governo como ilegítimo, poderá lhe objetar suas usurpações e, finalmente, até mesmo liberar os súditos do seu dever de obediência" (FOUCAULT, 2008b, p. 14).

${ }^{17}$ Por economia política entende-se "um método de governo capaz de assegurar a prosperidade de uma nação" ou, resgatando a Enciclopédia, de Jean-Jacques Rousseau, "significa uma espécie de reflexão geral sobre a organização, a distribuição e a limitação dos poderes numa sociedade". No entanto, Foucault declara que a economia política "é fundamentalmente o que possibilitou assegurar a autolimitação da razão governamental" (FOUCAULT, 2008b, p. 19).
} 
A economia política reflete sobre as próprias práticas governamentais, e essas práticas governamentais ela não as interroga em termos de direito para saber se são legítimas ou não. Ela as encara não do lado de suas origens, mas do lado de seus efeitos, não se perguntando, por exemplo: "o que é que autoriza um soberano a cobrar um imposto?", mas simplesmente: "quando se cobra um imposto, quando se cobra esse imposto nesse momento dado, de tal categoria de pessoas ou de tal categoria de mercadorias, o que vai acontecer?". Pouco importa ser esse direito legítimo ou não, o problema é saber quais os efeitos ele tem e se esses efeitos são negativos. (FOUCAULT, 2008b, p. 20-21).

Ademais, o governante passa a respeitar certa "natureza" dos fenômenos sociais, presente até mesmo na própria ação governamental. A noção de natureza evocará, em suma, o conhecimento das coisas sobre as quais o poder do Estado deverá manifestar-se e os instrumentos mais adequados que deverão ser usados para alcançar os efeitos desejados. A economia política, enquanto racionalidade governamental autolimitativa, ao permitir a descoberta dessa naturalidade, deixa de tipificar a ação governamental como legítima ou ilegítima e começa a medir as condições mais favoráveis para o seu sucesso. Com isso, a arte de governar passará a ser regida por um "princípio de verdade” (FOUCAULT, 2008b, p. 24), pois "o maior mal de um governo, o que faz que ele seja ruim, não é o príncipe ser ruim, é ele ser ignorante" (FOUCAULT, 2008b, p. 23). Ocorre, desse modo, uma reconfiguração nas relações de poder, em que a partilha entre o verdadeiro e o falso será o ponto definidor dos critérios para julgar as ações políticas. Foucault (2008b), entretanto, adverte que isso não seria o reinado da verdade na política, mas o regime de verdade que é característico precisamente do que se pode chamar de era da política. E, a partir do momento em que a política é medida por essa verdade, não uma verdade da política, mas uma verdade com a qual a política tem de se haver, é instaurado o liberalismo.

Quando digo regime de verdade, não quero dizer que a política ou a arte de governar, por assim dizer, finalmente, alcança nessa época a racionalidade. Não quero dizer que se atingiu nesse momento uma espécie de limiar epistemológico a partir do qual a arte de governar poderia se tornar científica. Quero dizer que esse momento que procuro indicar atualmente, que esse momento marcado pela articulação, numa série de práticas, de um certo tipo de discurso que, de um lado, o constitui como um conjunto ligado por um vínculo inteligível e, de outro lado, legisla e pode legislar sobre essas práticas em termos de verdadeiro ou falso. (FOUCAULT, 2008b, p. 25).

O liberalismo marca um novo momento político e, mais do que uma doutrina econômica, configura-se como uma técnica de governo da vida, constituindo o próprio 
Estado. De acordo com Foucault (2008b), o princípio regulador dessa nova arte de governar é o mercado, uma vez que é nesse espaço que emerge os regimes de verdade. Entretanto, esse filósofo chama atenção para o fato de que isso nem sempre teria sido assim. Até o século XVII, o mercado era visto como um espaço de jurisdição das práticas de governo, isto é, o lugar cujo principal objetivo era o de estabelecer o preço justo. No entanto, a partir do surgimento de uma razão crítica governamental, ou paralelamente a ela, o mercado passou a ser visto como um espaço regido por leis próprias cuja naturalidade deveria ser observada e respeitada: "O mercado é que vai fazer que o bom governo já não seja somente um governo justo. O mercado é que vai fazer que o governo, agora para ser um bom governo, funcione com base na verdade" (FOUCAULT, 2008b, p. 45). Nesse processo de mutação, a principal contribuição da economia política vai ser a de demonstrar que o mercado é o grande revelador da verdade. De modo geral, ele não diz ao governo qual é a melhor conduta a ser seguida, mas indica a direção para a qual o governo deve olhar para encontrar o princípio de verdade de sua prática governamental. A partir daí as ações governamentais passaram a levar em conta os testemunhos oferecidos pela análise econômica do mercado e o interesse próprio dos indivíduos, "os interesses são, no fundo, aquilo por intermédio do que o governo pode agir sobre todas estas coisas que são, para ele, os indivíduos, os atos, as palavras, as riquezas, os recursos, a propriedade, os direitos, etc.” (FOUCAULT, 2008b, p. 61).

\subsubsection{Governamentalidade neoliberal e teoria do capital humano}

De outro lado, para Foucault (2008b), diferentemente do liberalismo do século XVIII, do tipo Adam Smith, o problema do neoliberalismo não será essencialmente saber como fazer um arranjo no interior de uma sociedade para daí produzir um espaço livre para o mercado, mas, ao contrário, "saber como se pode regular o exercício global do poder político com base nos princípios de uma economia de mercado" (FOUCAULT, 2008b, p. 181). Enquanto no liberalismo o problema era evitar os excessos da ação governamental, estabelecendo a liberdade econômica dentro de uma sociedade composta de instituições regulamentadas, no neoliberalismo o objetivo será o de fazer existir o Estado e, ao mesmo tempo, regulamentar a própria sociedade por meio de um elemento não estatal.

[...] o governo neoliberal não tem de corrigir os efeitos destruidores do mercado sobre a sociedade. Ele não tem de constituir, de certo modo, um contraponto ou um anteparo entre a sociedade e os processos econômicos. 
Ele tem de intervir sobre a própria sociedade em sua trama e em sua espessura. No fundo, ele tem de intervir nessa sociedade para que os mecanismos concorrenciais, a cada instante e em cada ponto da espessura social, possam ter o papel de reguladores. (FOUCAULT, 2008b, p. 199).

Assim, uma das principais novidades do neoliberalismo é a introdução da regulação do mercado - entendido não como um espaço de trocas, mas enquanto mecanismos de concorrência, ou simplesmente como princípio regulador da sociedade. Nesse contexto, o que é buscado por meio desses mecanismos concorrenciais não é uma sociedade submetida ao "efeito-mercadoria", tal como no liberalismo clássico, mas uma sociedade empresarial: "O homo oeconomicus que se quer reconstituir não é o homem da troca, não é o homem consumidor, é o homem da empresa e da produção" (FOUCAULT, 2008b, p. 201). Com isso, o neoliberalismo instala, em especial na Europa do pós-guerra, uma Vitalpolitik, ou, mais propriamente, uma política empresarial da vida, a qual se multiplicará no interior do corpo social. Trata-se de fazer do mercado, da concorrência e, por conseguinte, da empresa, o que é chamado de poder informador da sociedade (FOUCAULT, 2008b).

Essa reflexão é desenvolvida com base em uma análise do neoliberalismo alemão, ou ordoliberalismo, e também no neoliberalismo francês, os quais apresentam como questãochave a preocupação com um modo de organizar o Estado colocando-o sob o signo de uma vigilância do mercado. Porém, diferentemente do que aconteceu na Alemanha e na França, onde o neoliberalismo foi formulado pelos governantes enquanto opção econômica e política, nos Estados Unidos, segundo Foucault (2008b, p. 301), ele teria se constituído como uma maneira de ser e também como "um método de pensamento, uma grade de análise econômica e sociológica". A teoria do capital humano surge - ou é percebida - em resposta à aplicação dessa grade de análise econômica e pela reinterpretação em termos estritamente econômicos de um campo que era considerado até então como não econômico. Para provar isso, Foucault (2008b) aponta para a incursão dessa análise em uma atividade que, segundo os teóricos neoliberais, estava excluída de uma inteligibilidade econômica. Essa atividade seria o próprio trabalho.

De modo geral, o trabalho teria sido concebido pelos economistas clássicos, e até mesmo por Marx, por uma ótica bastante abstrata e quantitativa. Abstrato, "isto é, o trabalho concreto transformado em força de trabalho, medido pelo tempo, posto no mercado e retribuído como salário não é o trabalho concreto" (FOUCAULT, 2008b, p. 305). E, quantitativo, porque era excluído do trabalho "toda a sua realidade humana e todas as suas variáveis qualitativas" (FOUCAULT, 2008b, p. 305). Ao analisar o trabalho, o liberalismo 
clássico teria enfatizado diferentes variáveis da lógica de produção, como o tempo e a força, e, no entanto, teria deixado de lado tudo aquilo que não se encaixava na formalidade fria dessa lógica, isto é, desconsiderava as características dos principais agentes envolvidos, os próprios trabalhadores. Coube, então, aos neoliberais, particularmente em sua versão americana, restituir à atividade do trabalho aquilo que lhe fora amputado pela lógica do liberalismo. Assim, ao transferir o foco de sua análise para os teóricos da Escola de Chicago ${ }^{18}$, especialmente Theodore Schultz e Gary Baker, Foucault (2008b) percebe uma espécie de mutação epistemológica da análise econômica.

Praticamente, a análise econômica de Adam Smith, até o início do século $\mathrm{XX}$, tinha, como objeto, grosso modo, o estudo dos mecanismos de produção, dos mecanismos de troca e dos fatos de consumo no interior de uma estrutura social dada, com as interferências desses três mecanismos. Ora, para os neoliberais, a análise econômica deve consistir não no estudo desses mecanismos, mas no estudo da natureza e das consequências do que chamam de opções substituíveis, isto é, o estudo e a análise da maneira como são alocados recursos raros para fins que são concorrentes, isto é, para fins que são alternativos, que não podem se superpor uns aos outros. (FOUCAULT, 2008b, p. 307).

Em que consiste então essa mutação epistemológica ou, de certa forma, essa virada copernicana da análise neoliberal? No que tange a uma reinterpretação econômica da atividade do trabalho, o problema colocado não se referirá mais, afirma Foucault (2008b), ao valor com o qual se compra o trabalho, ou ao que ele produz tecnicamente, ou ainda ao valor que o tempo de trabalho acrescenta ao produto, mas, sobretudo, se esforçará em saber como quem trabalha utiliza os recursos de que dispõe. Desse modo, em vez de a economia dirigir a sua análise para o mecanismo relacional entre coisas e processos - do gênero capital, investimento, produção -, tomará o comportamento humano como uma relação entre fins e meios raros que tem usos mutuamente excludentes. Ao reintroduzir o trabalho no campo da análise econômica, os neoliberais o situarão então do ponto de vista de quem trabalha: "será preciso estudar o trabalho como conduta econômica praticada, aplicada, racionalizada, calculada por quem trabalha" (FOUCAULT, 2008b, p. 307).

A consequência disso é que o trabalhador deixará de ser um objeto de oferta e de procura na forma de força de trabalho e se tornará um sujeito econômico ativo. Afinal,

\footnotetext{
${ }^{18}$ Berço do pensamento neoliberal, desenvolveu-se principalmente depois da segunda metade do século XX. No período pós-guerra, os economistas da Escola de Chicago trataram de atacar as bases da economia americana fundamentadas na intervenção estatal da economia, como o New Deal e o Plano Marshall.
} 
pergunta Foucault (2008b), por que as pessoas trabalham? Recorrendo a Schultz e Becker, o próprio filósofo responde: para a obtenção de um salário que pode ser compreendido como uma renda. Em contraposição, assumindo uma definição de renda datada do início do século XX, construída por Irving Fisher, os neoliberais a admitirão como o produto de um capital e, ainda, chamarão de capital tudo aquilo que é fonte de uma renda futura. Seguindo essa lógica, os neoliberais definem o salário como a renda de um capital. Mas de qual capital o salário seria uma renda?

Pois bem, é o conjunto de todos os fatores físicos e psicológicos que tornam uma pessoa capaz de ganhar este ou aquele salário, de sorte que, visto do lado do trabalhador, o trabalho não é uma mercadoria reduzida por abstração à força de trabalho e ao tempo (durante) o qual ela é utilizada. (FOUCAULT, 2008b, p. 308).

Nesses termos, a economia política passa a ter como objeto o comportamento humano e a racionalidade interna que o anima: "Trata-se de estudar o trabalho exercido pelos indivíduos como uma conduta econômica, e de tentar entender como essa conduta é praticada, racionalizada e calculada por aquele que a exerce" (GADELHA, 2009, p. 176). Outra consequência dessa reinterpretação econômica do trabalho, feita pelos teóricos da Escola de Chicago, é que a competência do trabalho não é mais separada de quem é competente para realizá-lo, ou seja, admite-se que não se deve separar o indivíduo do capital. Com isso, as competências, as habilidades e as aptidões dos indivíduos passam a constituir o seu próprio capital, e por meio delas é que serão produzidos seus fluxos de renda. Fluxos, porque a capacidade de produção do indivíduo não é constante, "tem sua duração de vida, sua duração de utilizabilidade, tem sua obsolescência, tem seu envelhecimento" (FOUCAULT, 2008b, p. 309). Então, dentro dessa nova dinâmica, o indivíduo será movido a fazer investimentos em si mesmo, pois quanto maior for o conjunto de suas competências, habilidades e aptidões, maior também será a expectativa do seu fluxo de renda.

Desse modo, ao usar a grade de inteligibilidade econômica para interpretar o trabalho, ocorre um fenômeno bastante interessante e singular: o trabalhador transforma-se em uma espécie de empresa de si mesmo. Se na economia de mercado concorrencial, tal como apontado pelo ordoliberalismo, a unidade fundamental de decifração é a empresa, na sociedade vista sob a ótica do neoliberalismo americano, a unidade base de interpretação será o indivíduo trabalhador, ou, mais propriamente, o trabalhador-empresa. Esse processo vai corresponder ao retorno a um homo oeconomicus, mas não enquanto parceiro da troca, tal como na concepção clássica, e sim como "empresário de si mesmo, sendo ele próprio seu 
capital, sendo para si mesmo seu produtor, sendo para si mesmo a fonte de (sua) renda" (FOUCAULT, 2008b, p. 311). Como consequência desse novo homo oeconomicus, a análise econômica se deslocará de sua preocupação tradicional com a lógica histórica de processos ligados à produção para a maneira como os indivíduos constituem e acumulam o seu próprio capital, o capital humano. Desse modo, de acordo com Foucault (2008b), aos olhos dos teóricos neoliberais esse capital será composto de dois tipos de elementos: os inatos e os adquiridos.

Os primeiros correspondem às características genéticas dos indivíduos, que ao serem conhecidas possibilitam aos especialistas apurar os riscos e seus tipos envolvendo cada indivíduo ao longo de sua existência. De outra forma, é aquilo que permite determinar quem são as pessoas que, mesmo aparentemente saudáveis e "normais", podem vir a adquirir uma doença no futuro. Em consequência desse reconhecimento, o próprio mecanismo da produção de filhos começará a fazer parte de um cálculo econômico e social: evita-se a união entre indivíduos de risco, entre aqueles que possuem um capital genético "defeituoso", e é estimulada a união entre as pessoas que são dotadas de um "bom” capital genético. Trata-se, então, de promover um mapeamento das matrizes raras que devem entrar no cálculo dos investimentos econômicos alternativos, ao mesmo tempo em que se evitam os "desvios". Segundo Foucault (2008b, p. 314), isso não seria uma evocação do racismo, pelo menos em termos tradicionais, senão "em termos de constituição, de crescimento, de acumulação e de melhoria do capital humano".

Outro modo de pensar na melhoria do capital humano, a despeito do elemento inato e/ou genético, é por meio de investimentos educacionais, é muito mais do lado do adquirido, ou seja, "da constituição mais ou menos voluntária de um capital humano no curso da vida dos indivíduos, que se colocam todos os problemas e que novos tipos de análise são apresentados pelos neoliberais" (FOUCAULT, 2008b, p. 315). Ora, trata-se, nesse caso, de uma política de formação de "bons equipamentos" (FOUCAULT, 2008b, p. 213). Essa formação, no entanto, ultrapassa o simples aprendizado escolar ou profissional e envolve também os investimentos que os pais fazem na formação de seus filhos, incluindo o tempo que lhes consagram fora das atividades escolares, como os destinados ao afeto, aos estímulos culturais, físicos, à dieta alimentar e ao acompanhamento da saúde. Esses cuidados educacionais, de acordo com os neoliberais, constituem investimentos mensuráveis que são capazes de produzir renda. Mas que renda seria essa? De acordo com Foucault (2008b), a renda da criança é o salário que ela receberá quando se tornar adulta, e quanto aos pais será 
uma renda psíquica, que é o resultado da satisfação provocada pelo sucesso dos filhos. Desse modo, a busca pela formação de um capital humano e, na mesma medida, a sua permanente atualização tornarão o indivíduo sujeitado pelos interesses econômicos. A lógica parece simples: o sucesso do trabalhador-empresa depende dos investimentos que ele faz em seu próprio capital, e, ao investir em si mesmo, obedece às demandas de um mercado concorrencial. Além disso, a potência informadora que constitui o capital humano (adquirido) é gerada pela própria forma-empresa.

\begin{abstract}
Não por acaso, aquilo que Foucault denomina de forma-empresa ou a empresa como potência informante ou informacional - aqui poderíamos também acrescentar: a informação como potencial empresarial - constitui o denominador comum em vista do qual proliferam no mundo de hoje manuais de autoajuda cifrados em linguagem empresarial; escolas e universidades começam a se tornar idênticas a shopping centers, e programas televisivos no formato reality show tornaram-se sensação global: prevalece aí a exigência de se autoconstituir de maneira a satisfazer as demandas reais e simbólicas da sociedade empresarial de concorrência. (DUARTE, 2010, p. 264).
\end{abstract}

Vemos, dessa maneira, que até mesmo a estrutura informacional da educação adquire contornos empresariais. E com esses novos contornos os saberes que importam só importam se forem produzidos e filtrados por um cálculo de utilidade. Nesse contexto, o grande pesadelo parece ser o fracasso. Fracassar significa não produzir suficientemente uma renda ou não conseguir submeter-se ao mercado. Significa também, do ponto de vista econômico, que o indivíduo não fez as melhores escolhas de investimento em si mesmo, é uma empresa falida ou em vias de falência. De certo modo, o fracassado é tido como aquele que deixou de observar a potência informadora da forma-empresa e não obedeceu corretamente às "receitas" de sucesso ou, simplesmente, não é possuidor de um bom capital genético. Assim, a responsabilidade pelo fracasso recai exclusivamente sobre o indivíduo: é ele o culpado por não ter sido um bom empresário de si mesmo.

Considerando então esse indivíduo-empresa, que é informado por uma forma-empresa e pode ser a causa do seu próprio sucesso e/ou fracasso (dependendo do investimento que faz em seu capital), é possível notar que o fenômeno do "melhoramento" da vida, ou as tentativas de "produzir seres humanos superiores e 'alterar [lhes] o tamanho, a forma e a função"” (ARENDT, 2010, p. 3), como já anteriormente citado, pode ser lido no registro da produção de "bons equipamentos" humanos, ou no que diz respeito a investimentos em recursos raros (FOUCAULT, 2008b, p. 306). Assim, em meio à racionalidade neoliberal, surge um governo 
empresarial que transforma o fenômeno da vida em um campo privilegiado do saber e em uma instância de intervenção do poder, cumprindo igualmente um projeto de maximização de forças.

A questão agora é que com o aparecimento da "biopolítica neoliberal", associada ao desenvolvimento de tecnologias de otimização da vida ${ }^{19}$, além de uma espécie de transformação no modo de pensar o que é o pensar, o sentir e o decidir humano ${ }^{20}$, essa maximização do fenômeno da vida deixa de ser simplesmente um ideal, ou quase uma ficção, para tornar-se um empreendimento, um incentivo à coletividade e também uma obrigação individual. Talvez a faísca de Zeus nunca tenha reluzido com tanta intensidade: surgem novas promessas, novas possibilidades de reconfiguração do corpo, memória, atenção, volição, emoções, mas também outras formas de aprisionamento, condenação e governo, associados, é claro, à esperança prometeica e ao desejo de novas fugas. As tecnologias de poder ou os biopoderes, nessa direção, passam a atuar nos detalhes biológicos da vida, até mesmo adentrando no mundo do muito pequeno, chegando aos genes e também aos neurônios: "O olhar clínico demorado tem sido provido, se não suplantado, por esse olhar molecular, que está, ele mesmo, enredado em um estilo molecular de pensamento acerca da vida" (ROSE, 2013, p. 26). Da mesma forma que o dispositivo da sexualidade ${ }^{21}$ foi interpretado por Foucault (2014) como a principal chave para a análise da produção disciplinar do corpo e da vida da espécie, encontramos no cenário dos séculos XX e XXI:

[...] uma série de outros valores sobre os quais se pode agir para promover uma capitalização da vida, tais como o DNA, os órgãos e tecidos humanos, as células-tronco, os óvulos [...]. O que se pode testemunhar é o aumento de vitalidade produzida pela reformulação biológica. (ORTEGA; ZORZANELLI, 2010, p. 74).

Cabe notar, ainda, que nesse contexto de reformulação do homem, de sua vitalidade, o cérebro, como veremos, vem ganhando contornos definidores da identidade humana, por meio dele novos processos de subjetivação vêm sendo cultivados. Modelá-lo, remodelá-lo e treinálo corresponde a algumas variáveis a mais no cálculo contemporâneo da vida, cálculo este que parece requerer como resultado final, associado ao governo dos corpos, uma espécie de

\footnotetext{
${ }^{19}$ Esse tema será tratado quando discutirmos sobre a biopolítica contemporânea (ROSE, 2013).

${ }^{20} \mathrm{O}$ assunto será mais detidamente discutido no próximo capítulo, principalmente quando abordarmos o fenômeno da emergência do sujeito cerebral.

${ }^{21}$ Para Foucault (2014), o sexo encontra-se na articulação entre dois eixos. De um lado faz parte das disciplinas do corpo (adestramento, intensificação e distribuição de forças, ajustamento e economia das energias). De outro, pertence à regulação das populações, por todos os efeitos globais que induz.
} 
capitalização e manipulação da alma ${ }^{22}$, isto é, da nossa psique, de nosso noûs, mas agora sendo compreendida como epifenômeno cerebral. Com isso, e apesar disso, é importante pensar também se a vida está ou estará totalmente capturada por esses poderes, ou em que medida ou direção poderia insinuar uma reviravolta.

\footnotetext{
${ }^{22}$ Apesar de várias vezes fazermos referências ao dualismo mente e corpo, não pretendemos aqui alimentar em demasia esse debate. Não gostaríamos de passar a ideia de que somos cartesianos ou filiados a alguma interpretação etérea do ser humano - o usaremos apenas enquanto referência e demarcação histórica filosófica. Pelos termos alma, espírito e noûs, pretendemos apenas afirmar uma espécie de "corpo sútil", ou seguindo Spinoza (2009), um corpo que existe em ato. Sabemos que, para Foucault (2013a), corpo e alma não são simplesmente estruturas naturalizadas do sujeito, mas elementos que fazem parte de uma construção histórica, perpassados por tensões envolvendo poderes e saberes. De certo modo, trabalharemos com a hipótese de que a alma, ou esse "corpo sutil" (uma espécie de software), tornou-se, contemporaneamente, o grande alvo do poder e da governamentalidade biopolítica. Trata-se, então, de corpo e de governo do corpo, mas de um corpo que é, ao mesmo tempo, carne, matéria, forma, afeto, pensamento, cognição, potencial de produção e potência de liberdade.
} 


\section{CAPÍTULO 2}

\section{DO SELF COGITANTE (RES COGITANS) PARA UMA IDENTIDADE SOMÁTICA/CEREBRAL}

Olhando rapidamente para a história, notamos que o ser humano, durante séculos, acostumou-se a compreender a si mesmo como um ente dividido. Por um lado, dotado de um corpo (soma) - uma substância extensa regida pelas leis físicas -, e, por outro, composto de uma alma (psykhé), com características, em princípio, que contradizem as da extensão e/ou materialidade. A alma, substância cogitante, de uma forma um tanto especial foi concebida como conjugada com o próprio corpo: "Nele se aloja, certamente, mas sabe bem dele escapar: escapa para ver as coisas através das janelas dos meus olhos, escapa para sonhar quando durmo, para sobreviver quando morro" (FOUCAULT, 2013a, p. 9). O interessante é que nessa construção ontológica a identidade, ou aquilo que muitas vezes denominamos de self, apareceu, pelo menos no mundo ocidental, mais fortemente próxima da realidade da psykhé que da realidade do soma: "Minha alma é bela, é pura [...]; e, se meu corpo lamacento - de todo modo não muito limpo -, vier a sujá-la, haverá sempre uma virtude, haverá uma potência, haverá mil gestos sagrados que a restabelecerão na sua pureza primeira" (FOUCAULT, 2013a, p. 9). Em Homero (2004), por exemplo, a palavra psykhé já aparece referindo-se a algo distinto da materialidade do corpo: um sopro que sai gritando depois da morte do indivíduo em direção a um mundo invisível, o Hades. Ainda, entre os escritores da Antiguidade grega, mais propriamente na literatura trágica de Eurípedes (1982), Sófocles (2001) e Ésquilo (1999), vemos a indicação ${ }^{23}$ de que os sentimentos humanos, como amor, temor e terror, e toda a capacidade cognitiva coincidiriam plenamente com a psykhé.

Embora nem sempre com as mesmas vestes ${ }^{24}$, essa compreensão dualista do ser também se fez presente na filosofia, sendo percebida em Platão (1999), Aristóteles (1984), Galeno (1995), em pensadores medievais e mesmo modernos. Entre os últimos destaca-se em especial René Descartes (1973), para quem a alma/mente corresponde a uma faculdade intelectiva, constituindo substância de caráter eminentemente racional, inextensa e com o acesso exclusivamente introspectivo: "nada sou, senão uma coisa que pensa, isto é, um espírito, um entendimento ou uma razão, que são termos cuja significação me era

\footnotetext{
${ }^{23}$ Em Édipo rei, de Sófocles: "Ó alma, como me cala". Em Orestes, de Eurípedes: "pois eu sei que a inteligência habita a tua alma".

${ }^{24}$ Há diferentes modos de conceber o dualismo na filosofia, como o de realidade, forma e matéria, substância, propriedade etc.
} 
anteriormente desconhecida" (DESCARTES, 1973 p. 102, grifo nosso). Esse filósofo sugere que pensar e ter a consciência de pensar define o verdadeiro substrato da existência. Em outros termos, para Descartes (1973) somos o que somos porque pensamos como pensamos. O corpo, por sua vez, é interpretado como um mecanismo biológico semelhante a qualquer artifício mecânico: ao sofrer a ação de uma força externa, movimenta-se, e, ao encontrar um obstáculo, choca-se e tende a diminuir até ficar parado. Ao conhecer as leis físicas responsáveis pelo movimento, todo ser munido de razão poderia esquadrinhá-lo e desenvolver uma ciência exata para executá-lo. Assim, se por um lado somos dotados de uma substância mental inextensa e inacessível por métodos não introspectivos (como os científicos), por outro temos também uma substância corpórea que pode ser subjugada e compreendida objetivamente.

[...] há grande diferença entre espírito e corpo, pelo fato de ser o corpo, por sua própria natureza, sempre divisível e o espírito inteiramente indivisível. Pois, com efeito, quando considero meu espírito, isto é, eu mesmo, na medida em que sou apenas uma coisa que pensa, não posso aí distinguir partes algumas, mas me concebo como uma coisa única e inteira. (DESCARTES, 1973, p. 139).

Apesar dessa distinção, o escritor das "Meditações" entreviu que a alma (mente) estava intimamente ligada ao corpo humano por meio de uma glândula, a pineal, localizada no cérebro $^{25}$. A pineal daria origem aos espíritos animados ou a uma espécie de "vento sutil" que circularia no sangue e se espalharia por todo o corpo. Seguindo o raciocínio de Descartes (1973), o ponto de partida de todas as impressões sensoriais e o comando dos movimentos corpóreos se localizariam no cérebro. Os espíritos animais seriam, então, os responsáveis pela transmissão dos estímulos da alma, que, saindo do cérebro, iriam para toda a substância corpórea. Dessa forma, o corpo humano, apesar de estar sujeito a forças que lhe seriam externas, também possuiria um princípio interno e autônomo de movimentação: "posso não apenas mover-me e remover-me, como posso também 'movê-lo', removê-lo, mudá-lo de localização" (FOUCAULT, 2013a, p. 7).

Nesse cenário dualista, a mente é concebida como uma substância que se relaciona com o corpo do mesmo modo que um cavaleiro se relaciona com seu cavalo ${ }^{26}$ : ele monta,

\footnotetext{
${ }^{25}$ Entretanto, o cérebro não foi um objeto filosófico para Descartes (1973). Mesmo desempenhando um papel importante, o cérebro é considerado por esse pensador um órgão secundário que recebe e transmite informação sem gozar da mínima autonomia simbólica. Segundo Malabou (2014, p. 27), por exemplo, até o fim do século XIX "Jamais um filósofo se perguntou se o cérebro podia, enquanto tal, sofrer, ter representações, ser o centro de uma economia significante".
} 
domina e conduz o animal, fazendo prevalecer a sua vontade. O corpo é tido como o próprio animal que deve ser dominado, uma substância extensa dotada de reflexos, mas não de uma vontade consciente e/ou autônoma. De outro lado, a mente é o cavaleiro que domina a animalidade do corpo. Nessa direção, temos uma rápida indicação do que seria o sujeito para os pensadores modernos, principalmente para Descartes (1973): um ente autônomo que se localiza em um corpo, mas que não é reduzível a ele.

Ao identificar o homem como sujeito, Descartes (1973) o coloca na categoria de senhor da substância mental e o contrapõe ao mundo como objeto corpóreo a ser dominado. Resumindo, para esse filósofo, somos uma coisa pensante dentro de um corpo ou, usando de uma linguagem atual, "um fantasma na máquina" (RYLE, 2000), e o conhecimento dessa coisa pensante, o “eu”, precede o conhecimento e o domínio do corpo.

Esse modo dualista de nos compreendermos, acrescido de uma forte influência judaico-cristã, repercutiu, como é sabido, nos empreendimentos científicos do mundo ocidental, principalmente por meio da noção de uma "razão desprendida" e de um sujeito desencarnado que se debruça sobre um mundo natural objetificado. Também ocasionou reflexos na organização e condução da vida, alcançando questões de política, moral, saúde, sexualidade e educação. De maneira geral, a separação entre mente e corpo foi uma ferramenta heurística útil nos períodos que antecederam os séculos XX e XXI.

Ao interrogar as bases da psicologia e da psiquiatria do século XVIII e assinalar as práticas discursivas da loucura, Foucault (2013c), por exemplo, afirma que a separação entre mente e corpo, de certo modo, persistiu - então associada à classificação e ao tratamento do "lunático" -, privilegiando em alguns momentos o que aparentava ser uma espécie de fraqueza da alma e/ou falta moral. Segundo o autor, para os "alienistas" desse período, todos os "eventos da alma" que fossem um pouco violentos, ou exageradamente intensos, poderiam desencadear a loucura, como "as paixões da alma, as contenções do espírito, os estudos forçados, as meditações profundas, a cólera, a tristeza, o temor, os pesares longos e pungentes, o amor desprezado [...]” (FOUCAULT, 2013c, p. 245).

Ora, o problema é que, atualmente, tal imagem dualista que fizemos de nós mesmos e todas as práticas sociais a ela veiculadas mostram-se confusas ${ }^{27}$ e esgotadas (SEARLE, 1997).

\footnotetext{
${ }^{26}$ Nessa relação entre o corpo e a alma, o que está em jogo é “[...] o problema da liberdade: o excesso da alma em relação ao corpo" (BARBARAS, 2003, p. 66). De certa forma, a intuição que temos é de que, por si só, a experiência da liberdade já seria o suficiente para corroborar a existência da alma. Apesar da divisão do corpo ser concebida como uma tarefa exclusivamente mecânica, a alma, dada a sua natureza, não se submeteria aos mesmos processos.
} 
Essa imagem constituiu, principalmente a partir do século XX, um poderoso obstáculo para uma compreensão científica do lugar dos fenômenos mentais dentro do mundo físico e, ao mesmo tempo, dificultou também um "governo externo" desses fenômenos, além de uma incursão biopolítica sobre o menta ${ }^{28}$. Superando esse obstáculo, um novo regime de verdade sobre a nossa própria identidade começou a ser construído. Nele, o corpo ganhou notoriedade, a alma incorpórea passou a ser exorcizada e a velha máxima cartesiana de que "penso, portanto sou", pouco a pouco, começou a ser substituída por outra que diz que o corpo pensa e o sujeito desse pensamento, antes incorpóreo, está encarnado em sua própria estrutura e história cerebral.

Cabe notar, em paralelo ao processo de reestruturação ontológica e epistemológica de nossa identidade - cujos detalhes apenas nos interessará os da "cerebralização" -, que alguns pensadores passaram igualmente a problematizar a materialidade do corpo. Foucault (2013a, p. 7-8), por exemplo, afirma que o corpo é um lugar, "topia implacável”, ou ainda, "lugar sem recurso ao qual estou condenado". Em vez de simplesmente fitá-lo por uma perspectiva mecânica, ou cartesiana, o autor prefere tomá-lo como um vértice que se abre às possibilidades de fuga, um ponto de tensão ${ }^{29}$. Diz que é contra o corpo, e como para apagá-lo, que fazemos nascer todas as utopias, os lugares fora de todos os lugares, "o país das fadas, o país dos duendes, [...] o país dos mortos, [...] o mito da alma” (FOUCAULT, 2013a, p. 8-9). Afirma - a despeito de uma aparente anulação do corpo por essas utopias -, que o corpo, contra o qual se produz as utopias ou lugares nenhuns, é ele mesmo um lugar nenhum, possui também lugares sem lugar, tão profundos quanto a própria "alma" ${ }^{30}$. O filósofo dá a entender que a utopia que emerge do corpo - como a alma enquanto um não lugar -, para ele, ou contra ele, também se volta: “O corpo é o ponto zero do mundo, lá onde os caminhos e os espaços se cruzam" (FOUCAULT, 2013a, p. 14). O pensador francês diz ainda que:

[...] o corpo na sua materialidade, na sua carne, seria o produto dos seus próprios fantasmas. Afinal, o corpo do dançarino não é justamente um corpo dilatado segundo um espaço que lhe é ao mesmo tempo interior e exterior? E os drogados também, e os possuídos; os possuídos cujo corpo se torna

\footnotetext{
${ }^{27} \mathrm{O}$ esgotamento do dualismo não significa o seu fim. Muitos debates atuais em filosofia da mente, ciência cognitiva e psicologia ainda giram em seu entorno. No entanto, devemos notar que, ao longo do século XX, muitas tentativas de superá-lo foram feitas, como o behaviorismo, as teorias de identidade tipo e ocorrênciaocorrência (o estado mental $X$ é idêntico ao evento neurofisiológico $Y$ ), funcionalismo, materialismo eliminativista, teorias neurológicas reducionistas, entre outras.

${ }^{28}$ No caso da loucura, antes do século XX, como apontado por Foucault (2013c), embora falassem sobre controle mental, doença mental, o corpo é que era isolado: a nau dos loucos e, posteriormente, a "grande internação".

${ }^{29}$ Nesse sentindo, curiosamente, parece que o próprio corpo, e não a alma, poderia ser exorcizado.

${ }^{30}$ Aqui, a alma pode ser interpretada como um não lugar, uma utopia que emerge do próprio corpo.
} 
inferno; os estigmatizados, cujo corpo se torna sofrimento, resgate e salvação, ensanguentado paraíso [...]. As crianças, afinal, levam muito tempo para saber que têm um corpo. Durante meses, durante mais de um ano, elas têm apenas um corpo disperso, membros, cavidades, orifícios, e tudo isso se organiza, tudo isso literalmente toma corpo somente na imagem do espelho. De modo mais estranho ainda, os gregos de Homero não tinham uma palavra para designar a unidade do corpo. Por paradoxal que seja, diante de Tróia, abaixo dos muros defendidos por Heitor e seus companheiros, não havia corpos, mas braços erguidos, peitos intrépidos, pernas ágeis, capacetes cintilantes em cima de cabeças: não havia corpo. (FOUCAULT, 2013a, p. 14-15).

Desse modo, o autor conjectura que corpo e alma não são apenas estruturas naturalizadas do sujeito, mas elementos que fazem parte de uma construção cultural, simbólica e histórica. Com isso, o que Foucault (2013a) parece estar sugerindo, e é o que nos interessa, é a possibilidade de questionar certa "dureza" fria e contínua da própria materialidade do corpo, sinaliza uma espécie de corpo sutil, passível a tensões e atravessamentos, um ator utópico que pode ser arrancado de seu espaço próprio e lançado em outros lugares $^{31}$. As máscaras, maquiagens, tatuagens, segundo ele, auxiliariam nessa tarefa de criar outros signos e outros lugares para o corpo, mas a prótese, o prolongamento de membros, a redesignação sexual, a modelagem e remodelagem do corpo, a fitness, o controle dos humores, a potencialização da memória e atenção etc. - associados aos novos saberes talvez cumpram esse mesmo papel nos dias de hoje, constituindo práticas de poder e saber sobre o corpo e suas sutilezas.

\subsection{DO DUALISMO MENTE E CORPO PARA O MONISMO CEREBRAL E A CONDUÇÃO DA VIDA}

Considerando as transformações envolvendo a noção de identidade, algo que nos chama atenção e que será aqui motivo de reflexão, é a ênfase oferecida ao domínio racional dos fenômenos mentais (pyskhé). De outro modo, há certo investimento político, científico e econômico direcionado a manipulação do "eu", o qual, graças ao desenvolvimento científico e tecnológico, passou a ser lido nas miríades celulares de nossa estrutura encefálica. Atualmente, o domínio e o investimento nesses fenômenos parecem contar, pragmaticamente, muito mais para um cálculo político da vitalidade do que para a resolução de problemas

\footnotetext{
${ }^{31}$ Como veremos, o cérebro/corpo foi arrancado de dentro da cabeça, levado ao laboratório, do laboratório para a sociedade - por meio da mídia - e da sociedade para o coração da economia e da empresa.
} 
tradicionais da filosofia, como o da relação entre mente e corpo (embora este permaneça ainda bastante vivo no debate contemporâneo, principalmente na filosofia da mente e na ciência cognitiva, e claro, na religião). Em outros termos, o que parece interessar na contemporaneidade principalmente para uma política da vida que funcione como guia para a condução de nossas práticas sociais, é a inserção de um projeto de governamentalidade da vida por meio da gestão dos fenômenos mentais ou, ainda, um enquadramento e governo daquilo que existe de mais sutil na materialidade do corpo. Assim, já não basta disciplinar os corpos dos indivíduos e nem normalizar o corpo social, tal como assinalado por Foucault (2014), faz-se necessário, para a consolidação de uma biopolítica atual, governar também certo potencial cognitivo e afetivo - entendidos agora como sutilizas neuroquímicas, hormonais e informacionais tecnicamente decodificáveis e modeláveis, ou ainda, encontros e desencontros ocorridos na (micro)estrutura do corpo.

Com isso, as características "mentais" dos indivíduos - agora reduzíveis ao corpo/cérebro -, como memória, atenção, emoções, senso moral, intencionalidade, aprendizagem, volição, gosto refinado, cognição, entre outras, que, em linhas gerais, ficaram excluídas do saber e do cálculo científico, passaram a ser, da mesma forma que o corpo, e mais ainda, enquanto corpo - sutil ${ }^{32}$ e molecular ${ }^{33}-$, alvos dos saberes científicos e das novas formas de exercício do poder: tornaram-se problema de Estado, matéria de governo, assunto de saúde pública, preocupação empresarial, chave para a interpretação das questões de gênero, assunto de autoperformance e também questão educacional. De outro modo, podemos dizer, de acordo com o pensamento de Foucault (2014), que os estados mentais passaram a fazer parte da lista dos interesses de um poder que atua diretamente sobre a vida.

Em grande medida, o que pensamos ser um projeto de governamentalização da vida por meio de um enquadramento dos fenômenos mentais, daquilo que existe de mais sutil em nossa materialidade - constituindo também uma modalidade de gerência da conduta dos indivíduos e da população -, está sendo alavancado, como veremos mais adiante, pelo aparecimento de uma cultura somática e por pesquisas que buscam desvendar, desde meados do século XX, e mesmo antes disso ${ }^{34}$, os correlatos biológicos (cerebrais) da experiência

\footnotetext{
${ }^{32}$ Segundo Foucault (2013b), o próprio Georges Canguilhem, respeitável médico e filósofo francês, deu importância ao encontro nas ciências da vida entre a velha questão do normal e patológico e o conjunto das noções que a biologia, durante a segunda metade do século XX, tomou emprestado da teoria da informação: códigos, mensagens, mensageiros, transmissores, receptores etc. E, mediante os jogos dos códigos e das decodificações, abriu-se, por exemplo, lugar para o acaso, que, antes de ser doença, déficit ou monstruosidade, passou a ser admitido como uma perturbação no sistema informativo, algo como um "equívoco".

${ }_{33}$ Comentaremos sobre o processo de molecularização da vida quando discutirmos sobre a biopolítica contemporânea, amparados em Rose (2013).
} 
subjetiva. Essas pesquisas, de modo geral, alimentam uma crença bastante forte, popularizada até mesmo entre o público leigo, de que ao desvendar esses correlatos é possível interferir na própria identidade do sujeito, corrigindo-o e, ao mesmo tempo, melhorando-o.

“CÉREBROS MELHORES", proclamava a capa de uma edição especial da Scientific American em 2003, e os títulos dos artigos da revista formavam o prospecto de um sonho para o futuro: "A busca de uma pílula da inteligência"; "Máquinas que leem o cérebro"; "Estimuladores do cérebro", "Genes da psique"; "Controle do estresse". Esses, parece, eram os compromissos oferecidos pelas novas ciências do cérebro, prometendo ultrapassar em muito a genética como "o próximo grande feito científico". As expressões tropeçam ligeiramente na língua, ou gritam para nós das capas sensacionalistas dos livros. Há de existir um "futuro pós-humano" no qual "as pessoas de amanhã" serão o que outros autores descrevem como "entes neuroquímicos". (ROSE, 2006, p. 9).

Vemos, então, que, contrariando a visão dualista de mundo, na qual apenas o corpo poderia ser objetivamente compreendido e esquadrinhado, eis que surgem na atualidade formas de saber e práticas que tendem a submeter, esquadrinhar e governar a própria alma dos indivíduos. É dentro desse cenário que emerge, como já indicado, e se consolida uma espécie de projeto de naturalização da mente ou de condensação do sujeito no cérebro. No lugar de um sujeito autônomo, localizado em um corpo, mas não reduzível a ele, surge outro, que é todo corpo: somático, transparente, neuroquímico, cerebral e governável (COSTA, 2004; ORTEGA; VIDAL, 2007; ROSE, 2013).

Os vestígios da emergência desse novo sujeito podem ser percebidos em uma ampla gama de manifestações socioculturais, uma vez que estão presentes no marketing de laboratórios farmacêuticos que produzem (psico)fármacos, em programas apresentados por veículos de comunicação de massa, em títulos que aparecem cotidianamente nas prateleiras das livrarias e bibliotecas, tais como: $A$ árvore do conhecimento (Humberto Maturana $\mathrm{e}$ Francisco Varela, 2004); A mente corpórea (Francisco Varela, Evan Thompson e Eleanor Rosch, 2001); O erro de Descartes (António R. Damásio, 1996); Biologia da consciência (Gerald Edelman, 1995); O homem neuronal (Jean-Pierre Changeux, 1985), entre outros. Visualizamos essa circunstância também em capa de revistas, como a Mente \& Cérebro, na

\footnotetext{
${ }^{34}$ Lembremos os trabalhos sobre frenologia, desenvolvidos por Franz Joseph Gall e popularizados por Johann Spurzheim, no século XIX, que se fundamentavam no princípio de que o cérebro, que devia ser o órgão da mente, era composto de diferentes partes, sendo que cada uma representava uma faculdade específica, e o tamanho dessas diferentes regiões, avaliado pelo crânio, refletia a potência da faculdade que elas continham. Lembremos também os trabalhos dos pesquisadores localizacionistas, como Pierre Paul Broca e Carl Wernicke, no fim do século XIX, que relacionaram, localmente, a capacidade humana de falar com o hemisfério esquerdo do cérebro. Além dos antilocalizacionistas, John Hughlings Jackson, Pierre Marie e até mesmo Sigmund Freud, que entre outras coisas intuíram o princípio da plasticidade do sistema nervoso.
} 
qual aparecem títulos curiosos, a saber: "Como o cérebro aprende"; "Doenças do cérebro"; "Mente, cérebro e arte"; "Como melhorar o desempenho do seu cérebro"; "Os superpoderes do cérebro"; "7 segredos do cérebro saudável”; entre outros. No debate educacional, aparecem: Neurociência e educação (Marta Relvas, 2010); Neurociência e aprendizagem (Elvira Souza Lima, 2010); O cérebro vai à escola (Felipe Stephan Lisboa, 2016); Que cérebro é esse que chegou à escola? (Marta Relvas, 2012). Além, é claro, de assistirmos à consagração dos anos de 1990, pelos Estados Unidos, como "a década do cérebro", com o presidente americano George Bush afirmando que a população deveria aumentar a consciência pública dos benefícios a serem alcançados pelas pesquisas sobre o cérebro ${ }^{35}$.

Pensamos que esses vestígios, e muito outros, indicam que as formas contemporâneas de subjetivação estão passando por um processo de modificação, além de estarmos vivendo um momento de tensão entre uma visão de mundo solipsista que se apresenta decadente e uma nova concepção de nós mesmos que se consolida por meio de um processo de somatização e externalização de nossa experiência subjetiva, na qual é possível perceber certa centralidade em um discurso progressista e uma ciência do cérebro.

Para Francisco Ortega e Rafaela Zorzanelli (2010), esses vestígios mostram que o sentido de nós mesmos como indivíduos habitados por um espaço interno, de alegrias, sofrimentos, esperanças e escolhas, está sofrendo um processo de modificação "no qual passamos a definir aspectos-chave da subjetividade em termos corporais e biomédicos" (ORTEGA; ZORZANELLI, 2010, p. 63). Segundo esses autores, as emoções comuns, como medos e aspirações, estariam sendo decodificadas em um vocabulário médico e estaríamos estabelecendo uma nova grade de relações com o nosso corpo que incluiria desde práticas comuns de correção até processos de melhoramento e/ou potencialização por meio de manancial (psico)farmacológico e mecânico: "Esses processos dizem respeito, sobretudo, a práticas socioculturais em que se privilegia a exposição do corpo e a da vida privada" (ORTEGA; ZORZANELLI, 2010, p. 64). Nessa direção, vemos que o corpo é quem passa a identificar o sujeito, e o cérebro assume uma posição-chave que outrora pertenceu à interioridade da psykhé.

O cérebro constitui a essência daquilo que nos define como seres humanos. Compreender a sua estrutura e funcionamento é compreendermo-nos a nós próprios. O cérebro saudável normal é um órgão complexo, miraculoso e

\footnotetext{
${ }^{35}$ De acordo com Zorzanelli e Ortega (2011), deriva daí uma ascensão do campo das neurociências, um campo que reúne muitas subáreas diferentes, como a neurociência molecular, a genética psiquiátrica, a neurogênese, o imageamento cerebral, o desenvolvimento de medicamentos psicofarmacológicos, entre outras.
} 
engenhosamente criado. Permite-nos alcançar as maravilhas da música, da arte, da ciência, da arquitetura, da engenharia, da organização política e da estrutura econômica. Cada um de nós foi dotado de um cérebro único com capacidades particulares, as quais tanto podemos aumentar através da aprendizagem e do trabalho produtivo como desperdiçar através da inactividade intelectual e de hábitos de vida insalubres. (ANDREASEN, 2003, p. 55).

Assim, todos aqueles atributos que antes eram associados à interioridade da alma e caracterizavam a personalidade passam agora a ser compreendidos em questões biológicas, por exemplo, pela configuração neuroquímica. Com isso, vários espaços para intervenções na identidade - bioidentidades/neuroidentidades - são abertos, principalmente por meio de ações sobre a estrutura cerebral: para a tristeza, recomendam-se antidepressivos; para a ansiedade, os tranquilizantes; para a desatenção e o mau comportamento das crianças e adolescentes, ou Transtorno do Déficit de Atenção com Hiperatividade (TDAH), são indicados o metilfenidato (Ritalina) e dextroanfetamina (Adderall) (ROSE, 2013). Nesse cenário de biologização do self $f^{36}$, a neurocientista Andreasen (2003, p. 13), por exemplo, diz que o objetivo do século XXI é descobrir uma penicilina para a doença mental: "Gostaríamos de combater a esquizofrenia ou a demência tão eficazmente como atualmente combatemos doenças infecciosas [...]. Esperamos descobrir um admirável mundo novo em que as doenças mentais, hoje aflitivamente comuns, se tornem raras e facilmente tratáveis".

Se os aspectos biológicos do ser humano, tal como nos aponta Foucault (2014), desde o século XVII já haviam se tornado objetos de investimento político e alvos dos mecanismos de exercício do poder, seja por uma configuração anátomo-política ou biopolítica - cuja operação principal seria a incitação à produção de formas de relação consigo por meio de um controle minucioso dos gestos, do corpo, do espaço, do tempo, do nível de saúde, da duração da vida, dos índices de nascimento, mortalidade, longevidade etc. -, parece que agora a própria identidade é que passou a ser motivo de investimentos, o self biológico é que se tornou o principal alvo do poder ou de uma governamentalidade biopolítica que o incita de acordo com interesses específicos, como o do ideal de melhoramento da performance.

Em outros termos, admite-se que o indivíduo pode fazer progressos contínuos, pode ser melhorado e/ou melhorar a si mesmo ${ }^{37}$ por meio de estímulos cerebrais, "bons hábitos", da "aprendizagem e do trabalho produtivo" e também por vias medicamentosas, naquilo que

\footnotetext{
${ }^{36}$ Essa biologização do self é algo que acontece no "universo do muito pequeno" (neurônios, sinapses, neurotransmissores etc.), talvez possamos falar em uma "neuroquimização" do self.

${ }_{37}$ Pensamos que esse indivíduo está em conformidade com a ideia do homo economicus apresentada por Foucault (2008) na medida em que ele se torna um "empresário de si mesmo".
} 
Rogério Azize (2010) denomina de uma peculiar Bildung neurológica e Ortega (2009b) chama de técnicas cerebrais de construção de si.

Nessa direção, temos, por exemplo, o desenvolvimento de pesquisas utilizando neuroimagens para decifrar "[...] não somente doenças como Alzheimer e Parkinson, mas também a natureza das nossas escolhas sexuais, nossos gostos e nossas características pessoais" (ORTEGA; ZORZANELLI, 2010, p. 77). Aparecem, nesse mesmo contexto, entre o fim do século XX e início do século XXI, disciplinas como a "ciência do aprendizado ou neuroaprendizagem" e/ou, ainda, "neuroeducação", que se propõem a construir um conhecimento sobre o aprendizado e desenvolver práticas pedagógicas concretas ou simplesmente formas de gerência da conduta dos indivíduos, processo agora fundamentado em um pretenso conhecimento sobre o cérebro ${ }^{38}$. Ademais, surge também um debate sobre métodos e práticas de potencialização da subjetividade: ginástica cerebral (brain fitnes), softwares computacionais, jogos para estimulação cerebral. No Brasil, torna-se bastante popular o modelo Supera ${ }^{39}$ de ensino, que se propõe a melhorar o desempenho cognitivo de seus "clientes" ${ }^{40}$ por meio de exercícios cerebrais, ou neuróbica ${ }^{41}$.

Abre-se, desse modo, a despeito da seriedade e dos benefícios de muitas pesquisas sobre o cérebro, um grande mercado de manipulação, construção e condução da subjetividade que usufrui dos ares de um discurso cientificista: “[...] por um lado, as práticas da ciência da medicina e tecnologia formam selves mediante a experimentação científica, [...] por outro, os indivíduos formam seus próprios modelos de self a partir dos fatos científicos" (ORTEGA, 2009b, p. 249). Nesses investimentos, de modo geral, é possível perceber algo bastante comum: há certa convicção e também uma promessa, confirmada por pesquisas atuais em neurologia, de que o cérebro, órgão que anima a mente, é um sistema aberto ${ }^{42}$, "sumamente

\footnotetext{
${ }^{38} \mathrm{O}$ discurso é de que esse tipo de educação pode tornar os sujeitos mais competitivos, empreendedores e produtivos.

39 “O SUPERA é um sistema de ensino e treinamento individualizado que visa ao desenvolvimento pessoal e profissional, potencializando a criatividade, a concentração, o raciocínio lógico, a autoconfiança, a autoestima, a disciplina e a perseverança. Desenvolve, também, conceitos como planejamento pessoal, relacionamento interpessoal, inteligência financeira, atitudes construtivas e muitos outros. As habilidades e conceitos desenvolvidos pelo SUPERA são fundamentais para o sucesso na vida acadêmica, pessoal e profissional, proporcionando grande desenvolvimento aos alunos de todas as faixas etárias. Em apenas seis anos o SUPERA se tornou uma rede de franquias com 200 unidades, presentes em todas as regiões do Brasil, atendendo milhares de pessoas e sendo reconhecido por educadores e alunos como centro de excelência para o desenvolvimento pessoal" (Home, Supera, Instituto de Educação). Disponível em: http://www.franquiaeducacional.com/quemsomos/._Acesso em: 12 jan. 2018.

${ }^{40}$ No início, o método Supera foi direcionado às crianças, no entanto, atualmente, é procurado por idosos que desejam um rejuvenescimento cerebral e também por empresas que objetivam potencializar a capacidade de produção de seus "colaboradores", maximizando suas capacidades cognitivas.

${ }^{41}$ A ideia principal é simples: o cérebro funciona como um músculo, quanto mais usá-lo, mais forte ele ficará.
} 
maleável, sumamente plástico, passível de ser transformado e de transformar interações sociais de todos os tipos" (ROSE, 2010, p. 311). Com isso, ele se torna alvo de interesse político, educacional, científico, empresarial, econômico, religioso e de outros mais. Busca-se, enfim, a produção de "cérebros melhores", “bons equipamentos” (FOUCAULT, 2008b), ou o que podemos chamar de capital mental. E é especificamente nesse ponto - melhoramento da performance e produção de capital mental - que percebemos, contemporaneamente, aquilo que Foucault (2014, p. 146) também denomina de dimensão positiva e produtiva do poder: "um poder destinado a produzir forças, a fazê-las crescer e a ordená-las mais do que barrá-las, dobrá-las ou destruí-las".

Corrigir, e principalmente otimizar a performance humana por meio de interferências cerebrais, parece coincidir, como veremos, com o discurso da biopolítica contemporânea. De certa forma, a "mente", entendida atualmente como um fenômeno, ou um epifenômeno biológico, começa a fazer parte, talvez como o principal elemento da vida humana, de uma política da própria vida (ROSE, 2013). A questão de saber como pensamos e sentimos deixa de ser assunto exclusivamente teórico para entrar nas estratégias e práticas atuais do poder ${ }^{43}$. O cérebro torna-se, então, uma peça central para a realização desse objetivo, pois, por meio dele os indivíduos podem ser remodelados, potencializados, governados, mas também situados em um modo de resistência ao biopoder ${ }^{44}$. De outra forma, emerge no contexto da biopolítica contemporânea, ou talvez por causa dela, a figura antropológica (e especialmente ontológica) do sujeito cerebral (ORTEGA; VIDAL, 2007), um sujeito aberto ao cálculo e à manipulação racional.

\subsection{O SUJEITO CEREBRAL}

A ideia de um sujeito cerebral representa, logo de início, uma antítese à concepção moderna de subjetividade, em vez de penso, portanto sou, agora sou, se e somente se tenho um cérebro que pensa: "Se penso como penso, se sinto o que sinto, se faço o que faço, enfim, se sou como sou, é porque meu cérebro é como é" (WINOGRAD, 2010, p. 521). Admite-se que o pensamento e a experiência subjetiva podem ser entendidos e explicados pela atividade de nossa estrutura cerebral, ou ainda que a identidade pessoal está no cérebro, que o cérebro é

\footnotetext{
${ }^{42} \mathrm{O}$ cérebro como um sistema aberto está inserido nos debates atuais, que o tratam como um órgão que possui plasticidade, isto é, como uma estrutura que pode ser modificada até a idade avançada.

${ }^{43}$ Entendendo por poder o que Foucault (2014) aponta como sendo uma espécie de produção em ato, a imanência da produtividade, aquilo que também está em estreita relação com o saber - nesse caso com os neurossaberes.

${ }^{44}$ Abordaremos a temática "resistência" no último capítulo deste trabalho.
} 
necessário e suficiente para definir quem somos.

Os ecos desse discurso cerebrocentrista é evidenciado e cristalizado, cotidianamente, mesmo fora do âmbito clínico e laboratorial, espalhando-se por toda a cultura em um "intenso processo de popularização, pela mídia, de imagens e informações que associam a atividade cerebral a praticamente todos os aspectos da vida" (ORTEGA, 2009b, p. 249). Se quarenta anos atrás, as pessoas causavam sensação “[...] em reuniões mundanas, falando de investimento, de reações contrafóbicas ou de pulsões libidinais. Atualmente, reúnem-se informalmente e bebem a água mineral da moda com uma rodela de limão enquanto falam da amígdala e dos lobos frontais" (ANDREASEN, 2003, p. 67). As relações entre mente-corpocérebro deixaram de ser temas exclusivos das discussões entre especialistas para tornarem-se um assunto de preocupação comum em virtude do sofrimento psíquico e da saúde mental. A popularização desse discurso pode ser percebida até mesmo em representações ${ }^{45}$ teatrais.

(O primeiro bloco de diálogo se passa em um consultório médico; as cenas são projetadas em uma tela atrás dos atores que já estão no palco)

Hernán: - Su hígado ya no funciona. Si lo reemplazamos por otro, usted podrá seguir vivendo. ¿Acepta?

Susana: - Acepto.

Hernán: - Su corazón no está trabajando bien. Si lo reemplazamos por otro, ustede podrá seguir vivendo. ¿Acepta?

Susana:-Acepto.

Hernán: - Su cérebro tiene dificuldades. Si lo reemplazamos por otro, usted podrá seguir vivendo. ¿Acepta?

Susana: - ...

Hernán: - ¿Acepta?

(No palco, comentando a cena que se passou)

Susana: - Qué mal tenía él pelo esse día.

Rosário: — ¿Vos aceptarías?

Susana: - ... hay días que sí.

Rosário: - Yo no, no quiero dejar de ser yo justo ahora que me conosco un poco más. (BLÉFARI; PAMPÍN, 2003 apud AZIZE, 2010, p. 17).

Seja acomodado no assento de um restaurante ou no palco de um teatro, referenciar a identidade, contemporaneamente, é fazer alusão ao cérebro. Exageros à parte, se fôssemos atualizar a velha máxima e o exercício socrático de "conhecete a ti mesmo", talvez o primeiro passo, comum ao século XXI, correspondesse à

\footnotetext{
${ }^{45}$ Segundo Azize (2010), a peça foi encenada na Argentina, baseada em textos do psiquiatra Sergio Strejilevich, cujo título é Nós somos o nosso cérebro.
} 
produção de uma imagem do cérebro. Um relatório da academia de Ciências, por exemplo, "sublinha que apreender o cérebro é indispensável a fim de compreendermos a nós mesmos" (KORN, 2003 apud EHERENBERG, 2009, p. 188). $E$, ainda, se fôssemos reescrever Descartes, parafraseando-o sob uma ótica cerebralista, talvez disséssemos agora que: "Somos, existimos: isto é certo; mas por quanto tempo? A saber, por todo o tempo em que temos um cérebro vivo"46. $\mathrm{O}$ cérebro, esse órgão formado por uma rede complexa de aproximadamente cem bilhões de neurônios, tornou-se o elemento principal para a representação atual de nós mesmos enquanto sujeitos, é ele que se vem oferecendo - ou sendo oferecido como chave interpretativa de nossa identidade. Então "chamamos de 'sujeito cerebral' a figura antropológica que incorpora a ideia de que o ser humano é essencialmente reduzível a seu cérebro" (ORTEGA; VIDAL, 2007, p. 257).

De maneira geral, o cérebro passou a ser compreendido, principalmente a partir da segunda metade do século $X X$, como aquilo que nos delimita como pessoa. Se fizéssemos um transplante de fígado, coração, córneas ou rins, tomando como referência o diálogo da peça teatral, a impressão é de que continuaríamos sendo nós mesmos, mas, se hipoteticamente pudéssemos fazer um transplante de cérebro, a percepção possivelmente poderia ser outra: talvez como se abandonássemos ${ }^{47}$ a nossa própria identidade - "Yo no, no quiero dejar de ser yo"- o que se perderia é a própria pessoa e, consequentemente, "o que se receberia é um outro indivíduo, que passaria a ocupar aquele corpo" (AZIZE, 2010, p. 17-18). Nessa direção, há uma intuição comum, pelo menos aparentemente, que diz que, se $X$ doar o cérebro para $Y$, não é $Y$ quem ganhará um novo cérebro, mas $X$ é quem passará a ter um novo corpo. Daí a fórmula lógica do sujeito cerebral: $A=A^{*}$ se, e somente se, $A$ e $A^{*}$ tiverem o mesmo cérebro. "A 'pessoa' assim definida seria um sujeito cerebral $\mathrm{e}$ seria caracterizada pela propriedade da 'cerebralidade', isto é, a propriedade ou qualidade de ser, ao invés de apenas ter um cérebro" (ORTEGA; VIDAL, 2007, p. 258).

Ora, a partir da constatação dessa que parece ser uma virada ontológica, isto é, da emergência de um sujeito encerrado em sua própria estrutura cerebral - o qual

\footnotetext{
${ }^{46}$ No original: "Eu sou, eu existo: isto é certo; mas por quanto tempo? A saber, por todo o tempo em que eu penso" (DESCARTES, 1973, p. 102). A reescrita dessa frase, tal como sugerido, remete, sobretudo, ao debate sobre morte cerebral - ainda que o sistema circulatório e respiratório de um indivíduo funcione, se o cérebro for considerado morto, o indivíduo será tido como morto.

${ }^{47}$ Essa reflexão, como veremos, é válida principalmente em casos de patologias e/ou acidentes cerebrais.
} 
não está restrito nem ao debate filosófico nem ao científico, encontrando-se presente também nas discussões cotidianas, uma vez que diz respeito ao modo contemporâneo de estar no mundo -, duas questões podem ser levantadas: a primeira diz respeito ao processo, ou pelo menos às pistas, que levaram ao seu aparecimento. Afinal, como chegamos ao ponto em que alguém poder dizer "Você é o seu cérebro"? E a segunda, talvez a mais importante e mais difícil, está relacionada às possíveis consequências epistemológicas, ontológicas, morais, políticas, econômicas e educacionais desse acontecimento.

A resposta à primeira questão, ainda que não seja completa, pode ser oferecida fazendo alguns apontamentos rápidos sobre os efeitos de uma cultura somática nas sociedades atuais, como os apresentados por Zorzanelli e Ortega (2010), bem como algumas observações históricas que remetem a tentativas de associar as faculdades mentais a certas localizações encefálicas, apresentadas, por exemplo, por Andreasen (2003) e Ehrenberg (2009). Já a resposta à segunda questão, mesmo que em caráter de sugestão, talvez possa ser explorada ao associarmos a figura do sujeito cerebral a algumas das características contemporâneas da biopolítica, em especial as que são apresentadas por Nikolas Rose (2013, p. 16) quando o autor refere sobre "uma política da vida em si mesma", além de também observar algumas das práticas sociais relacionadas a esse novo sujeito, como é o caso da política de melhoramento das performances e a inserção de uma dimensão "neuro" na educação.

Antes de adentrarmos nesse debate, no entanto, é importante lembrar que, para Foucault (2008b), na racionalidade neoliberal a lógica do homo oeconomicus e seu potencial sígnico/representacional fez com que o próprio indivíduo, suas habilidades e competências se convertessem em capital. A questão é que na biopolítica contemporânea, como veremos, o investimento na formação de indivíduos produtivos, ou o incentivo ao autodesempenho para que sejam "empresários de si mesmos", parece passar por uma maximização que agora não é mais restrita a um corpo que possui um self, mas a um sujeito que é ele mesmo um cérebro.

Nessa parte do debate, uma das pistas ${ }^{48}$ usadas para esclarecer a primeira questão é a demarcação do surgimento de uma "cultura do corpo" em oposição a

\footnotetext{
${ }^{48}$ Esse pano de fundo é usado, entre outros, por Costa (2004), Zorzanelli e Ortega (2011) e Rose (2013).
} 
uma concepção filosófico-religiosa que influenciou, do século XVIII até a primeira metade do século $X X$, as sociedades burguesas do Ocidente. Trata-se da mudança de uma cultura da intimidade em que a personalidade do sujeito, ou o seu self, era compreendida como uma entidade encerrada em uma interioridade psicológica, mas que se desloca para outra em que o corpo é quem vai assumir os papéis definidores da identidade.

Vale notar que o indivíduo na cultura da intimidade fora educado para acreditar que o que ele próprio era não podia ser corporalmente revelado ou modificado e, assim, tornava-se capaz de fingir, dissimular, esconder sentimentos, intenções, segredos etc. (ORTEGA, 2008a). Essa forma de subjetivação, que remete ao dualismo cartesiano e à tradição estoico-cristã, mas que fora realizada plenamente na cultura burguesa, assentava-se na ideia de que o "verdadeiro eu" era o eu interior, isto é, que as qualidades da substância cogitante, como o caráter e senso moral, o definiam. Resultando daí uma atitude geral de compreensão das complexidades sociais pelo privilégio de aspectos individuais, em uma espécie de narcisismo. Isso, de certo modo, corrobora o pensamento de Foucault (2013a, p. 11), principalmente quando esse afirma que o corpo humano é o ator principal de todas as utopias, "não há necessidade de uma alma nem de uma morte para que eu seja ao mesmo tempo opaco e transparente, visível e invisível, vida e coisa: [...] basta que eu seja um corpo".

É em oposição a essa tradição intimista - a qual não iremos nos deter aqui que a partir da segunda metade do século $X X$ irá surgir um novo modo de compreensão de nós mesmos. Nele, a natureza da vida psíquica, a identidade e todas as condutas éticas passarão a ser explicadas por meio de atributos físicos, químicos e neuroquímicos: "Corpo e self tornam-se idênticos" (ORTEGA, 2008a, p. 42). Das profundezas de uma interioridade, antes inacessível pelos métodos científicos, o self começa então a ser deslocado para a superfície visível do corpo, que "[...] inclui tanto o campo da normalidade quanto o da patologia" (ORTETA; ZORZANELLI, 2010, p. 66). No campo da normalidade estaria o homem considerado saudável, que passa a desenvolver uma série de preocupações físicas e estéticas, "[...] desde índices metabólicos até a busca de padrões de beleza e longevidade" (ORTETA; ZORZANELLI, 2010, p. 66). Em contrapartida, na esfera das patologias estariam as novas modalidades de sofrimento físico e mental, como os 
transtornos ligados à imagem corporal (anorexias e bulimias), depressões e adicções de todos os tipos. Em suma, a ideia de uma existência interior, pouco a pouco, começa a ser substituída por um self biologizado.

É dentro do contexto de uma cultura somática cada vez mais
acirrada que se desenvolve o processo de cerebralização da
identidade ou, em outras palavras, a construção da ideia de que o
cérebro e seu funcionamento definem exclusivamente as
propriedades pessoais dos seres humanos.
ZORZANELLI, 2010, p. 104).

Em meio à literatura neurobiológica do fim do século XX, por exemplo, encontramos várias obras que sugerem uma interpretação de nós mesmos enquanto selves somáticos. Entre elas podemos destacar $O$ homem que confundiu sua mulher com um chapéu, de Oliver Sacks (1997), que apresenta vários relatos de pacientes com distúrbios neurológicos afetando a imagem do "eu" - são histórias de pessoas que lutam para preservar a própria identidade, como a do Dr. P., que percebe, em virtude de um processo degenerativo nas partes visuais do cérebro, apenas formas geométricas ${ }^{49}$ e sons, não conseguia reconhecer o rosto da esposa nem de outros companheiros, mas os associava a notas musicais, era "fértil na produção de hipóteses cognitivas" (SACKS, 1997, p. 33). No mesmo livro, há relatos de pacientes que contam sobre sentir dores ${ }^{50}$ em membros que foram amputados, um assassino que não se lembra do próprio crime etc.

Outro livro bastante sugestivo é $O$ erro de Descartes, do neurologista António R. Damásio (1996), o qual oferece exemplos de pacientes que por causa de lesões cerebrais tiveram suas identidades radicalmente modificadas. Em um desses $\operatorname{casos}^{51}$, o de Phineas Gage $^{52}$, paciente do Dr. Harlow, temos que, ao sofrer uma forte lesão cerebral, Gage surpreendentemente conservou sua capacidade de fazer raciocínios lógicos, manteve a memória, consciência e linguagem intactas, mas, em contrapartida, ainda que tivesse sido um

\footnotetext{
${ }^{49}$ Dr. P. olha para os objetos e para as pessoas e é incapaz de identificá-las. Certa vez confundiu o próprio pé com seu sapato e a esposa com um chapéu.

${ }^{50}$ Fenômeno chamado de síndrome do membro fantasma.

${ }^{51}$ Nesse livro, o autor explora - sob a luz das tecnologias e dos conhecimentos neurocientíficos contemporâneos, analisando até mesmo as características do crânio de um paciente, Gage, obviamente em uma situação de pósmorte - o relato feito pelo médico John Harlow, ainda no século XIX, acerca de um acidente envolvendo uma explosão e a consequente lesão cerebral de Gage. "A narrativa de Harlow descreve o modo como Gage recuperou suas forças e como seu restabelecimento físico foi completo. Gage podia tocar, ouvir, sentir, e nem os membros nem a língua estavam paralisados. Tinha perdido a visão do olho esquerdo, mas a do direito estava perfeita" (DAMÁSIO, 1996, p. 28).

${ }^{52}$ Um trabalhador da construção civil do século XIX que sofrera um acidente e, mesmo tendo a parte frontal do cérebro trespassado por uma barra de ferro de um metro de comprimento e três centímetros de diâmetro, sobrevivera.
} 
trabalhador responsável e homem de "bom" caráter durante toda a sua vida, após o acidente tornou-se imprevisível, insensível e com grande dificuldade em tomar decisões, "mostrava-se agora caprichoso, irreverente, usando por vezes a mais obscena das linguagens" (DAMÁSIO, 1996, p. 28).

Com esses exemplos, nos quais não nos pretendemos prolongar, os autores tentam mostrar que aquilo que entendemos por nós mesmos, a nossa subjetividade, personalidade e senso moral, não é uma essência ou substância etérea perpetuável ad eternum, assim como o dualismo muitas vezes tentou provar, mas algo corporalmente mutável e suscetível, como diria Catherine Malabou (2014), a uma plasticidade destrutiva ${ }^{53}$, principalmente em razão de reconfigurações e transformações de natureza neural - provocada, por exemplo, por lesões em certas regiões do cérebro, tanto por acidentes como por causas patológicas.

No caso especial de Gage, Damásio (1996, p. 55) mostra que sua capacidade de tomar decisões, de se adequar às regras morais e o seu próprio caráter foram fortemente prejudicados por uma lesão dos córtices pré-frontais "nas superfícies ventral e interna de ambos os hemisférios". Qualquer um que anteriormente conhecesse Gage, segundo Damásio (1996), ao observar sua transformação, não seria capaz de dizer que ele era o mesmo, sua "natureza" havia se transformado em outra inteiramente diferente.

A partir daí, Damásio (1996, p. 27) intitula um dos tópicos de seu livro de "Gage deixou de ser Gage”, apontando para uma espécie de mudança na forma ontológica do próprio acidentado e dando a entender que $A *$ pode ser diferente de $A *$ se houver alguma interrupção ou mudança em sua estrutura cerebral, o que deixa em aberto também, via cérebro, uma espécie de incontrolabilidade da vida e um devir outro, em especial, movido por uma "catástrofe" do órgão intracraniano.

Seguindo essa trilha, Costa (2004) afirma que cinco fatores foram decisivos para a valorização do corpo na formação da identidade:

1. o desenvolvimento da ciência, principalmente na área da neurofisiologia, neurologia e disciplinas afins - neurociências e psicofisiologia;

2. os avanços das tecnologias médicas, como as técnicas neurorradiológicas e as leituras computadorizadas;

3. mudanças de ordem política - existiria uma tendência atual de a

\footnotetext{
${ }^{53}$ Retomaremos esse assunto no capítulo 4.
} 
sociedade deslocar-se dos temas tradicionais do debate político, como conflitos de classe, conflitos entre Estado e sociedade, entre blocos ideológicos, econômicos, entre outros, para questões circunscritas a partes específicas da esfera social, como conflitos raciais, sexuais ou geracionais $^{54}$;

4. mudanças de ordem espiritual - a religiosidade ocidental estaria passando por importantes transformações, permitindo a inclusão de elementos de doutrinas espirituais de regiões como a Índia, Tibet, China, Japão, entre outras, na formação dos ideais do "eu";

5. e, por último, e talvez a mais importante, uma mudança na ordem intelectual - haveria atualmente uma recusa da divisão cartesiana entre mente e corpo, protagonizada principalmente por teorias como a fenomenologia, o reducionismo fisicalista, a heterofenomenologia e o pragmatismo linguístico, bem como a defesa de uma concepção holística ou ecológica da vida mental, tal como feita por Gibson (1986) e Maturana e Varela (2004).

Esses fatores, e outros, como o sofrimento "psíquico" - depressões, transtornos de comportamento, síndrome do pânico etc. -, em linhas gerais, possibilitaram um remapeamento cognitivo do corpo físico. O corpo deixou de ser um autômato ou uma substância secundária na definição da identidade - se comparada à substância pensante - e passou a unir teoricamente fenômenos concretos, como o físico e o mental, ressurgindo como o verdadeiro locus da concretude: "O corpo físico, até então reduzido ao silêncio da saúde ou ao ruído da doença, se mostra, agora, loquaz em suas demandas: ele intenciona, age, conhece, sente, julga e, se soubermos escutá-lo, 'fala'” (COSTA, 2004, p. 214). Desse modo, a visão dualista de mundo ficou como que relegada a um debate histórico-filosófico, ainda que aparentemente inesgotável; no entanto, no mundo das práxis os processos corpóreos e mentais começaram a ser compreendidos de forma monista ou, ainda, dentro de relações estritamente causais.

\footnotetext{
${ }^{54}$ De certa forma, outros autores já teriam apontado para o fato de que a ação política estaria fundamentando-se, em detrimento das relações imateriais (ARENDT, 2010), na materialidade biológica ou, ainda, na "vida nua" (AGAMBEN, 2002), e as referências corpóreas estariam substituindo a referência cultural e dando origem a uma biossossiabilidade (RABINOW, 1999).
} 
A consequência disso tudo parece ter sido a disseminação de uma cultura somática, na qual a otimização corporal se transformou em medida de valor, os modelos identitários passaram a fundamentar-se em parâmetros de saúde e performance física, as emoções e as condutas começaram a ser associadas a configurações fisiológicas, moduláveis pela ação sobre a química cerebral, e a personalidade tornou-se um sítio aberto a interferências mecânicas e modificações farmacológicas de todos os tipos. Os signos de uma política da vitalidade, nesse contexto, como veremos, começaram a adequar-se a esse processo de somatização da identidade - principalmente no que se refere à sua alocação -, agora racionalmente (ou acidentalmente) modificável na lógica da economia.

Associada a isso, a cultura somática vem sendo marcada também por uma exibição voluntária do corpo e da intimidade, testemunhada pelas tecnologias comunicacionais. De certa forma, as pessoas passaram a buscar, contemporaneamente, o olhar do outro, a desejar a visibilidade e a transparência em oposição às práticas de recolhimento e privacidade que caracterizaram a sociedade intimista: "Hoje, sou o que aparento e estou, portanto, exposto ao olhar do outro, sem lugar para me esconder, me refugiar; estou totalmente à mercê do outro, já que o que existe (o corpo que é também o self) está à mostra" (ORTEGA, 2008, p. 44). Nessa direção, ocorre uma espécie de substituição de uma tirania da intimidade, cujo efeito principal foi o enfraquecimento do espaço público, por uma da aparência, que, a despeito da ação política e das referências culturais, reduziu o social ao biológico.

O self superficial, paranoico e melindroso tem uma única maneira de escapar da tirania da aparência: se igualando, se conformando à norma. Somente sendo idênticos à norma é que podemos nos esconder. A adaptação, a obediência e a identificação com a norma é o refúgio do eu que fez de sua aparência a essência. Queremos ser iguais para nos protegermos, nos escondermos. Ou somos idênticos, ou nos denunciamos. (ORTEGA, 2008, p. 45)

É nesse cenário de transformações e/ou mudanças identitárias que as pessoas começam a dizer "O corpo pensa" ou, ainda, "Você é o seu cérebro". No entanto, cabe aqui um pequeno esclarecimento, especialmente no que diz respeito à

\footnotetext{
${ }^{55}$ A despeito da normalização e dessa tirania da aparência, podemos pensar ainda, é claro, em uma estilística de existência que não se conforma à regra, ou em formas de vida que são tidas como desvios, mesmo que não sejam construídas arbitrariamente.
} 
distinção entre cérebro e pensamento, ou cérebro e mente. O cérebro, na maioria das vezes, é considerado o órgão fundamental do sistema nervoso, que oferece suporte biológico para a discriminação das informações do ambiente e, ao ser estimulado, produz as respostas mais adequadas. A mente seria o conjunto de funções superiores do cérebro: inteligência, emoção, memória, pensamento, aquilo que garante a própria identidade do sujeito. A questão é que, apesar da existência de uma longa tradição filosófica debatendo o problema da relação mente/corpo ${ }^{56}$, ou mente/cérebro, muitas vezes fazendo uma distinção radical entre substância ou propriedade mental e corpo, a posição que vai ser colocada pela cultura somática, pelas práticas de cerebralização da identidade, é uma espécie de equação entre cérebro e mente.

\subsubsection{Um aparte sobre a construção do sujeito cerebral}

É importante notar que desde o fim do século XVIII, mesmo na época da cultura intimista, já haviam esforços sistematizados para localizar no cérebro questões relacionadas à identidade. Vemos isso, por exemplo, nos trabalhos desenvolvidos pelos teóricos da frenologia ${ }^{57}$ (de phrenos = mente), que acreditavam ser possível determinar características de personalidade pelo formato do crânio, e também pelos teóricos localizacionistas, que, a exemplo de Pierre Paul Broca (1824-1880) e Carl Wernicke (1848-1905), identificaram disfunções de linguagem, como a afasia, pesquisando lesões ${ }^{58} \mathrm{em}$ áreas específicas de um dos hemisférios cerebrais, o esquerdo, no qual

\footnotetext{
${ }^{56}$ Se a mente for concebida como substancialmente distinta do corpo, cabe explicar como é possível e como se dá a interação causal entre ambos; se ela for concebida como corpórea, cabe explicar por que e como o corpo é dotado de mente.

${ }^{57}$ A frenologia foi desenvolvida por Franz Joseph Gall (1758-1828) e popularizada por Johann Spurzheim (17761832). Apesar de desacreditada em razão de problemas específicos, como a impossibilidade de esculpir "faculdades" em entidades distintas e provar que a forma do crânio correspondia à forma do cérebro, terminou por influenciar posteriormente vários teóricos localizacionistas, a exemplo: Gustav Fritsch, Eduard Hitzig e até mesmo o criminologista Cesare Lombroso, que acreditava ser possível diagnosticar a criminalidade com base nas características faciais de um indivíduo.

${ }^{58}$ Grande parte das pesquisas localizacionistas desenvolvidas no século XIX, e em parte do século XX, fundamentou-se em estudos de lesões cerebrais. De acordo com Steven Rose (2006), algumas dessas pesquisas foram obtidas de forma deliberada, geralmente estudando pássaros, gatos e cachorros, e mais tarde sendo buscadas outras alternativas, como lesões causadas em seres humanos por acidentes ou em situação de guerra. Um exemplo histórico de lesão por acidente, antes comentado mas que vale aqui ser ressaltado, é o de Phineas Gage, operário norte-americano do século XIX que teve seu cérebro trespassado por uma barra de ferro e, mesmo assim, não morreu em consequência desse evento. Mais tarde, já no fim do século XX, o seu caso foi retomado pelo neurocientista António R. Damásio, que descreveu as impressões de pessoas no entorno de Gage logo após o acidente. Uma dessas impressões é bastante emblemática: "Gage deixou de ser Gage" (DÁMASIO, 1996, p. 27).
} 
acabaram por constatar, além de uma assimetria hemisférica, o centro de toda a fala. Temos ainda, do fim do século XIX até metade do século XX, pesquisas que trataram o cérebro como um órgão holístico, como as realizadas por John Hughlings Jackon (1835-1911), Pierre Marie (1853-1940) e até mesmo Sigmund Freud (1856-1939), para os quais a organização cerebral dos processos mentais complexos devia ser abordada do ponto de vista do nível da construção de tais processos, em vez do da localização em áreas do encéfalo, e é nesse período que também aparece a "doutrina neural".

Os frenologistas, por exemplo, chegaram a propor, a partir do fim do século XVIII fundamentados em análises de dimensões, protrusões e depressões da superfície exterior do crânio -, diretrizes de como os indivíduos deveriam conduzir sua vida, afirmando: "[...] no cérebro residem as respostas práticas às mais diversas questões, desde como desenvolver talentos pessoais; em quem confiar [...], como educar crianças; questões de educação sexual e até a escolha do cônjuge ou dos melhores empregados" (ORTEGA, 2009a, p. 628). Grosso modo, esses estudiosos criaram um mapa topológico das faculdades mentais e morais dos indivíduos, em que cada aspecto da vida social e pessoal poderia ser abordado e classificado.

Quanto aos localizacionistas, ao descobrirem uma assimetria entre os hemisférios cerebrais, acabaram por motivar no âmbito educacional a prática do ambidestrismo ${ }^{59}$ (AZAMBUJA, 2012), por meio do qual se acreditava que era possível duplicar a capacidade cerebral das pessoas, tornando-as mais inteligentes, além de prevenir e corrigir possíveis danos ao órgão. Esses trabalhos deram início, ou pelo menos influenciaram, aos primeiros programas de neuroeducação e neuróbica. E foi em meio a esse debate frenologista, localizacionista e também antilocalizacionista que apareceu entre o fim do século XIX e início do século XX a referência a uma doutrina neural, proposta pelo espanhol Santiago Ramón y Cajal (1852-1934), denominada mais especificamente de teoria neuronista (AZIZE, 2010), que ainda hoje tem fundamentado os saberes em neurociência.

Vemos, então, que a ideia de um sujeito cerebral, apesar de aparentemente nova, já vinha aos poucos sendo formulada, já havia um ensaio ${ }^{60}$ para dizer "Você é o seu cérebro", com tentativas de equalizar o mental e o cerebral, além de esforços disciplinares e de hierarquização dos indivíduos tomando como ponto de referência suas características encefálicas. No entanto, a cristalização ou a formulação da ideia de um sujeito cerebral em

\footnotetext{
${ }^{59}$ Método educativo que tinha por objetivo fazer com que as pessoas utilizassem, indiferentemente, as duas mãos.

${ }^{60}$ Segundo Vidal (2011), a ideia de que somos essencialmente o nosso cérebro já vinha sendo construída desde o fim do século XVII, sobretudo pelas filosofias da matéria e da identidade pessoal.
} 
uma versão forte só vai acontecer, segundo Ehrenberg (2009) e Vidal (2011), na segunda metade do século XX, principalmente por meio das neurociências ${ }^{61}$ e das tecnologias de imageamento $^{62}$, especialmente as funcionais, que permitiram “[...] observar o cérebro enquanto ele funciona como mente - pensando, recordando, vendo, ouvindo, imaginando, experimentando prazer ou desagrado" (ANDREASEN, 2003, p. 158), complementando ${ }^{63}$ os estudos tradicionais sobre o funcionamento do cérebro humano que eram realizados majoritariamente em situações de lesões e pós-morte.

Apesar da consciência de que os estudos neurobiológicos têm uma longa tradição e, ao mesmo tempo, procurando nos adequar às finalidades ${ }^{64}$ deste trabalho, nos deteremos aqui, rapidamente, apenas em alguns apontamentos introdutórios feitos por Ehrenberg (2009) sobre essas ciências, especialmente no que diz respeito a algumas possibilidades então desencadeadas a partir da segunda metade do século XX. Desse modo, segundo o autor, as neurociências se ofereceram, inicialmente, como aporte científico, tecnológico e médico para responder à demanda da saúde mental que se difundiu em nossas sociedades nos últimos quarenta anos. Interessaram-se, a princípio, por questões relacionadas à motricidade, à experiência sensorial, aprendizagem e doenças neurológicas (Alzheimer, Parkinson), o que caracterizou, segundo Ehrenberg (2009), uma espécie de versão "fraca". No entanto, a partir dos anos de 1980, as neurociências promoveram transformações significativas na área médica. Por um lado, começaram a abordar doenças neurológicas e mentais como uma única patologia, como é o caso da esquizofrenia, e, por outro, o perímetro de ação de suas múltiplas interfaces estendeu-se também às emoções, aos comportamentos sociais e aos sentimentos morais. Surgindo, nessa direção, uma versão "forte" que passou a identificar o conhecimento

\footnotetext{
${ }^{61}$ A neurociência emerge nas múltiplas interfaces entre medicina, biologia, psicologia e filosofia, ocorridas na década de 1960. "Sua base racional originária deve ter sido as tentativas para tratar ou mitigar danos cerebrais explícitos, supostamente causados por ferimentos na cabeça” (ROSE, 2006, p. 211). Para alguns pensadores, como Gerald Edelman (1995), o social, o cerebral e o mental serão fundidos nessa nova ciência "rainha".

${ }_{62}$ Tomografia computadorizada, ressonância magnética - que são as mais antigas das novas técnicas de imagiologia, datando, respectivamente, das décadas de 1960 e 1980 - e também as técnicas funcionais, como a tomografia computadorizada por emissão de fóton único, ressonância magnética funcional e a tomografia por emissão de pósitrons.

${ }^{63} \mathrm{Com}$ as técnicas de imageamento cerebral, um amplo campo de características mentais passou a ser mapeado, tais como experiências de vida, o impacto do ambiente e do aprendizado, experiências místicas, comportamentos antissociais e até mesmo o substrato biológico de atitudes como o racismo. Nessa direção: "As neuroimagens funcionais parecem fornecer diagnósticos visuais e nos dizer por que somos como somos. Elas se tornaram fotografias do self" (ORTEGA; VIDAL, 2007, p. 259). Se, no período de domínio da interioridade metafísica, o "eu" só podia ser capturado por uma análise introspectiva, agora, com as técnicas de neuroimagens, acredita-se que o "eu" se tornou transparente, que pode ser percebido por meio da visualização de fluxos sanguíneos no cérebro.

${ }_{64}$ No momento, a finalidade é fazer alguns apontamentos sobre a emergência do sujeito cerebral, mas, posteriormente, será o de analisá-lo no contexto da biopolítica contemporânea, principalmente no que se refere às tentativas de potencializá-lo e colocá-lo à disposição da lógica do Homo oeconomicus.
} 
do cérebro com o conhecimento de si mesmo, dizendo "Você é seu o cérebro" e, no plano clínico, acreditando "[...] poder fundir neurologia e psiquiatria, quer dizer [...] tratar as psicopatologias neuropatologicamente e, talvez num prazo mais longo, agir mais eficazmente sobre a nossa maquinaria cerebral para aumentar a nossa capacidade de decisão e ação (EHRENBERG, 2009, p. 189, grifo nosso).

Assim, além de sinalizarem para uma espécie de agenciamento das formas psi e da explicação das condutas sociais pela biologia, ou neurobiologia (transformando os "psis" em "neuros"), as neurociências, em sua versão forte, tornaram-se também agentes propagadoras de uma cultura da promessa, começaram a enfatizar, para além da correção, um ideal de otimização do ser humano: "agir mais eficazmente", "aumentar a capacidade de decisão e ação", "produzir cérebros melhores", "aumentar a inteligência", "potencializar a memória e a atenção" etc. O que de certa forma corrobora o discurso da governantalidade neoliberal, tal como apresentado por Foucault (2008b). Nele, como vimos, as competências, as habilidades e as aptidões dos indivíduos passaram a constituir o seu próprio capital, e nesse cenário é fácil imaginar que "cérebros melhores" constituam também os melhores capitais.

Uma lista de verificação conveniente é dada pela edição especial do Scientific American, de setembro de 2003, intitulada "Cérebros melhores: como a neurociência pode melhorar você". Na capa havia um sumário dos temas que o artigo tinha a intenção de cobrir: "Máximo automelhoramento; Novas esperanças para reparos do cérebro; A busca de uma pílula inteligente; Estimuladores do cérebro; Domínio do estresse; Máquinas que leem a mente; Genes e psique", e ineditamente, por último, "Neuroética". O conselho de bioética do presidente dos Estados Unidos tinha uma lista um tanto diferente: "A busca da felicidade; filhos melhores; Desempenhos superiores; Corpos sem idade; Almas felizes". Então, o que está por trás desses cabeçalhos? (ROSE, 2006, p. 292).

Para dar clareza ao debate, Ehrenberg (2009) complementa dizendo que dentro da versão forte das neurociências é possível evidenciar três perspectivas:

1. teórica, notadamente marcada por um reducionismo fisicalista que postula o cérebro como o "fundamento" de todos os estados mentais;

2. prática (profissional e terapêutica), compreendida no contexto das doenças psíquicas e das preocupações com a saúde mental, que tenta aproximar neurologia e psiquiatria ou as deficiências da mente com as do cérebro; e

3. social, toma o cérebro como referência para compreender e descrever as condutas humanas, desde a aprendizagem, passando por escolhas morais, 
propensão ao crime e até questões relacionadas à fé religiosa.

Ao evidenciar, em especial, essa última perspectiva, as neurociências contribuíram, então, para que o cérebro deixasse de ser um objeto de interesse exclusivo da ciência para tornar-se também um "ator social” (EHRENBERG, 2009).

A questão é que, apesar de toda a história e seriedade dos trabalhos em neurociências - os quais não pretendemos questionar nem mapear -, ao promover o cérebro a "ator social", o programa forte das neurociências acabou por expulsá-lo do seu espaço laboratorial, o que colaborou para que uma linguagem cerebralista se difundisse em meio à vida cotidiana e se articulasse com outras áreas do conhecimento, dando origem a saberes híbridos, como a neuropsicanálise, neuroteologia, neuroética, neurodireito, neurofilosofia, neuroeducação etc. Saberes que discursam, afirmando, por exemplo:

[...] a pesquisa realizada sobre algumas questões necessárias ao conhecimento de todo educador revela claramente que a "alfabetização" em Neurociência se reveste de suma importância para o cotidiano escolar, na medida em que, só a partir da compreensão do homem como um ser biopsicossocial, tornará possível uma intervenção pedagógica mais eficaz, centrada no aluno. (TEIXEIRA, 2017, p. 173, grifo nosso).

Assim, o cérebro começou a ocupar um lugar privilegiado na representação da identidade e subjetividade do sujeito e, mais ainda, tornou-se motivo de expectativas para a construção de um "admirável mundo novo"65 não apenas entre (neuro)especialistas, mas também entre leigos, empresários, religiosos e mesmo entre educadores, muitas vezes movidos por um ideal de melhoramento da performance mental ou da correção de comportamentos "indesejados" de seus aprendizes.

Então, na mesma direção de Andreasen (2003), que afirma esperar animadamente por uma "penicilina" para as doenças mentais, muitos outros esperam, por meio de interferências cerebrais (mecânicas e/ou farmacológicas), promover o desenvolvimento pessoal, o sucesso profissional $^{66}$, a correção da atenção, a potencialização da criatividade, o aumento na capacidade de raciocínio lógico, melhorar a autoestima, a disciplina, a perseverança etc. A

\footnotetext{
${ }^{65}$ Parafraseando Aldous Huxley (1894-1963), Andreasen (2003) intitulou seu livro de "Admirável cérebro novo".

${ }^{66}$ Nesse contexto, são propagadas literaturas que vão desde trabalhos de neurocientistas até publicações de autoajuda, muitas vezes fundamentadas, como afirma Ehrenberg (2009), na ideia de um "cérebro emocional" que é considerado "o cérebro do cérebro" (insensível à cognição e à linguagem). O princípio básico dessa literatura de autoajuda é de que é possível reprogramar o cérebro emocional e aumentar a sua capacidade. Nessa mesma direção, escolas de ginástica cerebral, como a rede Supera, no Brasil, também ganham bastante espaço.
} 
versão forte das neurociências colaborou, então, com a disseminação de um discurso e de uma ideologia do sujeito cerebral segundo a qual o cérebro aparece "[...] como o órgão material por excelência, como a única parte de nossos corpos físicos que realmente vale a pena exercitar para melhorar a nós mesmos" (ORTEGA; VIDAL, 2007, p. 260).

Essa constatação parece interessante, pois, se pensarmos na lógica do homo oeconomicus e/ou na máxima neoliberal de que o homem deve ser um "empresário de si mesmo", tal como apontado por Foucault (2008b), o cérebro torna-se, em consequência, o principal atrator no processo de produção de capital humano e, além disso, o novo local de manifestação da verdade sobre o próprio sujeito contemporâneo.

No entanto, antes de entrarmos nesse assunto, vale a pena destacar que a valorização social do cérebro, assim como constatada por Ehrenberg (2009), apresenta-se como uma possibilidade de resposta a problemas formulados por um ideal de autonomia individual generalizada. No cérebro se concentraria a esperança atual de uma solução técnica para os sofrimentos decorrentes das exigências relativas às capacidades cognitivas e de controle emocional, e sob a perspectiva cerebralista uma desestigmatização da incapacidade social também estaria ocorrendo, principalmente mediante a substituição da ideia de deficiência pela noção de neurodiversidade ${ }^{67}$ : "Os disabilities movements promovem uma nova linguagem da incapacidade social, reivindicando a tolerância e o direito à diferença, apoiados sobre a referência ao cérebro" (EHRENBERG, 2009, p. 203). Ilustrando essa nova situação, temos que:

\begin{abstract}
Atualmente, laudos de dislexia servem como aval para que jovens tenham tratamento diferenciado em escolas e até mesmo no vestibular. C.S.A. (que pede para não se identificar), reprovado várias vezes em vestibulares, depois de um laudo médico que comprovava sofrer de dislexia obteve a autorização de algumas instituições para fazer seu exame de forma diferenciada - com mais tempo para as provas e com a presença de alguém que lê as questões e auxilia na conferência dos gabaritos. Com esses recursos, ele foi aprovado em várias universidades públicas importantes, como UNESP, USP e UFMG. Optou pelo curso de Geologia na UNESP de Rio Claro, estado de São Paulo. (CORREIA; OLIVEIRA, 2013) ${ }^{68}$.
\end{abstract}

Com isso, podemos visualizar, mesmo que rapidamente, sinalizações a respeito de algumas consequências sociais promovidas pela emergência do sujeito cerebral. Em meio a

\footnotetext{
${ }^{67}$ Estariam incluídos nessas representações o autismo, o TDAH, a síndrome de Tourette (“a doença dos palavrões"), e outras.

${ }^{68}$ Disponível em: http://www.redebrasilatual.com.br/revistas/64/saude. Acesso em: 28 abr. 2018.
} 
esse debate, algo que ainda pensamos merecer destaque é o fato de o cérebro ter sido alçado à referência, talvez uma das principais, da biopolítica contemporânea. Os olhos do poder passaram a fitá-lo diretamente, e por meio dele novas formas de condução do sujeito, ou de subjetivação, entraram em jogo. Humores, emoções, volições, memória e inteligência tornaram-se motivos de investimento científico, econômico e político. A racionalidade neoliberal começou a cultivar e demonstrar interesse pela maximização dos estados mentais/cerebrais (a proliferação dos chamados neuronegócios e o surgimento de uma nova forma de sociabilidade, a neurossociabilidade, sinalizam muito bem isso - ORTEGA, 2009b), indicando uma nova frente de subjetivação e produção de capital humano.

A seguir, discutiremos algumas das características daquilo que Rose (2013) denomina de biopolítica contemporânea e, a partir daí, lançaremos alguns exemplos de investimentos e saberes que tomam como referência a figura do sujeito cerebral. Nas sociedades liberais contemporâneas, como observará Rose (2013), surgiram novos saberes acerca do que somos, entre os quais a própria ideia de uma identidade cerebral. Esse acontecimento, por sua vez, indica inflexões nos regimes de verdade que os novos vetores sociais e as novas formas de exercício do poder vêm colocando em movimento.

\subsection{A BIOPOLÍTICA NO SÉCULO XXI}

O poder, como muito bem observara Foucault (2014), desde o século XVII é exercido no nível da vida, isto é, a vida mesma se transformou em objeto político. Tanto as características vitais dos indivíduos, como as que podem ser vigiadas, treinadas, docilizadas e aumentadas, quanto as da coletividade, que podem ser normalizadas, tornaram-se alvos de investimento, entraram em um cálculo de interesses políticos, científicos e econômicos. No entanto, é importante observar que a política da vida nem sempre se manifestou da mesma forma e com a mesma intensidade sobre os mesmos elementos vitais, o seu campo de atuação sofreu mutações, principalmente por causa dos avanços tecnológicos e científicos, de novas tecnologias e racionalidades de governo e também em razão de mudanças na concepção do que é o ser humano.

Atentando para isso, Nikolas Rose (2013) refere que a política da vida dos séculos XVIII e XIX, por exemplo, foi uma política da saúde - das taxas de nascimento e de morte, de doenças e epidemias, do policiamento da água, de saneamento, gêneros alimentícios, cemitérios e da vitalidade dos aglomerados urbanos -, incrementada, na primeira metade do 
século XX, por uma compreensão particular da herança de uma constituição biológica e das consequências da reprodução discriminatória de diferentes subpopulações, o que ocasionou, politicamente, uma administração higienista da população “[...] muitas vezes coercitivamente e, às vezes, mortiferamente, em nome do futuro da raça” (ROSE, 2013, p. 16). Porém, o autor observa que a política da vida do nosso século é diferente. Ela não está delimitada nem pelos polos de doença e saúde, nem concentrada em eliminar patologias para proteger o destino da nação: "Ao contrário, está preocupada com nossas crescentes capacidades de controlar, administrar, projetar, remodelar e modular as próprias capacidades vitais dos seres humanos enquanto criaturas viventes" (ROSE, 2013, p. 16). Por isso, o mesmo autor sugere tratar-se de políticas da vida ela mesma (politics of life itself).

A particularidade dessa política é explicada, em parte, pelas mudanças nas racionalidades e tecnologias de governo que, em primeiro lugar, como aponta Rose (2013), transferiram a responsabilidade da segurança, do bem-estar social, da reprodução humana e da saúde do aparato formal de governo para entidades regulatórias quase autônomas, como comissões de bioéticas, clínicas privadas de fertilidade, companhias de biotecnologia e grupos de profissionais especializados. E, em segundo lugar, enfatizaram a responsabilidade dos indivíduos na autogestão da vida, principalmente com questões relacionadas à saúde. As pessoas deixaram de se comportar como meros pacientes para tornarem-se consumidores ativos de serviços médicos e de produtos de toda ordem, desde remédios que prometem aumentar a inteligência humana, como as chamadas "drogas espertas", passando pela implantação de próteses, até as tecnologias de reprodução.

Ademais, o campo de novidade dessa biopolítica, diferentemente dos parâmetros de sexualidade e procriação, parece estar no espaço de problemas relacionados à otimização ${ }^{69} \mathrm{da}$ vida (ROSE, 2013). Aos poucos o corpo humano torna-se o locus de uma sofisticada operação identitária, cujo foco principal é um processo de contínuo aprimoramento, há “[...] um crescimento qualitativo em nossas capacidades de manipular nossa vitalidade, nosso desenvolvimento, nosso metabolismo, nossos órgãos e nossos cérebros” (ROSE, 2013, p. 17), o que, de alguma forma, alimenta as expectativas de uma nova condição humana.

Essa otimização, em linhas gerais, faz parte de um conjunto de transformações que vem remodelando a percepção e a prática biomédica, causando mutações na política,

\footnotetext{
${ }^{69}$ Está claro que, a despeito dessa constatação, a ideia de um poder que é exercido de forma positiva e que potencializa a vida já estava presente na análise de Foucault, principalmente quando comenta sobre o deslocamento do "direito de fazer morrer" para o "poder de fazer viver". A novidade, no entanto, parece ser a da mudança de escala, a vida passou a ser administrada no nível molecular.
} 
produzindo novas tecnologias de governamentalidade, novas formas de autoridade e de expertise e desencadeando novos processos de subjetivação. Estamos, como ressalta Rose (2013, p. 15), diante de "uma forma de vida emergente", caracterizada, essencialmente, por mudanças quantitativas e qualitativas em certo número de dimensões, entre as quais merecem ser destacadas: movimentos de molecularização, tecnologias de otimização, subjetivação, expertise e bioeconomia.

A primeira dimensão, a molecularização, diz respeito a um deslocamento na escala de compreensão da vida, de "mol” para molecular, acompanhado por uma mudança no estilo de pensamento que inclui, além de discursos especializados, técnicas sofisticadas de manipulação e reprogramação molecular, como a fabricação personalizada de sequências de DNA. Nesse novo contexto, "O laboratório tornou-se um tipo de fábrica para a criação de novas formas de vida molecular. E, ao agir assim, está fabricando uma nova forma de compreensão da vida" (ROSE, 2013, p. 27-28). Isso significa que a vida mesma, em tese e na prática, não está mais limitada à normatividade de uma ordem natural, ela pode sofrer todo tipo de intervenções, desde correções prévias de distúrbios considerados hereditários, como é o caso de algumas doenças cardiovasculares, até possíveis aprimoramentos por meio de manipulação genética. Além disso, as atuais intervenções moleculares procuram atingir o organismo, para além dos espaços laboratoriais, também quando estão em "funcionamento", atuantes. Esse é o caso da interferência medicamentosa em neurotransmissores ${ }^{70}-$ feita com antidepressivos produzidos através do conhecimento personalizado das informações genéticas. Aliás, atualmente é cada vez mais comum ouvirmos as pessoas falando de si mesmas, de suas alegrias e tristezas, e isso no que diz respeito a equilíbrio e desequilíbrio nos neurotransmissores.

O processo de molecularização da vida vem encontrando o apoio de que necessita nas tecnologias de visualização, principalmente nas que atuam por meio de simulação digital e modelização matemática. Dawkins (2005), que acompanhou de perto muitas das pesquisas em genômica, curiosamente afirma que o próprio código genético é digital, exatamente no mesmo sentido que os códigos dos computadores. De acordo com o autor, todo o universo molecular poderia ser convertido em um ramo da informática.

\footnotetext{
${ }^{70}$ Os neurotransmissores são pequenas moléculas responsáveis pela comunicação das células no sistema nervoso, sendo elas, em sua maioria, provenientes de precursores de proteínas e comumente encontradas nos terminais sinápticos dos neurônios. Estão envolvidos em muitos comportamentos, como aprendizagem, memória, atenção, volição, sono, humor etc. Existem diversos tipos de neurotransmissores, os mais conhecidos são: acetilcolina, serotonina, noradrenalina, dopamina, entre outros.
} 
[...] a sub-rotina de um software (que é exatamente o que um gene vem a ser) pode ser copiada $(\mathrm{Ctrl}+\mathrm{C})$ de uma espécie e colocada $(\mathrm{Ctrl}+\mathrm{V})$ em outra, onde ela funcionará exatamente da mesma maneira que na espécie original. É por isso que o famoso gene "anticongelante", originalmente desenvolvido pelos peixes do Ártico, pode salvar um tomate dos efeitos de uma geada. Assim também, um programador da NASA que necessite utilizar uma rotina em seu sistema de orientação de foguetes para o cálculo preciso de raízes quadradas pode importá-la de um programa de análise financeira. (DAWKINS, 2005, p. 56).

Assim, tal como um software que pode ser processado em diferentes hardwares, as informações moleculares podem ser transportadas de um organismo a outro: “A molecularização despe tecidos, proteínas, moléculas e remédios de suas afinidades específicas - com uma doença, um órgão, um indivíduo, uma espécie - e capacita-os a serem vistos [...] como elementos ou unidades manipuláveis e transferíveis" (ROSE, 2013, p. 30). Com isso, a molecularização estaria dando uma maior mobilidade aos elementos da vida e possibilitando a formação de novos circuitos de vitalidade.

Um segundo elemento na análise da biopolítica contemporânea diz respeito ao desenvolvimento de tecnologias de otimização, principalmente as que são produzidas por biólogos, biomédicos, engenheiros, matemáticos e peritos em informática interessados em compreender e "controlar o processo vital dos corpos e da mente" (ROSE, 2013, p. 32). Esses profissionais trabalham em conjunto buscando determinar, por exemplo, as sequências de DNA e as proteínas que constituem a estrutura corpórea. Ao combinar componentes básicos dos sistemas biológicos, muitas vezes por meio de técnicas de simulação computacional, eles tentam “[...] prever estados vitais futuros e, por conseguinte, possibilitar intervenção naqueles sistemas vitais para remodelar aqueles futuros" (ROSE, 2013, p. 32). Nesse cenário, o que se verifica é uma espécie de mudança epistemológica fundada essencialmente na possibilidade de remodelar a identidade do ente biológico calculando e manipulando seus processos vitais e, em consequência, maximizando e incrementando seu funcionamento e resultados.

Dessa forma, ao contrário da medicina tradicional, que procurava restabelecer a normatividade dos corpos, as tecnologias de otimização promovem, na atualidade, uma mudança nas próprias normas naturais da vida $^{71}$. Elas são responsáveis, entre outras coisas, pela reconfiguração dos humores, da atenção, da inteligência, remodelam a capacidade de procriação, transpõem as normas de envelhecimento por meio de terapias de reposição hormonal, prorrogam o tempo de vida sexual do homem com o uso de medicamentos, reconfiguram o corpo por meio de cirurgias plásticas, prolongamento de membros,

\footnotetext{
${ }^{71}$ Fazem isso tanto em termos de "mol" quanto no nível molecular.
} 
redesignação sexual etc. Enfim, tendem a mudar muitas das características consideradas como naturais nos seres humanos ${ }^{72}$.

Em meio às tecnologias de otimização, Rose (2013) destaca duas dimensões que parecem fundamentais para a demarcação da biopolítica atual: a susceptibilidade e o aprimoramento. Na primeira, existe uma política de saúde ${ }^{73}$ que identifica e trata os indivíduos no tempo presente com vistas a patologias que, probabilisticamente, podem vir a desenvolver no futuro ${ }^{74}$. Trata-se, de certo modo, do cuidado com aquilo que Foucault (2008b) chama de capital humano hereditário. É também uma forma de evitar que, de acidentes genéticos, por exemplo, emerjam acontecimentos/vidas ingovernáveis.

Fundamentados em "tecnologias do devir", especialistas da susceptibilidade promovem uma espécie de cálculo e controle de risco $^{75}$ e oferecem instrumentos e informações para o exercício de um novo poder pastoral. Em vez de "disciplinar e punir", esse tipo de poder está mais preocupado em "triar (screen) e intervir" (ROSE, 2010, p. 213), constituindo formas de controle molecular do corpo e de governo da população.

Nosso Primeiro Ministro [da Inglaterra] disse que o Sistema Nacional de Saúde sempre foi voltado às doenças; mas deveria ser um serviço de saúde. Um serviço de saúde nesse sentido implica screen suscetibilidades para doenças, identificar condições cedo, antes de se manifestarem, e então intervir de modo a prevenir que se manifestem. [...] E se tivermos screening crianças para detectar problemas comportamentais futuros e intervindo cedo, temos uma grande quantidade de argumentos sociológicos, psicossociais bastante convencionais a respeito do que podem ser as implicações para a gurizada. Acrescente-se a isso o fato de que estamos em um mundo de precaução; iremos superalargar nossa rede ao invés de restringir nossa rede. $\mathrm{E}$, em resposta à sua pergunta ${ }^{76}$, como interviremos, bem, pode-se retreinar as mães - em geral são as mães! - ou pode-se intervir com os fármacos. (ROSE, 2010, p. 313-314).

\footnotetext{
${ }^{72}$ Dos animais, em geral, e das plantas também.

${ }^{73}$ Essa política da saúde, fundamentada na susceptibilidade, não é acessível para todos. Existe aqui um fator econômico: os que têm e os que não têm dinheiro para pagá-la.

${ }^{74}$ De acordo com Ribeiro (2003), cogita-se mesmo curar, já no feto, doenças que um dia o indivíduo possa vir a desenvolver.

${ }^{75}$ Rose (2013) adverte que a noção de risco, antes entendida como periculosidade, passou a ser compreendida como probabilidade de desenvolver transtornos. O que era tomado como incerto e imprevisível, ao passar pelo filtro das ciências biológicas e neurológicas, tornou-se rastreável e objeto de investimentos e controle. Desse modo, a noção de suscetibilidade se desenvolve em apoio a uma gestão biopolítica de certos fenômenos que antes eram considerados como "ingovernáveis".

${ }^{76}$ Trecho de entrevista realizada por Mary Jane P. Spink, no BIOS Centre, em 19 de novembro de 2008, a pergunta a que se refere é: "Pensando, por exemplo, em poderes pastorais, como lidar com as pessoas de modo preventivo quando se trata do cérebro, do novo cérebro neuroquímico? O que é a promoção da saúde nesse contexto? Uma vez que seu filho tem um problema, posso entender como pode ser tratado; mas como lidar com o lado preventivo, o lado promocional" (ROSE, 2010, p. 313).
} 
Ao identificar (triar) um componente molecular de uma patologia, por exemplo, uma informação genética, mesmo que nenhuma doença tenha ainda se manifestado, o indivíduo se obriga (ou é obrigado) a fazer um tratamento preventivo, pois ele é tido como um "prépaciente". Com isso, o que ele deve fazer, esperar e pensar é recodificado de acordo com a sua corporeidade. Apesar dos possíveis benefícios desse cálculo, como um “desejável” prolongamento da vida, se esse mesmo indivíduo não começar e/ou não conseguir agir de acordo com o que dele se espera sendo um "pré-paciente", isso talvez enseje, em alguns casos, a opinião de que é um fraco, um destituído de vivacidade moral. Nessa direção, a suscetibilidade contemporânea, apoiada na ideia de risco, transforma-se em uma ferramenta sutil: ela dita, com base na concepção de uma individualidade somática, o que é ou não moral, promovendo, assim, subjetivações individuais e coletivas.

Abrindo um parêntese, é interessante observar que a personalidade somática contemporânea encontra na imagem social do corpo, além de um suporte identitário, o fundamento da própria moral. Assim, de acordo com Costa (2004), a contrapartida desviante da personalidade somática de nosso tempo é a estultícia. Os estultos de hoje são "os que ficam para trás na maratona da fitness; obesos; manchados de pele; sedentários; envelhecidos precocemente; tabagistas; não siliconados; não lipoaspirados; etc.” (COSTA, 2004, p. 196). Podendo nessa lista ser acrescentados também, é claro, os que não se submetem a um governo da vida com base em cálculos e prognósticos de risco. Dessa forma, no campo das suscetibilidades, "podem-se observar novas formas de subjetivação assumindo vulto, novas autotecnologias cuja 'substância ética', para usar a expressão de Foucault, é o soma, e cujo fim é o prolongamento da vida sadia” (ROSE, 2013, p. 140).

Quanto ao aprimoramento, devemos notar que ele não é uma meta exclusivamente atual. Em muitos momentos da história os seres humanos desenvolveram métodos buscando melhorar os seus si mesmos corporais. Fizeram isso por meio de oração, meditação, dieta, exercícios físicos, espirituais etc. Nem a vontade de se aprimorar nem o aprimoramento em si mesmo, tal como é apontado por Rose (2013), devem ser considerados novidades. Porém, comparado com o que já foi feito no passado, a "normalização", que era o principal motivo de preocupação dos indivíduos que se apoiavam nesses métodos, foi deslocada para a busca de "adequação" (ROSE, 2013). Em outros termos, se anteriormente as intervenções corporais eram feitas com o objetivo de curar patologias, normalizar a saúde, ou "promover estratégias biopolíticas através da modificação do estilo de vida", hoje as pessoas que buscam o aprimoramento "são consumidores, tendo acesso a escolhas com base em desejos que podem 
parecer triviais, narcisísticos ou irracionais, modelados não por necessidade médica, mas pela cultura de mercado e de consumo" (ROSE, 2013, p. 37). Isso pode ser corroborado, por exemplo, observando o fenômeno dos "pacientes e médicos-celebridades" que protagonizam, obedecendo aos interesses da indústria da moda, aos padrões corporais que devem ser seguidos, e oferecem visibilidade social às tecnologias de otimização.

Os "efeitos estéticos" de implantes hormonais foram destacados nos principais títulos da impressa. A cobertura do São Paulo Fashion Week 2012, por exemplo, apresentou implantes hormonais como "chipes da beleza" usados por modelos para suprimir a menstruação, diminuir a celulite e evitar o ganho de peso. O único problema do "chipe hormonal", segundo a modelo Natália Zambiasi, é que "você fica tarada por sexo". A ex-namorada do jogador de futebol Ronaldo, a modelo Raica Oliveira, explicou que usou o implante por oito anos com objetivos estéticos: "[Sem ele] preciso fazer mais ginástica, meu bumbum fica flácido; quando uso o implante, ele fica firme e sarado". Outra modelo comentou: "Você 'seca', desincha, perde peso, elimina a celulite, adquire músculos, seu corpo fica mais firme e a textura da pele melhora. E, de quebra, você se livra da menstruação!" Ginecologistas de celebridades, como Montgomery e Elsimar Coutinho, promovem seus trabalhos por meio de "parcerias" com a indústria da moda. (EDMONDS; SANÁBRIA, 2016, p. 202).

Vemos, desse modo, que o que está sendo proposto por meio dessas tecnologias é um estado de maior satisfação pessoal e/ou maior felicidade, e com o mínimo de esforço. Isso pode parecer ainda estranho, mas há uma promessa muito bem acolhida de que as pessoas podem ser "mais" bonitas simplesmente implantando um "chip da beleza", desejar ser magra mesmo comendo e/ou até mesmo viris, apesar da velhice. Nesse cenário, é fácil pensar em situações $^{77}$ nas quais podemos remodelar à vontade os humores, emoções, desejos, incrementar a memória, inteligência e atenção simplesmente tomando uma pílula e/ou investindo no treinamento do cérebro.

Porém, vale a pena ressaltar que alguns pensadores, como o próprio Rose (2013), mostram-se céticos em relação ao uso isolado dos fármacos na remodelação dos humores e das emoções, pois, para ele, é difícil que isso aconteça apenas pela ingestão de uma pílula. A mudança nos humores dependeria também de um ulterior trabalho sobre o si mesmo. $\mathrm{O}$ mesmo volume de álcool, por exemplo - que também promove um fator de mudança no humor -, tem consequências comportamentais e emocionais bem diferentes, e isso vai “[...]

\footnotetext{
77 Existe, principalmente na internet, debates e propagandas de produtos farmacológicos que prometem remodelar as emoções e aumentar os resultados cognitivos. Disponível em: http://fd7.com.br/a-melhor-pilula-dainteligencia/; http://bombanarede.blogspot.com.br/2015/10/sem-limites-pilula-capaz-de-turbinar-o.html. Acessos em: 5 mar. 2018.
} 
depender de se é ingerido em uma noite solitária e melancólica, em casa, em uma festa de celebração do quadragésimo aniversário, na esplanada de um jogo de futebol ou no contexto controlado de uma experiência psicológica” (ROSE, 2013, p. 147).

No entanto, a questão é diferente quando não estão em jogo o humor ou a emoção, mas a cognição. Parece que já estamos começando a ver o uso difuso de fármacos para aumentar as funções mentais: "Os exemplos principais são o frequente uso de Ritalina ${ }^{78}$ entre estudantes que não foram diagnosticados com TDAH; o uso de Provigil (modafinil), do Cephalon, desenvolvido para o tratamento de distúrbio do sono, é uma tentativa de aumentar o estado de alerta e a energia mental" (ROSE, 2013, p. 149). Como nota Preciado (2018), se na sociedade disciplinar as tecnologias de subjetivação controlavam o corpo a partir do exterior como um aparato ortoarquitetônico, agora essas tecnologias passam a fazer parte do corpo “diluem-se nele, tornando-se somatotécnicas" (PRECIADO, 2018, p. 85).

Da mesma forma, porém, que há uma preocupação com as implicações éticas do uso de tecnologias de aprimoramento no aumento do desempenho esportivo, isso também parece suceder no âmbito do aprimoramento cognitivo, principalmente com o uso de fármacos. Afinal, como a escola, os pais, os educadores e os próprios estudantes deveriam posicionar-se diante de indivíduos que, sem nenhuma patologia, usam medicamentos para melhorar suas performances no âmbito da aprendizagem escolar? Um dos efeitos dessa preocupação, segundo Rose (2013), é o surgimento de um novo ramo da ética, a neuroética, que vem oferecendo ocasião para a compreensão da política contemporânea da vida. Mas, quando a ética se torna neuronal, “[...] implica que nossas tecnologias da subjetividade também se tornaram neuronais; ou seja, parece que em alguns pontos, nós nos tornamos 'si-mesmos neuroquímicos"” (ROSE, 2013, p. 40).

A molecularização da vida e as tecnologias de otimização vêm contribuindo, segundo Rose (2013, p. 46), para o surgimento de novas formas de subjetivação, caracterizando o terceiro elemento da biopolítica contemporânea, a etopolítica, que, resumidamente, corresponde a "tentativas de modelar a conduta dos seres humanos mediante influência em seus sentimentos, crenças e valores - [...], agindo sobre a ética”. Trata-se de uma política de como deveríamos conduzir a nós mesmos apropriadamente em relação a nós mesmos e com vistas ao futuro, ou seja, uma espécie de autoengendramento de um éthos ligado às novas

\footnotetext{
${ }^{78}$ A Ritalina é um psicoestimulante prescrito majoritariamente no tratamento de crianças diagnosticadas com TDAH. Se consumida em certa dosagem, defende-se que auxiliaria no desempenho de tarefas escolares e acadêmicas, pois aumenta a capacidade das funções executivas, potencializando a concentração, além de atuar como atenuador da fadiga (ITABORAHY, 2009).
} 
tecnologias da vida, ou tecnologias do self: "Se a 'disciplina' individualiza e normaliza, e a 'biopolítica' coletiviza e socializa, a 'etopolítica', ela própria, diz respeito às autotécnicas pelas quais os seres humanos deveriam julgar a si mesmos e intervir em si mesmos para se tornarem melhores do que são" (ROSE, 2013, p. 46).

Entre as preocupações da etopolítica, estariam temas como "qualidade de vida", "direito à vida", ou "direito de escolher", "eutanásia", "terapia genética", "clonagem humana" etc. (ROSE, 2013). Assim, por um lado, a etopolítica rompe com a ideia de uma natureza original e com conceitos essencialistas da existência humana; por outro, a sua particularidade encontra-se na possibilidade de construção e até mesmo de uma reconstrução vital.

Ao ser contrastado com a racionalidade neoliberal, a etopolítica, no entanto, acaba por ligar-se ao éthos da existência apenas na medida em que podemos ser "empresários de nós mesmos", isto é, enquanto fazemos parte de certa lógica econômica na qual ser "melhor" ou optar pela maximização da própria vitalidade significa também ser mais eficiente e produtivo. De qualquer maneira, a etopolítica é a responsável por criar o ambiente dentro do qual as novas formas de autoridade ou expertise assumem espaço, o que caracteriza o quarto elemento da biopolítica contemporânea, o seu poder pastoral.

Entre as novas autoridades que protagonizam as práticas atuais do biopoder, ou seja, a expertise, Rose (2013, p. 47) assinala o aparecimento de um tipo específico: "os peritos da vida em si mesma". Tais personagens atuam como cuidadores, terapeutas e conselheiros apresentando opções cujas escolhas recaem sob a responsabilidade dos indivíduos, os quais assumem a tarefa de aprimorar seu próprio corpo. Trata-se, por exemplo, de conselhos relacionados à propensão a vícios, saúde mental, saúde sexual, educação escolar, fertilidade, planejamento familiar, reprodução etc. São uma espécie de gurus modernos, mas, em vez de consultar uma "consciência cósmica" e, enigmaticamente, predizer o futuro, fazem cálculos somáticos verificando informações genéticas, hormonais e neurais: "Desde peritos em célulastronco até gerontologistas moleculares, de neurocientistas a tecnologistas da clonagem, surgiram novos especialistas do corpo, cada um com seu próprio aparato de associações, encontros, periódicos, linguagens esotéricas, atores-estrelas e mitos" (ROSE, 2013, p. 49).

O que tem chamado atenção nos poderes pastorais é a orientação que fazem em relação ao futuro, uma espécie de cálculo científico premonitório. Nessa direção, o neurologista britânico Adrian Raine ${ }^{79}$ (2015) tem pesquisado fatores neurológicos, com

\footnotetext{
${ }^{79}$ Em 2015, Adrian lançou o livro A anatomia da violência: as raízes biológicas da criminalidade, apresentando um conjunto de evidências que mostra como a genética pode contribuir para gerar um cérebro criminoso. Essas e outras pesquisas, claramente, demonstram uma herança lombrosiana.
} 
origens genéticas ou ambientais, relacionados com o comportamento violento. Fundamentando-se em estudos genéticos, tecnologias de imageamento cerebral, neuroquímica, psicofisiologia e neurocognição, Raine “[...] acredita que um dia será possível prever quem tem maiores chances de cometer um crime apenas por meio de imagens de seu cérebro" (MENDES; IBRAIM, 2017, p. 117). Seguindo essa mesma lógica:

\begin{abstract}
Alguns estão propondo teste de suscetibilidade no sistema de serotonina ligado à inabilidade de controlar a conduta - ou seja, em crianças indisciplinadas em idade escolar ou naqueles condenados por crimes agressivos ou impulsivos. Aqui, no campo neurocientífico e psicofarmacológico, as respostas que pretendem ser tratamento já estão ao alcance da mão sob a forma de administração preventiva de remédios psiquiátricos. (ROSE, 2013, p. 140).
\end{abstract}

Supondo então que as tecnologias de imageamento do cérebro sejam aperfeiçoadas ainda mais e que uma triagem preventiva possa ser realizada, possibilitando dizer quais são os indivíduos potencialmente perigosos e que apresentam risco de cometer crime violento: Quais seriam as implicações? ${ }^{80}$ Onde iria parar a presunção de inocência tão defendida pelo sistema judicial? Ou, ainda, a pessoa considerada culpada de algum crime ou ato violento teria o direito de alegar responsabilidade menor por motivos médicos? Mas deixando de lado essas questões, uma vez que que Deleuze (1992, p. 4) já apontara para a possível realidade de um sistema de controle que pudesse monitorar os indivíduos em todos os lugares e situações “[...] animal numa reserva, homens numa empresa (coleira eletrônica) ", compreendemos que o que está sendo anunciado é uma espécie de controle intermolecular e/ou uma expansão do poder sobre a sutileza do corpo, "No regime dos hospitais: a nova medicina 'sem médico nem doente', que resgata doentes potenciais e sujeitos a risco, o que de modo algum demonstra um progresso em direção a individuação, como se diz, mas substitui o corpo individual ou numérico pela cifra de uma matéria 'dividual' a ser controlada” (DELEUZE, 1992, p. 4).

Em meio a expectativas que parecem aproximar-se da ficção científica, e até da realidade mesma, novos potenciais de gerenciamento da vida estariam emergindo, mas não se trata aqui de um tipo de pastoreio em que o pastor é o único responsável pela condução de seu rebanho, "Implica uma dinâmica séria de relações entre os bens pessoais daqueles que aconselham e os dos que são aconselhados" (ROSE, 2013, p. 48). Além disso, esses conselhos são realizados mediante a utilização de tecnologias modernas, como as das ciências

\footnotetext{
${ }^{80}$ Steven Rose (2006), por exemplo, mostra que no Reino Unido o antigo secretário do Interior, David Blunkett, já acreditava ser possível ter o direito de tomar medidas preventivas com base em anormalidades detectadas em regiões específicas do cérebro, como no córtex pré-frontal, ou na estrutura e atividade da amígdala cerebral.
} 
genômicas e neurais que obscurecem as fronteiras da coerção e do consentimento e são capazes, elas mesmas, de transformar e conduzir as subjetividades daqueles que são aconselhados.

Por fim, associado a esses quatro primeiros elementos, Rose (2013) detecta um quinto: a capitalização da nossa própria vitalidade e/ou o aparecimento de uma bioeconomia. Esse último elemento diz respeito ao surgimento de circuitos bioeconômicos de troca fundamentados na captura do valor latente dos processos biológicos, no aprimoramento da saúde e no crescimento econômico. Os novos conhecimentos moleculares da vida e da saúde estariam sendo mapeados, desenvolvidos e explorados por uma variedade de empresas comerciais, algumas vezes em aliança com Estados, outras vezes de forma autônoma a estes, estabelecendo conexões constitutivas entre vida, verdade e valor. Trata-se, por exemplo, do aparecimento e da exploração de circuitos de "biovalores", isto é, modos pelos quais o corpo e os tecidos humanos estariam sendo recolhidos para manipulação, preservação e incremento da própria vitalidade. Fala-se aqui em células-tronco, populações genéticas singulares, linhagem de células, reagentes, sequências de DNA etc.

O que chama atenção na bioeconomia é que, além de mercantilizar a relação de cada um com seu próprio corpo, produzindo um biocapital, ela estaria acionando também mecanismos próprios do funcionamento econômico atual no intuito de sofisticar as relações de consumidor que cada indivíduo tem com as autoridades somáticas. Uma das consequências mais visíveis disso seria um aumento nos lucros das empresas de biotecnologia: "Em 2003, Ernst e Yang relataram que o setor biotecnológico dos Estados Unidos era uma indústria de US\$ 33,6 bilhões, com um total de 1.446 companhias, 318 das quais são públicas” (ROSE, 2013, p. 59). Em certo sentido, a economia estaria caminhando em direção a uma valoração, ou um cálculo financeiro da própria vida, e os seus circuitos seriam conceituais, comerciais, éticos e espaciais: "abrangem o atômico, o celular, o orgânico, os espaços de práticas (laboratórios, clínicas, consultórios, fábricas), as cidades e suas economias” (ROSE, 2013, p. 62).

Paralelo a esse tipo de capitalização da vitalidade, percebemos que as companhias farmacêuticas também vêm demonstrando interesse pela lógica bioeconômica. Winograd (2010) relata que, entre 2001 e 2005, a prescrição de psicofármacos nos Estados Unidos teria aumentado em torno de 75\%, e, no Brasil, estimava-se, em 2011, que cerca de 2,5 milhões de crianças estariam tomando antidepressivos. Ainda, segundo a autora, entre 2002 e 2006, assustadoramente, a produção brasileira de Ritalina - droga prescrita para o TDAH - teria 
crescido $465 \%$. Tudo isso corroborando o crescimento de um ramo da economia que também teria como finalidade atuar sobre aspectos da vitalidade humana, mas agora associando moléculas, células, química e neuroquímica a humores, atenção, cognição etc.

Reforçando ainda mais essas informações, e de certa maneira criando um ambiente de suspeita sobre isso que também parece ser uma economia dos estados mentais, uma espécie de nooeconomia ${ }^{81}$ - para fazer um paralelo com bioeconomia -, a jornalista e escritora Eliane Brum (2013), ao comentar sobre a edição do Manual Diagnóstico e Estatístico de Transtornos Mentais (DSM-5), diz em artigo publicado na revista Época que muitas pessoas, mesmo as que se consideram normais, poderiam facilmente vir a fazer parte da nova lista de diagnósticos: "Não estou sozinha. Está cada vez mais difícil não se encaixar em uma ou várias doenças" (BRUM, 2013). Para justificar essa conclusão, a jornalista mostra que com a nova lista de classificação das patologias mentais, que inclui mais de 350 tipos, a psiquiatria teria conseguido a proeza de transformar a normalidade em anormalidade. O curioso disso, e o motivo de suspeita, é que para cada nova patologia anunciada, ou para cada nova classificação, estaria sendo aberto um novo mercado para a indústria farmacêutica. Assim, o DSM-5 estaria tipificando, por exemplo, a "birra infantil" como Transtorno Disruptivo de Desregulação do Humor, tratável por meio de medicamentos; o luto, se a tristeza persistir por mais de duas semanas, passaria a ser tratado como depressão; e a Tensão Pré-Menstrual, em alguns casos, teria se transformado em um Transtorno Disfórico.

Uma reportagem do The New York Times sobre o tema conta que o psiquiatra Ned Hallowell, autor de best-sellers sobre TDAH, hoje arrependese de dizer aos pais que medicamentos como Adderall e outros eram "mais seguros que Aspirina". Hallowell, agora mais comedido, afirma: "Arrependo-me da analogia e não direi isso novamente". E acrescenta: "Agora é o momento de chamar a atenção para os perigos que podem estar associados a diagnósticos displicentes. Nós temos crianças lá fora usando essas drogas como anabolizantes mentais - isso é perigoso e eu odeio pensar que desempenhei um papel na criação desse problema". No DSM-5, a idade limite para o aparecimento dos primeiros sintomas de TDAH foi esticada dos 7 anos, determinados na versão anterior, para 12 anos, aumentando o temor de uma "hiperinflação de diagnósticos". (Brum, 2013).

Esses novos elementos da biopolítica são compreendidos por Rose (2013, p. 120)

\footnotetext{
${ }^{81}$ Nô̂s, em grego significa mente, intelecto, espírito. Está claro, no entanto, que a mente aqui não se refere a uma entidade ou substância distinta do corpo, como em grande parte da tradição em filosofia, mas a uma espécie de epifenômeno cerebral. Sugerimos, desse modo, o termo nooeconomia para designar uma nova racionalidade econômica voltada para a capitalização dos estados mentais, seja por meio do uso de fármacos, ou, como veremos, pelos empreendimentos dos neuronegócios (academias de ginástica cerebral, literatura de autoajuda cerebral etc.).
} 
como fazendo parte de sendas contingentes de "uma forma de vida emergente". Os saberes moleculares da vida, as tecnologias de otimização, os processos de subjetivação, as novas autoridades somáticas e a economia da vitalidade estariam suscitando um emaranhado de opiniões, esperanças, interesses, valores, aspirações, poderes, mas também novas formas de conhecer e de ser no mundo, "mais do que apenas uma maneira de viver, a ideia de uma forma de vida também se refere à forma de vida, às entidades que povoam aquele jeito de viver e suas características" (ROSE, 2013, p. 121). Assim, estaríamos nos movendo de uma política que desde o século XVII atuava sobre o corpo dos indivíduos e da população potencializando-o, tornando-o mais dócil e mais produtivo, para outra que agora é capaz de alterar a vida de cima a baixo, ou vice-versa, atuando na interioridade e na exterioridade dos corpos, corrigindo-os, aprimorando-os, produzindo novos parâmetros de normalidade e também os governando, mas agora começando desde as informações genéticas, dos neurônios, por meio da química e da neuroquímica.

\begin{abstract}
Nas tecnologias de reprodução venceram limitações naturais da idade, infertilidade, da sexualidade na procriação. $\mathrm{O}$ teste genético in utero permite optar contra certas doença e incapacidades hereditárias. [...] Psicofármacos, ainda que não sejam tão eficazes e previsíveis quanto muitos dão a entender, realmente permitem alguma modificação no humor, na emoção, na cognição e na volição. Algumas das normatividades antigamente consideradas como inscritas nas leis da vida orgânica já se moveram, pelo menos no rico ocidente, para o campo da escolha, e estão carregadas com todas as exigências que a escolha impõe. Tornou-se possível às pessoas pensar seus si-mesmos corporificados como abertos à modificação em novas formas e, portanto, a adquirir ulteriores obrigações para o autogerenciamento responsável de sua existência biológica somática. (ROSE, 2013, p. 122).
\end{abstract}

\title{
2.3.1. O self neuroquímico
}

A afirmação de que estamos vivendo "uma forma de vida emergente" (ROSE, 2013, p. 120) nos remete a uma situação em que determinado modo de ser no mundo estaria sendo produzido, e a maneira com que pensamos e agimos sobre esse modo de ser determinaria outras formas de convívio, criando, por exemplo, novas maneiras de educar, aprender, trabalhar, cuidar da saúde, produzir valores, governar etc. Não se trata aqui de dizer especificamente que vida é essa ou apontar para a sua forma encarnada de ser, talvez nem seja o caso de falar em uma única forma de vida, mas de formas, e entender os modos de sociabilidade que estão derivando e podem derivar desse acontecimento. Fala-se, assim, em clonagem terapêutica, manipulação genética, cirurgias estéticas, modificações 
comportamentais com uso de remédios, alteração da memória, melhoramento do humor, aumento da inteligência etc. No registro do que nos propomos a estudar, uma das expressões dessa forma emergente de vida parece ser o próprio sujeito cerebral. O cérebro vem emergindo como o órgão da identidade do ser, tornou-se o fundamento de muitas das práticas sociais, econômicas e políticas.

No entanto, cabe aqui um breve esclarecimento, especialmente no que se refere à ideia de emergência. Tradicionalmente, quando se fala em emergência, o que se coloca é certa interpretação não reducionista dos fenômenos que estão sendo estudados. A emergência designa um “[...] estado de coisas no qual as propriedades de um certo domínio não se reduzem completamente às propriedades de outro domínico (seriam 'autônomos'), apesar de serem, em algum sentido, produzidos por este outro domínico (ou serem 'dependentes' deste)" (PESSOA, 2013, p. 22). A questão é que, ao falar sobre uma subjetividade cerebral, torna-se óbvio uma interpretação reducionista de identidade, estamos afirmando que "somos o nosso cérebro", isto é, que todas as funções superiores, como pensar, escolher, memorizar, sentir, imaginar, aprender, entre outras, podem ser reduzidas a relações neuronais.

Então, diante disso, qualquer pessoa poderia facilmente ser movida a admitir uma contradição: como dizer que o sujeito cerebral é uma forma "emergente" de vida, sendo que ele é a expressão reducionista de uma interpretação de nós mesmos? Para desfazer essa contradição, devemos notar que a palavra "emergência" não se refere apenas à relação do cérebro com a identidade, embora ela seja admitida também, mas a todo um conjunto de forças ou práticas, tais como médicas, legais, econômicas, políticas, éticas, tecnológicas, educacionais, midiáticas etc., que faz com que nossa subjetividade e personalidade sejam reduzidas ao cérebro. Diz respeito aos efeitos de verdade produzidos por uma interpretação biologizada de nós mesmos e, é claro, à maneira com que o poder também atua sobre a vida. Trata-se, enfim, de uma forma contemporânea de subjetivação. Para demarcar melhor o assunto, talvez seja o caso de admitirmos, assim como o fez Foucault (2015), que recorrer à emergência não significa apontar uma potência antecipadora de sentido, mas um jogo casual entre diferentes domínios, que a emergência é a entrada em cena de forças, "[...] é sua interrupção, o salto pelo qual elas passam dos bastidores para o teatro, cada uma com seu vigor e sua juventude" (FOUCAULT, 2015, p. 67).

Assim, voltando-nos para as novas formas de sociabilidade produzidas pela emergência do sujeito cerebral, uma situação que exemplifica muito bem aquilo que queremos destacar é apresentada por Ortega (2009b), quando comenta a respeito das transformações no 
âmbito do tratamento do alcoolismo. Se até o fim do século XX as pessoas acreditavam, orientadas pelos conhecimentos psi, que o abandono do vício dependia de uma mudança no interior do próprio viciado, uma vez que o alcoolismo era tido como uma fraqueza moral e da vontade, hoje as descrições neurocientíficas do alcoolismo, ao detalhá-lo como uma disfunção neuroquímica, fazem com que as tradicionais práticas confessionais da Associação dos Alcóolicos Anônimos (AAA) sejam substituídas pela decisão do dependente em tomar uma pílula.

Outro exemplo, é a redução à ordem cerebral de fatores humanos como a desatenção e a indisciplina. Consta na história da medicina que em 1902 um pediatra chamado George Still, em publicação na revista Lancet, descreveu uma criança como "agitada, desviante, malévola e carente de vontade inibidora" (ROSE, 2006, p. 278). Algum tempo depois, em 1968, essa descrição teria servido de fundamento e inspiração para o diagnóstico de "reação hiperativa", atualmente conhecido como TDAH. Passados mais de cem anos entre a primeira descrição e os diagnósticos atuais de transtorno, a compreensão da causa desses comportamentos - considerados desviantes - modificou-se consideravelmente, e com ela os próprios modos de intervenção. Se as bases das "aberrações" desviantes, inicialmente, foram relacionadas a causas ambientais e sociais, ou a uma sociabilidade defeituosa, atualmente elas passaram a ser localizadas dentro da cabeça da criança, e o seu tratamento é proposto em termos de intervenção cerebral. Há, desse modo, uma clara preocupação, expressa nos novos saberes, em fazer uma política da vitalidade intervindo e controlando comportamentos que até então eram tidos como incontroláveis.

De outro modo, muitas daquelas respostas que antes eram oferecidas pelas ditas ciências humanas - sociologia, psicologia, antropologia, pedagogia etc. - para vários dos problemas sociais, agora estão se deslocando para o campo especializado do conhecimento do cérebro.

Uma vez classificados como doentes, as pessoas tornam-se pacientes e
consequentemente consumidoras de tratamentos, terapias e medicamentos,
que transformam o próprio corpo e a mente em origem dos problemas que,
na lógica patologizante, deveriam ser sanados individualmente. As pessoas é
que teriam problemas, seriam disfuncionais pois não se adaptam, seriam
doentes pois não aprendem, teriam transtornos pois são indisciplinadas.
(COLLARES; MOYSÉS, 2013, p. 17).

Assim, o mau comportamento, o desvio moral, a inabilidade social e outras condutas consideradas prejudiciais ao convívio humano são largamente tratados como coisas do 
cérebro e vistos na individualidade. A composição desse "si mesmo" cerebral, ou a substituição dos fatores sociais pelos neurais, principalmente no universo das práxis, como indicado em Ehrenberg (2009) e Rose (2013), vem sendo produzida por trabalhos em neurociências e psiquiatria, que desde a segunda metade do século XX mapeiam e consideram as bases neurais e neuroquímicas da vida mental.

Enquanto na primeira metade do século XX era comum distinguir entre doenças funcionais - não relacionadas a uma patologia cerebral - e orgânicas, agora essa divisão não parece mais fazer sentido, "a mente é simplesmente o que o cérebro faz" (ROSE, 2013, p. 268). Isso mostra que a herança cartesiana, e mais atualmente os conhecimentos $p s i$, não sem uma dose de tensão, vem perdendo espaço, e a verdade sobre nós mesmos começa a ser narrada por pesquisas neurológicas e testes laboratoriais.

Há cérebros mesmos. Esses cérebros psiquiátricos são imaginados como "órgãos" como outros órgãos do corpo - com suas regiões e seus constituintes: o córtex pré-frontal, o gânglio basal, o lobo temporal, o sistema límbico, os neurônios no córtex cingulado - e também alguns sistemas corporais associados, tais como o fluído cérebro-espinal (CSF), ou sistemas dos quais se pensa que se comportam de maneira análoga ao cérebro, tais como as plaquetas sanguíneas. Há cérebros químicos: 3,5 de adenosina monofostato cíclica, monoamino-oxidase, acetilcolina, GABA, glicina catecolaminas (noradrenalina e dopamina), serotonina e seus precursores e produtos de degradação, peptídeos (incluindo-se endorfinas, angiotensina e os fatores desencadeadores), juntamente com seus vários precursores e produtos de degradação. (ROSE, 2013, p. 266, grifo nosso).

Uma vez que "há cérebros mesmos" e que as neurociências e a psiquiatria acreditam que eles são causalmente responsáveis por tudo aquilo que se relaciona com a identidade, descrevê-los tornou-se sinônimo de mapeamento não apenas molar, mas molecular, químico e neuroquímico. Então, desde os anos de 1960, como nos mostra Andreasen (2003), intensificaram-se os empreendimentos para descobrir as possíveis bases neuroquímicas de nossos "selves", as quais, pouco a pouco, vêm sendo descritas em componentes específicos, tais como: canais de íon, vesículas sinápticas, regulação de receptor, isolamento de receptor, ligação de receptor, metabolismo de monoaminas, dopamina, norepinefrina, epinefrina, acetilcolina, serotonina, glicose etc. (ROSE, 2013). De outro modo, a experiência vivida, ou a subjetividade, começa a ser compreendia por uma linguagem somática e cerebralista, sendo que os caracteres neuroquímicos se tornam o principal alfabeto para representá-la convertem-se em elementos-chave na interpretação de nós mesmos. 
A partir dessas transformações, condutas, sentimentos, escolhas, capacidades e aptidões começam a ser analisadas e reduzidas a uma perspectiva cerebralista, desconfortavelmente sinalizando uma mudança nos conceitos de responsabilidade e liberdade humanas. Assim, especula-se sobre a neuroquímica da depressão, os transtornos cerebrais responsáveis pelo comportamento criminoso, os efeitos da fé sobre o cérebro, o cérebro indisciplinado, hiperativo, criativo, entre outros. Nessa direção, o tratamento das disfunções mentais tende a ser realizado, majoritariamente, por meio do uso de componentes químicos produzidos para afetar ou imitar elementos do próprio cérebro, tal como os vários tipos de antidepressivos usados pela psiquiatria contemporânea ${ }^{82}$. Em contrapartida, havendo o desejo ou a necessidade de se adequar às normas da boa performance cognitiva, o cérebro é que também será enfatizado.

O curioso nisso tudo é que os avanços da psiquiatria vão sendo atrelados à fabricação dos produtos psicofarmacológicos, as companhias produtoras convertem-se em "laboratórios centrais para a inovação psiquiátrica" (ROSE, 2013, p. 306), resultando daí, além da transformação na forma de pensar e agir a respeito das desordens do pensamento - fazendo com que aquilo que era considerado social viesse a ser neural -, uma acomodação dos padrões do pensamento psiquiátrico aos ditames das empresas farmacológicas.

Exemplo disso, aqui mostrado anteriormente, seria o processo de patologização de comportamentos e de sentimentos até então tidos como naturais, ou de ordem social, tais como birra infantil, luto, tristeza etc., transformando-os em disfunções cerebrais. Afinal, como pontua Eliane Brum (2013), quem são essas pessoas que acham que o "normal" é superar a perda de uma mãe, de um pai, de um filho, de uma companheira em um tempo matematicamente cronometrado? "Que tipo de ser humano consegue essa proeza? Quem seríamos nós se precisássemos de apenas duas semanas para elaborar a dor por algo dessa magnitude? Talvez o DSM-5 diga mais dos psiquiatras que a organizaram do que dos pacientes" (BRUM, 2013).

O resultado desse reducionismo neural, da medicalização da vida e do crescimento da indústria farmacêutica seria uma espécie de (in)formação neuroquímica da própria pessoa, ou o surgimento daquilo que Rose (2013) chama de "self-neuroquímico". Trata-se da produção de uma nova forma de subjetividade na qual os estados de humor e os processos cognitivos

\footnotetext{
82 "Para aqueles que estão se tornando si-mesmos neuroquímicos, tais remédios prometem ajudar o próprio indivíduo, em aliança com o médico e com a molécula, a descobrir a intervenção que tratará precisamente de uma anomalia molecular específica, na raiz de algo que perturba pessoalmente o indivíduo em questão e altera sua vida, a fim de restaurar-lhe o si-mesmo a sua vida, a si mesmo" (ROSE, 2013, p. 293).
} 
são definidos em categorias médicas e relações entre taxas de transmissões de serotonina e dopamina no cérebro, por exemplo.

O interessante é que a construção dessa subjetividade, diferentemente do que acontecia até o fim do século XIX, não tem como pano de fundo a figura do Estado, mas está relacionada aos desenvolvimentos biotecnológicos e ao fortalecimento de empresas privadas, como é o caso dos laboratórios e das companhias farmacêuticas. E, na mesma linha do sujeito cerebral, o self- neuroquímico torna-se uma expressão emergente de uma forma de vida capaz de criar outras maneiras de convívio: "indivíduos e suas autoridades - clínicos gerais, enfermeiros, professores, pais - estão começando a recodificar as variações nos humores, nas emoções, nos desejos e nos pensamentos em termos de funcionamento do cérebro químico deles, e a interferir neles mesmos à luz dessa crença" (ROSE, 2013, p. 309).

Assim, tanto o sujeito cerebral quanto o self-neuroquímico constituem novos modos de subjetivação, mas o primeiro mostra-se mais abrangente, "implica reconhecer outras tecnologias de aprimoramento de si que não são restritas ao uso de psicofármacos, mas podem envolver, por exemplo, exercícios para o cérebro, técnicas de memorização e técnicas de neuroascese" (SILVA; VAZ, 2016, p. 218). Se a noção de self-neuroquímico faz crescer um consenso em torno da ideia de que as disfunções mentais são causadas por desequilíbrios de componentes químicos no cérebro - sendo possível tratamento por meio da utilização de drogas -, além de se poder recorrer a produtos de toda ordem para uma eventual maximização do próprio cérebro, a ideia de um sujeito cerebral, por sua vez, acaba por abrir uma espécie de espaço não especializado para a manipulação desse órgão, tendo em vista, por exemplo, a grande quantidade de pessoas que, mesmo nunca tendo estudado empiricamente o interior de uma estrutura encefálica, acredita poder investir em seu aprimoramento, oferecendo conselhos, escrevendo livros de autoajuda cerebral, dando consultorias, elaborando academias de ginástica cerebral e creditando-se a autoridade de dizer algo que importa no âmbito da aprendizagem.

Podemos concluir, então, que o que está sendo anunciado não é simplesmente uma mudança nas estratégias epistemológicas de apreensão dos selves, mas uma transformação na ontologia humana - nos tipos de pessoas que consideramos ser e no que pensamos poder nos tornar. Trata-se de um novo jeito de pensar e atuar sobre a própria identidade e, ainda, diz respeito a novas estratégias de governo da vida "procurando agir sobre, por meio do cérebro governar pelo cérebro" (ROSE, 2010, p. 311), mas que também abre espaço a formas de desobedecer e resistir. 


\section{CAPÍTULO 3}

\section{A POLÍTICA DO DESEMPENHO E A AMPLIAÇÃO DOS BONS EQUIPAMENTOS}

\subsection{APRIMORAMENTO COGNITIVO E PRODUÇÃO DE CAPITAL HUMANO}

Como vimos em Rose (2013), o cenário em que nos encontramos, o qual teve início nas últimas décadas do século passado, mostra um deslocamento da responsabilidade da saúde do indivíduo e da coletividade, que antes era do Estado, para um processo de autogestão. Se o poder sobre a vida, tal como nos aponta Foucault (2014), desde a modernidade foi exercido por tecnologias disciplinares que enfatizavam o corpo e por técnicas de regulação da população - com uma panóplia de estratégias governamentais concentradas no saber, no controle e no bem-estar, visando ao gerenciamento dos processos vitais -, hoje esse poder parece estar sendo rearticulado "naquilo que se poderia chamar de uma racionalidade pósdisciplinar" (RABINOW, 1999, p. 135). Em outros termos, novos discursos e práticas de biopoder estão emergindo. $\mathrm{O}$ corpo e a população, paralelamente, começam a ser rearticulados. Exemplo disso são os signos indicativos derivados do Projeto Genoma ${ }^{83}$ e das neurociências, por meio dos quais é possível perceber um novo horizonte de sociabilidade, autoprodução, além de novas formas de governo da vida.

No futuro, a nova genética deixará de ser uma metáfora biológica para a sociedade moderna e se tornará uma rede de circulação de termos de identidade e lugares de restrição, em torno da qual e através da qual surgirá um tipo verdadeiramente novo de autoprodução: vamos chamá-lo de biossociabilidade. Se a sociologia é a cultura construída com base numa metáfora da natureza, então, na biossociabilidade a natureza será modelada na cultura compreendida como prática; ela será conhecida e refeita através da técnica, a natureza finalmente se tornará artificial, exatamente como a cultura se tornou natural. (RABINOW, 1999, p. 143-144).

Os sinais dessa nova racionalidade, a despeito das expectativas, também são corroborados pelas análises de pesquisadores que se popularizam nas prateleiras de livrarias, como Byung-Chul Han (2017, p. 24), principalmente quando este observa que hospitais,

\footnotetext{
${ }^{83} \mathrm{O}$ genoma - composto da totalidade do material genético - traz codificado no DNA dos cromossomos as instruções que irão afetar não apenas a estrutura, o tamanho, cor e outros atributos físicos dos indivíduos, como também a inteligência, a suscetibilidade a doenças, o tempo de vida e até alguns aspectos do comportamento. $\mathrm{O}$ nosso padrão genético contém aproximadamente três bilhões de pares de bases químicas. A meta do Projeto Genoma, então, é decifrar o código genético e compreender os milhares de genes que compõem o DNA humano, entender, por exemplo, os mecanismos de doença para que se possam aplicar tecnologias para alterar certas instruções com vistas a produzir uma melhoria e/ou otimização na qualidade de vida do organismo.
} 
asilos, presídios, quartéis e fábricas, que então constituíam os espaços disciplinares estudados por Foucault, e também certa "negatividade da proibição" ${ }^{84}$ foram recobertos por uma sociedade na qual os espaços que se sobressaem são as "academias de fitness, prédios de escritórios, bancos, aeroportos, shopping centers e laboratórios de genética" (HAN, 2017, p. 23). Podendo ser acrescentadas nessa lista clínicas de estética, companhias farmacêuticas, literatura de autoajuda, redes sociais digitais, novas identidades, práticas ${ }^{85}$ individuais e grupais, tais como "[...] grupos portadores de neurofibromatose, $[\ldots]$ grupos formados em torno do cromossomo 17 , locus 16.256 , sítio 654.376 , alelo com substituição de uma guanina" (RABINOW, 1999, p. 147), entre vários empreendimentos que estimulam certa positividade do "desempenho" " E os indivíduos, nesse contexto, tornam-se, pouco a pouco, figuras cifradas, decodificáveis e transformáveis.

Em certa medida, essa rearticulação do poder corrobora o que Deleuze $(1992$, p. 2) já houvera dito ao sinalizar uma crise generalizada de todos os meios disciplinares e/ou de confinamento, isto é, prisão, hospital, fábrica, escola, família etc., anunciando o aparecimento de novas forças de condução e controle "[...] a empresa substitui a fábrica, e a empresa é uma alma, um gás. [...] a empresa introduz o tempo todo uma rivalidade inexpiável como sã emulação, excelente motivação que contrapõe os indivíduos entre si e atravessa cada um, dividindo-o em si mesmo".

A expressão "Yes, we can", explorada na campanha eleitoral de 2008 nos Estados Unidos, parece encaixar-se perfeitamente ao caráter desse sentimento atual de positividade que, apesar de distinto da obediência disciplinar, acaba por apontar para uma continuidade do mesmo projeto econômico de maximização da produtividade: “A positividade do poder é bem mais eficiente que a negatividade do dever. [...] o sujeito de desempenho é mais rápido e mais

\footnotetext{
${ }^{84}$ Devemos considerar, no entanto, que, apesar de Han (2017) se referir a "negatividade da proibição" e, desse modo, sugerir uma negatividade da disciplina, não assumimos essa mesma premissa. A disciplina, tal como mostrado por Foucault (2013d), é marcadamente positiva e produtiva. O objetivo de trazer Han (2017) para esse debate é apenas para sinalizar alguns signos do que estamos entendo por rearticulação contemporânea do poder, principalmente observando o aparecimento de novos espaços de docilização e potencialização da produtividade. Se o poder disciplinar, entre os séculos XVI e XVIII, fora exercido positivamente, agora os meios para o seu exercício estão tornando-se cada vez mais sutis e ramificados.

${ }^{85}$ Práticas grupais estão surgindo por meio de debates realizados em redes sociais conectadas por internet. Fazendo uma consulta rápida no Facebook, por exemplo, encontramos as seguintes associações que promovem fóruns de debate: Associação Brasileira do Déficit de Atenção, Associação de Apoio aos Doentes Depressivos e Bipolares, Associação Portuguesa de Síndrome de Asperger, Associação Síndrome de Down.

${ }^{86}$ Segundo Han (2017), a sociedade do século XXI não é mais a sociedade disciplinar, mas uma sociedade de desempenho. Também seus habitantes não se chamam mais "sujeitos da obediência", mas sujeitos de desempenho e produção. São empresários de si mesmos. "Nesse sentido, aqueles muros das instituições disciplinares, que delimitam os espaços entre o normal e o anormal, se tornaram arcaicos. A analítica do poder de Foucault não pode descrever as modificações psíquicas e topológicas que se realizaram com a mudança da sociedade disciplinar para a sociedade do desempenho. Também aquele conceito da 'sociedade de controle' não dá mais conta de explicar aquela mudança. Ele contém ainda muita negatividade” (HAN, 2017, p. 23-24).
} 
produtivo que o sujeito da obediência" (HAN, 2017, p. 25).

Cabe notar, no entanto, como sugere Han (2017), que essa positividade de estímulos é responsável - no contexto do cerebrocentrismo - pelo surgimento de uma onda de enfermidades neurais como depressão, TDAH, Transtorno de personalidade limítrofe (TPL) ou Síndrome de Burnout (SB), o que conduz à ideia de que a sociedade disciplinar embora gere loucos e delinquentes, diferencia-se da sociedade do desempenho, que, ao contrário, "produz depressivos e fracassados" (HAN, 2017, p. 25), pessoas que estão sempre correndo atrás de sua própria sombra: "Muitos jovens pedem estranhamente para serem 'motivados', e solicitam novos estágios e formação permanente" (DELEUZE, 1992, p. 4).

Por sua vez, para Ehrenberg (2010), essa nova mentalidade torna-se perceptível quando a simples realização do dever profissional começa a ser desvinculada dos valores espirituais e culturais e passa a ser associado aos ideais de competividade ${ }^{87}$ do esporteaventura: "o esporte saiu dos estádios e ginásios; ele abandonou o contexto restrito das práticas e dos espetáculos esportivos: é um sistema de condutas de si que consiste em implicar o indivíduo na formação de sua autonomia e de sua responsabilidade" (EHRENBERG, 2010, p. 18). Segundo o autor, o casamento do esporte com a aventura é uma resposta à crise da ação pública centralizada e um dos elementos na formação de um tipo privado de civismo, uma "política fora da cidadania", em que cada indivíduo é obrigado a assumir as responsabilidades que a ação pública já não é mais capaz de assumir (EHRENBERG, 2010, p. 16). Nesse cenário, o esporte transforma-se em uma referência importante para a construção da imagem de um indivíduo ideal: forte, competitivo, empreendedor, autônomo. Com isso, a identidade do sujeito tende a transparecer em suas realizações pessoais - "o homem de sucesso", “o vencedor", ou, ainda, “o perdedor", “o fracassado" -, e a importância dada ao desempenho transforma a busca pela ótima performance em uma exigência quase imediata ${ }^{88}$.

O centro dessa mitologia que une performance e autonomia está nas transformações da narratividade esportiva: ela rompeu com a moral disciplinar da submissão a interesses superiores - à pátria, a Deus, ao

\footnotetext{
${ }^{87}$ A competição, segundo Foucault (2008), constitui o princípio de inteligibilidade do neoliberalismo.

${ }^{88}$ No esporte, em virtude do alto nível de competitividade, muitos são levados, mesmo que ilegalmente, a se submeter ao doping para aumentar suas performances. Já, fora do esporte, no mundo do trabalho, mas movidos pela mesma lógica do alto desempenho, os indivíduos tendem a buscar recursos que lhes permitam maior competitividade no mercado, e o mercado, por sua vez, os estimulam em prol de uma maior produtividade. Há um uso crescente, por exemplo, de produtos farmacológicos e estimuladores cognitivos (nootrópicos ou "smart drugs") que permitem aos indivíduos maior tempo acordados, aumentar a atenção, a memória etc. Disponível em: http://www.bbc.com/portuguese/noticias/2015/07/150726_nootropicos_ab. Acesso em: 1 maio 2018.
} 
homem novo. Hoje, o esporte é um aspecto da "galáxia da autonomia": não mais uma obrigação que nos é imposta em nome de qualquer coisa superior a nós, mas uma liberação que se impõe a si em nome de si mesmo, de sua saúde, de seu estresse, de sua aparência física etc. (EHRENBERG, 2010, p. 23).

No contexto dessa racionalidade - à qual irá se somar a molecularidade, a transparência, a autonomia, o desempenho, o "chegar primeiro" e também o cérebro -, o indivíduo é estimulado a promover um trabalho de si sobre si próprio, é exigido que ele se torne um "empresário de si mesmo", mais eficiente e adaptável. De outro modo, a política da vida atual caracteriza-se por ser uma política da vida nela mesma (politics of life itself) (ROSE, 2013, p. 16) e está voltada particularmente para a possibilidade de cada indivíduo "controlar, administrar, projetar, remodelar e modular" suas vitalidades, tornando-se potencialmente competitivo no processo de produtividade. A novidade ${ }^{89}$, então, como já apontada por Rose (2013), está relacionada aos problemas que dizem respeito a uma otimização da vida, na possibilidade de cada indivíduo poder incrementar seu corpo e sua mente.

Nessa direção, por exemplo, Ribeiro (2003) refere que a medicina atual vem propondo não a volta a uma situação anterior, ainda que mítica, não está querendo zerar a doença, propõe o mais: "uma felicidade maior do que antes. E isso está no cerne dos projetos Genoma, das neurociências, até da clonagem: ser capaz de ir além do que jamais se foi" (RIBEIRO, 2003, p. 29). E sobre as possibilidades que estão sendo abertas o autor afirma que nada impede que novos saberes possam ser usados para melhorar a raça, "aumentando a altura de nossos netos, tornando-os mais magros, quem sabe até - neste país moreno de gostos esquisitos, amante a um tempo das nádegas grandes e dos cabelos claros - aloirando os nossos nenês" (RIBEIRO, 2003, p. 29).

Mesmo se assemelhando, em alguns casos, a imagens de ficção científica, exemplos de remodelação e otimização somática cotidianamente são apresentados no universo da pesquisa científica. Dessa forma, ao discutir sobre o pós-humanismo ${ }^{90}$ e o transumanismo ${ }^{91}$,

\footnotetext{
${ }^{89}$ Ainda que as tentativas de melhorar o desempenho humano sejam antigas - poções e chás para produzir força, potência e sabedoria aparecem nos mitos de quase todas as culturas, como relatado nas histórias em quadrinhos que apresentam os feitos de personagens Asterix e Obelix, então em 50 a.C, em Roma, entre outros -, o que se apresenta como novo é o uso de medicamentos que foram feitos originalmente para corrigir disfunções, como Parkinson e Alzheimer, no incremento de certas capacidades humanas. Além disso, há uma submissão das tecnologias de melhoramento da vida à lógica econômica.

${ }^{90}$ Segundo Proust (2009, p. 348), o pós-humanismo, tal como apresentado por Sloterdijk, representa um "esforço clássico de educação, mas através de novos meios: utilizando todas as novas técnicas agora disponíveis, até mesmo e inclusive a modificação artificial do potencial genético". É um sistema de valores apresentado como aquele que deve substituir os valores do humanismo.
} 
Proust (2009) faz referência a algumas pesquisas curiosas, como a do especialista em informática Kevin Warwick, que já há algum tempo estaria promovendo uma espécie de fusão do orgânico com a máquina: “Um ser humano 'implantado', dispondo de um estimulador cardíaco, de um implante cocler, de uma prótese articulatória" (PROUST, 2009, p. 349). O próprio Warwick teria implantado em si mesmo, ainda em 2002, um microprocessador nos nervos medianos do braço esquerdo, o que lhe permitiu colocar seu sistema nervoso em relação com vários computadores, conectados ou não pela internet, e com outros seres humanos.

[...] uma conexão de internet ligou-o a um robô que estava na sua universidade, em Reading, na Inglaterra. O objetivo do espetáculo era anunciar ao mundo (aos jornalistas que irão divulgar a notícia) que Warwick sente na ponta de seus próprios dedos, em Columbia, a forma dos objetos manipulados pelo robô em Reading, de acordo com suas intenções de ação, em Columbia. (PROUST, 2009, p. 349).

Além disso, Proust (2009, p. 351) comenta sobre os sistemas de substituição sensorial, como o desenvolvido por Paul Bach-y-Rita ${ }^{92}$, que permitem a um deficiente visual aprender a identificar objetos à sua volta e localizá-los por meio de captadores que recolhem os sinais na modalidade defeituosa, "um sistema de acoplagem transforma esses sinais em estímulos interpretáveis pelo indivíduo, que os percebe, por exemplo, sob a forma de ondas sonoras ou estímulos táteis". Há também os sistemas de substituição neuromotores que usam a plasticidade cerebral para desenvolver e explorar equivalências intermodais, "visam conseguir restituir uma forma de mobilidade a um indivíduo que não a tem mais, e até mesmo lhe conferir formas de mobilidade supranumerárias relativas à anatomia natural" (PROUST, 2009, p. 354, grifo nosso). Exemplo disso são as pesquisas e os protótipos desenvolvidos pelo neurocientista brasileiro Miguel Nicolelis ${ }^{93}$.

\footnotetext{
${ }^{91} \mathrm{O}$ transumanisno estaria menos centrado em uma crítica filosófica sobre a natureza e o alcance do humanismo do que na "esperança do desenvolvimento técnico (em engenharia genética, nanotecnologias, robótica e realidade virtual) para ultrapassar os limites ligados à evolução biológica (velhice, sofrimento, reprodução, etc.)" (PROUST, 2009, p. 348).

${ }_{92}$ Para mais detalhes, conferir: http://ofuturodascoisas.com/hackeando-seus-sentidos-para-novos-superpoderes/. Acesso em: 12 abril 2018.

${ }^{93}$ Em um experimento famoso, Miguel Nicolelis fixou eletrodos - Brain-Machine Interface - no cérebro de um macaco preso diante de uma TV. Com um dispositivo de entrada, do tipo usado em jogos de computador, o macaco comandou durante algum tempo formas que se moviam na TV e, quando coordenadas adequadamente, liberavam alimentos para o animal. Oculto do macaco estava um braço mecânico, que ele comandava com o dispositivo de entrada e tinha a sua posição indicada por uma das formas que ele via na TV. Quando o modelo de experimento alcançou um grau de predição aceitável, Nicolelis transferiu o controle para o cérebro do macaco e desligou o dispositivo de entrada. O macaco logo deixou de manipular o dispositivo e começou a usar o braço mecânico. Bastava "pensar" em mover as imagens na TV e o braço mecânico se movia (Proust, 2009). Outro
} 
Entre outros exemplos de correção e otimização somática citados por Proust (2009), merecem destaque ainda os dispositivos de ampliação cognitiva, em especial os direcionados para o melhoramento da atenção. A atenção é tida por pesquisadores cognitivistas e especialistas em educação como sendo a base de sustentação do sucesso escolar e dos aprendizados sociais (PROUST, 2009). Partindo dessa hipótese e de imagens cerebrais que permitem distinguir as diferenças e localizar eventuais lacunas das funções cognitivas, pesquisadores nas áreas da neuroeducação, neurociência cognitiva e computação se esforçam na produção de trabalhos experimentais com softwares computacionais ${ }^{94}$ que demonstram os efeitos de certos exercícios cerebrais no desenvolvimento da inteligência individual.

A criança de 4 anos treinada em cinco sessões de meio dia em videogames concebidos para desenvolver sua memória executiva (inibição das distrações, reconhecimento dos sucessos e dos fracassos, concentração da atenção em uma tarefa) internaliza por longo tempo os métodos de exploração e de fixação da atenção que lhe são propostos e atinge dois anos antes - ou seja, aos 6 anos - a capacidade de atenção normal de uma criança de 8 anos não submetida a esse treino. (PROUST, 2009, p. 360).

A projeção desses dispositivos, em linhas gerais, parte da premissa de que o cérebro é um músculo como "qualquer outro" e, sendo assim, quanto mais é exercitado, mais forte ele fica $^{95}$. Uma reportagem publicada na revista $E^{\prime}$ oca $^{96}$ (LAWTON; MOON; SILVEIRA, 2008),

experimento de Miguel Nicolelis foi na Copa do Mundo de 2014, quando, com a ajuda de um exoesqueleto e dispositivos acoplados no cérebro de um paraplégico, ele projetou o chute inaugural do evento.

${ }^{94}$ Atualmente existem vários programas computacionais que prometem melhorar o desempenho cognitivo por meio de exercícios cerebrais. Fizemos uma rápida pesquisa na internet e encontramos alguns exemplos: 1. Fit Brains Trainer: a proposta do aplicativo é estimular a concentração, memória, velocidade de raciocínio e a lógica, com 360 sessões de treinamento. O aplicativo já foi baixado mais de 4 milhões de vezes; 2. Lumosity: combina mais de 25 jogos cognitivos em programas para treinar diariamente. Com 70 milhões de usuários pelo mundo, os games adaptam-se conforme o desempenho dos usuários. Cada um deles tem uma função específica, como melhorar a memória e a solução de problemas; 3. Menrise: sua habilidade apresenta-se em turbinar a memória, mas com foco no aprendizado de idiomas. Os desenvolvedores do programa dizem que a técnica permite ao cérebro aprender até 44 palavras por hora. As metas de aprendizado são personalizadas para cada usuário, que é informado periodicamente sobre o melhor momento para revisar as palavras. Disponível em: https://oglobo.globo.com/sociedade/educacao/guiaenem/sete-aplicativos-para-exercitar-cerebro-19975853.

Acesso em: 12 abr. 2018.

${ }^{95}$ Curiosamente, esse assunto vem sendo bastante explorado em reportagens direcionadas para o público "empreendedor". Em um artigo da revista Época Negócios, vemos as seguintes recomendações: a) aprenda uma nova habilidade que se encontra fora da sua zona de conforto, "fazer as mesmas tarefas da mesma forma todos os dias não traz desafios para que o cérebro se renove"; b) pegue o caminho mais longo até sua casa e comece a reparar em cada detalhe ao seu redor, "isso irá engajar o hipocampo do cérebro, que é justamente o campo de aprendizado e memória"; c) exercite-se e coma direito, "será difícil manter um cérebro em pleno funcionamento se o seu corpo está gastando energia lutando com outros elementos, como pressão alta". Enfim, o homem de negócios agora se tornou um cérebro de negócios. Disponível em: https://epocanegocios.globo.com/Curiosidades/noticia/2017/09/os-jogos-que-estimulam-o-cerebro-vao-muitoalem-da-memorizacao.html. Acesso em: 12 abr. 2018.

${ }^{96}$ Disponível em: http://revistaepoca.globo.com/Revista/Epoca/0,EMI9017-15224,00.html. Acesso em: 12 abr. 2018. 
por exemplo, informa que todos os fabricantes de games de exercícios cerebrais defendem a eficácia de seus produtos, e os argumentos seriam basicamente dois. Eles oferecem melhoria do funcionamento cerebral - como atenção, memória e velocidade de processamento - ou retardamento do declínio inevitável decorrente do envelhecimento. A ideia básica, então, é de que os processos cognitivos podem ser otimizados e o cérebro pode ser arbitrariamente moldado, colaborando, desse modo, com um aumento nas performances mentais. $\mathrm{O}$ interessante da reportagem é que ela permite, em certo aspecto, confirmar essa nova racionalidade que promove o trabalho de cada um sobre si próprio, principalmente ao sugerir que o indivíduo tem que decidir por si mesmo: "turbina" o cérebro ou "corre o risco de ser passado para trás por alguém que se tornou mais esperto porque aderiu à nova mania" (LAWTON; MOON; SILVEIRA, 2008).

Ainda sobre esses mesmos dispositivos, outra modalidade que estaria atualmente sendo desenvolvida - algumas em estágios iniciais - seriam as técnicas invasivas de remodelação cognitiva, como o estímulo cerebral profundo ${ }^{97}$ (Deep Brain Stimulation - DBS), o estímulo do nervo vago ${ }^{98}$ (Vagus Nerve Stimulation - VNS) e os dispositivos neuronais artificiais destinados a hibridizar ${ }^{99}$ os conjuntos de neurônios biológicos. Esses empreendimentos, além de apresentarem objetivos correcionais, visam, em grande medida, estender as competências mentais para além do aprendizado individual não invasivo. "Poderemos desejar melhorar nosso raciocínio, nossa capacidade de planificar ou o ajuste dos nossos afetos. Talvez um dia possamos escolher entre os dispositivos artificiais de ampliação cognitiva, como escolhemos hoje o computador que melhor se adapta às nossas necessidades" (PROUST, 2009, p. 364).

Assim, desde a manipulação genética, passando por projetos de hibridização do orgânico com o mecânico, por softwares que prometem "turbinar" o cérebro e por técnicas invasivas de ampliação cognitiva - além de produtos psicofarmacológicos que prometem remodelar a cognição e os afetos -, uma gama de trabalho está sendo desenvolvida sob o signo de uma nova racionalidade, a neoliberal, na qual a palavra de ordem parece ser a do

\footnotetext{
${ }^{97}$ Segundo Proust (2009), o dispositivo compreende três elementos: um gerador que emite impulsos elétricos (dispositivo a pilha implantado sob a pele no tronco do paciente), um fio encapado de poliuretano e um pequeno número de eletrodos implantado no cérebro. $\mathrm{O}$ dispositivo permite estimular as partes do cérebro nas quais os eletrodos foram inseridos.

${ }^{98}$ Um pequeno dispositivo elétrico implantado no corpo do paciente envia permanentemente impulsos elétricos para o cérebro (uma vez a cada cinco minutos). Os eletrodos implantados têm a função de analisar a atividade cerebral e detectar a iminência de uma crise (PROUST, 2009).

99 A tecnologia adotada é a Very Large Scale Integration (VLSI), por meio da qual circuitos integrados combinam milhares de circuitos a transistor em um só microprocessador. A utilização dessa tecnologia (primeiro passo para a nanorrobótica cerebral) permite construir microcircuitos de silicone tendo um comportamento funcional análago ao de dez mil neurônios; eles se destinam a ser implantados no hipocampo (PROUST, 2009).
} 
autoempreendimento, em conformidade com a ideia de que cada um deve ser empresário de si mesmo - o indivíduo é quem deve responder pelo incremento de sua performance, é ele quem deve fazer um "investimento subjetivo de si na sua matéria” (ORTEGA, 2008a, p. 64).

Ora, em princípio não há nada de errado em querer melhorar a si mesmo, nem investir em pesquisas que notadamente, além de otimizar, podem corrigir déficits somáticos que dificultam a vida das pessoas. O problema, no entanto, surge quando esses empreendimentos passam a ser pensados quase que exclusivamente em virtude de uma lógica econômica, mais especificamente de uma economia neoliberal que parece governar, ao mesmo tempo, a "mentalidade" do geneticista, do programador de softwares, do biólogo, do pesquisador em robótica, do psicólogo, do neuroeducador, do cientista cognitivo, do agricultor de produtos transgênicos, do granjeiro, entre outros, e isso de acordo com os interesses do mercado e em razão da normalização das condutas, viabilizando uma alocação de "recursos raros para fins que são concorrentes, isto é, para fins que são alternativos, que não podem se superpor uns aos outros" (FOUCAULT, 2008b, p. 306).

Apesar de a comparação ser um pouco estranha, é possível dizer que na mesma direção em que muitos proprietários de granjas têm investido em tecnologias, como as genéticas e as medicamentosas, reduzindo o ciclo de produção e aumentando o fluxo de venda ${ }^{100}$ de seus produtos (aves), algo parecido está acontecendo também no universo das relações humanas, mas, em vez de simplesmente antecipar o crescimento biológico e potencializar um tipo de vida contraditoriamente em nome do "abate", e, é claro, do lucro, procedimentos similares são sugeridos aos seres humanos em nome da formação de recursos raros, ou de bons equipamentos humanos, mas agora não sendo apenas os genéticos, senão aqueles que podem ser incrementados por vias mecânicas, medicamentosas e educacionais. Importante retomar a citação, agora ressaltando quando o autor registra que a criança treinada "[...] atinge dois anos antes - ou seja, aos 6 anos - a capacidade de atenção normal de uma criança de 8 anos não submetida a esse treino" (PROUST, 2009, p. 360, grifo nosso). Ainda, em uma sociedade na qual o trabalhador está sendo obrigado a se aposentar aos 65 anos, ou mais, retardar o declínio cognitivo e manter-se produtivo não é uma simples alternativa, é um imperativo moral.

De algum modo, o processo de otimização da vida tornou-se sinônimo de produção de

\footnotetext{
${ }^{100}$ Em outros tempos, por exemplo, abatiam-se animais com idade, em média, de 60 e 90 dias, mas atualmente a idade de abate é entre 40 e 45 dias. Disponível em: https://www.em.com.br/app/noticia/economia/2014/12/15/internas_economia,599529/criadores-de-frangosutilizam-tecnicas-que-reduzem-a-metade-o-tempo-pa.shtml. Acesso em: 13 maio 2018.
} 
potencial de produção. Afinal, até que ponto o investimento na vida tem ocorrido em função dela mesma e não daquilo que ela pode vir a produzir para o mercado? Por que não valorizar, por exemplo, a desatenção e os desatentos, o esquecimento e os com pouca memória? Ou, ainda, em que medida é interessante antecipar a capacidade de atenção normal de uma criança ou retardar o declínio cognitivo de um idoso, se o objetivo não for o de simplesmente fazer brincar, ou captar a "aura" de um pôr do sol em uma tarde de outono, vivenciar o sentimento demasiado humano nos detalhes dos versos de um poema e/ou no prazer estético da beleza matemática, mas tão somente o de criar no ser humano uma competência-máquina?

\footnotetext{
Sabe-se perfeitamente que o número de horas que uma mãe de família passa ao lado do filho, quando ele ainda está no berço, vai ser importantíssimo para a constituição de uma competência-máquina, ou se vocês quiserem para a constituição de um capital humano, e que a criança será muito mais adaptável se, efetivamente, seus pais ou sua mãe lhe consagraram tantas horas do que se lhe consagraram menos horas. Ou seja, o simples tempo de criação, o simples tempo de afeto consagrado pelos pais a seus filhos, deve poder ser analisado em termos de investimento capaz de constituir um capital humano. (FOUCAULT, 2008b, p. 315).
}

A questão é que o axioma da política da vida contemporânea, tal como apontado por Foucault (2008b) em Nascimento da biopolítica, pelo menos desde o segundo pós-guerra, parece não se encontrar mais na dependência dos incentivos e das ações de uma política estatal centralizada. Para a biopolítica neoliberal, "é preciso governar para o mercado, em vez de governar por causa do mercado" (FOUCAULT, 2008b, p. 165). Como é sabido, os rastros dessa racionalidade foram analisados pelo filósofo francês quando ele percebeu que entre o liberalismo dos séculos XVIII e XIX e o neoliberalismo do século XX ocorrera uma espécie de mutação epistemológica. Se no liberalismo do tipo Adam Smith, a análise econômica tinha como objeto o estudo dos mecanismos de produção, os mecanismos de troca e os fatos de consumo no interior de uma estrutura social dada, no neoliberalismo a análise econômica passou a ser direcionada para outro foco, para o estudo e a análise da maneira como são alocados os recursos raros, ou como "as diferenças qualitativas de trabalho podem ter um efeito do tipo econômico" (FOUCAULT, 2008b, p. 307).

Em outros termos, e de certa forma atualizando elementos da análise foucaultiana, a possibilidade de melhoramento genético por meio de intervenções moleculares, de remodelação somática promovida pela medicina, pela cultura fitness e pelas tecnologias de hibridização, de potencialização de processos cognitivos, como atenção, memória, inteligência, intencionalidade, volição etc. - que tende a ser feita, paralelamente, por 
tecnologias como as computacionais, ginásticas cerebrais e produtos de companhias farmacêuticas que adentram as nossas casas e os espaços formais da educação -, e muitos outros procedimentos de otimização da vida ${ }^{101}$ constituem, em linhas gerais, empreendimentos que visam à formação de recursos raros ou, como sugerimos, à produção de potenciais de produção, notadamente os que são voltados para o mercado ${ }^{102}$.

Nesse registro, vale a pena destacar a ocorrência de uma espécie de junção entre uma racionalidade governamental, ou governamentalidade biopolítica, que estimula o incremento de capacidades vitais que podem ser aproveitadas pelo mercado, como as genéticas e as cognitivas, mas também aquelas que são desenvolvidas por meio da educação, isto é, o capital mental adquirido, e o desenvolvimento tecnológico que possibilita esses mesmos incrementos. Em meio a isso, ocorre algo que podemos classificar como sendo uma espécie de "ilusão de escolha", pois, se pelo intermédio de critérios definidos por regras do mercado passamos a considerar nossas capacidades, habilidades e aptidões como recursos passíveis de incremento e valorização, então acabamos por selecionar apenas aquilo que nos deve favorecer no espaço de competição do próprio mercado. No entanto, ao fazer essa seleção, reforçamos em nosso próprio processo de subjetivação não o que pensamos propriamente escolher como o mais viável para nós mesmos, mas sim o que o mercado planejou para que escolhêssemos como sendo o melhor para o próprio mercado.

O que estamos notando, então, seguindo a esteira do pensamento de Foucault (2008b), é que o próprio indivíduo está sendo convertido, pouco a pouco, e de forma mais ou menos consciente, em capital. As suas competências, habilidades e aptidões, as quais podem ser racionalmente incrementadas e potencializadas, passam a fazer parte de um cálculo econômico, político e científico, e investir em si mesmo torna-se, sobretudo, sinônimo de fortalecimento do mercado. Assim, enquanto no período do liberalismo econômico, tal como

\footnotetext{
${ }^{101}$ Esse processo de otimização pode ser compreendido pela perspectivà pa de investimentos em elementos, inatos e adquiridos, que compõem o capital humano (FOUCAULT, 2008b).

${ }^{102}$ Para exemplificar, podemos citar trechos de propaganda de um método de auxílio educativo, o Supera, desenvolvido no Brasil, voltado para melhorar o desempenho cognitivo de seus clientes, o qual recorrentemente enfatiza a importância da produção de potencial para o mercado. "O SUPERA usa várias ferramentas para fortalecer conexões neurais. Uma vez fortalecidas, essas conexões beneficiarão os alunos em suas atividades em casa, no trabalho e na escola em termos de qualidade de vida e melhora no desempenho. Essas conexões estão relacionadas a várias habilidades como: a atenção e a concentração, o raciocínio lógico-matemático, a memória e a habilidade viso espacial, além de estimularem o relacionamento intra e interpessoal, tão valorizados pelo mercado nos dias de hoje" (2018, grifo nosso). Disponível em: http://metodosupera.com.br/wp-content/uploads/2009/09/Fundamenta\%C3\%A7\%C3\%A3o-Te\%C3\%B3rica.pdf. Acesso em: 4 maio 2018. "O SUPERA é um curso diferente de tudo que você já conhece. Com apenas uma aula semanal de duas horas, você conquista uma mente saudável, com mais concentração, raciocínio, memória, criatividade e autoestima. Estas habilidades melhoram o desempenho na escola, alavancam a carreira e garantem mais qualidade de vida" (2018, grifo nosso). Disponível em: http://metodosupera.com.br/. Acesso em: 4 maio 2018 .
} 
apontado por Foucault (2008b), o capital reteve do trabalho a força e o tempo, agora ele tende a reter também a "mente"103 e/ou a "alma" do próprio trabalhador. "Decomposto do ponto de vista do trabalhador, em termos econômicos, o trabalho comporta um capital, isto é, uma aptidão, uma competência; [...] é uma 'máquina'. E, por outro lado, é uma renda, isto é, um salário ou, melhor ainda, um conjunto de salários; como eles dizem: um fluxo de salários" (FOUCAULT, 2008b, p. 308). Trata-se, desse modo, de um regime de construção de identidade fundamentado na ideia de homo oeconomicus, capital humano, sociedade empresarial, mercado competitivo, esporte-aventura, o qual irá se somar, contemporaneamente, à ideia de um sujeito cerebral.

No Reino Unido, a soma dessa ideia ${ }^{104}$ é a de capital mental, e o argumento é que as sociedades e os políticos têm que maximizar o capital mental de suas populações, encorajando as pessoas a maximizar seu bem-estar por meio da compreensão de todo tipo de problemas sociais - quer sejam problemas de práticas educativas na infância, ou problemas de agressão - em termos de coisas do cérebro; procurando agir sobre, por meio do cérebro - governar pelo cérebro. (ROSE, 2013, p. 311).

Nessa direção, o indivíduo na sociedade empresarial, "autônomo" e "empreendedor", curiosamente é impelido, incentivado e, em alguma medida, forçado a "controlar, administrar, projetar, remodelar e modular" (ROSE, 2013) a sua vitalidade - ou seja, aceita o estimulante para se manter ativo ou perde o trabalho de entrega ao correr o risco de chegar atrasado -, tornando-se, assim, empresário de si mesmo, "sendo ele próprio seu capital, sendo para si mesmo seu produtor, sendo para si mesmo a fonte de sua renda" (FOUCAULT, 2008b, p. $311)$.

Vemos, desse modo, que a vida mesma se tem transformado em objeto político, que o poder, molecularmente, a tomou de assalto (PELBART, 2007), invadiu os genes, os neurônios e todos os detalhes do corpo, a res extensa. De acordo com Lazzarato (1999), para além dos processos biológicos, o biopoder passou a dominar também aquilo que é anorgânico, isto é, o tempo e suas virtualidades, "não o tempo abstrato, o tempo medida, mas o tempo-potência, o tempo como 'fonte de criação contínua de imprevisíveis novidades', 'aquilo que faz com que tudo se faça"” (LAZZARATO, 1999, p. 81). De outra forma, o biopoder invadiu a dimensão

\footnotetext{
${ }^{103}$ Para que não seja suscitada aqui nenhuma dúvida, entendemos por mente e/ou alma os efeitos das relações das propriedades mais "sutis" da materialidade do corpo, ou certa faculdade intelectiva e afetiva que pode ser lida em neurônios, neurotransmissores, sinapses, hormônios etc. Com isso, queremos evitar debate sobre qualquer forma de dualismo.

${ }^{104}$ Por um lado, o cérebro é tido como um órgão formatado socialmente e, por outro, é tido como um recurso social muito importante (ROSE, 2013).
} 
humana, que até o final da modernidade foi reconhecidamente atrelada à res cogitans, isto é, chegou ao espírito ${ }^{105}$, à racionalidade e à inteligência, tomando conta da intencionalidade, da imaginação, da criatividade, da capacidade de inovação, atingiu o tempo da vida, a duração da atenção, e "[...] mesmo o sexo, a linguagem, a comunicação, a vida onírica, mesmo a fé" (PELBART, 2007, p. 58), invadiu também os instantes de vida em que uma mãe deve dispensar ao filho, adentrou em seu tempo de afeto. Mas, além de invadir, o bipoder tende também a reconfigurar esses mesmos espaços e, com eles, o próprio tempo - os pertencentes à res extensa e os que não eram específicos da res cogitans, mas que agora poderiam ser -, e ao realizar esse feito obedece a uma lógica essencialmente econômica, e a economia, é importante lembrar, já não é "a análise da lógica histórica de processo, é a análise da racionalidade interna, da programação estratégica da atividade dos indivíduos" (FOUCAULT, 2008b, p. 307). Ou, de outro modo:

A ciência econômica, nesse caso, não cria só uma teoria sobre a economia; cria um repertório de interpretação que nos permite pensar e pensar-nos de maneira tal que não nos resulte repulsiva a imagem do humano como riqueza - como o havia sido em tempos de J. S. Mill. A partir de seus postulados "cientificamente verificáveis", o humano passa a ser entendido como uma forma de capital e, portanto, o "capital humano" e tudo o que se faça para incrementá-lo é investido de um valor positivo: cada pessoa deve - porque é economicamente conveniente, mas também porque é "moralmente bom" aumentar suas habilidades, competências e destrezas a partir de "investimentos" constantes. (LÓPEZ-RUIZ, 2007, p. 38).

É nesse cenário, por exemplo, que Johathan Crary (2016), em seu livro intitulado 24/7 - o capitalismo tardio e os fins do sono, curiosamente fala sobre um projeto de pesquisa norte-americano desenvolvido em âmbito militar que ilustra bem o sintomático desejo de reconfiguração das capacidades vitais, em especial as relacionadas ao sono, e, mais ainda, demonstra uma tentativa de capitalização dos intervalos do tempo da vida. O ponto de partida desse projeto é o estudo de um tipo particular de ave migratória, o pardal-de-coroa-branca. Diferente de outros pássaros, ele possui a capacidade de permanecer acordado por até sete dias durante sua migração, o que lhe permite voar e navegar à noite e procurar por alimentos no decurso do dia, sem descansar. A intenção dos pesquisadores é compreender o funcionamento da atividade cerebral desse pássaro - o real motivo que o faz ficar por tanto tempo acordado e, ainda assim, ativo - e, posteriormente, usar e ampliar esse conhecimento

\footnotetext{
${ }^{105}$ Para distinguir o poder que atua sobre o "orgânico", o biopoder, do poder que atua sobre o "espírito", Lazzarato (2006) criou o neologismo noopoder (noopolítica). Segundo esse autor, noûs é o termo com que Aristóteles designa a parte mais elevada da alma, do intelecto.
} 
em seres humanos, de início fazendo com que um soldado fique pelo menos sete dias sem dormir, e, em prazo mais longo, duplicando esse período, "preservando níveis altos de desempenho mental e físico" (CRARY, 2016, p. 12).

No entanto, como o próprio Crary (2016, p. 13) reconhece, muitas inovações relacionadas à guerra têm sido historicamente assimiladas na esfera social, então não é muito difícil imaginar que o soldado sem sono possa vir a ser "o precursor do trabalhador ou do consumidor sem sono". Assim, independentemente de qualquer exagero, em uma época na qual o mercado governa as condutas, ou em que é "preciso governar para o mercado" (FOUCAULT, 2008b, p. 165), e ainda quando o próprio indivíduo é convertido em capital humano, em relação ao trabalho, torna-se plausível, até mesmo normal, a ideia do trabalho sem pausa, sem limites. Afinal, como dizem muitos economistas, "tempo é dinheiro" - e pelo que parece o intervalo também pode ser capitalizado. Em contraposição, o consumo torna-se atemporal: "Agora nossos corpos e identidades assimilam uma superabundância de serviços, imagens, procedimentos e produtos químicos em nível tóxico e muitas vezes fatal" (CRARY, 2016, p. 19).

Assim, desde os detalhes mais fundamentais do corpo até as faculdades intelectivas, afetivas, volitivas, e mesmo o modo de experimentar o tempo e seus intervalos, foram todos contemporaneamente investidos pelo poder ${ }^{106}$, que então "pilota nossa vitalidade social de cabo a rabo" (PELBART, 2007, p. 58), nos propõe correções, além da vigilância de nossas suscetibilidades, produz cálculos de risco, cria condições tecnológicas para remodelação e potencialização de habilidades e nos transfere a responsabilidade de intensificar e otimizar a vida: "Nós próprios nos encarregamos de administrar nosso controle, e o próprio desejo se vê inteiramente capturado. Nunca o poder chegou tão longe e tão fundo no cerne da subjetividade e da própria vida, como nessa modalidade contemporânea de biopoder" (PELBART, 2007, p. 58).

É dentro desse contexto - no qual a expressão "o poder tomou de assalto a vida" (PELBART, 2007, p. 6) mostra-se significativa, mediante o aparecimento de novos saberes, como os moleculares, além da transferência para o indivíduo da responsabilidade com a própria saúde e otimização da vitalidade - que percebemos a inserção da figura antropológica do sujeito cerebral e/ou do self-neuroquímico. O cérebro aparece, nessa direção, como um atrator no processo de produção de capital humano, um dispositivo do biopoder. E, uma vez que, a olhos vistos, vem ocupando um lugar especial nas práticas e discursos contemporâneos,

${ }^{106}$ Se anteriormente o poder moldava os corpos, imprimindo-lhes uma disciplina e regulando a população, agora ele tende a reconfigurar os cérebros, modulando o sono, a memória, a atenção, a inteligência e os afetos. 
principalmente os relacionados à representação de individualidade e subjetividade, o convite para corrigir, treinar e melhorar esse sujeito - seja por meio de medicamentos, ginásticas cerebrais, métodos invasivos e até mesmo autoajuda cerebral - torna-se, singularmente, uma proposta biopolítica.

\subsection{INVESTINDO EM NOSSOS SELVES}

Retomando alguns pontos, temos que: enquanto na gênese do liberalismo ${ }^{107}$ existe aquilo que Foucault (2008b) denomina de poder disciplinar, com seus mecanismos de vigilância, adestramento, regulação das condutas, correção de desvios, ampliação de aptidões, entre outros, apoiados "[...] mais nos corpos e seus atos do que na terra e seus produtos" (FOUCAULT, 2015, p. 291), e no neoliberalismo, em especial no século XX, somando-se ao poder disciplinar, é possível perceber também um segundo polo do biopoder, centrando-se mais no corpo-espécie, “[...] no corpo transpassado pela mecânica do ser vivo e como suporte dos processos biológicos" (FOUCAULT, 2014, p. 150), e, além disso, uma governamentalidade que articula uma fusão entre o homo oeconomicus e a teoria do capital humano, hoje, em certa medida, esse biopoder parece estar sendo rearticulado.

O ponto central dessa reorganização - que é alimentado pelo desenvolvimento de saberes moleculares, como a genômica e a neurociência, além da instituição de uma "política da vida em si mesma" (ROSE, 2013, p. 16) - está inscrito, pelo menos é o que nos indicam algumas $^{108}$ leituras, em uma racionalidade governamental que tende a ser colocada em prática por meio de um controle minucioso não apenas da anatomia "dura" e fechada dos corpos, mas de uma neuroanatomia "sutil" e aberta dos fenômenos mentais ${ }^{109}$. O objetivo indica ser o de promover um governo da vida desde o interior ${ }^{110}$ de nossa "caixa-preta", isto é, complementar o poder sobre a vida (bios) com um poder que atue também sobre o pensamento, a memória, a atenção, sobre os humores, a aprendizagem, a inteligência, enfim, sobre tudo aquilo que esteve, principalmente na modernidade, confinado em nossa interioridade psicológica, e,

\footnotetext{
${ }^{107}$ O liberalismo é entendido por Foucault (2008b) não como uma teoria econômica ou jurídica, nem como uma ideologia, mas como uma prática refletida de governo.

${ }^{108}$ Nicolas Rose (2013) e Francisco Ortega (2008a, 2008b, 2009a, 2009b).

${ }_{109}$ Os fenômenos mentais, aqui, podem ser compreendidos como propriedades que emergem das relações neurofisiológicas e, portanto, da própria corporeidade. De outro modo, os fenômenos mentais, seguindo um dos discursos neurocientífico, correspondem a epifenômenos cerebrais. Com isso, não pretendemos enfatizar o problema mente/corpo.

${ }^{110}$ Falando sobre o pensamento de Michel Hart, Pelbart (2000) relata que o neocapitalismo abomina o dentro e o fora, ele é inclusivo e prospera incorporando em sua esfera efetivos cada vez maiores e domínios da vida cada vez mais variados.
} 
dessa forma, fazer com que não apenas o corpo-máquina constitua capital, mas que a máquina intelectiva também possa fazer isso.

A questão é que, enquanto a psicologia em boa parte do século $\mathrm{XX}$ foi uma das principais ferramentas no gerenciamento de nossos selves ao "proporcionar uma diversidade de maneiras de tornar problemas sociopolíticos inteligíveis e tornar possíveis programas para intervir neles" (ROSE, 2010, p. 312), hoje essa forma de conhecimento parece estar sendo complementada, ou mesmo suplantada, por maneiras neurobiológicas de pensar, " $\mathrm{E}$ certamente podemos ver empreendedores - tanto morais quanto financeiros - querendo encorajar isso" (ROSE, 2010, p. 312). Daí o aparecimento de vários "neurossaberes": neurobiologia, neurociências cognitivas, neuropsicologia (FIORE, 2008), e, ainda, neuroteologia, neurodireito, neurofilosofia, neuroeducação, neuroética, além dos polêmicos neuromitos $^{111}$ e do próprio sujeito cerebral (ORTEGA; ZORZANELLI, 2010). De algum modo, os mecanismos de governo da vida, apoiados nas formas neurobiológicas de pensar, ficaram mais refinados, fala-se, por exemplo, em "governar pelo cérebro" (ROSE, 2010), em aumentar o desempenho dos indivíduos recorrendo a investimento neuroquímico (CRARY, 2016) e/ou a práticas de si cerebrais, ou neuroasceses (ORTEGA, 2009b).

No limiar desse cenário, vemos que a própria noção de corporeidade passa por transformações: "Entregue às novas cadências da tecnociência, o corpo humano parece ter perdido a sua definição clássica e a sua solidez analógica: inserido na esteira digital, ele se torna permeável, projetável, programável” (SIBILIA, 2002, p. 18). Com isso, o biopoder é ampliado, estendendo-se também para além da mecânica "analógica" dos corpos, e, graças ao desenvolvimento das neurociências, para o "sistema operacional" 112 dos seres humanos, chegando à res cogitans.

[...] poderíamos definir, à falta de melhor opção, as novas relações de poder que têm como objeto a memória e seu conatus (a atenção) como noopolítica. A noopolítica (conjunto das técnicas de controle) se exerce sobre o cérebro, atuando em primeiro lugar sobre a atenção para controlar a memória e sua potência virtual. [...] se as disciplinas moldavam os corpos ao construir hábitos na memória corporal, as sociedades de controle modulam os cérebros [...]. (LAZZARATO, 2006, p. 86).

\footnotetext{
${ }^{111}$ Segundo Ortega e Zorzanelli (2010), os neuromitos são construídos quando a citação de um estudo científico cuidadoso extrai um significado que ultrapassa aquilo que se poderia inferir, realizando transposições simplificadoras ou ampliando a capacidade de dedução do achado científico.

${ }^{112}$ Com essa comparação entre analógico e digital não pretendemos reforçar o problema mente/corpo. Trata-se, de certa forma, de afirmar que o poder sobre a vida estendeu-se para o que se acredita ser o "sistema operacional" da identidade do sujeito, isto é, seu código genético e seus circuitos neuronais.
} 
Nessa direção, o que parece interessar a uma política atual da vitalidade não é apenas a disciplina individual dos corpos - entendendo-os em sua macroestrutura -, nem a regulação do corpo social (somente), mas a inclusão de um governo que possa dirigir também, pelo cérebro, os detalhes da vida afetiva e intelectiva (nô̂s). Em outros termos, o biopoder está sendo recoberto por um noopoder e a biopolítica por uma noopolítica, e entre os investimentos em capital humano - os que possuem o potencial de ser mais produtivos destacam-se, contemporaneamente, os noûs investimentos, isto é, empreendimentos que prometem corrigir, potencializar e remodelar, por meio de interferências cerebrais, as nossas características afetivas e cognitivas, as quais passam a ser requeridas no contexto de um capitalismo empresarial ${ }^{113}$.

No entanto, para não oferecer impressões de dualismo, cabe esclarecer que essas características "sutis", noûs, que vêm sendo tomadas pelo biopoder não são estranhas ao corpo. De maneira geral, corroboram a visão científica atual de que o mundo consiste inteiramente de partículas físicas dentro de campos de força - sem negar, no entanto, que entre as características físicas do mundo há fenômenos biológicos, como os estados internos qualitativos (SEARLE, 1997).

Assim, as sociedades economicamente ricas são as que mais promovem esses noûs -investimentos -, uma vez que dispõem de tecnologias de ponta, de recurso financeiro, laboratórios, trabalhos de marketing, concorrência e capital humano. São elas "que melhor desenvolvem esse misto de conhecimento e relação, informação e conexão, intercâmbio vital e educação dos cérebros - e esse parece ser hoje o capital mais promissor" (PELBART, 2000, p. 36). Alguns investimentos têm sido feitos também nos países em desenvolvimento. Atualmente, a performance profissional/cognitiva é considerada no mundo Ocidental a principal fonte de reconhecimento social, o que justifica o grande esforço dos indivíduos, mesmo em países pobres, em superar e otimizar os seus si mesmos (BARROS; ORTEGA, 2011). No Brasil, por exemplo ${ }^{114}$, entre os anos de 2012 e 2017, o mercado de franquias de uma rede de "educação" voltada exclusivamente para a ginástica cerebral, ainda que em

\footnotetext{
${ }^{113}$ Em reportagem do jornal $O$ Globo, na seção Economia, encontramos algumas sugestões sobre as qualidades que um candidato à vaga de trabalho deve ter para "cativar as empresas", são elas: liderança, resiliência (capacidade de encarar os obstáculos com otimismo), sinceridade, competitividade (adequação ao modelo do esporte-aventura), controle (capacidade de manipular o próprio estresse), espírito amigável, ambição (insatisfação diante do presente), capacidade de adaptação, criatividade, competência, paixão (quem não tem paixão, segundo a reportagem, não usa toda capacidade de inteligência), confiança e poder de decisão (rapidez e eficiência nas escolhas). Disponível em: https://oglobo.globo.com/economia/emprego/13-qualidades-doprofissional-que-cativa-as-empresas-12222315. Acesso em: 15 maio 2018.

${ }_{114}$ Disponível em: http://www.franquiaeducacional.com/franquias-premiadas-supera-aumenta-10-vezesfaturamento-rede/. Acesso em: 15 maio 2018.
} 
período de crise econômica, aumentou em dez vezes o seu faturamento, testemunhando, em parte, um crescimento na procura pelo melhoramento da performance dos indivíduos e, ao mesmo tempo, uma adequação cognitiva à lógica contemporânea do mercado.

Ainda no Brasil, segundo Trigueiro (2017), houve um aumento expressivo no uso de medicamentos com o objetivo de aprimoramento ${ }^{115}$ cognitivo, principalmente entre estudantes, empresários e profissionais da área da saúde, mas também entre outros profissionais, dos quais são exigidos atenção, memória, vigília, capacidade de decisão, criatividade, controle emocional e inteligência. Essas exigências, diferentemente do capitalismo industrial, fazem parte de uma era empresarial em que não basta saber apertar um parafuso, "O capitalismo não tolera mais sujeitos burros, nem apáticos, nem isolados, [...] cada vez se requer mais a subjetividade de quem trabalha, sua personalidade, mobilidade, autonomia, decisão, comunicação, coordenação, capacidade de administração da própria atividade e dos outros" (PELBART, 2000, p. 37). Assim, a "alma" do indivíduo, ao ser "localizada" no órgão cerebral, é que acaba por entrar no jogo econômico e na lógica da produtividade, mas não como uma substância etérea, ela agora pode ser lida, interpretada e manipulada no corpo.

Se no filme de Chaplin, Tempos modernos, o indivíduo é confundido com as próprias engrenagens da fábrica, representado como uma peça qualquer, uma alavanca a mais no mecanismo de produção - ou simplesmente um hardware -, hoje a exigência que a lógica neoliberal lhe faz é outra: ela requer suas qualidades mais sutis, sua flexibilidade maquínica e tudo aquilo que pode ser programado, modelado e remodelado, isto é, o seu noûs, a sua alma, o seu sistema operacional, o seu software. Rigorosamente, "é essa parte mais subjetiva, produto da cooperação entre cérebros, a mais estritamente necessária a uma produção qualquer" (LAZZARATO, 2003, p. 77). Com isso, as pessoas são incentivadas, "sob os auspícios de um ethos aventureiro" (EHRENBERG, 2010, p. 33), a usar todos os recursos disponíveis para incrementar os seus si mesmos, incluindo medicamentos, ginásticas cerebrais e autoajuda cerebral.

Em meio a essa conjuntura, novas expertises emergem, então constituídas pelos "peritos da vida em si mesma" (ROSE, 2013), os quais empreendem um novo poder pastoral. Legislam sobre normalidade ${ }^{116}$ e anormalidade, definem o que é saúde e o que é doença, o que

\footnotetext{
${ }^{115}$ De acordo com Trigueiro (2017), o aprimoramento cognitivo farmacológico também é chamado de doping intelectual, neuroaprimoramento farmacológico, aperfeiçoamento cognitivo, uso instrumental de remédios, drogas para "turbinar" o cérebro, ampliadores cognitivos, drogas nootrópicas, neurologia cosmética, Viagra para o cérebro, droga de estudo, pílula da boa nota etc.

${ }_{116}$ Nesse contexto de legislação da normalidade, temos, por exemplo, o trabalho de formulação do DSM-5. Considerado uma espécie de "bíblia da psiquiatria", o Diagnostic and Statistical Manual of Mental Disorders
} 
é saudável e o que não é, ditam o que é bom e o que é ruim elaborando formas inéditas de condução dos comportamentos humanos. Muitos desses peritos carregam consigo o prefixo "neuro", são noûs especialistas. Exemplo disso pode ser encontrado no ambiente educacional, em que cotidianamente um número bastante elevado de crianças é medicado com a justificativa de se combater os comportamentos e humores indesejados, os quais teriam como causa principal certas disfunções cerebrais. Aqueles que já foram os principais responsáveis por exercer uma disciplina sobre a anatomia dos corpos infantis e regular parte do comportamento social, os pedagogos, agora estão cedendo espaço ou simplesmente se filiando aos conselhos dos especialistas em psiquiatria e neuroanatomia dos fenômenos mentais.

Notamos, assim, que há um processo em curso de medicalização da educação (MOYSÉS; COLLARES, 2013). As correções do "desvio" comportamental, por exemplo, estão sendo deslocadas de uma atuação sobre o corpo visível para a administração supervisionada de pílulas ${ }^{117}$ que atuam na microestrutura celular dos humores e da inteligência infantil. E, exagerando um pouco sobre as consequências de tudo isso,

\begin{abstract}
Menino Maluquinho não existe mais, está rotulado e recebendo psicotrópicos para TDAH; Mafalda está tratada e seu Transtorno Opositor Desafiante (TOD) foi silenciado; Xaveco não vive mais nas nuvens, aterrissou desde que seu Déficit de Atenção foi identificado; Emília, tão verborrágica e impulsiva está calada e quimicamente contida; Cebolinha está em treinamento na mesma cabine e nas mesmas tarefas usadas para rotulá-lo como portador de distúrbio de Processamento Auditivo Central (DPAC) e assim está em tratamento profilático da dislexia que terá, com certeza, quando ingressar na escola; Cascão é objeto de grandes debates no comitê que está elaborando o novo DSM-V, com divergências se ele sofreria de TOCS (Transtorno Obsessivo Compulsivo por Sujeira) ou TFH (Transtorno de Fobia Hídrica), mas tudo indica que chegarão a um acordo e os dois novos transtornos recém-inventados serão lançados no mercado, pois quanto mais transtorno melhor. (MOYSÉS; COLLARES, 2013, p. 44).
\end{abstract}

Apesar do exagero e do tom jocoso da citação, a realidade é que toda criança ou adolescente que apresente modos de aprender, de agir e reagir, de se comportar e de não se comportar, que extrapolem aquilo que é considerado padrão corre o risco de ser rotulado como portador de algum transtorno neuroquímico que demanda longos e caros tratamentos, sendo submetidos a vários profissionais e drogas psicoativas (MOYSÉS; COLLARES, 2013).

(DSM) é um manual de diagnóstico produzido pela Associação Americana de Psiquiatria para definir como classificar o diagnóstico de transtornos mentais.

${ }^{117}$ O Brasil tornou-se, em 2010, o segundo mercado mundial de metilfenidato, consumindo algo em torno de dois milhões de caixas por ano. Dados do Instituto de Medicina Social da Universidade do Estado do Rio de Janeiro (UERJ) apontam, ainda, que houve um aumento de 775\% na venda desse fármaco entre os anos 2006 e 2016. 
Assim, a despeito dos novos peritos da vida e do fato de o cérebro ser hoje um ponto de referência para dizer quem é normal e quem é patológico, a questão é que a propriedade da cerebralidade, ou a qualidade de ser e não apenas de ter um cérebro (ORTEGA; VIDAL, 2007), vem tornando-se a principal manifestação da verdade sobre a subjetividade contemporânea. Está presente nas novas maneiras de falarmos de nós mesmos, de descrevermos nossas experiências e condutas, nas novas estratégias de governo da vida, nas novas formas de investimento e nos modos de potencialização da produtividade capitalista. Em certo sentido, a cerebralidade vem sendo um dispositivo, ou marcador somático, extremamente sutil dentro da racionalidade governamental neoliberal. Por meio da cerebralidade é que se busca, contemporaneamente, fortalecer a forma-empresa.

Então o problema biopolítico que se coloca em paralelo com a correção dos humores e da cognição e que consideramos polêmico no momento - principalmente por estar disseminado no discurso cotidiano e associado a práticas de individuação ou subjetivação - é o do aprimoramento cerebral: como podemos aprender mais em menos tempo, melhorar a atenção e a memória, ficar mais tempo em estado de vigília sem prejuízos da capacidade de decisão e humor, alcançar as melhores notas, os melhores cargos, a maior produtividade, enfim, como podemos nos tornar, enquanto empresários de nós mesmos, capital humano/mental.

\subsubsection{Aprimoramento farmacológico e capital mental}

Como Foucault (2008b, p. 311) já havia destacado, no neoliberalismo encontramos uma teoria do homo oeconomicus atrelada à ideia do sujeito enquanto um autoempreendedor, "sendo para si mesmo seu capital, sendo para si mesmo seu produtor, sendo para si mesmo a fonte de sua renda". Essa racionalidade, que contrasta com o liberalismo clássico, acabou por colocar o conjunto de todos os fatores físicos e psicológicos do ser humano na balança de um cálculo econômico, político e científico: “A aptidão a trabalhar, a competência, o poder fazer alguma coisa, tudo isso não pode ser separado de quem é competente e pode fazer essa coisa" (FOUCAULT, 2008b, p. 308). O trabalhador foi convertido, então, em uma espécie de máquina que produz fluxos de renda. Máquina constituída pelo trabalhador e sua competência. A questão é que, com o desenvolvimento dos saberes neurocientíficos e o fortalecimento de uma representação cerebralista de personalidade e subjetividade, o aumento da competência máquina, ou a produção contemporânea de capital humano, começou a ser 
associado - seja por pesquisas cientificamente fundamentadas ou por práticas que se identificam com o discurso da autoajuda cerebral - a uma outra frente de investimentos, a do aprimoramento das performances profissionais/cognitivas.

De certo modo, a compreensão de partes de nossa estrutura cerebral pelas neurociências, em especial as descobertas sobre a plasticidade cerebral ${ }^{118}$, suscitou não apenas o tratamento de patologias, mas investimentos, discursos e práticas que intencionam potencializar as capacidades mentais e maximizar a produtividade capitalista (ORTEGA, 2009a). Assim, desde a atuação sobre a memória e a atenção, passando pelos processos de aprendizagem, tomada de decisão, até o controle do sono e dos humores, foram pontos incorporados pela agenda atual do biopoder. Trata-se, de maneira geral, da produção de "bons equipamentos" cognitivos (FOUCAULT, 2008b, p. 313).

Entre as modalidades de aprimoramento discutidas atualmente, não sem provocar polêmicas, destaca-se, inicialmente, a farmacológica. No Brasil, o tema é bastante novo ${ }^{119} \mathrm{e}$ vem sendo tratado como "neuroaprimoramento cognitivo", "doping cerebral", "neurologia cosmética", e fala-se ainda em "pílulas da inteligência", "drogas para turbinar o cérebro", "uso instrumental de remédios" etc. (BARROS; ORTEGA, 2011; BARROS, 2009; BRANT; CARVALHO, 2012; TRIGUEIRO, 2017; FURTADO, 2017). Apesar de algumas substâncias químicas já serem largamente usadas - do "rebite" de uso do caminhoneiro para se manter acordado até a cocaína aspirada pelo executivo do mercado financeiro, podendo ser acrescentadas também outras substâncias, tais como cafeína, álcool, guaraná, anfetaminas, entre outras -, a novidade está no uso, feito por pessoas saudáveis, de psicoestimulantes que incialmente foram desenvolvidos pela indústria farmacêutica para o tratamento de transtornos de comportamento e personalidade, como narcolepsia, TDAH, doença de Alzheimer e mal de Parkinson.

Segundo Caldwell e Caldwell (2004), por exemplo, a Força Militar dos Estados Unidos já estaria sustentando há algum tempo a ideia de que o "bem comum" justificaria o uso de fármacos para melhorar o desempenho de seus soldados. Considerando que as condições de trabalho em uma operação militar são bastante extenuantes, podendo exigir até mesmo as horas de sono dos militares, e, em consequência, provocando prejuízos na tomada

\footnotetext{
${ }^{118}$ Segundo Ortega (2009a), tornou-se um dado empírico que a estrutura e o funcionamento do cérebro podem modificar-se até idade bem avançada e novos neurônios são criados. É na base desse conhecimento empírico que, por exemplo, tem acontecido um "boom" de práticas neuroascéticas nas últimas décadas, que deram lugar a um florescente mercado de neurobusiness em constante expansão.

${ }^{119}$ Como atesta Barros (2009, p. 10), “A investigação bibliográfica no Brasil indica que não existem textos sobre aprimoramento neurocognitivo farmacológico em revistas científicas". No entanto, o tema vem sendo abordado, segundo a mesma fonte, desde 1997, em revistas e jornais voltados para o público em geral.
} 
de decisões, também colocando em risco operações de guerra, o uso de fármacos seria uma boa opção para atenuar a fadiga, assegurar o melhor desempenho cognitivo e a segurança das operações. Corroborando o que Crary (2016) antes afirmara, isto é, que as inovações relacionadas à guerra geralmente são assimiladas na esfera social, o argumento do uso de fármacos em nome do bem comum defendido pelos militares poderia facilmente ser estendido para outros profissionais, como bombeiros, policiais, médicos plantonistas, cirurgiões, professores com carga excessiva de trabalho, estudantes em véspera de avaliação e também para todos aqueles que foram absorvidos pela lógica da "política da vida em si mesma" (ROSE, 2013, p. 16).

Entre os medicamentos usados com a finalidade de aprimoramento estão o cloridrato de metilfenidato, estimulante do sistema nervoso central com estrutura semelhante à anfetamina, comercialmente vendidos no Brasil como Ritalina, Concerta, Adderall e, ainda, Modafinil (BARROS, 2009). A Ritalina, a exemplo, o estimulante mais popular, é um medicamento cujo "mecanismo de ação no homem ainda não foi completamente elucidado"120 (RITALINA, 2008), mas que se vem mostrando "eficaz" - segundo a opinião de usuários ${ }^{121} \mathrm{e}$ também de alguns especialistas (GREELY, H. et al., 2008) - no aumento do desempenho de funções executivas (tomada de decisões) que exigem boa performance cognitiva. $\mathrm{O}$ seu uso, dizem alguns especialistas, resulta "em maior capacidade de aprendizagem e desempenho intelectual" (FURTADO, 2017, p. 239). No entanto, e a despeito de existir uma grande diversidade de práticas discursivas estimulando sua ministração (BRANT e CARVALHO, 2012), a própria bula alerta sobre possíveis reações adversas desse fármaco, como nervosismo, insônia, instabilidade emocional, ideação e tentativa de suicídio, mania, desorientação, distúrbios da libido, apatia, comportamentos repetitivos, enxaqueca, dependência, entre outras.

Embora esse medicamento e outros estejam submetidos a determinação que controla sua venda - Convention on Psychotropic Substances, de 1971 (BARROS, 2009) -, o que

\footnotetext{
${ }^{120}$ É interessante que a bula do medicamento revela uma fragilidade ligada ao seu mecanismo de ação, alertando que o efeito comportamental e psíquico em crianças não está claramente estabelecido, apesar de ser bastante recomendado e prescrito. Além disso, afirma que não há evidência conclusiva que demonstre como esses efeitos se relacionam com a condição do sistema nervoso central. Disponível em: http://www.bulas.med.br/p/bulas-demedicamentos/bula/3721/ritalina.htm. Acesso em: 28 maio 2018.

${ }^{121}$ Em artigo da revista Superinteressante, intitulada "Pílula para a inteligência", de 2011, há alguns relatos que testemunham o uso da Ritalina: 1. "Eu tinha que me preparar para um trabalho e resolvi tomar um comprimido. O resultado foi incrível, consegui estudar por 12 horas sem parar"; 2. "Era uma época agitada na minha vida. Eu fazia faculdade de direito, trabalhava num escritório e ainda estudava para concursos públicos. Comecei a usar um remédio que o neurologista havia receitado para a minha tia. Não tive nenhum efeito colateral e senti um belo aumento na minha concentração. Na época das provas eu aumentava a dose". Disponível em: https://super.abril.com.br/ciencia/a-pilula-da-inteligencia/. Acesso em: 1 jul. 2018.
} 
regula sua comercialização mediante a apresentação de receita médica para o tratamento da saúde, muitos defendem que eles devam ser usados para outras finalidades, como no aumento do desempenho escolar e na melhoria da performance profissional. Entre as manifestações de defesa e incentivo ao uso desses medicamentos, encontramos, datado de 2009, em artigo da revista Nature, "Towards responsible use of cognitive-enhancing drugs by the healthy" escrito por pesquisadores de universidades americanas e britânicas: Henry Greely, Philip Campbell, Barbara Sahakian, John Harris, Ronald C. Kessler, Michael Gazzaniga e Martha Farah -, a reivindicação de regulação e liberação dessas drogas, mediante a realização de pesquisas adequadas, para pessoas que são saudáveis e desejem melhorar e potencializar os seus si mesmos. Esses autores, de maneira geral, defendem que toda a sociedade deveria aceitar os benefícios que o aprimoramento farmacológico pode oferecer, pois, segundo eles, a medicalização é apenas mais um elemento potencializador de características cognitivas que pode ser somado à educação, ao trabalho e aos bons hábitos de saúde.

Como todas as novas tecnologias, o aprimoramento cognitivo pode ser bem utilizado ou não. Devemos acolher os novos métodos de aprimoramento das funções cerebrais. Em um mundo onde áreas de trabalho e a expectativa de vida estão aumentando, as ferramentas de aprimoramento cognitivo incluindo as farmacológicas - serão cada vez mais úteis para melhorar a qualidade de vida e aumentar a produtividade do trabalho, mas podem ser usadas também para evitar o declínio cognitivo normalmente causado pelo avanço da idade ou por patologias. O melhoramento cognitivo seguro e eficaz beneficiará tanto o indivíduo quanto a sociedade ${ }^{123}$. (GREELY et al. 2008, p. 705, tradução nossa).

Ao sugerir e defender o uso de fármacos que atuem sobre o cérebro potencializando a produtividade do trabalho, o artigo da Nature, mesmo que indiretamente, faz alusão à possibilidade de melhoramento do capital humano e expressa um conformismo com a lógica neoliberal descrita por Foucault (2008b, p. 313), em que as boas qualidades cognitivas, na mesma linha dos bons equipamentos genéticos, vão se tornar uma "coisa rara, e na medida em

\footnotetext{
122 "Em direção ao uso responsável de drogas para o aprimoramento cognitivo de pessoas saudáveis". (Tradução nossa). Disponível em: https://repository.upenn.edu/cgi/viewcontent.cgi?article=1039\&context=neuroethics_pubs. Acesso em: 28 maio 2018.

${ }_{123}$ "Like all new technologies, cognitive enhancement can be used well or poorly. We should welcome new methods of improving our brain function. In a world in which human workspans and lifespans are increasing, cognitive enhancement tools - including the pharmacological - will be increasingly useful for improved quality of life and extended work productivity, as well as to stave off normal and pathological agerelated cognitive declines [Beddington, J. et al. Nature, n. 455, p. 1.057-1.060, 2008] $]^{23}$. Safe and effective cognitive enhancers will benefit both the individual and society". Disponível em: https://repository.upenn.edu/cgi/viewcontent.cgi?article=1039\&context=neuroethics_pubs. Acesso em: 28 maio 2018.
} 
que será uma coisa rara poderão perfeitamente (entrar), e será perfeitamente normal que entrem, em circuitos ou em cálculos econômicos, isto é, em opções alternativas". Desse modo, há uma clara indicação, ou até mesmo pressão, para que as pessoas, cuja personalidade e subjetividade são agora representadas pela neuroquímica cerebral, se adaptem às novas exigências morais e sociais de uma realidade que valoriza a ótima performance individual e o trabalho produtivo. E, seguindo o mesmo raciocínio,

\begin{abstract}
Se novas drogas como o modafinil ou metilfenidato, ou técnicas para edição genômica, ou ainda próteses cerebrais e dispositivos tDCS [estimulação transcraniana de corrente contínua] se tornarem realmente eficazes e seguros para fins terapêuticos no futuro, não há razão alguma para supormos que eles não deveriam jamais ser usados para fins de aprimoramento cognitivo também. Esses "novos procedimentos" podem vir a nos ajudar a viver em ambientes que, provavelmente, serão ainda mais exigentes em termos cognitivos do que os ambientes em que vivemos atualmente. (ARAÚJO, 2017, p. 10).
\end{abstract}

É claro que cabem aqui algumas indagações: Como o melhoramento cognitivo está sendo exigido, em quais situações e por quem? E, se os métodos de aprimoramento farmacológicos das funções intelectivas já vêm sendo utilizados (BUTCHER, 2003 ${ }^{124}$ ), por que então ainda são tratados como peças em um jogo de ficção científica? A despeito dessas possíveis questões, podemos observar que a lógica que se faz presente é a da governamentalidade neoliberal, isto é, o que interessa é a produção de "opções alternativas", ou, simplesmente, a constituição de capital mental. Assim, como indicamos, o capital passou a situar-se não na força bruta da anatomia dos corpos, como no início do período industrial, mas nos processos sutis da cognição, na bioquímica cerebral: "não temos mais a sociedadefábrica industrial, mas a empresa-sociedade. A substância do valor situa-se na sociedade, na população, nos saberes implícitos, nos processos cognitivos, na cooperação social" (MOULIER-BOUTANG, 2003, p. 41).

A potencialização da atenção, da memória, da volição, o controle do humor etc., vem constituindo, no contexto de "uma forma de vida emergente" (ROSE, 2013, p. 121), uma opção estratégica para o aumento da produtividade empresarial. E soma-se a isso a busca de reconhecimento social pelo sujeito, o seu desejo de visibilidade, o qual é movido pela lógica da competitividade, pelo culto da performance (EHRENBERG, 2010) e pelo ideal do autoempresariamento. Ademais, o aprimoramento cognitivo vem acontecendo "mediante a

${ }^{124}$ Disponível em: http://neuroethics.stanford.edu/documents/Neuroethics_Lancet_feature.pdf. Acesso em: 1 jun. 2018. 
prescrição ${ }^{125}$ de um profisssional do campo da saúde, em atendimento à demanda de um sujeito, individual ou coletivo, inseridos no campo da educação e/ou do trabalho, e em resposta aos imperativos de uma economia e de um mundo extremamente competitivo e globalizado" (BRANT; CARVALHO, 2012, p. 625).

Ao fazer um levantamento sobre pesquisas que apontam para o uso do metilfenidato por pessoas saudáveis entre os anos de 2006 e 2016 - especialmente com a finalidade de melhorar a capacidade cognitiva no campo da educação -, Trigueiro (2017) chegou às seguintes informações: há uma prevalência de uso entre universitários de 1,9\% em Portugal (GRAÇA, 2013 apud TRIGUEIRO, 2017), 24,5\% nos Estados Unidos (TETER et al., 2006 apud TRIGUEIRO, 2017) e 35\% na Colômbia (BARON et al., 2011 apud TRIGUEIRO, 2017). Entre estudantes secundaristas americanos o uso foi de 4\% (LIAKONI, et al., 2015 apud TRIGUEIRO, 2017). Já entre cientistas de 60 países, o uso chegou a 20\% (MAHER, 2008 apud TRIGUEIRO, 2017). Trigueiro (2017) observa também que em países como Alemanha, Japão e Austrália, por exemplo, a prática não é muito comum, sendo considerada até mesmo imoral. Já, no Brasil, em meio às universidades públicas e privadas das 27 capitais brasileiras, aponta-se um uso que varia de $6 \%$ entre estudantes do Distrito Federal (AFFONSO et al., 2016 apud TRIGUEIRO, 2017), até 60\% entre estudantes de uma universidade do Rio de Janeiro (MOTA; PESSANHA, 2014 apud TRIGUEIRO, 2017). Em relação ao público secundarista do Brasil, foi constatado, por exemplo, que $15 \%$ dos estudantes de cursos pré-vestibulares de Belo Horizonte (MG) faziam uso do cloridrato de metilfenidato (CASSEMIRO, 2012 apud TRIGUEIRO, 2017). De certo modo, essas informações mostram que a busca pela potencialização cognitiva, principalmente por meio de fármacos, já não se restringe a um assunto de ficção científica, é uma realidade atual.

Algumas preocupações a respeito do neuroaprimoramento farmacológico, no entanto, têm sido colocadas principalmente no que tange aos temas de segurança, liberdade e igualdade de acesso (GREELY et al., 2008). O primeiro tema versa sobre as consequências em longo prazo do uso desse tipo de medicamento por pessoas que são saudáveis - já que o cérebro é um órgão bastante complexo. Trata-se, principalmente, de uma preocupação com os efeitos colaterais, com as possíveis sequelas e com a avaliação dos riscos e benefícios do seu uso.

\footnotetext{
${ }^{125}$ Segundo Barros (2009), a venda do cloridrato de metilfenidato, apesar de ser legitimamente controlada, também é feita ilegalmente no mercado negro (sendo possível ser comprada até mesmo pela internet). Além disso, a autora verificou que estudantes que fazem uso de metilfenidato para aprimoramento cognitivo usam a estratégia de adquirir o medicamento por intermédio de estudantes colegas que têm legítimas prescrições.
} 
Sobre a liberdade de escolha, esta vem sendo contrastada com o perigo da coação, isto é, em uma sociedade competitiva torna-se muito difícil conseguir preservar o direito de não usar o medicamento. Teixeira (2007), por exemplo, relata que, se o aperfeiçoamento farmacológico das capacidades cognitivas se difundirem, as pessoas poderão sentir-se pressionadas a se submeterem: "A pressão poderá ser explícita - por empregadores interessados em mais produtividade", ou mais sutil: "se seu colega de classe usa estimuladores das funções cognitivas e você não, quem vai obter melhores notas e, possivelmente, encontrar as melhores posições disponíveis no mercado de trabalho?" (TEIXEIRA, 2007, p. 501). Além disso, existe outro problema que parece bastante perigoso, a saber: diante de pais desejosos de verem o sucesso dos filhos, ávidos por presenciar suas melhores performances escolares, há o risco de que eles lhes ofereçam drogas aperfeiçoadoras (BUTCHER, 2003).

O tema da igualdade de acesso, ou o problema da "justiça social" (BARROS; ORTEGA, 2011), refere-se ao fato de que os produtos farmacológicos de melhoramento cognitivo, como as demais mercadorias do mundo capitalista, não são acessíveis a todos, uma vez que sua venda e consumo envolvem fortes interesses econômicos, ou bioeconômicos, o que poderia intensificar ainda mais a desigualdade social. Pensando nisso, Araújo (2017, p. 8) sugere que o Estado deveria ter a obrigação de promover o aperfeiçoamento cognitivo artificial de seus cidadãos, afirmando: “A meu ver, não há nenhuma razão para rejeitarmos de antemão a promoção do aprimoramento cognitivo como uma questão de saúde pública”. Será, então, que caminhamos em direção a um futuro em que o próprio Estado, associado a empresas farmacêuticas, se prontificará a aprimorar o capital mental de deus cidadãos, ou para uma situação em que as empresas, ao buscarem o aumento da produtividade, irão, elas mesmas, oferecer intensificadores da cognição (como já parece ocorrer no ambiente militar) ${ }^{126}$ ?

Além dessas preocupações, há também outros questionamentos mais pontuais (GREELY et al., 2008), a saber: Se a conquista de um objetivo foi facilitada ou intermediada por uma droga, qual o seu valor? Potencializar a concentração com o uso de fármacos não é o mesmo que medicalizar a atenção e, assim, patologizar a desatenção? Se uma pílula puder mudar a capacidade de aprender ou permitir maior retenção de lembranças, de que modo a identidade poderá ser afetada? E, ainda, se lembrar é um assunto neuroquímico, esquecer

\footnotetext{
${ }^{126}$ Segundo alguns relatos, como os que constam no jornal londrino The Guardian e no americano Washington Post, países do Reino Unido e Estados Unidos estariam, desde a década de 1990, oferendo uma variedade de medicamentos a seus soldados com a finalidade de mantê-los acordados (até 85 horas), atentos e ativos.
} 
também. Haverá uma demanda pelo esquecimento artificial? Será possível fazer com que as pessoas esqueçam suas tragédias pessoais? Ao comparar o doping cerebral com o esportivo, há quem o problematize ainda como uma fraude ou forma desonesta de sobressair-se, então, diante disso, algumas pessoas se perguntam: “Chegará o dia em que se pedirá aos estudantes que tenham em mãos uma amostra de urina, para ser entregue com as avaliações escolares, para comprovar que seus resultados são esforços de trabalho duro e não farmacológico? ${ }^{127}$ ” (BUTCHER, 2003, p. 132, tradução nossa).

No tocante a esses questionamentos, alguns debates têm ocorrido no âmbito daquilo que é denominado de neuroética (ROSE, 2013), mas, independentemente dessas e de outras questões, e de suas possíveis respostas, ou não, isso tudo pode ser lido também no registro daquilo que é denominado de uma forma de vida emergente: "Algo de novo que está assumindo vulto como consequência da intersecção de muitas sendas contingentes [...]. Algo novo que está surgindo do entretecimento de formas de pensar e de agir em uma série de práticas médicas, legais, econômicas, políticas, éticas” (ROSE, 2013, p. 121).

Assim, se os artifícios biomédicos serviam para restaurar certa "normalidade" perdida, hoje eles estão sendo usados para criar outra realidade. A demanda pelo aprimoramento farmacológico, já existente (GREELY et al., 2008; BUTCHER, 2003; TRIGUEIRO, 2017), mostra que as pessoas estão pensando os seus si mesmos neuroquímicos e suas capacidades corporais como sujeitas a todo tipo de modificações, estão abrindo-as ao artifício e incluindo "seu gerenciamento dentro da remessa da biomedicina do tribunal para a clínica e para o mercado" (ROSE, 2013, p. 123).

No horizonte desse acontecimento, a nova categoria de fármacos acaba então por exemplificar o modo neoliberal de agir: por um lado, criando um individualismo essencial, marcado pela máxima de que cada um deve ser um empresário de si mesmo (devendo fazer investimentos em sua própria subjetividade), por outro, desenvolvendo métodos de controle e de governo da vida cada vez mais sofisticados - coagindo os indivíduos de forma aparentemente não violenta. Ao incitar, e mesmo excitar, o potencial cognitivo e afetivo, o capital acaba por agenciar uma fonte aparentemente inesgotável de recursos.

\subsubsection{Ascese cerebral}

Além dos fármacos, outra promessa de potencialização dos processos cognitivos que

\footnotetext{
127 "Will the day come when students are told to hand in a urine sample along with their examination manuscript to prove that their achievements were the result of hard work and not pharmacology?".
} 
se destaca na atualidade, apesar de seus vestígios ${ }^{128}$ remeterem ao século XIX, é a neuroascese ou autoajuda cerebral. Trata-se de discursos e práticas referentes a modos de agir sobre o cérebro e/ou selves objetivando uma maximização das performances (ORTEGA, 2009a). Se nas sociedades antigas, como a grega, a romana e até mesmo a judaico-cristã, as práticas de si, ou ascese (áskesis) - chamadas por Foucault (2006) de estética da existência -, representavam "frequentemente um desafio aos modos de existência prescritos, uma forma de resistência cultural, uma vontade de demarcação, de singularização, de alteridade" (ORTEGA, 2008b, p. 20), constituindo, mediante práticas de abstinência, meditação, meditação sobre a morte, meditação sobre os males futuros, exame de consciência, entre outros, "sujeitos morais" (Antiguidade greco-latina) ou seres "purificados" (cristianismo), hoje as práticas de si cerebrais, a neuroascese, parecem estar submetidas a outro tipo de racionalidade. Houve um deslocamento dos exercícios que o indivíduo tradicionalmente realizava sobre si mesmo (FOUCAULT, 2006) e o télos da ascese: da psykhé para o soma, da interioridade metafísica para o cérebro e da realização espiritual para a conquista econômica.

Ortega (2008b) aborda muito bem esse assunto ao falar sobre a passagem da ascese para a bioascese, e desta última para a neuroascese. Segundo o autor, enquanto as asceses clássicas visavam à transcendência do corpo e ao bem comum, à autossuperação ou ao contato com a divindade, as práticas bioascéticas atuais são "apolíticas e individualistas, faltando nelas a preocupação com o outro e com o bem comum" (ORTEGA, 2008b, p. 47). No “cuidado de si" contemporâneo, a preocupação do sujeito se traduz pela busca da saúde e da perfeição corporal, fundamentando-se na ideia de que o indivíduo é o único responsável por sua existência física, afetiva e econômica. Há uma clara responsabilização do eu (self) e, em paralelo, uma desresponsabilização do Estado e do mercado em relação ao modo de existência das pessoas. Trata-se "da produção desses seres exercitantes e exercitados que, independentemente das condições exteriores, das necessidades econômicas e das dificuldades sociais, podem vencer todos os obstáculos e conquistar todos os seus objetivos" (MARÍNDÍAZ, 2015, p. 72).

Compreendida enquanto ramificação da bioascese, a neuroascese, por sua vez, "se

\footnotetext{
${ }^{128}$ Embora a história da neuroascese ainda esteja por ser escrita, como pontua Ortega (2009a), alguns eventos históricos que comprovam a sua prática podem ser trazidos a lume desde o século XIX. Práticas que antecedem as descobertas de Pierre Paul Broca sobre a assimetria cerebral, como as sugeridas por Arthur Wigan (17851847), que considerava a ideia do cérebro duplo e enfatizava a educação, o autocontrole e os exercícios cerebrais (mudanças de hábitos motores); o ambidestrismo, sugerido, entre outros, por James Liberty Tadd (1854-1917), que enfatizava o exercício dos dois hemisférios cerebrais com o intuito de duplicar as capacidades cognitivas; práticas frenológicas que focalizavam, a exemplo, o tratamento moral, via esquema de divisão mecânica do cérebro, movimentos de self-help e new thought (ORTEGA, 2009a).
} 
insere no contexto do crescente impacto das neurociências e do surgimento do sujeito cerebral" (ORTEGA, 2009a, p. 248). Populariza-se como "prática de si", sendo um produto da interface entre o conhecimento científico e o senso comum. É divulgada amplamente pelos meios de comunicação de massa, bem como alimentada pela ideia de que o cérebro é o principal ator social da contemporaneidade, "“...] jornais e as revistas de divulgação científica, a televisão e o cinema difundem continuamente imagens que insistem na associação entre a mente e o cérebro, sendo a mente localizada no cérebro" (ORTEGA, 2009a, p. 250).

Ao traçar os caminhos genealógicos da ascese cerebral, Ortega (2009a) afirma que desde o século XIX o cérebro vem compondo diferentes significados e possibilidades de interpretação: morais, sociais, econômicas, políticas e teológicas. Nesse período, por exemplo, foram realizados esforços na tentativa de encontrar a inscrição neural da criminalidade, da genialidade e da loucura, o que se estendeu "desde a antropologia física oitocentista defensora dos aspectos neurais para justificar hierarquias e diferenças sociais e raciais - até o escrutínio dos cérebros de Lênin, Einstein [...]" (ORTEGA, 2009a, p. 623). Atualmente, porém, ao enfatizar esse órgão, o autor afirma que os proponentes da neuroascese não estão preocupados em delimitar o self, nem em recuperar uma ordem sociomoral "erodida pela perda da legitimidade da autoridade" (ORTEGA, 2009a, p. 635) - como postulava a ascese cerebral nos séculos anteriores -, mas sim em transformá-lo (o self). O objetivo das "práticas de si" cerebrais envolve, atualmente, a inserção do indivíduo na demanda produtiva do mercado, que busca transformá-lo em um ser eficiente, flexível e adaptável.

Assim, enquanto a meta da ascese clássica era fazer os indivíduos atingirem "um objetivo espiritual definido" (FOUCAULT, 2006, p. 505), entendendo por objetivo espiritual "uma certa mutação, uma certa transfiguração deles mesmos enquanto sujeitos, enquanto sujeitos de ação e enquanto sujeitos de conhecimento verdadeiro", no télos da ascese cerebral estão presentes as marcas da biopolítica contemporânea e do homo oeconomicus - lembrando que para Rose (2013) é nessa biopolítica que surge a percepção de que experimentamos uma “[...] 'mudança de cadência', um crescimento qualitativo em nossas capacidades de manipular nossa vitalidade, nosso desenvolvimento, nosso metabolismo, nossos órgãos e nossos cérebros" (ROSE, 2013, p. 17). Fala-se ${ }^{129}$, assim, em potencializar, por meio de ginásticas cerebrais ou neuróbica, a memória, a criatividade, o foco, o raciocínio lógico, a autoestima, a disciplina, e, ainda, usar as descobertas neurocientíficas "no cotidiano das empresas [...]

\footnotetext{
${ }^{129}$ A potencialização dessas performances, tal como exposto, é o que promete uma empresa brasileira dedicada ao desenvolvimento das capacidades do cérebro e da saúde mental. Disponível em: https://metodosupera.com.br/nossa-empresa/. Acesso em: 20 jun. 2018.
} 
auxiliando no enfrentamento do desafio de levar as pessoas ao máximo de sua potência" $\left(\right.$ TIEPPO, 2017) ${ }^{130}$. E mais:

\begin{abstract}
Nesse contexto vem aparecendo um crescente mercado de (neuro)produtos que incluem: best-sellers de autoajuda cerebral prometendo desenvolver determinadas regiões do cérebro, o que permitiria desde aumentar o desempenho do raciocínio e da memória, combater depressão, ansiedade, adicções e compulsões diversas, até melhorar o desempenho sexual, atingir a felicidade ou estabelecer contato direto com Deus; softwares e programas de fitness cerebral para computador que constituem verdadeiras academias para o cérebro (brain gyms) [...]. (ORTEGA, 2009a, p. 622).
\end{abstract}

Temos que o "poder enformador" da neuroascese, do mesmo modo que a reflexão feita por Foucault (2008b), advém da forma-empresa, isto é, o cuidado de si (que na prática se manifesta como governo de si) - seu método e télos -, reveste-se de uma interpretação no campo da análise econômica. Ao discutir sobre a composição do capital humano (elementos inatos e adquiridos), o autor faz o seguinte questionamento: “Ora, é evidente que não temos que pagar para ter o corpo que temos, ou que não temos de pagar para ter o equipamento genético que é o nosso. Isso tudo não custa nada. Bem, não custa nada - será mesmo?" (FOUCAULT, 2008b, p. 379). Deslocando essa observação da genética, tal como originalmente é apresentada, para uma interpretação neurológica do ser humano, em especial para o contexto da produção contemporânea de capital humano, muitas pessoas acabam por admitir como justo ou simplesmente aceitável custear suas maximizações cognitivas e afetivas. De outro modo, a transformação do self, especialmente sua potencialização, torna-se algo comercializável, algo ofertado no mercado e com certa procura - "treine o seu cérebro, viva essa emoção"'131.

A promessa de mais e melhores aptidões abre espaço para propostas de métodos e exercícios cerebrais que, segundo seus proponentes, garantem o sucesso e a felicidade. Assim, associados a produtos farmacológicos, surgem uma literatura voltada à autoajuda cerebral, empresas de neuróbica, guias de neuroascese, técnicas de "si" cerebrais - tudo isso sob a proteção de marketing em prol do sucesso pessoal, aumento da eficiência empresarial e maximização das performances mentais/cerebrais.

Segundo Ortega (2009b), todas as características da autoajuda tradicional estão presentes na cerebral (autoajuda), mas aparecem sob roupagem cientificista, como a ênfase na

\footnotetext{
${ }^{130}$ Disponível em: http://a4.carlatieppo.com.br/palestras/. Acesso em: 20 jun. 2018.

131 Essa é uma das frases que ecoa na propaganda do método Supera. Disponível em: https://metodosupera.com.br/. Acesso em: 30 jun. 2018.
} 
criatividade que engendra a realidade, "a ideia de um 'eu interior' que pode ser cultivado e promovido pela manipulação cerebral; a insistência na autonomia e autocontrole dos nossos destinos e até da própria realidade, atingidas agora com práticas neuroascéticas" (ORTEGA, 2009 b, p. 253). A ideia de cérebro duplo ${ }^{132}$, por exemplo, e toda uma moda neuroeducativa que insistia nas inúmeras vantagens escolares do treinamento do hemisfério cerebral direito, vem sendo retomada nesses discursos, repudiando o sistema educativo tradicional baseado no hemisfério esquerdo.

Em uma das frentes de investimento, há consultorias empresariais e treinamento cerebral sendo oferecidos, como os trabalhos da neurocientista Carla Tieppo, que podem ser facilmente visualizados em seu site ${ }^{133}$. Em 2016, por exemplo, constava na referida página que a neurocientista estava selecionando um corpo docente que então seria composto de especialistas do cérebro e profissionais de gestão empresarial. O objetivo era fornecer aos funcionários de empresas cursos e treinamento em neurociências e elevar a capacidade de produção a suas "potencialidades máximas".

Há nessas ofertas uma promessa de desenvolver nos "colaboradores" o autoconhecimento, a volição, diminuir o estresse, aumentar a memória, a atenção, entre outras: “[...] se o setor de Recursos Humanos dominar os conhecimentos da neurociência, será muito mais fácil promover um engajamento e eficiência na tomada de decisão por meio de treinamentos diretamente desenvolvidos para promover essas características" (TIEPPO, 2017) ${ }^{134}$. A ideia parece clara: potencializar o capital humano das empresas por meio de investimentos cerebrais e, consequentemente, aumentar a eficiência e a produtividade. Assim, podemos afirmar que o crescimento dos neuronegócios sinaliza uma preocupação em formar, agindo sobre o si mesmo cerebral, "essas espécies de competência-máquina que vão produzir renda" (FOUCAULT, 2008b, p. 315).

Tal postura pode ser corroborada por outra oferta de treinamento cerebral facilmente encontrada na internet, em panfletos distribuídos em semáforos e também na mídia ${ }^{135}$, com repercussão em programas como o Fantástico, da TV Globo, que é o caso da empresa Supera, já mencionada anteriormente. Consta em seu site ${ }^{136}$ oficial que teria sido fundada nos anos de

${ }^{132}$ Época posterior à descoberta da localização da faculdade da linguagem no hemisfério esquerdo do cérebro pelo neurologista francês Pierre Paul Broca. O hemisfério esquerdo era considerado superior, ao ser responsável pelas atividades intelectuais e civilizadas, predominando em homens brancos e europeus. $\mathrm{O}$ direito, em contrapartida, preponderava em mulheres, criminosos, índios, negros, loucos e homossexuais (Harrington, 1987 apud Ortega, 2009b, p. 254).

${ }_{133}$ Disponível em: http://www.ilumne.com.br/neurociencia-e-negocios/. Acesso em: 22 jun. 2018.

${ }^{134}$ Disponível em: http://a4.carlatieppo.com.br/palestras/. Acesso em: 20 jun. 2018.

${ }^{135}$ Entrevistas na televisão (na TV Globo, programa Fantástico, Bem-Estar, TV Brasil etc), Folha de São Paulo, portal da educação (Porvir), etc. 
2006, no Brasil, e atualmente estaria contando com mais de 300 unidades espalhadas por todo o país, com filiais também em Portugal. Além das unidades franqueadas, que prometem atender às demandas "empresariais" de seus clientes, como eficiência e alta produtividade, os cursos de estimulação cognitiva estariam sendo oferecidos também a escolas públicas e particulares no formato de projetos especiais, a exemplo do que estaria acontecendo, segundo informações ${ }^{137}$ do site, em sete escolas municipais de São José dos Campos/SP, no colégio Artur Ferreira, em Santa Isabel/SP, em escolas de Poços de Calda/MG, Lucas do Rio Verde/MT, entre outras - caracterizando um neuronegócio em expansão, com direito a convenções, workshops, encontros nacionais etc. O "SUPERA para a escola", como é chamado, é ofertado na modalidade presencial, envolvendo atividades com jogos individuais e coletivos, cálculos com o uso do ábaco e a resolução de exercícios lógicos, incluindo também o fornecimento de apostilas e o que o programa chama de neuroludoteca. Há, além disso, a modalidade online, que envolve a realização de exercícios e atividades virtuais por meio de softwares de ginástica cerebral ${ }^{138}$. Entre os benefícios que o Supera vem prometendo no âmbito da educação, estão: melhorar a competitividade e os reflexos financeiros, melhorar os indicadores do desempenho do ensino (Índice de Desenvolvimento da Educação Básica IDEB; Exame Nacional do Ensino Médio - ENEM; Sistema de Avaliação do Rendimento Escolar do Estado de São Paulo - SARESP), melhorar a imagem da escola, potencializar a concentração e o foco dos estudantes, aumentar a velocidade de raciocínio, potencializar a capacidade de resolver problemas, melhorar o relacionamento interpessoal, a perseverança, a disciplina, a autoestima, a confiança, e assim por diante.

É interessante observar que, entre os benefícios prometidos, alguns são direcionados também aos "colaboradores" das empresas, notadamente, para que atuem aumentando a produtividade e a eficiência do próprio trabalho. No site do Supera, por exemplo, encontra-se a afirmação de que o ativo atual mais crítico para o desempenho de uma empresa qualquer são as suas pessoas e seu cérebro - sendo pessoas e cérebros claramente considerados como reduzíveis um ao outro. Ainda, menciona que, para as empresas manterem "seus profissionais com elevada capacidade de mudar e aprender, maximizando a utilização da capacidade intelectual" "139, devem recorrer a métodos de treinamento cerebral. Nessa direção, seja no âmbito escolar ou no espaço de trabalho, para o Supera o cérebro apresenta-se como a

\footnotetext{
${ }^{136}$ Disponível em: https://www.superaonline.com.br/quem_somos.php. Acesso em: 30 jun. 2018.

${ }^{137}$ Disponível em: https://superaparaescolas.com.br/. Acesso em: 30 jun. 2018.

${ }^{138}$ Disponível em: https://www.neuronation.com/. Acesso em: 30 jun. 2018.

${ }^{139}$ Disponível em: https://www.superaonline.com.br/para_sua_empresa.php. Acesso em: 1 jul. 2018.
} 
principal referência para as práticas e discursos que envolvem o melhoramento das performances, é o órgão, por excelência, no qual deve acontecer a aventura empreendedora do sujeito sobre si mesmo. Assim, recomenda-se, desde a realização de exercícios físicos, horas de sono, alimentação saudável, praticar jogos como rummikub ${ }^{140}$ e gamão ${ }^{141}$, cálculos com o ábaco até atividades de fitness cerebral por meio de softwares computacionais.

Mesmo que muitas dessas práticas treinem o corpo, como lembra Ortega (2009b), o discurso é de que o cérebro é que está sendo visado. A empresa de ginástica cerebral propaga, desse modo, a ideia de que é por meio do cérebro que o sujeito pode ser transformado, tornando-se mais eficiente e produtivo. Ainda, no mesmo site é dito que o método de ginástica cerebral encontra respaldo em descobertas e conceitos científicos como o de neuroplasticidade e metacognição - na capacidade que o cérebro tem de produzir novas conexões neurais e na tomada de consciência das estratégias que cada um usa para aprender. Coincidentemente, ou não, esses conceitos são os mesmos apontados por Ortega (2009b) ao comentar sobre os fundamentos da neurocultura, autoajuda cerebral e sobre a proliferação dos neuronegócios nos Estados Unidos, particularmente quando comenta sobre a criação da Posit Science Corporation - empresa que afirma ter por objetivo "ajudar as pessoas a prosperar ao longo de suas vidas" (TEITCHER, 2005 apud ORTEGA, 2009b, p. 252). O programa de fitness cerebral da Posit Science estaria concentrado "no aperfeiçoamento da velocidade, precisão e intensidade com as quais nosso cérebro recebe, registra e lembra aquilo que ouvimos" (ORTEGA, 2009b, p. 252), o que coincide também com as propostas de exercício cerebral divulgadas pela empresa brasileira.

Fica evidente nesses (neuro) investimentos, a despeito de uma interpretação reducionista do homem e da eficiência ou não desses métodos, a manifestação de novos elementos dentro da política contemporânea da vida: interesses privados, tecnologias do self, aumento das performances e, é claro, a própria figura do sujeito cerebral. O cérebro, nessa direção, torna-se uma importante referência para o governo atual da vida, uma espécie de marcador somático das políticas de subjetivação. Por meio dele se constituem os selves objetivos, "uma categoria de pessoas desenvolvida mediante conhecimento especializado" (ORTEGA, 2009b, p. 249), além de novos agrupamentos humanos:

- grupos que se reúnem para testar performances intelectuais lançando mão de jogos

\footnotetext{
${ }^{140} \mathrm{O}$ rummikub combina elementos dos jogos de cartas, dominó e xadrez.

${ }^{141}$ É conhecido como um jogo de "percurso": dois jogadores, diante de um tabuleiro, movem suas peças em sentido contrário e, à medida que lançam dados, estes determinam quantas “casas” o jogador deve avançar.
} 
mentais e olimpíadas ${ }^{142}$ de desafios às capacidades cerebrais etc.;

- neurocomunidades que visam discutir os assuntos cerebrais, os jogos que exercitam o cérebro e todo um mercado dirigido a esse público - comércio de livros, camisetas, bonés, canecas, neurocalendários etc.;

- grupos de apoio para portadores de diversos transtornos neurodegenerativos ou síndromes, tais como Alzheimer, esquizofrenia, Parkinson, TDAH etc.;

- movimentos de neurodiversidade ${ }^{143}$, "como grupos de autistas que usam o critério cerebral para reclamar um acesso à cidadania que o modelo biomédico lhes tinha negado" (ORTEGA, 2009b, p. 251).

Porém, em meio a esses quatro agrupamentos destacados por Ortega (2009b), as práticas mercadológicas da neuroasce se aproximariam mais dos dois primeiros grupos:

Obviamente, existe uma diferença do ponto de vista do significado sociopolítico entre grupos de apoio a portadores de doenças e transtornos específicos, grupos pró e anticura, que aparecem no debate em torno do autismo, por um lado, e neurocomunidades de adolescentes, clubes do cérebro e empresários dos neuronegócios, pelo outro. Ambos os grupos têm o cérebro como referência. Todavia, enquanto os primeiros poderiam ser compreendidos como formas de resistência a um tipo de racionalidade política neoliberal aparelhada com tecnologias neurocientíficas, os segundos se enquadram plenamente nos objetivos dessa racionalidade política. (ORTEGA, 2009b, p. 251).

O sujeito cerebral, ou o seu órgão definidor, torna-se, então - movido pelo estilo molecular de pensamento e pela racionalidade neoliberal -, um elemento a mais dentro da política atual da vida. No entanto, essa mesma figura antropológica, por meio da qual o biopoder atua produzindo subjetividades, neuroidentidades, negócios e neuronegócios, traçando novas propostas de governo, disfarçadas, ao que parece, de um cuidado de si enviesadas pelo aumento das performances -, contém também aquilo que alguns pensadores, como Esposito (2017), Pelbart (2007) e outros, chamam de potência da vida. Uma espécie de força capaz de pôr em questão o próprio governo da vida mínima e, ao mesmo tempo, fazer

\footnotetext{
${ }^{142} \mathrm{Na}$ Inglaterra, esses eventos estariam sendo promovidos por escritores de autoajuda cerebral, como Tony Buzan, autor da ideia de mapas mentais (ferramenta que promete liberar o potencial do cérebro) e considerado no ambiente do debate sobre neuroascece uma autoridade em aprendizagem, memória e uso do cérebro. No Brasil, a rede Supera vem promovendo "Olímpiadas de Ábaco". Em 2017 foi realizada décima segunda edição desse evento. Disponível em: https://metodosupera.com.br/alunos-vencedores-12-olimpiada-de-abaco-supera/. Acesso em: 1 ago. 2018.

${ }_{143}$ Uma "cultura autista" vem sendo desenvolvida segundo modelos de pensamento e estilos de vida considerados autistas (ORTEGA, 2009b).
} 
uma reversão desse mínimo.

É nessa direção que Ortega (2009a) indica, principalmente quando afirma que os grupos apoiadores de portadores de deficiências neurodegenerativas, síndromes e movimentos de neurodiversidades constituam, eles mesmos, "formas de resistência", ainda que de certa forma não esteja muito claro como isso se daria - admitindo, quem sabe, o "cuidado de si" como "desapego de si" e mudando a ênfase do aprimoramento da atenção e memória para uma "desatenção atenta", ou ainda, diante da fragilidade de algumas formas de vida, fazendo notar que o "Yes, we can" não é mais verdadeiro que a realidade do "não posso".

Assim, ocultos nas práticas de aprimoramento cognitivo - farmacológica, neuroascese, autoajuda cerebral, entre outras -, estão uma lógica econômica e um pensamento político que se volta para a alocação daquilo que Foucault (2008b) chama de recursos raros. Há certa preocupação em diferenciar os potenciais de trabalho e consumo que podem ter maior efeito econômico, destacando-se aquelas qualidades que são causalmente relacionadas ao cérebro e a figura do sujeito cerebral. É nesse registro que apresentaremos no próximo capítulo algumas considerações sobre o que pensamos ser uma espécie de economia contemporânea dos afetos e da cognição - especialmente no espaço escolar -, representada por um campo do saber que nas últimas décadas vem sendo chamado de neuroeducação. Além disso, discutiremos certo agenciamento bioquímico da obediência, sinalizando, por último, algumas possíveis forças de resistência a esse mesmo governo do noûs. 


\section{CAPÍTULO 4}

\section{NEUROEDUCAÇÃO, OBEDIÊNCIA BIOQUÍMICA E RESISTÊNCIA}

Fundamentando-se na figura ontológica do sujeito cerebral ${ }^{144}$, isto é, na ideia de que somos a propriedade da "cerebralidade" - mas também em descobertas neurocientíficas, tecnologias de imageamento, softwares computacionais, popularização do cérebro pelas mídias, psicologia e pedagogia, enfim, em uma gama de saberes e técnicas que sustentam ou se apoiam em um modo "molecular" e "neural" de ser -, a neuroeducação, como veremos, vem ganhando espaço e afirmando-se em meio a discursos que dizem que entre as suas finalidades últimas estaria a de oferecer cientificidade à pesquisa educacional e garantir o sucesso das práticas educativas (ZARO et al., 2010). Trata-se, em suma - pelo menos é o que nos parece -, da emergência de um tipo de saber que tem como objetivo (entre outros) promover uma espécie de "turbinagem" daquilo que Foucault (2008b) denominou de competência-máquina do trabalhador, mas agora por uma ótica molecularizada, ou de uma forma rearticulada do poder sobre a vida, posta em movimento naquilo que existe de mais sutil no âmbito da materialidade do corpo - voltando-se para o que ainda não é ato ${ }^{145}$, mas plasticidade ${ }^{146}$ e potência.

Formar capital humano, formar, portanto, essas espécies de competênciamáquina que vão produzir renda, ou melhor, que vão ser remuneradas por renda, quer dizer o quê? Quer dizer, é claro, fazer investimentos educacionais. [...] poder-se-ia fazer igualmente a análise dos cuidados médicos e, de modo geral, de todas as atividades relativas à saúde dos indivíduos, que aparecem assim como elementos a partir dos quais o capital humano poderá ser primeiro melhorado, segundo ser conservado e utilizado por maior tempo possível. (FOUCAULT, 2008b, p. 317-318).

Se na análise neoliberal o simples tempo de afeto consagrado pelos pais a seus filhos,

\footnotetext{
${ }^{144}$ Poderíamos também falar aqui de um self neuroquímico.

${ }^{145}$ De acordo com a neurociência cognitiva, estímulos adequados a cada faixa etária são capazes de promover mais conexões sinápticas, ou seja, pressupõe produzir conexões que ainda não existem no cérebro. Entendemos que esse trabalho de produção de estímulos cerebrais se assemelha à atividade de um artesão que, mesmo antes de dar forma a um pedaço de argila, o massageia oferecendo-lhe uma consistência - estimula um corpo potente ainda sem aspecto -, mas só depois cria uma configuração. Assim, o biopoder, que atua normalmente sobre os corpos, agora parece estar se detendo também em suas potências, ou no antes da forma. Pensamos que essa tendência também ocorre na manipulação genética, embora não seja intenção nos determos nela.

${ }^{146}$ Segundo Malabou (2014), embora o termo "plasticidade" seja bastante recorrente na neurobiologia atual, ele já vinha sendo usado também em outros contextos, como no filosófico (Hegel) e estético (Goethe). Apesar das especificidades de cada um desses usos, o termo plasticidade refere-se a uma noção comum que envolve o trabalho do tempo por meio de um sistema, diz respeito à maneira como um sistema se pode transformar de dentro sem se dissolver. Então, diz respeito à ideia de metamorfose ou à mudança radical de uma interioridade.
} 
como já nos mostrara Foucault (2008b), serviria para estimular a produção de competênciamáquina - um tipo de capital humano que poderia ser adquirido -, agora, somado a esse estímulo, mas por uma ótica que pretende ser científica, os neurossaberes contemporâneos dedicam-se também, alinhando-se ao discurso educacional, a capturar, triar e intervir na estrutura somática/cerebral dos indivíduos, propondo corrigir, melhorar, transformar e conservar suas capacidades e aptidões. Do problema do tempo dos afetos, ou pelo menos de um vocabulário que o trata nesses termos, passamos então, como exemplo, para um outro que se preocupa com o tempo da produção de conexões sinápticas ${ }^{147}$. De outro modo, a estratégia da governamentalidade neoliberal está sendo como que afunilada, ou mesmo dilatada, movese em direção a práticas que envolvem o conhecimento e a manipulação de certa plasticidade somática.

[...] os modelos de controle do corpo são microprotéticos: agora o poder atua por meio de moléculas incorporadas ao nosso sistema imunológico; o silicone toma a forma de seios, neurotransmissores alteram nossas percepções e comportamentos; hormônios produzem seus efeitos sistêmicos sobre a fome, o sono, a excitação sexual, a agressividade e a decodificação social da nossa feminilidade e masculinidade. (PRECIADO, 2018, p. 86).

Ainda que o sucesso do aprimoramento humano e a condução das condutas dos indivíduos, em especial as dos aprendizes em idade escolar, não sejam garantidos pelos novos saberes neurais, há uma clara tentativa de sequestrar e direcionar certa potência cognitiva ${ }^{148}$. Aliás, aquilo que tradicionalmente é entendido por mente, cognição ou disposição intelectiva, independentemente de seus modos de interpretação ou de qualquer polêmica filosófica, a muito vem sendo caricaturado por meio da imagem de uma tabuleta sobre a qual se pode escrever alguma coisa, mas que, a princípio, não tem nada escrito. A mente é considerada, em suma, pura potência. A neuroeducação, conscientemente ou não, parece estar sendo projetada para agir sobre essa potência, isto é, não nos padrões de conectividade neural que o cérebro já

\footnotetext{
${ }^{147}$ O termo sinapse foi proposto por Sherrington no fim do século XIX (hoje o termo indica uma junção neuromuscular). Designa o local de comunicação entre os neurônios, o local em que ocorre a transmissão de informações (químicas ou elétricas) entre eles. Estima-se que uma única célula nervosa possa fazer mais de mil sinapses. Geralmente ela ocorre entre o axônio (prolongamento celular cuja função é transmitir para outras células os impulsos nervosos provenientes do corpo celular) de um neurônio e o dentrito (prolongamento de uma célula neural que conduz os estímulos captados no ambiente ou em outras células) de outro.

${ }^{148}$ Para Preciado (2018), no entanto, o que parece estar em jogo não é necessariamente a potência cognitiva talvez porque privilegie o órgão cerebral -, mas certa potência gaudendi (potência de excitação), uma força orgástica que não privilegia nenhum órgão e reúne, ao mesmo tempo, todas as forças somáticas e psíquicas, colocando em movimento recursos bioquímicos e todas as estruturas da "alma" (aquilo que o capitalismo necessita e põe em ação). Porém, para o que nos interessa, uma vez que estamos focando os efeitos de saber e poder do sujeito cerebral, é mesmo a potência cognitiva, ainda que não desconsideremos uma potência de excitação.
} 
possui, mas nas conectividades que ele ainda não tem e que no futuro pode vir a ter - fala-se, assim, em plasticidade, disposição neural para a aprendizagem, excitação por neurotransmissores e, ainda, aprendizagem permanente para todos, aprender a aprender (OCDE, 2003) etc.

A lógica por trás desses (neuro) saberes sobre a educação, ou neuroeducação, segue a mesma linha do aprimoramento cognitivo farmacológico, ou bioquímico, e da neuroascese, isto é, expressa uma preocupação contemporânea, movida pela racionalidade neoliberal, em estimular a eficiência, a competitividade e aumentar a performance produtiva dos indivíduos. O alvo é o indivíduo-empresa, ou pelo menos a potência-empresa dos indivíduos, que deve ser mecânica ou bioquimicamente excitada. Nessa direção, em meio à literatura neuroeducativa, encontramos títulos que sugerem - associados à ideia de "turbinagem" -, certo incentivo ao aumento da potencialidade do desempenho, tais como: The brain, education, and the competitive edge ${ }^{149}$ (CAINE; CAINE, 1994), Enriching the brain: how to maximize every learner's potential ${ }^{150}$ (JENSEN, 2006), Research-based strategies to ignite student learning: insights from a neurologist and classroom teacher ${ }^{151}$ (JUDY WILLIS, 2006), Compreendendo o cérebro: rumo a uma nova ciência do aprendizado (OCDE, 2003), entre muitos outros, o que, de certo modo, corrobora um esquema positivo do poder que se vai manifestar como excesso de estímulos, informações e impulsos, modificando a economia da atenção e aliando-se a discursos motivacionais que repetem, como a um mantra, "Yes, we can".

Nesse contexto, os modos de ser que contrariam a positividade do desempenho, como é o caso da desatenção, falta de memória, dificuldade em aprender e o fracasso na competição, ou tudo aquilo que não se encaixa - e/ou desobedece - no mantra motivacional e na cultura da boa performance, tendem a ser concebidos como desvios, fraquezas e/ou patologias biomedicalizáveis ${ }^{152}$, ainda que muitas vezes escape a biomedicalização. O que está em jogo, como já indicamos, é o aumento da competência-máquina dos indivíduos, mas essa

\footnotetext{
${ }^{149} \mathrm{O}$ cérebro, a educação e a vantagem competitiva (tradução nossa).

${ }^{150}$ Enriquecendo o cérebro: como maximizar o potencial de aprendizagem de todos os alunos (tradução nossa).

${ }^{151}$ Estratégias de como motivar a aprendizagem dos alunos: insights de um neurologista e professor de sala de aula (tradução nossa).

${ }^{152} \mathrm{O}$ conceito de biomedicalização se fundamenta na teoria foucautiana do biopoder e também nos debates propostos por Rabinow (1999). Enquanto a medicalização se centra no adoecimento, na enfermidade, no cuidado e na reabilitação, a biomedicalização enfatiza a saúde como um imperativo moral, o que importa é a internalização do autocontrole, vigilância e transformação pessoal. O processo de biomedicalização parece ter se beneficiado das transformações ocorridas no modelo de negócios da indústria farmacêutica, que passou de centrado na educação dos profissionais da saúde, os quais prescreviam seus produtos, para um outro centrado no paciente/consumidor, que então começa a se preocupar com as capacidades de remodelação de sua própria vitalidade.
} 
máquina já não se resume a um hardware disciplinável, senão a um software que se acredita manipulável, modelável e remodelável.

Assim, em oposição à ideia cartesiana de corpo - um mecanismo composto de engrenagens, tal como os dispositivos de um relógio -, surge um novo sujeito: eletroquímico, hormonal, excitável, neural e, principalmente, reprogramável. Tokuhama-Espinosa ${ }^{153}$ (2008, p. 6, tradução nossa), por exemplo, mostra que, diferentemente de outras neuroáreas ${ }^{154}$ que se dedicam - de maneira exclusiva - à compreensão de como acontece a aprendizagem, a neuroeducação estaria mais interessada em "determinar como os seres humanos devem ser (mais bem) instruídos no processo de maximização de suas potências" ${ }^{155}$. E, na mesma direção, ao fazer a apresentação do livro Making connections teaching and the human brain ${ }^{156}$ (CAINE; CAINE, 1994), ainda nos primeiros parágrafos, Donna Carter deixa claro o potencial de aproximação entre neurologia, educação e pensamento neoliberal ao afirmar que uma (re)conceituação do ensino fundamentado no conhecimento do cérebro poderia, além de colaborar com o melhoramento da aprendizagem dos estudantes, "produzir com mais sucesso o trabalhador que é solicitado pelos negócios e pela indústria - com abertura, flexibilidade e desenvoltura" ${ }^{157}$ (CAINE; CAINE, 1994, p. 6, tradução nossa).

Em vez de pessoas estáveis e previsíveis, tal como era exigido pela lógica fabril e oferecido pelo modelo disciplinar de ensino, o modo atual de produção capitalista estaria pedindo sujeitos dinâmicos, inovadores e empreendedores, e para isso o conhecimento das bases biológicas da aprendizagem e a plasticidade dos esquemas cognitivos poderiam servir de ferramenta para a construção e excitação desses novos sujeitos - ou dessas novas subjetividades. De algum modo, a estrutura orgânica, neural e biomolecular dos indivíduos está se tornando uma espécie de "esconderijo" da própria biopolítica, ou seja, "o corpo moderno biopolítico, como sugeriu Foucault, não é mais uma superfície unidimensional em que o poder, a lei e a punição serão inscritos, e sim uma interioridade densa em que a vida, e também o controle político, ocorre sob a forma de troca, tráfego e comunicação"

\footnotetext{
${ }^{153}$ Tokuhama-Espinosa defendeu sua tese de doutorado sobre neuroeducação em 2008, que desde então vem sendo tomada como ponto de referência na reflexão acerca do tema, principalmente em virtude de um mapeamento que a autora realizou sobre as interseções entre neurologia, psicologia e educação nos últimos trinta anos anteriores a seu trabalho.

${ }^{154}$ A referência a essa afirmação pode ser conferida na citação traduzida no texto e citada integralmente em nota de rodapé sequencial.

${ }^{155} \mathrm{O}$ desenvolvimento completo é: "The goal of neuroeducation, unlike the goals of cognitive neuroscience or neuropsychology, is not only to understand how humans best learn, but rather, to also determine how they should best be taught to maximize their potential".

${ }^{156}$ Conectando o ensino e o cérebro humano (tradução nossa).

157 " [...] we can more successfully produce the worker requested by business and industrywith - open-endedness, flexibility, and resotccefulness".
} 
(PRECIADO, 2018, p. 172).

O indivíduo e a sociedade, em suma, estariam sendo impelidos a remodelar-se e potencializar-se, incluindo ${ }^{158}$ aqui a cognição e os afetos - movidos principalmente por interesses econômicos, como testemunham os incentivos para uma aprendizagem fundamentada no conhecimento do cérebro, oferecidos pela Organização para a Cooperação e Desenvolvimento Econômico (OCDE, 2003) -, e a neuroeducação, ainda que sua eficácia não seja totalmente comprovada ${ }^{159}$, como veremos a seguir, seria mais um instrumento para possibilitar essa tarefa, prometendo, entre outras coisas, fazer com que as pessoas aprendam mais em menos tempo, acelerem a capacidade normal de atenção, potencializem a memória, ou simplesmente retardem o declínio cognitivo causado pelo envelhecimento. A neuroeducação emerge, assim, como o efeito de verdades postuladas em meio ao discurso do sujeito cerebral (e/ou self neuroquímico), uma espécie de signo indicativo do poder contemporâneo que atua sobre a vida e, na mesma direção, como efeito de saberes e tecnologias que tratam o humano - no contexto da biopolítica contemporânea e da ideia de "uma forma de vida emergente" -, molecularmente e de forma neural.

\subsection{PRÁTICAS NEUROEDUCATIVAS}

Sabemos, até mesmo em razão da grande popularização do cérebro pelos veículos de comunicação de massa, que o componente básico do processamento da informação no cérebro é o neurônio, uma célula capaz de acumular e transmitir atividade elétrica, veiculando “informações entre a periferia do sistema nervoso central, e, reciprocamente, entre as diversas regiões do sistema nervoso" (FIORE, 2008, p. 22). Como indicado anteriormente, existem aproximadamente 100 bilhões de neurônios em um cérebro humano adulto (ANDREASEN, 2003), e cada um deles é capaz de conectar-se a milhares de outros neurônios, fazendo com que os sinais de informação fluam em grande quantidade e em muitas direções ao mesmo tempo. De acordo com pesquisadores (DAMÁSIO, 1996; ANDREASEN, 2003; ROSE, 2006), quando um grupo formado por muitos neurônios entra em atividade simultaneamente ${ }^{160}$

\footnotetext{
158 Também poderíamos acrescentar aqui a performance corporal e/ou a aparência, como a busca pelo corpo perfeito (uso de próteses, implante de silicones, plásticas, academias, hormônios, pílulas etc.) e o ideal do esporte-aventura (EHRENBERG, 2010).

${ }_{159}$ Segundo alguns pensadores (ORTEGA; ZORZANELLI, 2010), em torno da neuroeducação também se desenvolvem muitos "neuromitos", especulações que não se mostram comprováveis, como a ideia de que só usamos dez por cento de nossa capacidade cerebral, ou que quem usa o lado esquerdo do cérebro possui um raciocínio lógico mais desenvolvido, comparado aos que usam mais o lado direito, os quais seriam mais criativos, ou que crianças que ouvem músicas clássicas, como as de Mozart, tornam-se mais inteligentes.
} 
, ele acaba por produzir "padrões de atividade", o que corresponde, na linguagem da neurociência cognitiva, à formação de determinado estado mental.

A questão é que, se os estados mentais, comumente postulados pela neurociência, são produzidos por padrões de atividade neural, o "conhecimento" - entendido pela ciência do cérebro como aquilo que dirige o fluxo cognitivo de um estado mental para outro (FIORE, 2008) - acaba por ser decodificado nas próprias conexões neurais. Isso significa, pelo menos dentro do discurso da neurociência cognitiva ${ }^{161}$, que a aprendizagem deve ocorrer pelo aparecimento de novas ligações neurais (sinapses) - ou também pelo fortalecimento ${ }^{162}$ ou enfraquecimento de sinapses já existentes. Assim, dizendo muito rapidamente, a aprendizagem $^{163}$ envolveria uma modificação ou reconfiguração da própria estrutura ${ }^{164}$ anatômica do cérebro, à qual se atribuem diferentes tarefas de processamento de informações - fala-se aqui em localizações funcionais -, e seria traduzida pela formação e consolidação de ligações entre as células nervosas. Nessa direção, destaca-se que "para aprender é preciso maturação e integração de diversas áreas cerebrais envolvidas no processo" (SIQUEIRA; GURGEL-GIANNETTI, 2010, p. 79).

De certo modo, a neuroeducação ${ }^{165}$, como notamos em alguns trabalhos (TOKUHAMA-ESPINOSA, 2008; AMARAL, 2016; RIBEIRO, 2013; ZARO et al., 2010), vem ganhando fôlego mediante o discurso de que professores, pais e até mesmo os próprios estudantes precisariam conhecer as bases biológicas da aprendizagem - como estimulá-las, como otimizar a memória e a atenção, o funcionamento dos neurotransmissores, a sinaptogênese, os alimentos e as atividades que potencializam as ligações neurais, o papel das

\footnotetext{
${ }^{160}$ Movidos até mesmo por estímulos ambientais.

${ }^{161}$ Esse discurso serve de fundamento para a neuroeducação.

${ }^{162}$ Donald Hebb (1949) foi um dos primeiros pesquisadores a sugerir a relação entre processos neurais (em redes) e os fenômenos cognitivos, incluindo a própria aprendizagem. Inspirando-se no funcionamento das redes neurais naturais, o movimento conexionista (redes neurais artificiais), por exemplo, elegeu a rede como o principal instrumento de modelação da atividade cognitiva. A teoria de Hebb, dizendo de forma bastante geral, parte do pressuposto de que células que disparam juntas permanecem conectas, isto é, a ativação simultânea de células neurais leva a um fortalecimento da força sináptica (é o que nos permitiria, depois de já ter aprendido, por exemplo, dirigir um carro sem ficar prestando atenção no movimento da troca de marchas, ou tocar um instrumento musical sem focar os detalhes de suas cordas, teclados etc.).

${ }^{163}$ De acordo com alguns pesquisadores que estudam a relação entre a aprendizagem e o cérebro (COSENZA; GUERRA, 2011), durante muito tempo se acreditou que a capacidade de aprendizagem era pequena nos adultos e quase nula na velhice, mas o conhecimento atual - amparado por tecnologias de imageamento cerebral permitiu afirmar que a plasticidade nervosa, ainda que diminuída com passar dos anos, permanece pela vida inteira e, portanto, a própria capacidade de aprendizagem

${ }^{164}$ Para detectar essas atividades, muitos instrumentos tecnológicos são usados - tomografia por emissão de pósitrons, ressonância magnética funcional, estimulação magnética transcraniana, entre outros - e, ao serem combinados, permitem obter informações sobre as mudanças espaciais e temporais da atividade cerebral associadas à aprendizagem.

${ }^{165}$ Devemos observar que a neuroeducação não é um campo disciplinar ainda bem consolidado, mas é possível dizer que está em processo de rápida expansão.
} 
emoções etc. - para promover o seu aperfeiçoamento. Admite-se, ou se conjectura, que o conhecimento dos princípios da produção dos padrões de atividade neural, principalmente no âmbito da educação, possibilitaria a constituição de "um a mais cognitivo".

Assim, ao tratar da neuroeuducação, alguns pesquisadores ${ }^{166}$, esperançosamente, afirmam que uma nova geração de educadores deverá, em um futuro bastante próximo, alargar o conhecimento não apenas em relação aos conteúdos com os quais trabalham (matemática, idiomas, ciências etc.), mas também compreender como o raciocínio a respeito desses conteúdos se desenvolve no cérebro humano.

Diversas descobertas científicas recentes alimentam os debates sobre a relação entre neurociências e educação, tais como as evidências de que o direcionamento da atenção do aluno para pontos específicos do material estudado favorece a retenção de memórias, de que gestos não verbais antecedem saltos cognitivos, e de que o aprendizado linguístico baseado em morfemas e grafemas é mais eficaz do que o ensino de palavras inteiras. (RIBEIRO, 2013, p. 10 -11).

Mesmo que a neuroeducação (o cruzamento entre saberes neurocientíficos, educacionais e psicológicos ${ }^{167}$ ) seja apontada por muitos ${ }^{168}$ como uma disciplina emergente e autônoma, é possível admiti-la ainda enquanto uma tecnologia contemporânea de subjetivação, efeito de verdade do discurso do sujeito cerebral. Ela identifica o indivíduo sua inteligência, afetos, desejos, memória, aprendizagem etc. - com padrões de atividade cerebral, com neurotransmissores e com a potência de ativações sinápticas que se acredita poder estimular, modificar e ativar de forma mecânica e artificial. Trata-se, então, do aparecimento de um tipo de saber que não diz apenas (recorrendo ao cérebro) como somos ou o que somos, mas que pretende, seguindo certa lógica de estímulo ao potencial de desempenho, oferecer técnicas que nos conduzam rumo àquilo que "deveríamos" ser, isto é, atentos, possuidores de boa memória, hábeis em aprender, inovadores, flexíveis, motivados, ou, quem sabe, um tipo especial de máquina que vai produzir fluxos de renda (FOUCAULT, 2008).

Entre alguns dos temas da neuroeducação estão aqueles que tratam dos períodos mais receptivos para o desenvolvimento do cérebro e suas implicações para um currículo de

\footnotetext{
${ }^{166}$ Disponível em: http://revistas.unisinos.br/index.php/educacao/article/viewFile/edu.2014.181.02/3987. Acesso em: 18 jan. $1819 . \quad$ Disponível em: http://www.sbece.com.br/2015/resources/anais/3/1428242805_ARQUIVO_trabalho_sbece_2015.pdf. Acesso em: 18 jan. 2019.

${ }^{167}$ Segundo Tokuhama-Espinosa (2008), esse diálogo já havia sido proposto por H. Gardner, ainda em 1974.

${ }^{168}$ Por exemplo, Tokuhama-Espinosa (2008); Amaral (2016); Ribeiro (2013); Zaro et al. (2010).
} 
aprendizagem relacionado à idade ${ }^{169}$ e outros: especulações neurocientíficas e educacionais que abordam, conjuntamente, a dificuldade da alfabetização e do aprendizado matemático, principalmente na infância; formas de remediar ou prevenir problemas como dislexia e acalculia; os limites do cérebro humano, questionando se é possível a qualquer pessoa se igualar ao desempenho de um Leibniz, de um Mozart ou de um Bill Gates por meio de boa educação e ambiente "enriquecido" (JENSEN, 2006); a dificuldade de desaprender ou corrigir maus hábitos; como facilitar a cooperação entre sistema límbico (emocional) e córtex cerebral (cognitivo). Enfim, a lista de assuntos é bastante extensa e em determinados momentos chega a sugerir o que alguns chamam de neuromitos (ORTEGA; ZORZANELLI, 2010), isto é, ultrapassa o que se poderia inferir com base na própria ciência cerebral, tomando proposições duvidosas ${ }^{170}$ como sendo verdades passíveis de serem aplicadas. No entanto, o que se mostra comum e atravessa a maioria dos temas abordados pela neuroeducação é a ideia de que o indivíduo pode ser modelado e, principalmente, potencializado, o que nos conduz novamente ao tema da produção de capital humano.

Como exemplo, podemos trazer aqui o discurso da neuroeducação no qual se ressalta que o cérebro é o órgão que mais consome glicose, e a administração dessa substância antes do aprendizado potencializaria a memória - o que nos leva à ideia, já bastante consolidada, de que a má nutrição afeta negativamente a aprendizagem: "parece se dever a uma dessensibilização dos receptores de glutamato do tipo NMDA, que são necessários para o aprendizado de longo prazo" (RIBEIRO, 2013, p. 10). Outro fator neurocientífico importante para o melhoramento da aprendizagem, dizem os pesquisadores (RIBEIRO, 2013; OLIVEIRA, 2014), refere-se ao modo como reagimos às recompensas, por isso, além de questionarem o modelo de ensino tradicional, também sugerem técnicas e estratégias

\footnotetext{
${ }^{169}$ De acordo com Amaral (2016), há aqueles que defendem, desde o início do século XXI - século do cérebro -, até mesmo uma modificação dos currículos e a adoção de métodos de ensino que sejam fundamentados no conhecimento do sistema nervoso. O autor mostra, por exemplo, que desde 2011 a fundação norte-americana James S. MacDonnell vem financiando encontros em países da América Latina - American School for Education, Cognitive And Neural Sciences (LASchool) - com o propósito de articular os novos saberes neurocientíficos e a educação. O mesmo estaria acontecendo na Europa, nos Estados Unidos e também Canadá, por meio de empreendimentos como os realizados pela Internacional Mind, Brain And Education Society (IMBES), e, no Brasil, o esforço de articulação entre essas áreas ficaria evidente ao se observar a crescente inclusão de temas neurocientíficos nos cursos de graduação em pedagogia e nas formações continuadas, mesmo não sendo uma exigência obrigatória de suas grades curriculares - fala-se em "neuropsicopedagogia", "neurociências e aprendizagem" etc.

${ }^{170}$ Ao mesmo tempo em que as potencialidades do cérebro se tornaram assuntos midiáticos, concepções falsas sobre o cérebro também começaram a circular: uso de apenas dez por cento do cérebro; funcionamento dos hemisférios esquerdo e direito como independentes; pedagogias multissensoriais (estimulação visual, auditiva e cinestésica); sugestão de beber bastante água para melhorar a aprendizagem; fazer os recém-nascidos ouvirem músicas clássicas etc. A proliferação dos neuromitos deve-se, sobretudo, à expansão de programas educativos ditos baseados no cérebro.
} 
motivacionais em meio ao ambiente formal da educação.

Os reflexos desse tipo de discurso - incluindo também o de autoajuda, como apontamos anteriormente (neuroascese) -, o qual muitos acreditam fundamentar-se em saberes neurais, vêm mostrando-se presente em muitas práticas pedagógicas atuais. Para Marín-Díaz (2015), livros com conteúdo motivacionais circulam amplamente nas prateleiras de livrarias e escolas, sendo sugeridos como material de apoio a práticas educativas do ensino fundamental, aparecendo ainda no espaço universitário e nos processos de formação inicial e permanente dos próprios professores. Entre os argumentos usados para apoiá-los, destaca-se aquele que diz que os mecanismos de motivação e recompensa, quando ativados no cérebro "[...] liberam dopamina, que é uma substância neuromoduladora capaz de modificar as atividades elétricas e dos neurônios" e, mais, liberaria outro neurotransmissor, "a ocitocina, responsável pelo prazer e pela colaboração" (HENNEMMAN, 2015) 171. Assim, há quem afirme, acreditando "seguir" os preceitos da neurociência, que, "se o aluno recebe um elogio do professor por determinada situação, com certeza irá querer repetir a ação para receber novos elogios" (HENNEMMAN, 2015)

A OCDE, no relatório feito por Christopher Ball (OCDE, 2003), ao se referir ao tema da motivação e potencialização da aprendizagem, fazendo alusões às ciências do cérebro e à noção de sujeito cerebral para justificar práticas pedagógicas a serem implementadas pelos países-membros no século XXI, considera fator motivacional e meio de estimulação cerebral a escolha das disciplinas pelos próprios estudantes, seus gostos e satisfações pessoais ${ }^{173}$, o ambiente e a educação doméstica (formal), o "financiamento do aprendiz" em lugar da instituição de ensino, o alinhamento do currículo escolar ao princípio liberal de "confiar na demanda do aluno" (OCDE, 2003, p. 42) etc. Enfim, o discurso do cérebro é posto lado a lado ao projeto liberal de governo da vida, e o estudante é impelido a tornar-se, por sua própria conta e risco, um autoempreendedor ou um tipo particular de cérebro que se treina para o sucesso e o gozo, ou, ainda, uma competência-máquina motivada, excitável e com muita

\footnotetext{
${ }^{171}$ Disponível em: http://neuropsicopedagogianasaladeaula.blogspot.com/2015/10/motivacao-como-ferramentade.html. Acesso em: 1 fev. 2019.

${ }^{172} \mathrm{O}$ sistema neural, como justificam alguns apoiadores da neuroeducação (HENNEMMAN, 2015; OLIVEIRA, 2014), por ser provido de uma conexão em rede, formaria um contínuo entre os processos cognitivos e afetivos que seriam fortalecidos pela repetição dos mesmos estímulos. E, em meio a palavras de ordem motivacionais, como "pensamento positivo", superação, autoconfiança, melhoramento, aumento da criatividade, crescimento pessoal, "Yes, we can" etc., destacam-se também aquelas que se referem a "ambientes enriquecidos", "enriquecimento do cérebro" e "ativação de neurotransmissores" (JENSEN, 2006).

173 "A educação infantil precisa levar em conta as características mentais e de conceituação das crianças pequenas, assim como seu modo preferido de aprender, isto é, por meio da brincadeira" (OCDE, 2003, p. 61).
} 
ocitocina.

Tudo isso, de certa forma, acaba por corroborar a análise foucaultiana do poder, uma vez que este não pesa somente como uma força que diz não, mas desenvolve saberes, produz coisas, excita e induz ao prazer. Nessa direção, a tendência anunciada pela OCDE, e que não nos causa muita estranheza, principalmente ao levar em conta os efeitos de verdade do sujeito cerebral e da biopolítica molecular, é a sugestão de práticas de ensino e aprendizagem voltadas para maximizar aquilo que é tido como fonte promissora de capital: inteligência, criatividade e afetividade - ou, como diria Preciado (2018, p. 44-45), em um contexto ${ }^{174}$ que não nos parece muito distante, também certa potentia gaudendi, compreendida como "a soma da potencialidade de excitação inerente a cada molécula material. [...] uma força de transformação do mundo em prazer", reunindo ao mesmo tempo todas as forças somáticas e psíquicas.

Ainda, segundo a OCDE, em relatório feito por Anthony E. Kelly (OCDE, 2003), outra forma de otimizar a aprendizagem usando estratégias neuroeducativas seria explorar aquilo que é chamado de "períodos neurologicamente receptivos" - ou sensíveis. Trata-se, resumindo, da possibilidade de poder ensinar certas habilidades aos indivíduos enquanto estes estão cerebralmente mais propensos a absorvê-las, isto é, quando se verifica a existência de períodos de maior neuroplasticidade ${ }^{175}$ : “quanto mais tarde se aprende gramática, mais ativo o cérebro se torna (mas ativação cerebral quase sempre significa que o cérebro tem mais dificuldade de processar aquela tarefa: [...] pessoas que leem bem mostram menos atividade cerebral do que as que leem mal)" (OCDE, 2003, p. 84). Entre as sugestões, destaca-se, por exemplo, um projeto de revisão do ensino de idiomas - afirma-se que a aprendizagem de uma segunda língua deveria ocorrer nos primeiros $\operatorname{anos}^{176}$ de vida, e não na adolescência, como acontece na maioria dos países: “A questão é saber se os programas dos sistemas educacionais têm relação com os períodos sensíveis e se os exames de imagem funcional do cérebro vão acrescentar novas explicações em relação aos processos biológicos referentes a esses períodos" (OLIVEIRA, 2014, p. 16). Porém, vemos também que no mesmo relatório da OCDE (2003), e em vários outros artigos atuais que tratam da neuroeducação, a noção de neuroplasticidade aparece ainda para justificar a tese de que é sempre possível aprender

\footnotetext{
${ }^{174}$ No contexto do capitalismo farmacopornográfico.

${ }^{175}$ Segundo Oliveira (2014), o que se tem comprovado é que, entre o nascimento e a adolescência, novos neurônios serão acrescentados ao cérebro, novos circuitos neuronais serão construídos em consequência da interação com o ambiente e os estímulos. Esse processo desacelera no adulto, mas não é interrompido durante toda a vida.

${ }^{176} \mathrm{O}$ relatório não deixa muito claro como essa mudança curricular poderia ocorrer.
} 
"mais", seja na infância, na vida adulta ou na velhice, tenha a pessoa transtornos mentais, dificuldades na aprendizagem ou não.

Fica claro, então, que o imperativo aplicado ao ambiente educacional é a maximização, "maximizar-se pelo cérebro" ${ }^{177}$, associado, é claro, a certa obediência e controle bioquímico, tudo isso em conformidade com a noção - apontada anteriormente - de política da vida em si mesma (ROSE, 2013), ou, em outros termos, o que está valendo no contexto da biopolítica atual não é apenas ser ou aprender, ou simplesmente corrigir, mas ser mais e aprender mais: “[...] já não nos contentamos com a restauração de corpos e almas [...]. Nessa nova era, parece, somos capazes de remodelar aspectos-chaves do funcionamento de nossos corpos e de nossas almas mais ou menos à vontade" (ROSE, 2013, p. 143). No entanto, a título de sugestão para o último tópico deste capítulo, talvez caiba nos perguntar se a potência de ser, ou ser mais, não implicaria igualmente uma potência de não ser, ou, ainda, se a plasticidade produtiva não carregaria algo de destruição.

Em outra frente, há aqueles ${ }^{178}$ que vêm pesquisando e defendendo - até mesmo com argumentos fundamentados em tecnologias de imageamento cerebral - o uso de neurotécnicas de otimização da memória que recorrem ao sono. Para Sidarta Ribeiro (2013), o sono abrigaria uma combinação de reativação neural e plasticidade sináptica que, em tese, seria necessário para consolidar, mas também potencializar a memória. Ele diz, por exemplo, que uma das técnicas promissoras para melhorar a memória é associar a aprendizagem a informações sensoriais específicas, como odores ou sons, e, depois, durante o sono, reproduzir esses mesmos estímulos. Segundo o autor, algumas experiências ${ }^{179}$ demonstram que a reativação da memória durante o sono otimiza a memória declarativa ${ }^{180}$. Sugere, então, sonecas escolares antes e depois das aulas ${ }^{181}$, dicas mnemônicas, instruções pré-sono para o aumento da expectativa de utilidade de memórias específicas, entre outras.

\footnotetext{
${ }^{177}$ É interessante observar, no entanto, que há duas práticas biopolíticas associadas a educação que recorrem ostensivamente ao cérebro: a primeira, inserida num espaço economicamente elitista, apregoa a maximização cognitiva (fitness cerebral, medicamentos potencializadores da memória e atenção, entre outros mecanismos); a segunda, por outro lado, está presente nos espaços educacionais marcadamente "precários" em que predomina o discurso da obediência pelo cérebro (o cérebro torna-se uma alavanca de controle, o estudante é medicado, por exemplo, para que não "atrapalhe" a dinâmica da aula - trata-se de fazer calar, diminuir a resistência).

${ }^{178}$ Ribeiro (2013) e Wilhelm et al. (2011).

${ }^{179}$ Disponível em: https://www1.folha.uol.com.br/fsp/ciencia/fe0211200701.htm. Acesso em: 29 jan. 2019.

${ }^{180}$ A memória declarativa (ou explícita) é a memória para fatos e eventos: datas, acontecimentos, número de telefone, fórmulas matemáticas. Diz respeito ao que podemos evocar por meio de palavras e se distingue de outras formas de memória, como a associativa e de procedimentos.

181 Disponível em: https://www.blogdobg.com.br/estudo-da-ufrn-em-natal-comprova-que-cochilos-pos-aulaimpulsionam-a-aprendizagem-declarativa/. Acesso em: 29 jan. 2019.
} 
E, se lembrarmos, como explicitado em outro capítulo, que existem pesquisas no âmbito das neurociências que têm por objetivo descobrir novas formas de fazer com que os indivíduos fiquem por mais tempo acordados sem prejuízo da atenção, vemos que o sono, evitando-o ou estimulando-o, torna-se matéria, mesmo que especulativa, de manipulação e potencialização do indivíduo: "Último obstáculo - na verdade, a última das 'barreiras naturais', para usar a expressão de Marx - à completa realização do capitalismo 24/7, o sono não pode ser eliminado. Mas pode ser destroçado e espoliado" (CRARY, 2016, p. 27). Assim, na nova política da vida - radicalizando um pouco -, ao dormir o indivíduo (estudante) poderá ser convidado a maximizar a sua memória, isto é, continuar trabalhando em si mesmo; todavia, estando por muito tempo em situação de vigília (graças a substâncias bioquímicas que atuam artificialmente em seu cérebro), poderá ser cobrado ou cobrar a si mesmo por um estado de máxima atenção - principalmente se já estiver inserido na lógica da boa performance da produção capitalista. Corroborando um pouco de tudo isso, encontramos:

Os analistas da atenção acreditam que o trabalhador gestor deve ser antes de tudo um mestre na gerência da sua própria atenção. $\mathrm{Na}$ economia empresarial da atenção, o defeito atentivo não é necessariamente a incapacidade de se concentrar em um determinado aspecto. O problema do gestor executivo reside na direção ineficiente da atenção. (CALIMAN, 2012, p. 6-7).

Desse modo, é possível constatar que a positividade do poder, suas (micro) estratégias de potencialização e condução da vida, intenciona a interioridade, a molecularidade, os afetos e a cognição, chegando aos genes e aos próprios neurônios - ainda que em certos casos isso aconteça de forma especulativa, especialmente quando se percebe que proponentes e adeptos de técnicas como as neuroeducativas, como professores e pais, muitas vezes desconhecem detalhes das ciências e tecnologias do cérebro (TOKUHAMA-ESPINOSA, 2008) -, movimentando-se do laboratório para a escola, da mídia para o interior dos lares, da corporeidade plástica até o local de trabalho, atravessa o sono, os sonhos e fantasias, multiplica discursos, cria vocabulários, motiva e induz ao prazer. Da anatomia bruta (hard) dos corpos, aos poucos, o biopoder vai direcionando-se também para aquilo que existe de sutil (soft) e plástico na constituição dos indivíduos, em especial seus cérebros, e, com estes, voltase para a inteligência, para os afetos, para a criatividade e a potência de ser.

É dentro dessa realidade, a qual estamos chamando de governabilidade da vida por meio da gestão dos fenômenos mentais, que acreditamos achar-se ${ }^{182}$ as novas tecnologias de 
condução dos indivíduos e da população (neuroeducação, neuroascese, aprimoramento e correção farmacológica etc.), constituindo saberes viabilizadores da produção dos novos potenciais de produção, ou, ainda, aparecendo como ferramentas excitatórias daquilo que Foucault (2008) denomina de recursos raros. Tal fato, de certo modo, pode ser confirmado observando as propostas que, desde o início do século XXI, vem sendo ofertadas progressivamente com o objetivo de promover uma "educação pelo cérebro". Além do interesse demonstrado por grandes organizações econômicas, como é o caso da própria OCDE, tentativas de reunir saberes neurais e educacionais são vistas, por exemplo, na criação da MacDonnell Foundation ${ }^{183}$, Escola Latino-Americana de Ciências Educacionais, Cognitivas e Neurais que anualmente reúne professores e estudantes de pós-graduação de diferentes países para discutir, estudar e articular os saberes em questão; na International Mind, Brain and Education Society (IMBES) ${ }^{184}$, que desde 2004 vem incentivando o diálogo entre ciências cognitivas, neurociências, genética e educação. Essas investidas acontecem também em fóruns ${ }^{185}$ mundiais, como o de Nova York (Estados Unidos), que discutiu sobre os mecanismos do cérebro e a aprendizagem das crianças; em Granada (Espanha), que debateu sobre os mecanismos do cérebro e a aprendizagem dos jovens; em Tóquio (Japão), que abordou o cérebro e a aprendizagem dos idosos. Ao olhar mais pontualmente para a realidade brasileira, podemos notar que esses investimentos se refletem também em situações que já parecem comuns, como na expansão de disciplinas de "neuropsicopedagogia", "neurociências e aprendizagem", além do aparecimento de programas específicos de pós-graduação em neuroeducação ${ }^{186}$.

Então, seguindo a esteira de Foucault (1995), podemos dizer que o poder é produtivo. Ele produz realidades, saberes e, na mesma direção, múltiplas possibilidades e condições de sermos sujeitos e, mesmo que se refira a um tipo específico, cerebralizado e normalizado, o poder se caracteriza por ser um conjunto de "ações sobre ações possíveis", opera sobre o campo de possibilidade em que se inscreve o comportamento dos sujeitos ativos, "[...] incita,

\footnotetext{
${ }^{182}$ No entanto, pensamos que a neuroeducação não figura como o único nem o mais importante saber desse projeto de governamentalidade da vida por meio dos estados mentais; existem outros, como as ciências cognitivas, ciências da informação, psiquiatria, psicologia, farmacologia, neurologia, biomedicina etc. A neuroeducação simplesmente exemplifica a realização desse projeto no âmbito educacional, é um meio de estimular aquilo que Foucault (2008) chama de capital humano adquirido.

${ }^{183}$ Disponível em: http://2015.laschool4education.com/. Acesso em: 3 fev. 2019.

${ }^{184}$ Disponível em: https://www.imbes.org/. Acesso em: 2 fev. 2019.

$185 \quad$ Disponível em: https://www.oecd-ilibrary.org/docserver/9789264174986-sumpt.pdf?expires $=1550597065 \& \mathrm{id}=\mathrm{id} \&$ accname$=$ guest \&checksum=E6CAB4F23A3A28DF. Acesso em: 2 fev. 2019.

${ }^{186}$ Disponível em: http://www.neuroeducacao.com.br/; http://www.posugf.com.br/cursos/pos-graduacaoead/psicologia/3493-neuroeducacao. Acessos em: 2 fev. 2019.
} 
induz, facilita ou torna mais difícil, amplia ou limita, torna mais ou menos provável" (FOUCAULT, 1995, p. 243). O poder é produtivo no sentido de que também é capaz de desenvolver, organizar, reorganizar e propagar novas formas e meios de condução da vida. $\mathrm{O}$ seu exercício consiste em conduzir condutas, "em ordenar a probabilidade" (FOUCAULT, 1995, p. 244). A questão, porém, é que em meio aos novos instrumentos de ordenação, entre os cálculos de produção e alocação de recursos raros - requeridos pela lógica neoliberal -, passaram-se a incluir características humanas que são moleculares, hormonais, neurais, plásticas e modificáveis, e em seu vocabulário entraram termos como risco, suscetibilidade, aprimoramento (enhancement), desempenho, atenção, memória, inteligência, flexibilidade, entre outras.

A neuroeducação, de certo modo, emerge como um instrumento ordenador que aloca, contemporaneamente, o capital humano, resultado de uma relação de poder e saber que subjetiva e também governa, fazendo-se presente no jogo das novas representações identitárias, nas tentativas de oferecer cientificidade ao processo de ensino e aprendizagem, está alinhada aos discursos cognitivistas, neurológicos, mas também é reflexo da divulgação do cérebro pelos meios de comunicação de massa, dos marketings de laboratórios farmacêuticos que produzem psicofármacos, da literatura de autoajuda, empresas de exercícios cerebrais, demandas envolvendo o aumento da produtividade, disputas pelos melhores empregos e maiores salários etc. Enfim, o poder apropria-se das peculiaridades que envolvem as relações do corpo com os seus processos vitais: trata-se, então, de "biopoder".

No entanto, como nos lembra Foucault (1995), as “ações sobre ações possíveis", que correspondem ao próprio exercício do poder, acontecem apenas quando existem sujeitos livres, quando se pressupõe indivíduos que têm diante de si um campo de possibilidade em que muitas condutas, contracondutas, reações e comportamentos podem ser desencadeados. A relação de poder e o impulso da liberdade, como muito bem sugere o pensador francês, não são separáveis, ocorrem sempre em um campo de lutas. E, diante de uma governamentalidade da vida que tende a ser feita por meio da condução dos estados mentais - pressupondo técnicas de subjetivação que reforçam uma ontologia cerebral -, caberia nos perguntar, então, qual é o espaço da intransigência da liberdade, ou como se daria uma reação à objetivação cerebral do sujeito.

\subsection{2 (Bio) Medicalização no espaço escolar: aprimoramento e desobediência}


Em capítulo anterior discutimos acerca do aprimoramento farmacológico e sua relação com a produção de capital humano, agora, retomando rapidamente esse debate, mas com outro foco, pensando principalmente no espaço escolar e nos processos de subjetivação que o atravessam, falaremos um pouco sobre o uso de fármacos, mas não enquanto ferramenta de potencialização da capacidade produtiva - ou tão somente -, e sim como dispositivo que estimula também certa obediência bioquímica ${ }^{187}$. Apesar de Byung-Chul Han (2017) afirmar que estamos na era do desempenho e que o sujeito de desempenho é mais rápido e mais produtivo que o sujeito da obediência - como apontamos em outro momento -, o poder sobre a vida, pelo menos é o que nos parece, não cancela também certo dever da vida.

Para iniciar essa discussão, recorreremos então a uma experiência vivida e poeticamente relatada pelo escritor contemporâneo Manoel de Barros (1916-2014), o "surrealista pantaneiro". Embora não fale sobre a questão da medicalização, o poeta retrata muito bem uma espécie de expectativa dos adultos em relação a seus pupilos, principalmente no que diz respeito ao enquadramento destes em uma boa performance produtiva, o que implicaria igualmente uma responsabilização pela correção dos seus "desvios" e pela gestão de sua obediência. Assim, ao completar 85 anos, Manoel de Barros escreveu algumas memórias sobre o delicado momento de sua infância/adolescência, em que tornou público, em especial para seus pais e irmãos, o que desejava fazer de sua vida nos anos que sucederiam. Eis o texto:

\section{O fraseador}

Hoje eu completei 85 anos. O poeta nasceu de treze. Naquela ocasião eu escrevi uma carta aos meus pais, que moravam na fazenda, contando que eu já decidira o que queria ser no meu futuro. Que eu não queria ser doutor. Eu queria ser fraseador. Meu pai ficou meio vago. A mãe abaixou a cabeça. Então meu irmão mais velho perguntou: Mas esse tal fraseador bota mantimento em casa? Eu não queria ser doutor, eu queria ser fraseador. Meu irmão insistiu: Mas se fraseador não bota mantimento em casa, nós temos que botar uma enxada na mão desse menino para ele deixar de variar. Meu pai continuou meio vago. Mas não botou enxada. (BARROS, 2003, p. 23).

Vemos, nessa pequena recordação, independentemente de qualquer interesse em elementos literários, uma preocupação dos pais do menino com seu futuro e potencial de renda, o que é muito comum na maioria das famílias ${ }^{188}$. Notamos também certa insistência do

\footnotetext{
${ }^{187}$ Essa obediência, no entanto, também entra no cálculo da produtividade.

${ }^{188}$ A família do poeta Manoel de Barros, no período em que foram retratadas essas memórias, era proprietária de terras no então estado de Mato Grosso, e o menino estudava em um colégio interno na cidade de Campo Grande, onde estava sendo preparado e incentivado a entrar na carreira jurídica.
} 
irmão mais velho em sugerir uma correção daquilo que lhe parecia ser um "desvio" - o desejo de seu irmão mais novo de não ser doutor, mas fraseador. Essas preocupações, de alguma maneira, corroboram a ideia de que a boa performance, o sucesso em "botar mantimento em casa" e o enquadramento social são elementos orientadores de parte das atividades escolares, bem como da própria educação familiar. No caso específico do poeta, quando da ocasião em que revelou sua escolha, ele acabou por se mostrar - de acordo com as expectativas que se impunham a ele - um desviante, um sujeito fora de prumo, e o "argumento" disciplinador sugerido para lhe corrigir, como ele mesmo indica, foi "botar uma enxada na mão para deixar de variar". Felizmente, o pai do menino não acatou a sugestão, mesmo tendo ficado "meio vago", porém essa ${ }^{189}$ e outras formas consideradas correcionais, algumas até bastante violentas $^{190}$, vêm sendo sugeridas há muito tempo como meios de tratamento dos "desviantes".

A questão é que, agora, passado o tempo do nascimento do poeta menino, e mesmo da sua morte, a maneira de corrigir os desvios modificaram-se, não se trata mais de simplesmente "botar uma enxada na mão" do "variante", nem de dar um "coro no filho que está ficando meio gayzinho"191 - como sugeriu há algum tempo certo deputado brasileiro -, ou ainda submeter o corpo da criança a uma vigilância panóptica nos moldes foucautianos de vigiar e punir, mas de interferir na bioquímica e adentrar na molecularidade daqueles que são considerados de difícil assujeitamento. No atual século, o ponto de referência para se falar em "desvios" humanos parece ser cada vez menos a sociedade, suas relações interpessoais e valores morais, e cada vez mais o órgão cerebral, neurotransmissores, padrões sinápticos, genes e hormônios, e, em vez de "botar enxada na mão", corrige-se com medicamentos.

Assim, o "desvio" não se justifica atualmente pela "estranha" escolha de uma criança em ser fraseador ou na crença de que o seu quintal é maior que o mundo, mas talvez em desejar ser um fraseador e não perceber o "tamanho do mundo" por causa de algum transtorno neuroquímico identificado por um perito da vida (ROSE, 2013) - ou por algum professor que percebeu no aluno uma figura "ausente", "viajante lunar" ou demasiadamente "hiperativo". Com isso, a estratégia correcional é modificada, e, como sugere Preciado (2018, p. 2.017), em sua versão interna, “o design arquitetônico de Bentham reivindica seu lugar em outra escala: a pílula".

O saber médico, nesse contexto, aparece então como o recurso, por excelência, mais eficiente para a condução dos indivíduos "difíceis", "transgressores", “imorais",

\footnotetext{
${ }^{189}$ Típico da educação em regiões rurais.

${ }^{190}$ Disponível em: https://www.youtube.com/watch?v=QJNy08VoLZs. Acesso em: 1 mar. 2019.

${ }^{191}$ Disponível em: https://www.youtube.com/watch?v=QJNy08VoLZs. Acesso em: 1 mar. 2019.
} 
“impulsivos”, “desatentos”, entre outros. Foucault (2013c) já deixara claro que nas sociedades ocidentais dos últimos séculos a medicina acabara por substituir a Igreja na tarefa de classificar os infratores, e agora não teríamos mais hereges, bruxas, criminosos e "variantes", simplesmente, mas pessoas com transtornos considerados biologicamente "tratáveis", isto é, medicalizáveis. Se a medicina do século XVII ao fim do século XIX, como assinala Foucault (2015), prestou-se a um processo de sanitarização e higienização social, vemos que após esse período e até os dias atuais ela vem extrapolando a própria ciência médica e ampliando a sua ação para objetos que antes lhe eram estranhos. Hoje ela serve também para "acalmar" pais e professores, diminuir-lhes o "peso" da difícil tarefa de educar. Auxilia na obediência, direciona a atenção e, eventualmente, corrige ainda aqueles que demonstram demasiado interesse em frasear ${ }^{192}$ ou que durante as aulas divagam e ficam "vagando no mundo lunar".

E, fazendo uma pequena comparação, talvez pudéssemos dizer que Fernando Pessoa (o poeta), tranquilamente, poderia ser diagnosticado hoje como alguém que possui transtorno dissociativo de personalidade, ser medicado por causa de seus heterônimos, tornar-se "obediente" e ser enquadrado nas estatísticas de produtividade. E o homem do subsolo na narrativa de Dostoievski (2000) não diria mais que é doente, mau e desagradável porque sofre do fígado, mas talvez porque possui uma disfunção neuronal ou algum transtorno como o pânico - então o interesse por ele não seria mais por questões existenciais, e sim apenas como um caso a mais de indivíduo neuropsiquiátrico tratável por meio de um remédio com tarja preta, e a preocupação se resumiria em saber se o medicamento usado por ele é mesmo eficiente, pois poderíamos muito bem precisar de uma receita similar.

Encontramo-nos, assim, em uma espécie de "era dos transtornos" (COLLARES; MOYSÉS, 2013, p. 44) $)^{193}$, em que o lugar de ação da gestão da vida converge para o fenômeno da medicalização ${ }^{194}$, e a ortopedia social passa a ser modelada e remodelada por saberes e poderes que interferem nos detalhes e microdetalhes do corpo, incluindo aqui, tal

\footnotetext{
192 Entre outras coisas, trata-se de crianças consideradas “estranhas”, anormais, problemáticas, impulsivas, desatentas e não rentáveis.

193 "Vivemos a 'Era dos Transtornos', mas também é a 'Era das Possibilidades de Tudo Mudar'” (COLLARES; MOYSÉS, 2013, p. 61).

${ }^{194}$ Porém, é interessante observar que alguns pesquisadores, como Iriart e Iglesias-Rios (2013) e outros, em vez de falar em medicalização, preferem o termo biomedicalização, pois, segundo eles, esse último se aproximaria mais da teoria foucaultiana do biopoder e também dos trabalhos mais recentes de Rabinow (1999) e Rose (2013). Enquanto a medicalização se centraria na enfermidade, no cuidado e na reabilitação, a biomedicalização estaria enfocando a saúde como um imperativo moral, internalizando o controle, a vigilância e a transformação social. Uma das principais causas dessa mudança, como os autores reconhecem, seria uma espécie de renovação no modelo de negócios da indústria farmacêutica, que deixou de privilegiar a "educação" dos profissionais da saúde, em especial os médicos, que prescreviam seus produtos, e passou a enfatizar um modelo em que o cliente/consumidor ocupa o papel central nas campanhas de comercialização.
} 
como enfocamos, uma atuação sobre o cérebro. Com isso, a versão atual do biopoder passa a se localizar também, por exemplo, na figura da criança-aluna com Transtorno do Déficit de Atenção com Hiperatividade (TDAH) - cujo diagnóstico vem crescendo espantosamente nos últimos anos. Por não se enquadrar nos padrões de "normalidade" postulados pela sociedade e pelo saber médico, pouco a pouco, as crianças vão sendo tipificadas como portadoras de transtornos neurobiológicos, necessitando de cuidados médico-farmacológico. E pensar no processo de medicalização e/ou biomedicalização da infância, de certo modo, significa também levar em conta os processos de subjetivação que a atravessa, pois não se "trata, apenas, de produzir um melhor número de crianças, mas de gerir convenientemente essa época da vida" (FOUCAULT, 2015, p. 304).

Nesse contexto, torna-se cada vez mais comum ouvir afirmações dizendo que as "crianças não fazem mais travessuras merecedoras de um corretivo qualquer, elas padecem de um déficit de atenção objeto de resignação e boas doses de Ritalina" (LAJONQUIÈRE, 2010, p. 62). Aliás, por diminuir o "excesso" de impulsividade das crianças diagnosticadas como hiperativas, a Ritalina ganhou até mesmo o apelido de "droga da obediência"195, o que corrobora, de certa forma, a ideia de que na "era dos transtornos" as pessoas são despossuídas de si mesmas e capturadas-submetidas na teia de diagnósticos-rótulos-etiquetas, antigos e novos, cosmeticamente rejuvenescidos ou reinventados (COLLARES; MOYSÉS, 2013). Então, no lugar da enxada temos agora, entre outros corretivos bioquímicos, a "Rita"196, que em determinada dosagem vem sendo usada como tecnologia de condução dos sujeitos cerebralizados, vestindo-se da promessa de potencializar as capacidades cognitivas e, para alguns, também um importante recurso que se presta à obediência.

Nessa direção, a neuropsiquiatria, ou psiquiatria biológica, é que acaba por produzir contemporaneamente os discursos que descrevem os modos de relacionamento das crianças em sala de aula - e não apenas nesse espaço - e cunham termos que se referem a um tipo de funcionamento orgânico que pode ser farmacologicamente manipulável. Isso representa, na avaliação de Guarido (2007), uma espécie de retradução da fundação clínica médica, tal como tinha sido observada por Foucault (2014), mas agora o debate não giraria em torno do problema da alocação dos corpos dentro do espaço institucional de saúde, e sim em torno de outros elementos não menos alocáveis, especialmente modeláveis e programáveis. Trata-se,

\footnotetext{
${ }^{195}$ Disponível em: https://www.folhadelondrina.com.br/colunistas/espaco-aberto/ritalina-a-droga-da-obediencia901797.html. Acesso em: 3 mar. 2019.

196 "Rita" é um dos apelidos do fármaco Ritalina. Disponível em: http://g1.globo.com/bemestar/noticia/2016/06/como-a-guerra-fria-deu-origem-a-ritalina-a-droga-daconcentracao-infantil.html. Acesso em: 4 mar. 2019.
} 
então, de uma atuação sobre neurônios, neurotransmissores, funções bioquímicas, sinapses, hormônios etc. - objetos com os quais tanto a medicina quanto a própria escola propõem-se a interferir estabelecendo seus saberes e poderes e produzindo, de acordo com a nova lógica liberal e a demanda do mercado, o capital humano futuro.

Ainda em se tratando dos modos de relacionamento em ambiente escolar, podemos perceber uma tendência, com a popularização do vocabulário neurológico e neuropsiquiátrico, que não é tão incomum, em chamar aluno pela sua classificação diagnóstica. Temos, assim, “o estudante com TDAH do primeiro ano do ensino médio", "o disléxico do período da manhã", "o asperger que estuda à noite", "o menino de óculos que têm transtorno opositor desafiador", entre outras. Em algumas escolas, professores e coordenadores arriscam até mesmo lançar diagnósticos a respeito dos alunos que não se comportam "adequadamente", classificando-os, por vezes - de acordo com a moda -, como suspeitos de TDAH, recomendando, sempre que possível, que sejam levados pelos pais para avaliação com especialistas do cérebro e/ou da psique.

O problema, no entanto, não é negar dogmaticamente o uso dos fármacos nem demonizar qualquer tipo de diagnóstico oferecido pelos especialistas, uma vez que medicamentos e serviços de profissionais de saúde representam, em muitas situações, uma esperança para aqueles que, em última instância, desejam ter uma vida suportável. O que está em jogo são os efeitos de verdade do discurso do sujeito cerebral, principalmente a culpabilização do cérebro, e tão somente dele, pelos problemas de aprendizagem e comportamento.

Trata-se, então, de perceber a emergência de novas subjetividades, identidades e biossociabilidades. No caso específico do TDAH, esse processo fica evidenciado quando notamos que aquelas crianças que antes eram consideradas inquietas, travessas, distraídas, com necessidades diferenciadas, excessivamente alegres ou desviantes, agora são identificadas como portadoras de transtornos, e em função delas surgem novas formas de relacionar-se e sociabilizar-se: associações de pais e pacientes; cursos especiais para professores; grupos de WhatsApp ${ }^{197}$; páginas na internet voltadas para o apoio a famílias de pacientes ${ }^{198}$, entre outros.

Isso reforça o entendimento de que o controle e a regulação dos corpos, no contexto contemporâneo do biopoder, tendem a ser feitos de modo internalizado, isto é, a

\footnotetext{
${ }^{197}$ Disponível em: https://tdahdescomplicado.com/whatsapp. Acesso em: 10 mar. 2019.

${ }^{198}$ Disponível em: https://tdah.org.br/grupo-de-apoio-para-familiares-e-pessoas-com-tdah/. Acesso em: 10 mar. 2019.
} 
governamentalidade é também biomédica, podendo ser exercida por saberes especializados que monitoram, mensuram e normalizam os indivíduos e a população desde sua interioridade somática. Assim, recorrendo rapidamente a Preciado (2018), podemos pensar na Ritalina, por exemplo, e não apenas nesse medicamento, como uma ferramenta panóptica química, portátil e individual com o potencial para modificar o comportamento, programar ações e promover a obediência. A enxada e o chicote, nessa perspectiva, vão sendo aos poucos substituídos por um conveniente sistema de administração oral: "Daí em diante, a cela de prisão tornou-se o corpo do consumidor, que se vê quimicamente modificado sem poder determinar os efeitos exatos ou saber de onde eles vêm" (PRECIADO, 2018, p. 221).

No que diz respeito à biopolítica, o problema estratégico que parece estar sendo posto e que reflete nos processos de subjetivação que acontecem no ambiente educacional é o de como manipular as diferentes distribuições de normalidade, umas em relação às outras, e maximizar as mais favoráveis. E quando o assunto é a medicalização de estudantes com TDAH, por exemplo, a promessa evidenciada pelos discursos e saberes médicos, especialmente, é a produção de uma população de crianças tranquilas, atentas, sociáveis, capazes de alcançar bons resultados escolares, que não causem problemas no espaço educacional, familiar, nem nos demais ambientes sociais, ou seja, preza-se pela formação de sujeitos que sejam capazes de produzir muito mais e, ao mesmo tempo, obedientes ${ }^{199}$.

A criança-aluna diagnosticada com TDAH, ou qualquer outro modo desviante potencialmente/molecularmente corrigível, nessa lógica, exemplifica os alvos e os métodos de pastoreio contemporâneo. Mas, como o próprio Foucault (1995) assinala, só existe poder onde está presente também a possibilidade de resistir, ou seja, não há relação de poder onde as determinações estão saturadas, mas apenas quando podemos nos deslocar e, no limite, escapar.

Ao recorrer a sociologia da infância, Barbarini (2014), por exemplo, observa que as crianças rotuladas como portadoras de TDAH e incluídas em grupos de critérios de diagnósticos muitas vezes questionam, cada uma à sua própria maneira, o que lhes é imposto como problema e perguntam sobre o modo como os especialistas definem a sua maneira de ser e a sua imagem. Assim, entre as experiências da autora, nos chama atenção uma entrevista realizada com uma criança diagnosticada com TDAH que fora questionada sobre a necessidade do uso de medicamentos para controlar a hiperatividade e a falta de atenção:

\footnotetext{
${ }^{199}$ As palavras de ordem na educação é maximizar-se e obedecer pelo cérebro.
} 
Se a pessoa estiver imaginando alguma coisa... depende. Se ela tiver um trauma e não conseguir resolvê-lo, aí tem que pedir alguma ajuda, né, profissional. Mas se estiver pensando coisas boas, não tá atrapalhando nem a aula, depois qualquer coisa o professor passa pra ele, a matéria. (Menino de 13 anos, estudante de ensino fundamental II em escola municipal, entrevistado em 01/07/2013). (BARBARINI, 2014, p. 234).

Se, por um lado, o relato mostra uma estratégia no campo psi e neuro de enquadramento de sujeitos tidos como problemáticos ou desviantes, por outro, propõe também uma espécie de subversão da lógica educacional de ensinar o conteúdo a todos os alunos da mesma maneira e ao mesmo tempo, e isso pode ser observado quando a criança afirma que "se a pessoa estiver pensando coisas boas e não estiver atrapalhando a aula, depois poderia, recorrendo ao professor, aprender”. A falta de atenção, na opinião da criança, não seria um problema para ser resolvido de forma medicamentosa, pois talvez, para além de qualquer cognocentrismo e de qualquer normalização escolar, ela a interprete como uma maneira a mais de frasear em pensamentos, um modo particular de experimentar a vida e estar no mundo, ou, ainda, de encontrar-se no próprio quintal, mesmo que esteja "fora de sintonia" com a sala de aula e, aparentemente, com o seu entorno. Exemplo similar de desvio, de manter um "certo gosto por nadas", é oferecido também pelo poeta Manoel de Barros quando narra suas memórias e, coincidentemente, refere-se a um período de sua vida em que tinha a mesma idade que a criança com TDAH apresentada por Barbarini (2014).

Descobri aos 13 anos que o que me dava prazer nas leituras não era a beleza das frases, mas a doença delas.

Comuniquei ao Padre Ezequiel, um meu Preceptor, esse gosto esquisito.

Eu pensava que fosse um sujeito escaleno.

- Gostar de fazer defeito na frase é muito saudável, o Padre me disse.

Ele fez um limpamento em meus receios.

O Padre falou ainda: Manoel, isso não é doença, pode muito que você carregue para o resto da vida um certo gosto por nadas...

E se riu...

- Você não é de bugre? - e ele continuou.

— Que sim, eu respondi. Veja que bugre só pega por desvios, não anda em estradas

- Pois é nos desvios que encontramos as melhores surpresas

e os articuns maduros. Há que apenas saber errar bem o seu idioma.

Esse Padre Ezequiel foi o meu primeiro professor de agramática.

(BARROS, 1993, p. 89).

Não queremos sugerir ingenuamente que Manoel de Barros tivesse TDAH, no entanto parece interessante colocá-lo na companhia dos desviantes, como alguém que andou fora das 
estradas - ficou "pensando coisas boas" - e, com isso, sinalizar para o fato de que o desvio pode ser mais que um transtorno mental, e o medicamento seria mais que um tratamento e controle de sintomas, tratar-se-ia de dispositivos pelos quais as crianças que não aprendem na escola, não se comportam "adequadamente", que contrariam as expectativas dos professores e da sociedade e que indicam dificuldades no devir produtivo são identificadas, corrigidas e enquadradas. Logo, o desvio não é essencialmente cerebral, mas de ordem moral, e resistir, de certa forma, diz respeito a um posicionamento ético: "é a maneira como cada um se relaciona consigo mesmo, constrói para si certa 'relação' a partir da qual se autoriza a realizar determinada coisa, a fazer isto e não aquilo" (GROS, 2018, p. 33).

O desviante ou aqueles diagnosticados com algum tipo de transtorno - mesmo deixando alguns ditos "normais" com a sensação de "meio vagos" ${ }^{200}$-, a despeito de uma sociedade que valoriza a boa performance produtiva e um ideal de perfectibilidade, têm muito a nos ensinar. Apesar de fazerem parte de uma face da condição humana muitas vezes tratada como próxima demais do subsolo, representam uma potência de vida cuja resistência e dificuldade em se enquadrar já nos indicam, de antemão, os contornos de um quadro racionalmente posto - formado por cálculos econômicos que mensuram as perdas e os ganhos dos investimentos que se faz no capital humano - que de uma forma ou de outra procura normalizar e governar. O desviante, por esse ponto de vista, reflete o signo da diferença e, apesar da política da vida que planifica corpos e mentes ${ }^{201}$, nos faz lembrar, como se olhássemos em um espelho, que o normal é também ser diferente.

Pensamos, então, que desviar é uma expressão da diversidade humana - mesmo que muitas vezes o indivíduo seja medido por um termômetro excessivamente econômico - e, assim sendo, a dificuldade em "botar comida na mesa", por mais dramático que possa ser, não deveria cancelar as diferentes formas e escolhas de bem viver. E, como muito bem sabia o poeta Manoel de Barros, doutor também "varia", e medicar o subsolo pode ser uma forma de entorpecer a experiência vivida, enfim, o "Eu não posso" não é menos importante que o "Yes, we can".

Uma criança pode não suportar manter-se sentada durante o período de aula; um adolescente pode não conseguir se concentrar sequer cinco minutos nos estudos; uma travesti pode preferir permanecer em casa, dormindo incessantemente, do que enfrentar a procura por um trabalho vestindo trajes

\footnotetext{
${ }^{200}$ Expressão usada por Manoel de Barros para se referir a seu pai.

${ }^{201}$ Não pretendemos aqui, ao falar sobre corpo e mente, sugerir nenhuma forma de dualismo. Estamos apenas usando essas palavras para afirmar os investimentos do poder sobre a vida, os quais atentam tanto para a anatomia bruta dos corpos quanto para suas sutilezas.
} 
que a fazem se sentir despersonalizada; um homem de meia-idade pode preferir tomar pílulas para dormir a ter que enfrentar as noites em claro se martirizando por não conseguir sair de seu trabalho atual, que julga tão penoso; uma mulher pode não conseguir mais se comprometer com o trabalho de educadora, pois já se sente absolutamente incapaz de construir uma relação diferente na escola que trabalha. Desatenção, depressão, ansiedade, burnout, pânico, transtornos, síndromes, doenças. Expressões concretas do impacto violento de nossas formas de viver sobre corpos e subjetividades. (COLLARES; MOYSÉS, 2013, p. 13).

Nessa direção, seja por meio de investimentos que fazem uso ou prometem usar técnicas neuroeducativas, ou pelo processo de (bio)medicalização da educação, a expressão de ordem, ainda que obscura, parece ser "conduzir pelo cérebro". Isso acontece, como indicamos, por meio de um discurso que incita o aprimoramento e incremento cognitivo daqueles que devem se tornar empresários de si mesmos - homo oeconomicus cerebralizado - e pelos investimentos na correção, obediência e normalização dos que são considerados “anômalos", isto é, desatentos, hiperativos, impulsivos, resistentes, fraseadores, devaneadores, problemáticos, enfim, indivíduos cujo comportamento ameaçam certa lógica neoliberal de produtividade. Então, a neuroeducação e a medicalização, segundo o que pensamos, constituem dispositivos de subjetivação e inserem-se na ação positiva, transformadora e potencializadora do poder, atualizam, contemporaneamente, a governamentalidade biopolítica, a qual é feita por meio de investimentos naquilo que existe de mais sútil em nossa corporeidade.

\subsection{INSINUAÇÕES DE RESISTÊNCIA}

Em complemento à reflexão que fizemos a respeito da biopolítica contemporânea, principalmente no que foi aventado sobre os estados mentais e/ou cerebrais e o destaque que vêm recebendo na regulação de nossas condutas, pretendemos, neste último tópico, discutir um pouco mais sobre o tema da resistência. Acreditamos que, diante de um processo de assujeitamento e governo da vida, alimentado por uma compreensão de nós mesmos como sujeitos cerebrais e por uma política de aprimoramento que leva em consideração a nossa estrutura encefálica, é importante destacar também quais seriam as possíveis forças vitais que de certo modo estariam na contramão dessa lógica de condução biopolítica e, assim, verificar se há mesmo algo de verdadeiro na afirmação de que "quando, como diz o rap, 'tá tudo dominado', no extremo da linha se insinua uma reviravolta", ou se "Aquilo que parecia 
submetido, controlado, dominado, isto é, a vida, revela, no processo mesmo de expropriação, sua potência indomável" (PELBART, 2007, p. 58).

Assim, arriscando um pouco, vamos sugerir hipoteticamente que a possibilidade dessa reviravolta da vida, ou pelo menos alguns dos seus sinais, pode ser buscada em duas vias principais. A primeira corresponde a um desencadeamento mais ou menos voluntário, ou mesmo involuntário, de certas forças vitais em uma espécie de negação das formas planificadas de vida. Trata-se, por exemplo, de situações em que a pessoa, de uma maneira um tanto inusitada - seja por escolha própria ou "desvio" somático -, acaba por dizer "não" ou "preferiria não" a um modo específico de ser ou de fazer, ou quando emergem movimentos que desafiam um jeito próprio de condução da vida - de maneira radical, é o que parece acontecer no emblemático conto de Bartley, escrito por Melville (2005)202. Também incluímos aqui aquelas atitudes, às avessas, bastante apreciadas na literatura, na religião, na política e nas ciências e que não são exclusivas do mundo ficcional, sendo possíveis de acontecer mesmo em nosso cotidiano: "Queriam-me casado, fútil, cotidiano, tributável? [...] o contrário de qualquer coisa? Se eu fosse outra pessoa fazia-lhes, a todos, a vontade. Assim como sou tenham paciência! Vão para o diabo sem mim, ou deixem-me ir sozinho para o diabo!" (PESSOA, 2007, p. 242), e ainda: "Não me trato e nunca me tratei, embora respeite a medicina e os médicos. [...] se não quero me tratar é apenas de raiva. Certamente não compreendeis isto" (Dostoievski, 2000, p. 15).

Ao comentar sobre o tema da suscetibilidade, Rose (2013, p. 139) nos apresenta ainda o caso de Gino, um jovem que é biologicamente predisposto a sofrer de "distrofia muscular do tipo cinturas" e que, diferente de seu irmão, recusa subjetivar a si mesmo naquilo que diz respeito a sua doença e luta para desfazer-se de uma determinação que pesa sobre ele. Em vez de agir como um doente "em potencial", ou um "pré-doente", tal como sugerem os peritos da vida em acordo com a racionalidade biopolítica, prefere beber vinho e assistir a Marseille no bar local: "Sua recalcitração parece impossível de explicar; ele é não somente o alvo de numerosas tentativas por parte de parentes, de amigos e de outros de fazê-lo agir responsavelmente, mas ele recusa-se a justificar-se quando confrontando pelos sociólogos" (ROSE, 2013, p. 139). Em outra linha, Preciado (2018) nos relata também a tensão de suas próprias experiências ao mostrar a desconstrução de seu gênero e, em certa medida, a

\footnotetext{
${ }^{202}$ Nesse conto, tratado em Agamben (2015) e Deleuze (2011), é narrada a história de um “estranho escriturário que, após um período inicial de muito trabalho comparando textos judiciais, um dia recusa-se a realizar uma tarefa dizendo "Eu preferiria não". Frase que depois, transformada em fórmula, passa a contaminar todas as atividades no escritório em que trabalha, local onde o personagem resolve se instalar e viver.
} 
transformação do seu próprio corpo em um laboratório de desterritorialização da identidade, principalmente quando faz com que o seu "ser mulher" seja deslocado - como um nômade viajando em meio a hormônios - para o campo do não ser (mulher), ou ser outro.

Pensamos que esses tipos de manifestações, muitas vezes tratados como desviantes ou "anômalos", sinalizam aquilo que Agamben (2015), ao resgatar Aristóteles, chama de "potência de não", que se refere à possibilidade de toda potência de ser ou de fazer algo ser também uma "potência de não ser ou de não fazer" (AGAMBEN, 2015, p. 14), ou ainda, seguindo a trilha de Foucault (2000), que diga respeito às atitudes de resistência à política do pastoreio, correspondendo a certa escolha do indivíduo - mesmo que mínima - em não ser governado de determinada maneira e segundo um preço específico. Em suma, os signos desviantes agem ${ }^{203}$, ou pelo menos assim nos parece, como se estivessem forçando a abertura de uma janela na qual a visão que se tem, ou que se poderia ter, é a do horizonte contingente da vida, ou daquilo que entrevemos como sendo o território da liberdade humana. Assim, em meio a inúmeras atitudes consideradas contrárias e/ou "anômalas", há as que se revestem de potencial de "escape", aquelas que indicam táticas de movimentação e drible ou, de certa maneira, que flertam com o "não ser assim", o "não fazer", "ser outro", “fazer diferente” ou, em última instância, sinalizam o "resistir".

A segunda via, de outro lado, não é necessariamente voluntária nem contradiz a primeira, corresponde a uma ação e reação da vida mesma, é uma forma "selvagem" e catastrófica de manifestação vital, diz respeito a uma potência "impessoal”. Aqui é o próprio corpo, seus órgãos, moléculas, genes, neurônios e bioquímica que parecem "recusar" as formas de planificação do poder e do saber ao mesmo tempo em que desferem golpes na política da vida. Quem fala "não" não é propriamente a pessoa, sua face-sujeito, mas, seguindo Canguilhem (2006), principalmente quando diz que a saúde é a vida no silêncio dos órgãos, aqui é a vida em seu ruído.

Se o poder sobre a vida, como assinala Foucault (2014), desde a modernidade é exercido de maneira positiva e tende a potencializar e governar os corpos, aprimorando-os, nessa segunda via a vida, ela mesma enquanto fenômeno puramente biológico e na contramão de uma política de aprimoramento, mostra-se frágil - mas não menos potente -, imprevisível e ingovernável. Ela nos dá o recado de que, embora o ser humano possa brincar de ser Deus, ele não o é. E, retomando a imagem mítica que propusemos no início deste trabalho, ainda que tenhamos "recebido" de Prometeu a faísca roubada dos deuses, e ela reluza intensamente

\footnotetext{
${ }^{203}$ Essa ação, contrariando os ditames de uma cultura hedonista, mostra-se bastante dramática.
} 
nos dias de hoje graças ao desenvolvimento tecnocientífico, nem por isso chegamos a habitar o Olimpo. E, em uma reviravolta, como que numa cobrança imposta pelos próprios deuses, esse recado da vida é transmitido por uma espécie de sequestro do ser vivente - é como se o sujeito fosse roubado dele mesmo, desde dentro (de sua faísca), e não fosse mais devolvido. Malabou (2014) trata disso em termos de uma "ontologia do acidente", fala - como já indicamos em outro momento - de uma dimensão explosiva, plástica e destrutiva da vida.

\begin{abstract}
Alguma coisa se mostra por ocasião do dano, do corte, alguma coisa a que a plasticidade normal, criadora, não dá acesso nem corpo: a deserção da subjetividade, o afastamento do indivíduo que se torna estrangeiro para si mesmo, não reconhece mais ninguém, não reconhece mais a si mesmo, não se lembra mais. Tais seres impõem assim uma nova forma à antiga, sem mediação nem transição nem cola nem compatibilidade, hoje contra ontem, cruamente, à queima roupa. [...] se diz: nunca imaginei que ele, ou ela, "viraria isso". Rasgão vital e desvio ameaçador que abrem outra via, inesperada, imprevisível e sombria. (MALABOU, 2014, p. 14).
\end{abstract}

Exemplos dessa dimensão ontológica, desse "rasgão vital", podem ser encontrados, como a própria autora indica, em trabalhos de neurologia, em especial nos que tratam da formação da identidade de sobreviventes, ou identidade cérebro-lesada. Diz respeito a acontecimentos e histórias particulares envolvendo certo rompimento abrupto do indivíduo com ele mesmo, uma espécie de corte ontológico, algo a que todos estaríamos sujeitos e que poderia ser causado por um acidente qualquer, como aqueles relatados por Damásio (1996), começando pela dramática situação de Gage, citada anteriormente, depois também pela descrição de Elliot, que por causa de uma patologia neurológica, um meningioma, passa a viver ao sabor de um novo ritmo: "Mulher, filhos e amigos não conseguiam compreender como uma pessoa instruída e devidamente prevenida podia agir de forma tão insensata" (DAMÁSIO, 1996, p. 61), até chegar aos casos de anosognosia - uma das patologias neuropsicológicas mais bizarras -, que se expressa na incapacidade de uma pessoa estar consciente de sua própria doença:

\footnotetext{
Imagine uma vítima de um acidente vascular cerebral, totalmente paralisada do lado esquerdo do corpo, incapaz de mover a mão e o braço, a perna e o pé [...]. E agora imagine essa mesma pessoa alheia a todo esse problema [...], respondendo à pergunta "Como é que se sente?" com um sincero "Ótimo". (DAMÁSIO, 1996, p. 87).
}

Apesar de existirem vários outros exemplos, e não sendo nossa intenção nos determos neles, vale lembrar, somente a título de sugestão, que Oliver Sacks (1997) e Andreasen 
(2003), além do próprio Damásio (1996), conseguem descrever alguns acontecimentos assim de forma bastante bela e sensível, nos envolvendo em muitos desses dramas. Somos colocados diante de pessoas que se tornaram repentinamente outras, ou já nasceram, considerando o que se esperava delas, ontologicamente “diferentes". É interessante notar, porém, que não são casos distantes, muitos deles até mesmo sendo possíveis de acometer a um de nós, ou quando diz respeito a um avô ou avó que na velhice passa a sofrer de mal de Alzheimer e não reconhece mais o rosto do filho e dos netos, nem se lembra, minutos depois de ter se alimentando, de que houvera feito isso, um amigo que sofreu acidente vascular cerebral (AVC) e que então passa a dizer e fazer coisas estranhas a seus costumes, ou mesmo um filho que tendo nascido com algum detalhe neurológico "atípico" mostra-se ausente na completude da presença dos pais, enfim, são várias as histórias que retratam aquilo que Malabou (2014) aponta como sendo uma explosão plástica ontológica e existencial da subjetividade e da identidade, ou simplesmente um ruído em uma forma de vida que é difícil de passar despercebido pelos olhos e ouvidos daqueles que se dizem normais.

Temos, então, resumidamente, essas duas possibilidades de reflexão: uma em que a face-sujeito resiste e diz "não" para determinado modo de ser e fazer, e outra em que não se verifica completamente essa mesma face, pois o que existia já fora implodido, e quem diz "não", aquele que emite o ruído é o próprio corpo $^{204}$ e seus detalhes - moléculas, genes e neurônios -, constituindo um tipo de "resistência" que, no limite, beira a um homicídio ontológico. Ademais, é importante notar também que a possibilidade de ser ou não ser, fazer ou não fazer, ser outro e fazer diferente, que caracterizaria a primeira via, comporta em si mesma uma dimensão ética, diz respeito à capacidade que o indivíduo tem de realizar ou não uma ação qualquer - podendo incluir aqui também o olhar do outro -, já na segunda via a ética emerge essencialmente no registro do outro, é uma questão que se abre totalmente para a alteridade. Assim, diante de uma governamentalidade da vida que vem acontecendo por intermédio de um governo do nosso noûs, daquilo que afirmamos como sendo a dimensão mais sutil de nossa corporeidade, o que esperamos, então, é a possibilidade de um horizonte em que a vida possa se insinuar como resistência.

\subsection{1 "Sobras" e pequenas resistências}

\footnotetext{
${ }^{204}$ Isso não significa, porém, que a face sujeito seja destituída de corpo.
} 
Admitindo, pois, a primeira via, a ação de resistência ao poder sobre a vida se expressa, por exemplo, em atitudes - entre outras - como aquelas que Agamben (2009), inspirado em Nietzsche, chama de "intempestivas", ou Foucault (2000), inspirado em Kant, denomina de "críticas". Essas ações estão presentes em um certo esforço que o indivíduo é capaz de fazer no intuito de não ser devorado pelo seu próprio tempo, refere-se à negação de uma existência em grande parte submissa ou, ainda, reflete-se em uma disposição e coragem de espírito para produzir seus próprios devires. Trata-se de resistir levando em consideração um cuidado e desapego de si que situa o indivíduo como objeto de experimentação e crítica; é também uma possibilidade ético-política de estabelecer relações consigo e com outros por meio de práticas que ocasionem novas maneiras de ser e viver.

Assim, se a governamentalidade biopolítica, como sugerimos, vem acontecendo prioritariamente mediante investimentos que potencializam, modelam e remodelam os estados mentais/cerebrais dos indivíduos - já que o biopoder é positivo, transformador e produtivo -, e em virtude desse governo o homem cada vez mais "crê-se capaz de tudo e repete o seu jovial 'não há problema' e o seu irresponsável 'pode fazer-se”' (AGAMBEN, 2010, p. 58), então resistir, ser intempestivo e crítico, de alguma maneira, talvez diga respeito ao reconhecimento e à readmissão, pelo próprio indivíduo, e pelo outro, de certa impotência da vida e corresponda, como em uma relação de contraste, a desmistificação dos recursos raros, do "a mais" cognitivo, do cérebro "turbinado" e do corpo "sarado", enfim, do capital humano frente a realidade de que podemos ou não podemos fazer.

Essa readmissão, seguindo a trilha de Agamben (2009), principalmente quando discute sobre "o que é o contemporâneo", talvez esteja relacionada a uma tomada de decisão do indivíduo - feita de forma corajosa - em não se deixar cegar pelas luzes do seu próprio século, mas nelas "entrever [...] a parte da sombra, a sua íntima obscuridade" (AGAMBEN, 2009, p. 64). Ora, se o facho de luz do nosso século, tal como mostrado até aqui, está reluzindo nos sujeitos de desempenho, nos que chegam primeiro, nos mais produtivos, mais criativos, com mais memória e mais inteligência, haja vista todos os investimentos e tecnologias que são desenvolvidas para aprimorá-los, melhorar seu cérebro e mudá-lo em seus detalhes, então os signos de resistência, em contrapartida, talvez devam ser procurados em tudo aquilo que é posto à margem, no que "sobra": os capitais humanos avariados, os que produzem pouco, os que não alcançam as melhores notas e os melhores empregos, os que dizem não ("não quero ser doutor"205, "não quero agir como um pré-doente"), os que têm 
pouca memória, desatentos, hiperativos, enfim, todos aqueles que, embora capitalizáveis, dificilmente farão parte do topo da lista dos recursos raros - uma vez que são tidos como corpos e cérebros desviantes. Assim, pensar em resistência, de certo modo, envolve uma (re)apropriação de elementos humanos que "sobram", e devemos considerar que a sobra, atualmente, já não se justifica pelas características que são exteriores a nós, unicamente, mas por certas propriedades que especialistas da vida afirmam estar em desequilíbrio no interior de nosso crânio, de nossas moléculas, invadindo a bioquímica, neuroquímica, genes, hormônios etc.

O insurgente de hoje e dos próximos anos pode ser também um sujeito cerebral, hormonal e molecular, alguém que por causa do seu corpo-cérebro pensa e vive "fora" da normalidade. Afinal, em um mundo quase que totalmente cartografado, admitir como lição e exemplo vital o que é inventado ou posto "fora" talvez seja uma maneira de apreender nossas sombras em meio às luzes que iluminam esse século. Na mesma direção de uma subjetividade que não se define como homem ou mulher, é (está) uma subjetividade insurgente, como dá a entender Preciado (2018) ${ }^{206}$, parece-nos que um sujeito e cérebro desviante, ao afirmar sua diferença e seu "não", ou apenas sua forma de ser, talvez esteja a insurgir.

Não sem ressalvas ${ }^{207}$, Ortega (2008b) aponta nessa mesma direção quando comenta sobre o movimento de pessoas que se denominam neurodiversas, ou neuroatípicas. Trata-se de grupos de autistas classificados como de "alto funcionamento", ou com síndrome de Asperger, os quais defendem que o que a maioria das pessoas denomina como doença (autismo) na verdade não é, mas constitui parte do que eles mesmos são, portanto, assim como outras diferenças (raciais, sexuais, entre outras), em vez de serem "simplesmente" curados, reivindicam respeito ao seu modo particular de ser. Dessa maneira, apesar de reconhecidos como entidade nosológica (DSM-III), acabam por disputar "belicamente" um estatuto ontológico - diferentes - e incluem em suas manifestações, por exemplo, até mesmo

\footnotetext{
${ }^{205}$ Não significa, todavia, que alguém que teve seu arcabouço de conhecimento formado dentro da governamentalidade biopolítica não possa resistir. O que queremos aqui é apenas enfatizar que alguém, por livre vontade e independentemente das próprias condições oferecidas, pode escolher não fazer ou ser outra coisa diferente do the é exigido (lembrando assim o caso do poeta Manoel de Barros).

206 "Não se trata de passar de mulher para homem ou de homem para mulher, mas de contaminar as bases moleculares da produção da diferença sexual, entendendo que esses dois estados do ser, homem e mulher, existem apenas como 'ficções políticas', como efeitos somáticos dos processos técnicos de normatização" (PRECIADO, 2018, p. 153).

${ }^{207}$ Ortega (2008b) adverte que os movimentos de neurodiversidade, ao colocarem o direito a diferença do lado biológico, por exemplo, correm o risco de cair em uma política identitária calcada em predicados naturais que conduzem a uma redução da pluralidade à identidade, homogeneizando as diferenças e suprimindo a singularidade dentro do próprio movimento. Diz, então, que é necessário amadurecimento e autocrítica, no entanto concorda que, se os dispositivos de saber-poder são mecanismos de assujeitamento, eles também abrem a possibilidade de resistência, e esses movimentos, de uma forma ou de outra, representariam isso.
} 
o "Dia do Orgulho Autista"208. Esse movimento, bem como outros que estão a emergir nas sombras e se afirmam enquanto identidades cerebrais, vem multiplicando as lutas cotidianas pelo direito de aprender de um jeito próprio, exigindo o direito ao seu ritmo, a diferença na igualdade e a igualdade na diferença, corroborando o que é dito por Santos (1999, p. 62): "Temos o direito a ser iguais sempre que a diferença nos inferioriza; temos o direito a ser diferentes sempre que a igualdade nos descaracteriza".

Ainda, nessa lógica, por meio de pequenos gestos ${ }^{209}$, crianças diagnosticadas com TDAH escapam até mesmo ao efeito dos medicamentos, como muito bem aponta Barbarini (2016) ao descrever cuidadosamente alguns casos, entre os quais o de Danilo ${ }^{210}$, um estudante que ao ser encaminho à diretoria da escola, e tendo tomado sua dose diária de Ritalina, não deixa de conversar "inapropriadamente" nem de se comportar de maneira "inadequada". Danilo inquieta os observadores e os faz tremer, “[...] escancara o que tememos e contra o que lutamos todos os dias: a impotência do professor frente aos saberes técnicos científicos; o erro como humanidade (e não a perfeição como sobre-humanidade). [...] ele coloca em questão todo um modo contemporâneo de aprender de se relacionar, enfim, viver" (BARBARINI, 2016, p. 143).

Esses indivíduos, partícipes do que está "fora" 211 , ou essas "sobras" da política da vida que fazem "tremer" aqueles que se dizem normais, talvez devessem ser compreendidos no registro daquilo que Certeau (1994) denomina de arte da solidariedade ou, ainda, de livre produção com “sucata". Trata-se, nesse caso, em Certeau (1994), do reconhecimento de certo potencial subversivo em meio aos trabalhadores das fábricas, o qual emerge das relações desses sujeitos com as sobras da produção liberal.

Certeau (1994) afirma que, nos lugares em que reina a máquina à qual deve servir, o operário algumas vezes "trapaceia" - mesmo que os quadros o penalizem ou "fechem os olhos" para não vê-lo - pelo simples prazer de inventar produtos gratuitos destinados somente a significar por sua obra um saber-fazer pessoal e a responder por despesa a solidariedade operária e familiar. Nessas situações, o trabalhador converte o tempo da máquina em pequenas produções não capitalizáveis, extraindo-lhes apenas satisfação e gozo. Para isso, o

\footnotetext{
${ }^{208}$ Inspirado no "Dia do Orgulho Gay", o "Dia do Orgulho Autista" ocorre em 18 de junho.

${ }^{209}$ Trata-se mesmo de pequenos gestos, não é uma ação organizada - como no caso daqueles diagnosticados com síndrome de Asperger. Diante das manobras de uma governamentalidade biopolítica que atua sobre o corpocérebro das crianças, a capacidade de resistir é muito pequena, no entanto ela existe, como nos aponta a sociologia da infância, mas não apenas ela, a própria experiência do dia a dia também nos revela isso, principalmente quando olhamos para nossos filhos.

${ }^{210}$ Nome fictício, para preservar a identidade da criança.

${ }^{211}$ Mas, como toda epiderme, ao mesmo tempo em que está fora também está dentro.
} 
trabalhador se utiliza de materiais dentro do espaço da fábrica que são considerados "sobras" e, a despeito dos recursos raros, ele sabe muito bem que aquilo que sobra não tem valor algum (ou pouquíssimo) para a racionalidade econômica. Desse modo, o operário não subtrai necessariamente bens, já que se serve do que foi posto "fora", mas driblando o tempo e o espaço da produção do capital consegue recuperar algo que lhe é valioso, a saber, os instantes de sua própria vida.

Esse fenômeno, em princípio fabril, teria um grande potencial de generalização, pois nos espaços em que se insinua há "um estilo de resistência moral, isto é, uma economia do 'dom' (de generosidades como revanche), uma estética de 'golpes' (de operações de artistas) e uma ética da tenacidade (mil maneiras de negar a ordem estabelecida, o estatuto de lei, de sentido ou fatalidade)" (CERTEAU, 1994, p. 88-89). Além disso, seria uma maneira de reivindicar territórios existenciais alternativos, diferentes dos que são ofertados pelo capital.

Considerando, então, que a máquina produtiva, ou o próprio capital, é o indivíduo - o seu corpo-hardware, e atualmente, mais ainda, o seu corpo-software, ou sua flexibilidade maquínica -, devemos acreditar que aquilo que não é valorizado como recurso raro pela racionalidade econômica, como o desejo de "frasear" mais do que o de ser doutor (em virtude, quem sabe, de algum “desequilíbrio neuroquímico"), talvez sirva de modelo e inspiração para compreender a insurgência de certa potência da vida, ou pelo menos para entrever manifestações intempestivas de uma face-sujeito. Afinal, no contexto de um capitalismo cultural que expropria e revende modos de vida, não haveria também uma tendência, por parte daqueles que são deixados de "fora", os excluídos, de "usar a sua própria vida na sua precariedade de subsistência, como um vetor de autovalorização?” (PELBART, 2009, p. 37).

Apenas para sinalizar, pensamos que a resposta para essa pergunta deve ser afirmativa, no entanto a afirmação não pode ser do tipo "Yes, we can", nos mesmos moldes dos discursos motivacionais que incitam a ótima performance produtiva e aparecem no contexto da governamentalidade neoliberal, mas uma resposta em que se admita, afirmativamente, a "sobra", a ineficiência, o cérebro avariado, a impotência, ou toda a potência do "não", ou ainda uma em que caibam Meninos Maluquinhos, Mafaldas, Xavecos, Emílias e todos aqueles que resistem e insistem em desobedecer, questionar, devanear, "passear pela lua", e que sonham e buscam novas maneiras de ser e estar no mundo.

\subsubsection{Uma resistência explosiva}


Para encerrar, vamos apontar rapidamente um tipo de resistência imposta pela vida mesma, uma força incontrolável e ingovernável que se inscreve sorrateiramente na própria estrutura do vivente e tem o poder de mudar a sua forma e o seu modo de ser. Trata-se de uma resistência ao biopoder que se dá no registro da vida enquanto fenômeno essencialmente biológico e, em algumas situações, apresenta-se como catástrofe e monstruosidade: "Uma forma nascida do acidente, nascida por acidente, uma espécie de acidente. Uma estranha raça [...]. Um ser novo vem ao mundo uma segunda vez, vindo de uma vala profunda aberta na biografia” (MALABOU, 2014, p. 11).

Como procuramos mostrar, muitas das técnicas de subjetivação que foram propostas nas últimas décadas giram em torno da figura do sujeito cerebral (ou self neuroquímico) e, de certa forma, prestam-se a uma atualização da governamentalidade da vida, ao mesmo tempo em que alimentam os ideais de uma economia neoliberal, principalmente quando diz respeito aos incentivos à produção de "bons equipamentos" humanos - agora traduzíveis também como "cérebros melhorados" - e à inserção destes na lógica do homo oeconomicus. Essas técnicas, de modo geral, fundamentam-se em conceitos extraídos das neurociências (sinapses, neurotransmissores, localizações cerebrais, neurogênese etc.), sendo que um dos principais, ou o principal, como apontamos, vem a ser o de plasticidade, ou neuroplasticidade (ORTEGA, 2009a). Afirma-se, genericamente, que o cérebro é um sistema capaz de desenvolver alterações estruturais em resposta às diferentes condições a que é exposto e em virtude da repetição de estímulos ${ }^{212}$ (hábitos). Com isso, na maioria das vezes, admite-se que esse órgão é modulável e, como a argila, o mármore ou mesmo um software computacional (formado a base de uma rede neural), pode ser esculpido, remodelado, programado e potencializado. Daí a nossa afirmação anterior, por exemplo, de que as técnicas neuroeducativas estariam sendo projetadas biopoliticamente para agir não apenas nas conexões neurais que o cérebro já possui, mas nas conectividades que ele ainda não tem e que, no futuro, pode vir a ter. Em outros termos, ao incorporar a noção de plasticidade e/ou neuroplasticidade, a governamentalidade biopolítica estaria sinalizando o agenciamento do ser não apenas em sua atualidade, mas em seu devir.

\footnotetext{
${ }^{212}$ De acordo com a lei de Hebb, se dois neurônios estão ativados aproximadamente ao mesmo tempo, suas conexões são fortalecidas. A ideia é de que quanto mais forte for a contingência entre a ativação neuronal e certo tipo de estimulação, quanto maior será a probabilidade que que as redes neurais relevantes desencadeiem impulsos quando o estímulo retorna. Isso explicaria, por exemplo, por que a prática ou a revisão dificultam o enfraquecimento das sinapses (como no esquecimento). Disponível em: https://pt.sainteanastasie.org/articles/neurociencias/ley-de-hebb-la-base-neuropsicolgica-del-aprendizaje.html. Acesso em: 26 abr. 2019.
} 
No entanto, ao explorar detalhadamente esse conceito, recorrendo a filósofos como Spinoza, Hegel e Derrida, e a neurocientistas como António Damásio e Jean-Pierre Changeux, Malabou (2014) parece ter chegado à conclusão de que, embora a ideia de plasticidade seja compatível com a lógica neoliberal, uma vez que é com base nisso que se pode falar em "cérebros melhores", normalização ou em produção e potencialização de "capital mental" podendo incluir aqui os discursos da neuroascese e de neuroaprimoramento farmacológico e neuroeducação -, é possível também situá-la em um quadro diferente daquele que vem sendo comumente inserida, isto é, o quadro de uma crítica ao biopoder e nas proximidades de uma dimensão ingovernável da vida, lá onde o escultor trabalha por aniquilamentos.

Para isso, Malabou (2014, p. 12) observa que o termo plasticidade, apesar de ter uma conotação positiva na ciência, medicina, arte, ou mesmo no domínio da educação, e mesmo que "seja concebida como uma espécie de trabalho de escultura natural que forma nossa identidade" - podendo essa identidade ser modelada artificialmente por meio de bioquímicos, por exemplo, ou por estímulos envolvendo o hábito -, resta-lhe ainda algo de destrutivo, explosivo e desorganizador que precisaria ser devidamente compreendido: "A ninguém ocorreria a ideia de entender sob a fórmula 'plasticidade cerebral', por exemplo, o trabalho negativo da destruição (destruição que opera após tantas lesões cerebrais e traumatismos diversos" (MALABOU, 2014, p. 12). Assim, se ao recorrer à noção de plasticidade é possível pensar em uma articulação causal entre "isto é” e um certo "por vir", aparentemente previsível e governável, haveria também uma abertura "plástica" em que se inscreveria uma dimensão incerta e destrutiva da vida: "Ninguém pensa espontaneamente numa arte plástica da destruição. No entanto, esta também configura. Uma cara quebrada é ainda um rosto, um coto é uma forma, uma psique traumatizada permanece uma psique. A destruição tem seus cinzéis de escultor" (MALABOU, 2014, p. 13).

Com o objetivo de mostrar esse porvir incerto, incontrolável e explosivo, Malabou (2014) acaba, então, por distinguir ao menos três significados do termo plasticidade: tomar forma, dar forma e explodir a forma ${ }^{213}$. A intenção da pensadora ao esboçar os dois primeiros significados, segundo Freitas (2016), é o de expor o uso "desviado" do termo plasticidade por intermédio de seu suposto sinônimo, a noção de flexibilidade ${ }^{214}$ : "A flexibilidade seria uma

\footnotetext{
${ }^{213} \mathrm{O}$ primeiro diz respeito à capacidade de alguns materiais, como a argila, a madeira, o mármore e o próprio cérebro, de receber forma; o segundo designa o poder de dar forma, como no caso de um cirurgião plástico que modifica um rosto, o escultor que trabalha o mármore, ou ainda um produto bioquímico que altera nossos afetos e potencializa a memória; e o último, por sua vez, refere-se à deflagração ou explosão de toda forma, como no caso de um acidente cerebral que transforma uma identidade em um devir outro.
} 
forma reconhecível e identificável da plasticidade, um avatar ideológico encarnado na lógica que nos impulsiona para o mundo das representações mercantis e empresariais" (FREITAS, 2016, p. 249). Por isso, talvez, muitos dos termos e expressões usadas no discurso empresarial coincidirem, contemporaneamente, com a qualidade daquilo que é flexível: organização de fluxos de comunicação lateral, multitarefas, cocriação entre múltiplos indivíduos, produção localizada e discreta, além de uma ênfase em qualidades humanas "plásticas" como reação à mudança, capacidade de inovação, proatividade, adaptabilidade, entre outras ${ }^{215}$.

De certo modo, todos aqueles incentivos à formação de capital humano aqui anteriormente discutidos, que vêm fazendo alusão ao aprimoramento cerebral, na verdade servem para reforçar uma noção de flexibilidade que é ela mesma neoliberal. Por um lado, há uma clara intimidade entre o discurso neoliberal e o modelo flexível do cérebro e, por outro, a neurocultura e a própria noção de sujeito cerebral mostram-se carregados de um pensamento neoliberal. Ademais, e em parte, o próprio neoliberalismo parece constituir uma economia da flexibilidade. Assim, ao incluir o uso do termo plasticidade - significando "receber forma", por exemplo -, e junto as técnicas contemporâneas de subjetivação, o indivíduo e a população estariam sendo situados em uma ética normativa e econômica disfarçada de um "cuidado de si”, ou de um cuidado do outro, via cérebro, mas que em última instância configuraria uma estratégia biopolítica de expropriação do potencial plástico dos indivíduos, ou de sua flexibilidade, alinhado, é claro, ao seu próprio governo, tal como procuramos mostrar.

Nessa direção, Malabou (2014) propõe uma terceira noção de plasticidade e/ou neuroplasticidade estranha ao registro da flexibilidade, da passividade em ser "dobrado" ou do poder de voltar a estados anteriores de funcionalidade, sugerindo, então, a ideia de uma "explosão plástica" e uma insubmissão destrutiva da vida diante dos poderes e técnicas que normalizam e subjetivam. Se, como nos aponta Arendt (2010), existe um impulso primitivo no homem que o impele a escapar de sua condição humana e o faz sonhar com a conquista de espaços distantes, ou mesmo com a manipulação daqueles que lhe são internos, há, em contrapartida, um princípio vital de instabilidade capaz de eliminar o que já fora conquistado e/ou biopoliticamente manipulado, algo tão poderoso que pode transformar o indivíduo em um estrangeiro de si sem precisar sair de seu espaço.

\footnotetext{
${ }^{214}$ Dizendo muito rapidamente, a flexibilidade designa a possibilidade de um ente ser transformado sem ser destruído ou a uma volta aos estados anteriores de sua funcionalidade.

$215 \quad$ Disponível em: https://www.academia.edu/7622841/The_Plastic_Brain_Neoliberalism_and_the_Neuronal_Self. Acesso em: 30 abr. 2019.
} 
Esse princípio, segundo a autora, se faz presente principalmente nas ontologias acidentadas, cindidas, nos doentes de Alzheimer, nos cérebros-lesados, em traumatismos de guerra, vítimas de catástrofes naturais ou políticas, enfim, em todas aquelas figuras que de um modo ou de outro somam-se às casuísticas de abalo neurológico. Trata-se de figuras como as descritas por Damásio (1996), Sacks (1997), Andreasen (2003) e outros, por meio das quais as transformações radicais e sem volta da identidade claramente são vistas: um escritor que não se lembra mais de seus livros, que não se lembra mais de si mesmo, que está morto sem estar morto, ou um corretor de imóveis que, apesar de manter a sua capacidade de raciocínio intacta, não consegue mais tomar decisões por causa de uma apatia e insensibilidade afetiva provocada por um tumor cerebral, entre outros. Mas como muito bem assinala Malabou (2014), um tal princípio de explosão "plástica" talvez esteja inscrito no registro mesmo das leis cerebrais, nas identidades consideradas "normais" que desde sempre são entidades mutáveis e transformáveis, sempre capazes de dar uma guinada ou dizer adeus a si mesmas.

Nessa perspectiva, paralelamente ao uso positivo do termo plasticidade que afirma um trabalho de escultura da identidade, agora cerebralizada, e que visivelmente é explorada pelo neoliberalismo, haveria também uma plasticidade ontológica negativa capaz de produzir uma existência outra e sem relação com a anterior. O reconhecimento dessa dimensão negativa da plasticidade é o que nos permitiria, segundo Malabou (2014), radicalizar a desconstrução da subjetividade e imprimir-lhe uma nova virada.

Esse reconhecimento revela que uma potência de aniquilamento se esconde no coração da própria constituição da identidade, uma frieza virtual que não é o apanágio apenas dos cérebros-lesados, dos esquizofrênicos ou dos serial Killers, mas a assinatura de uma lei do ser que parece sempre a ponto de abandonar a si mesmo, de se esquivar de si mesmo. (MALABOU, 2014, p. $35)$.

Trata-se, desse modo, de perceber que a mudança causada por um acidente ontológico é ela mesma constitutiva do próprio sujeito, isto é, a capacidade de se transformar sob o efeito da destruição é um possível, uma forma existencial. Se existem forças que subjetivam, ou técnicas que produzem, potencializam e conduzem o capital humano, via cérebro, também há alguma coisa de humano que se manifesta na deserção da subjetividade e escapa às formas tradicionais da governamentalidade. Esse algo que muitas vezes se manifesta no ápice mesmo da existência e captura indistintamente os indivíduos nos lembra, na contramão de uma cultura que exige sempre o "a mais" - seja ele anatômico, cognitivo ou afetivo -, da dimensão frágil e finita da vida e ao mesmo tempo nos coloca diante de um possível negativo que "não é 
a negação do possível, tampouco se confunde com o impossível” (MALABOU, 2014, p. 61), mas é uma recusa de tudo, uma desconstrução da promessa do "sim" e, para os que o observam, uma poderosa ferramenta para se pensar os limites do poder sobre a vida.

Carvalho (2015, p. 44), fala sobre um devir deficiente, apresenta a ideia de que o acidente ontológico é ele mesmo uma das faces da condição humana, e que o deficiente e/ou acidentado, em especial, está sempre nos convocando "a ampliar as nossas perspectivas de experiência no e com o mundo". Trata-se, sobretudo, de um convite ético, o qual é corroborado por Pagni (2017, p. 1454) quando este diz que é "o encontro com esse acontecimento imprevisível e com um acidente alheio que lhe facultaria, dependendo de sua coragem, a possibilidade desse experimento de si e a disposição de se colocar do lado de outrem, sem temer a sua diferença".

Se o biopoder é positivo, modela as identidades e conduz as forças produtivas, então resistir, nessa via catastrófica, denota certo mergulho na fraqueza e fragilidade humana, no seu vazio e improviso, ou ainda num devir outro que tem algo de dissolução. No entanto, é necessário reconhecer também que na maioria das vezes o acidentado torna-se estranho ao seu acidente, é uma forma "danada", um experimento de destruição que não reconhece a sua própria imagem, "não rejeita o trauma para longe de si, não tem em relação a ele nenhum desejo, nem de comer nem de vomitar" (MALABOU, 2014, p. 65), mas, em alternativa, por meio de uma carta sem palavras e sem a devida assinatura, lança o desafio ao outro. É na relação com o outro, e no outro, que o acidente faz emergir o desejo de fuga, a vontade de viver, mover, transformar, mas não para atender à lógica da governamentalidade, senão para confrontá-la.

O acidente ou a tragédia dos corpos acidentados possui uma potência mobilizadora, move aqueles que estão a sua volta - pais, filhos, irmãos, esposos (as), amigos, professores etc. - e exige uma sensibilidade outra que não coincide com a estética de uma política de potencialização e uso mercadológico de forças vitais, mas indica um encontro com a vida mesma, com sua finitude, incertezas e possibilidades, “[...] a performatividade dessa força e o espetáculo de uma forma que se expõe ao público parece perturbar os demais modos de ser existentes, tirando-os do prumo" (PAGNI, 2017, p. 1467). Trata-se, assim, de uma forma selvagem de resistir que "força" os indivíduos a instalarem-se mais na tessitura da vida que nas embalagens das “coisas”. O acidente ontológico, nessa direção, ainda que trágico, é capaz de suscitar improvisos existenciais e insinuar formas legítimas de resistência. 


\section{CONSIDERAÇÕES FINAIS}

Ao pontuar genealogicamente o direito de "causar a morte ou deixar viver", característico do exercício do poder soberano, e sua passagem para o "poder de causar a vida ou devolver à morte" - marcando o início da modernidade, especialmente nos Estados Ocidentais -, vimos que Foucault (2014, p. 149-152) acabara por evidenciar o surgimento do biopoder, "elemento indispensável ao desenvolvimento do capitalismo". Com isso, o autor enfatiza a emergência de uma ação governamental que não se limita à aplicação da lei e à repressão da vida, mas uma ação que é positiva, transformadora e que estimula as forças vitais: primeiro, manifestando-se por meio da inserção dos corpos no aparelho de produção em uma anátomo-política - e, em seguida, ajustando os fenômenos populacionais aos processos econômicos - em uma biopolítica.

Temos que, ao ampliar a compreensão acerca da noção de biopolítica, reescrevendo-a em uma arte de governar, o pensador francês se deparou com o conceito de 
governamentalidade, então analisado à luz do liberalismo - sendo este assumido não como ideologia econômica, mas como técnica de condução da vida e crítica à arte de governar fundamentada na Razão de Estado (FOUCAULT, 2008a) - e do neoliberalismo, principalmente o norte-americano - o qual se assentou na economia de mercado e na análise econômica de relações e/ou fenômenos sociais que até o início do século XX não eram considerados genuinamente econômicos.

Após esses estudos, tomando como referência a governamentalidade neoliberal e a inserção de uma grade de inteligibilidade econômica na compreensão dos eventos sociais, vimos também que Foucault (2008b) notara que o que está em jogo na economia política contemporânea é o comportamento humano, a racionalidade interna que o anima e certa cooptação, feita pelo capital, das competências, habilidades e aptidões dos indivíduos - aliás, o indivíduo, submetido a novas estratégias de pastoreio, fora induzido a tomar a si mesmo como capital: "[...] ele quer fazer render seu corpo, seu sexo, sua comida, ele investe nas mais diversas informações para se rentabilizar, para se fazer render, para fazer render o seu tempo" (PELBART, 2000, p. 34). Com isso, o homo oeconomicus, que no liberalismo clássico era concebido como parceiro da troca, transforma-se - é subjetivado - em empresário de "si" mesmo.

Aliado a novas estratégias de pastoreio, notamos ainda que esse sujeito que fora convocado a empresariar sua própria vida, seu corpo, suas vontades, capacidades e aptidões fazendo de "si" um território de autoinvestimentos -, acabou por se transformar (e/ou ser transformado), contemporaneamente, em um outro de si mesmo: mais cerebral, neuroeconomico, flexível e instrumentalizável. De seu registro, tradicionalmente dualista (mente/corpo), o sujeito foi deslocado para o campo monista e, de "objeto" especulativo da religião e da metafísica, fora alçado a assunto científico, tornando-se alvo de mapeamento e decodificação.

Com isso, todas aquelas qualidades humanas que ao longo da história foram tidas como imateriais e/ou "sutis", aquelas marcadamente mentais, passaram a ser compreendidas como resultado causal de processos neurofisiológicos e moleculares “[...] fazendo parte de nossa história natural biológica tanto quanto a digestão, a mitose, a meiose ou a secreção enzimática" (SEARLE, 1997, p. 7). De outro modo, se no dualismo (mente/corpo) as transformações do corpo reforçavam a ideia de uma identidade individual permanente, uma vez que as mudanças corpóreas " [...] caricaturam-na ou fixam-na, nunca a contradizem, não a desarrumam" (MALABOU, 2014, p. 11), em contrapartida, na interpretação neurofisiológica, 
monista, o "si mesmo" fora tomado como entidade plástica e modulável -, podendo ser dobrado, posto a serviço de múltiplos interesses, mesmo os neoliberais, tornando-se também elemento estratégico nos cálculos biopolíticos.

Então, ao olhar mais especificamente para alguns dos elementos da biopolítica atual estímulo às forças vitais, reconfiguração biológica, crescente aumento de discursos e práticas, dentro e fora das disciplinas científicas e filosóficas que, contemporaneamente, apresentam o ser humano como um "sujeito cerebral”, plástico, passível de correção e melhoramento etc. a nossa intenção foi esclarecer o surgimento de uma política vital que, em certo sentido, associa o órgão cerebral à lógica do homo oeconomicus, ou ainda, apontar para a emergência de um atrator novo dentro do processo moderno de governo da vida.

Essa política vital, que entrevemos agora por meio de uma espécie de colonização da estrutura cerebral dos indivíduos e por sucessivos discursos que incentivam a produção e alocação de recursos raros, especialmente os cognitivos e afetivos, recebe hoje reforços da produção farmacológica, literatura de autoajuda cerebral, técnicas de neuroascese e neuroeducativas e vai ao encontro de exigências de setores produtivos, especialmente daqueles que demandam trabalho autônomo, polimorfo e criativo.

Se, outrora, o capital exigia da produção industrial o desempenho máximo de sua mão de obra - constituída de corpos disciplinados -, no modelo empresarial, por outro lado, o capital pede cérebros inovadores e/ou certa potência plástica dos indivíduos. Assim, se no filme de Chaplin, Tempos modernos, o indivíduo é confundido com as próprias engrenagens da fábrica, hoje a exigência que a lógica neoliberal lhe faz é outra: ela requer suas qualidades mais sutis, sua flexibilidade maquínica, isto é, o seu nô̂s, a sua alma, o seu sistema operacional, o seu software.

Ao reconfigurar-se, o biopoder toma em seus cálculos o governo da personalidade e subjetividade, investe hoje na gestão da mobilidade do indivíduo, em sua memória, atenção, inteligência, capacidade de decisão, comunicação, capacidade de administração da própria atividade e da de outros. Não se trata, no entanto, de mero governo de pensamento, pois, em um mundo cuja mídia encontra-se nas mãos de algumas poucas corporações globais gigantes e implacáveis, talvez não haja muito mais que a estimulação transcraniana, fármacos e ginástica cerebral possam acrescentar, por exemplo. Nem é o caso, talvez, de um "efetivo melhoramento", uma vez que o discurso acerca do aprimoramento cerebral não recai sobre qualidades como empatia, respeito às diferenças, ética, e sobre a orientação da criatividade para a produção de novas relações sociais (mais justas), mas serve apenas de reforço à 
normatividade de processos, como os cognitivos e afetivos, dos quais a estética da mercadoria é um testemunho cotidiano. O que está em pauta, enfim, é a governamentalidade da vida por meio da gestão de fenômenos mentais, uma espécie de colonização do corpo-software.

Com isso, sinalizamos uma nova linha de governo - ou uma velha forma, mas reconfigurada - apoiada menos na disciplina das mãos e mais na manipulação cognitiva e afetiva, supervisionada pelas ciências neurais e por certo discurso neuroeconomico. A ideia de um sujeito humano "empreendedor de si mesmo", cerebralmente moldável e permanentemente reconfigurável parece ganhar folego em função dos artefatos que a época oferece. E o indivíduo, preso nas teias de seu desejo - subjetivado - não deixa escapar certo esforço para reconstruir publicamente a vida, seja ela psíquica, afetiva, intelectual, corpórea etc., e dedica-se a oferecê-la ao mercado como uma mercadoria passível de troca.

De certo modo, medicar indivíduos saudáveis (estudantes, trabalhadores, soldados, entre outros) ou auto medicar-se ministrando substâncias que atuam na neuroquímica, assim como estimular práticas de si cerebrais e neuroeducativas - com o propósito de tornar os sujeitos mais obedientes, comportados, inventivos, atentos, inteligentes, organizados, competentes e competitivos -, são sintomas atuais da governabilidade biopolítica. O poder, em seu "delírio" molecular, parece incidir agora sobre as formas de perceber, sentir, amar, pensar, decidir, até mesmo de criar, e, em contrapartida, converte em transtornos as diferenças que caracterizam e enriquecem a humanidade.

O casamento entre o sujeito cerebral e a biopolítica, mesmo configurando promessas de modelação e remodelação de algumas formas de vida, atuais e futuras - promessas de torná-las normais, ou cognitivamente intensas, produtivas e "felizes" -, merece ser examinado. De maneira especial, é preciso perguntar se (ou quão efetivamente) a otimização e a normalização das capacidades cognitivas e afetivas, principalmente em virtude do neoliberalismo e da produção de recursos raros, não traem certa ética da existência - a maneira como cada um deve constituir-se e trabalhar - e, igualmente, questionar quais são os esforços necessários e os que não são - uma vez que há forças que independem de decisão voluntária, senão de um poder de explosão da vida - para manter vivo certo ímpeto de resistência.

Por fim, lembramos também que a vida, mesmo diante de poderes que a governam, ainda possui algo de ingovernável, imprevisível e humanamente selvagem. No embate com o poder, parece residir na vida mesma certa vontade de uma vida outra e, ao mesmo tempo, uma 
recusa em se levar esta vida designada e definida pelo poder. Afinal, se a biopolítica investe na vida como nunca, não seria em nome dela que se daria a resistência?

Como exemplificado, há situações em que a pessoa, de uma maneira um tanto inusitada, pode acabar dizendo "não" ou "preferiria não" a um modo específico de ser ou fazer e, diante de um poder que investe e potencializa a vida, pode insinuar certa "potência do não". Essa potência, tal como mostramos, por vezes se esboça na vontade e/ou decisão daqueles indivíduos que insistem em recusar a situação vigente, ou diz respeito a negação estética do sorriso técnico do pastoreio, ou ainda, envolve a negação do intolerável - revestido biopoliticamente de sedução. Para resistir - no "século do cérebro" - há que se admitir então certa impotência e fragilidade da vida e desmistificar a política do "a mais cognitivo", do "cérebro turbinado" e das emoções "controladas/equilibradas".

A despeito de qualquer vontade e decisão do indivíduo, a "potência do não" pode emergir ainda em sua estrutura corpórea e, repentinamente, mudar sua forma e modo de ser. Trata-se daquilo que Malabou (2014) denomina de acidente ontológico. Em qualquer instante da vida, mesmo no "auge" da existência - naquele exato momento em que, aos olhos do biopoder, a pessoa está satisfeita e feliz, ou quando já fez vários investimentos em si mesmo e tornou-se um recurso raro -, o indivíduo pode "revoltar-se" involuntariamente em seu corpo. Assim, em um lapso de indiferença, seus órgãos, células, neurônios, moléculas, genes, bioquímica etc., arrancam-lhe do fluxo do pastoreio e lhe impõe uma recusa às formas de planificação do poder. Mas como o corpo não se constitui apenas de uma infinidade de partículas (DELEUZE, 2002), senão como poder de afetar e ser afetado por outros corpos daí talvez certa ilusão epistemológica em querer reduzir o indivíduo aos seus órgãos -, as ontologias acidentas acabam por potencializar a afetividade daqueles que lhes são sensíveis, fazendo-os mover, viver, transformar e resistir. 


\section{REFERÊNCIAS}

AGAMBEN, Giorgio. Homo sacer: o poder soberano e a vida nua. Tradução de Henrique Burigo. Belo Horizonte: Editora UFMG, 2002.

AGAMBEN, Giorgio. O que é o contemporâneo? e outros ensaios. Tradução de Vinícius Nicastro Honesko. Chapecó: Argos, 2009.

AGAMBEN, Giorgio. Sobre o que podemos não fazer. In: AGAMBEN, Giorgio. Nudez. Lisboa: Relógio D’Água, 2010. p. 57-59.

AGAMBEN, Giorgio. Bartleby, ou da contingência. Tradução de Vinicius Honesko. Belo Horizonte: Autêntica Editora, 2015.

AMARAL, Jonathan Henriques. A educação no "século do cérebro": análise de interlocuções entre neurociências e educação a partir dos estudos da ciência. 2016. 126 f. Tese (Doutorado) - Universidade Federal do Rio Grande do Sul, Porto Alegre, 2016.

ANDREASEN, Nancy. Admirável cérebro novo: vencendo a doença mental na era do genoma. Tradução de José Nunes de Almeida. Lisboa: Climepsi Editores, 2003.

ARAUJO, Marcelo de. A ética do aprimoramento cognitivo: efeito Flynn e a falácia dos talentos naturais. Ethic@, Florianópolis, v. 16, n. 1, p. 1-14, 2017.

ARENDT, Hannah. A condição humana. 11. ed. Tradução de Roberto Raposo. Rio de Janeiro: Forense Universitária, 2010.

ARISTÓTELES. Metafísica. Tradução direta do grego por Vincenzo Coeco e notas de Joaquim de Carvalho. São Paulo: Abril, 1984. Livros I e II (Os Pensadores).

AZAMBUJA, Marcos Adega. Da alma para o corpo e do corpo para o cérebro: os rumos da psicologia com as neurociências. 2012. Tese (Doutorado em Psicologia) - Pontifícia Universidade Católica do Rio Grande do Sul, Porto Alegre, 2012.

AZIZE, Rogerio Lopes. A nova ordem cerebral: a concepção de "pessoa" na difusão neurocientífica. 2010. Tese (Doutorado em Antropologia Social) - Museu Nacional, Universidade Federal do Rio de Janeiro, Rio de Janeiro, 2010. 
BARBARAS, Renaud. A alma e o cérebro. Novas fronteiras entre natureza e cultura. In: NOVAES, Adauto (org.). O homem-máquina. A ciência manipula o corpo. São Paulo: Companhia das Letras, 2003. p. 65-76.

BARBARINI, Tatiane de Andrade. Sob a tutela do biopoder: crianças com TDAH. Estudos de Sociologia, Araraquara, v. 19, n. 36, p. 221-238, 2014.

BARBARINI, Tatiane de Andrade. A condição da criança hiperativa e desatenta: um estudo sobre a intervenção psiquiátrica nas formas contemporâneas de inserção social infantil. 2016. Tese (Doutorado em Sociologia) - Instituto de Filosofia e Ciências Humanas, Universidade Estadual de Campinas, Campinas, 2016.

BARROS, Denise Borges. Aprimoramento cognitivo farmacológico: grupos focais com universitários. 2009. Dissertação (Mestrado em Saúde Coletiva) - Instituto de Medicina Social, Universidade Estadual do Rio de Janeiro, Rio de Janeiro, 2009.

BARROS, Denise Borges; ORTEGA, Francisco. Metilfenidato e aprimoramento cognitivo farmacológico: representações sociais de universitários. Saúde e Sociedade, São Paulo, v. 20, n. 2, p. 350-362, 2011.

BARROS, Manoel de. O livro das ignorãças. 3. ed. Rio de Janeiro: Civilização Brasileira, 1993.

BARROS, Manoel de. Memórias inventadas: a infância. São Paulo: Planeta, 2003.

BECKER, G. S. Human capital: a theoretical and empirical analysis, with special reference to education. Chicago: The University of Chicago Press, 1964.

BLÉFARI, Rosario; PAMPÍN, Susana. Somos nuestro cérebro: ensayo de divulgación científica. Buenos Aires: Libros del Rojas; Universidad de Buenos Aires, 2003. (Peça de teatro sobre textos de Sergio Strejilevich).

BOUTANG, Yann Moulier. O território e as políticas de controle do trabalho no capitalismo cognitivo. In: GALVÃO, Alexander; SILVA, Gerardo; COCCO, Giuseppe. Capitalismo cognitivo. Rio de Janeiro: DP\&A, 2003. p. 33-60.

BRANT, Luiz Carlos; CARVALHO, Tales Renato F. Metilfenidato: medicamento gadget da contemporaneidade. Interface - Comunicação, Saúde, Educação, Botucatu, v. 16, n. 42, p. 623-36, 2012. 
BRUM, Eliane. Acordei doente mental. A quinta edição da "Bíblia da Psiquiatria", o DSM-5, transformou numa "anormalidade" ser "normal". Época, Rio de Janeiro, 20 maio 2013. Disponível em: http://revistaepoca.globo.com/Sociedade/elianebrum/noticia/2013/05/acordei-doente-mental.html. Acesso em: 15 mar. 2019.

BUTCHER, J. Cognitive enhancement raises ethical concerns. Lancet, Stanford, CA, v. 362, n. 9.378, p. 132-133, 2003. Disponível em:

http://neuroethics.stanford.edu/documents/Neuroethics_Lancet_feature.pdf. Acesso em: $1 \mathrm{abr}$. 2018 .

CAINE, Renate N.; CAINE, Geoffrey C. Making connections: teaching the human brain. Menlo Park, CA: Addison-Wesley, 1994.

CALDWELL, J.; CALDWELL, L. Fatigue in military aviation: an overview of US military approved pharmacological countermeasure. Aviation, Space, and Environmental Medicine, Alexandria, v. 76, n. 7, p. 39-51, 2004.

CALIMAN, Luciana. Os regimes da atenção na subjetividade contemporânea. Arquivos Brasileiros de Psicologia, Rio de Janeiro, v. 64, n. 1, p. 2-17, 2012.

CARVALHO, Alexandre Filordi. Por uma ontologia política da (d)eficiência no governo da infância. In: RESENDE, Haroldo de. Michel Foucault: o governo da infância. Belo Horizonte: Editora Autêntica, 2015, p. 25-47.

CANGUILHEM, G. O normal e o patológico. 6. ed. rev. Rio de Janeiro: Forense Universitária, 2006.

CERTEAU, Michel de. A invenção do cotidiano: 1. artes de fazer. Petrópolis: Vozes, 1994.

CHANGEUX, Jean-Pierre. O homem neuronal. Lisboa: Publicações Dom Quixote, 1985.

CORSANI, Antonella. Elementos de uma ruptura: a hipótese do capitalismo cognitivo. In: GALVÃO, Alexander; SILVA, Gerardo; COCCO, Giuseppe. Capitalismo cognitivo. Rio de Janeiro: DP\&A, 2003. p. 15-30.

COSTA, Jurandir Freire. O vestígio e a aura: corpo e consumismo na moral do espetáculo. Rio de Janeiro: Garamond, 2004. 
COSENZA, Ramon M.; GERRA, Leonor B. Neurociência e educação: como o cérebro aprende. Porto Alegre: Artmed, 2011.

CRARY, Jonathan. 24/7 - o capitalismo tardio e os fins do sono. Tradução de Joaquim Toledo Jr. São Paulo: Ubu Editora, 2016.

DAMÁSIO, António R. O erro de Descartes: emoção, razão e o cérebro humano. Tradução de Dora Vicente e Georgina Segurado. São Paulo: Companhia das Letras, 1996.

DAWKINS, Richard. O capelão do diabo: ensaios escolhidos. Tradução de Rejane Rubino. São Paulo: Companhia das Letras, 2005.

DELEUZE, Gilles. Crítica e clínica. Tradução de Peter Pál Pelbart. São Paulo: Editora 34, 2011.

DELEUZE, Gilles. Post-scriptum sobre as sociedades de controle. In: DELEUZE, G.

Conversações. Tradução de Peter Pál Pelbart. Rio de Janeiro: Editora 34, 1992.

DELEUZE, Gilles. Espinosa: filosofia prática. São Paulo: Escuta, 2002.

DESCARTES, R. Discurso do método. Meditações. Objeções e respostas. As paixões da alma. Cartas. Tradução de J. Guinsburg e Bento Prado Júnior. São Paulo: Abril Cultural, 1973. (Os Pensadores).

DOSTOIÉVSKI, Fiódor. Memórias do subsolo. Tradução de Boris Schaiderman. São Paulo: Editora 34, 2000.

DUARTE, André. Vidas em risco: crítica do presente em Heidegger, Arendt e Foucault. Rio de Janeiro: Forense, 2010.

EDELMAN, Gerald M. Biologia da consciência: as raízes do pensamento. 1. ed. Lisboa: Instituto Piaget, 1995.

EDMONDS, Alexander; SANÁBRIA, Emilia. Entre saúde e aprimoramento: a engenharia do corpo por meio das cirurgias plásticas e terapias hormonais no Brasil. História, Ciência, Saúde - Manguinhos, Rio de Janeiro, v. 23, n. 1, p. 193-210, 2016. 
EHRENBERG, Alain. O sujeito cerebral. Revista de Psicologia Clínica, Rio de Janeiro, v. 21, n. 1, p. 187-213, 2009.

EHRENBERG, Alain. O culto da performance: da aventura empreendedora à depressão nervosa. Organização e tradução de Pedro F. Bendassolli. Aparecida: Ideias \& Letras, 2010.

ESPOSITO, Roberto. Bios: biopolítica e filosofia. Tradução de Wander Melo Miranda. Belo Horizonte: Editora UFMG, 2017.

ÉSQUILO. Prometeu acorrentado. In: ÉSQUILO: Prometeu acorrentado. Sófocles: Ajáx. EURÍPEDES: Alceste. Tradução de Mario da Gama Kury. Rio de Janeiro: Jorge Zahar Editor, 1999. (Tragédia Grega, VI).

EURÍPIDES. Orestes. Tradução de Augusta Fernanda de Oliveira e Silva. Coimbra: Instituto Nacional de Investigação Científica, 1982.

FIORE, Nicole. As neurociências cognitivas. Tradução de Sonia M. S. Fuhrmann. Petrópolis: Vozes, 2008.

FLECK, L. Gênese e desenvolvimento de um fato científico. Belo Horizonte: Fabrefactum, 2010.

FOUCAULT, Michel. “O sujeito e o poder”. In: DREYFUS, Hubert L.; RABINOW, Paul. Michel Foucault: uma trajetória filosófica. Para além do estruturalismo e da hermenêutica. Rio de Janeiro: Forense Universitária, 1995. p. 231-249.

FOUCAULT, Michel. O que é a crítica?: (crítica ou Aufklarung). In: BIROLI, Flávia; ALVAREZ, Marcos César (org.). Michel Foucault: histórias e destinos de um pensamento. Cadernos da Faculdade de Filosofia e Ciências, Marília, v. 9, n.1, 2000.

FOUCAULT, Michel. Em defesa da sociedade. Tradução de Maria Ermantina Galvão. Curso dado no Collège de France (1975-1976). São Paulo: Martins Fontes, 2005.

FOUCAULT, Michel. A hermenêutica do sujeito. Tradução de Márcio Alves da Fonseca e Salma Tannus Muchail. São Paulo: Martins Fontes, 2006.

FOUCAULT, Michel. Segurança, território e população. Tradução de Eduardo Brandão. Curso dado no Collège de France (1977-1978). São Paulo: Martins Fontes, 2008a. 
FOUCAULT, Michel. Nascimento da biopolítica. Tradução de Eduardo Brandão. Curso dado no Collège de France (1978-1979). São Paulo: Martins Fontes, 2008b.

FOUCAULT, Michel. O corpo utópico, as heterotopias. Tradução de Salma Tannus Muchail. São Paulo: N-1 Edições, 2013a.

FOUCAULT, Michel. A vida: a experiência e a ciência. In: Ditos e escritos II: arqueologia das ciências e história dos sistemas de pensamento: organização Manuel Barros da Mota; tradução Elsa Monteiro. 3. ed. Rio de Janeiro: Forense Universitária, 2013 b.

FOUCAULT, Michel. História da loucura: na Idade clássica. Tradução de José Teixeira Coelho Neto. São Paulo: Perspectiva, 2013c.

FOUCAULT, Michel. Vigiar e punir: história da violência nas prisões. Tradução de Raquel Ramalhete. 41. ed. Petrópolis: Vozes, 2013d.

FOUCAULT, Michel. História da sexualidade 1: a vontade de saber. Tradução de Maria Thereza da Costa Albuquerque e J. A. Guilhon Albuquerque. 1. ed. São Paulo: Paz e Terra, 2014.

FOUCAULT, Michel. Microfísica do poder. Organização, introdução e revisão técnica de Roberto Machado. 2. ed. Rio de Janeiro: Paz e Terra, 2015.

FREITAS, Alexandre Simão. O devir-deficiente da pedagogia: notas para uma antropologia filosófica-educacional da plasticidade. Childhood and Philosophy, Rio de Janeiro, v. 12, n. 24, p. 227-248, maio/ago. 2016.

FURTADO, Rafael Nogueira. Desafios éticos das tecnologias de melhoramento humano. Revista Kínesis, Marília, v. 9, n. 20, p. 235-251, 2017.

GADELHA, Sylvio. Biopolítica, governamentalidade e educação: introdução e conexões a partir de Michel Foucault. Belo Horizonte: Autêntica, 2009.

GALENO, C. L'âme et ses passions. Les passions et les erreurs de l'âme. Les âmes suivent les tempéraments du corps. Tradução e notas de V. Barras, T. Birchler, A-F. Morand. Paris: Les Belles Lettres, 1995. 
GIBSON, James J. The ecological approach to visual perception. New Jersey: Lawrence Earlbaum Associates, 1986.

GREELY, H. et al. Towards responsible use of cognitive-enhancing drugs by the healthy. Nature, London, v. 456, n. 7.223, p. 702-705, 11 Dec. 11 ${ }^{\text {th }}$, 2008. Disponível em:

https://repository.upenn.edu/cgi/viewcontent.cgi?article=1039\&context=neuroethics_pubs. Acesso em: 28 maio 2018.

GROS, Frédéric. Desobedecer. Tradução de Célia Euvaldo. São Paulo: Ubu Editora, 2018.

GUARIDO, Renata. A medicalização do sofrimento psíquico: considerações sobre o discurso psiquiátrico e seus efeitos na educação. Educação e Pesquisa, São Paulo, v. 33, n. 1, p. 151161, jan./abr. 2007.

HAN, Byung-Chul. Sociedade do cansaço. Tradução de Ênio Paulo Giachini. Petrópolis: Vozes, 2017.

HEBB, Donald Olding. The organization of behavior: a neuropsychological theory. New York: Wiley, 1949.

HESÍODO. Teogonia: a origem dos deuses. Tradução de Jaa Torrano. 2. ed. São Paulo, Iluminuras, 2012.

HOMERO. Odisséia. Tradução de Carlos Alberto Nunes. Rio de Janeiro: Ediouro, 2004.

IRIART, C.; IGLESIAS-RIOS, L. La (re)creación del consumidor de salud y la biomedicalización de la infância. In: COLLARES, C. A. L.; MOYSÉS, M. A. A.; RIBEIRO, M. C. F. (org.). Novas capturas, antigos diagnósticos na era dos transtornos. Campinas: Mercado de Letras, 2013. p. 21-40.

ITABORAHY, Claudia. A Ritalina no Brasil: uma década de produção, divulgação e consumo. 2009. Dissertação (Mestrado em Medicina Social) - Instituto de Medicina Social, Universidade do Estado do Rio de Janeiro, Rio de Janeiro, 2009.

JAEGER, W. Paideia: a formação do homem grego. Tradução de Artur M. Parreira. São Paulo: Martins Fontes, 1995. 
JENSEN, Eric. Enriching the brain: how to maximize every learner's potential. San Francisco: Jossey-Bass, 2006.

KORN, H. (org.). Neurosciences et maladies du système nerveux. Paris: Académie des Sciences, 2003. p. xxvii-xxxii. (Rapport sur la Science et la Technologie, 16).

LAJONQUIÈRE, Leandro de. Figuras do infantil: a psicanálise na vida cotidiana com as crianças. Petrópolis: Vozes, 2010.

LAZZARATO, Maurizio. Para uma definição do conceito de "bio-política". Lugar Comum, Rio de Janeiro, n. 5-6, p. 81-96, 1999. Tradução de Eliana Aguiar. Disponível em: http://goo.gl/jVNkhi. Acesso em: 28 mar. 2018.

LAZZARATO, Maurizio. Trabalho e capital na produção dos conhecimentos: uma leitura através da obra de Gabriel Tarde. In: GALVÃO, Alexander; SILVA, Gerardo; COCCO, Giuseppe. Capitalismo cognitivo. Rio de Janeiro: DP\&A, 2003. p. 61-82.

LAZZARATO, Maurizio. As revoluções do capitalismo. Tradução de Leonora Corsini. Rio de Janeiro: Civilização Brasileira, 2006.

LAZZARATO, Maurizio; NEGRI, Antonio. Trabalho imaterial: formas de vida e produção de subjetividade. Tradução de Monica Jesus. Rio de Janeiro: DP\&A, 2001.

LIMA, Elvira Souza. Neurociência e aprendizagem. São Paulo: Interalia, 2010.

LISBOA, Felipe Stephan. O cérebro vai à escola: aproximações entre neurociências e educação no Brasil. Jundiaí: Paco Editorial, 2016.

LÓPEZ-RUIZ, Oswaldo. Os executivos das transnacionais e o espírito do capitalismo: capital humano e empreendedorismo como valores sociais. Rio de Janeiro: Azougue Editorial, 2007.

MALABOU, Catherine. Ontologia do acidente: ensaio sobre a plasticidade destrutiva. Tradução de Fernando Scheibe. Florianópolis: Cultura e Barbárie, 2014.

MARÍN-DÍAZ, Dora Lilia. Autoajuda, educação e práticas de si: genealogia de uma antropotécnica. Belo Horizonte: Autentica Editora, 2015. 
MATURANA, Humberto; VARELA, Francisco J. A árvore do conhecimento: as bases biológicas da compreensão humana. Tradução de Humberto Mariotti e Lia Diskin. São Paulo: Palas Athena, 2004.

MELVILLE, Herman. Bartleby, o escrivão: uma história de Wall Street. Tradução de Irene Hirsch. São Paulo: Cosac Naify, 2005.

MENDES, Diego José D.; IBRAIN, Jayane V. A criminologia etiológica contemporânea: visão psicossocial do desenvolvimento para o crime versus a predisposição genética para a delinquência. Revista Eletrônica da Faculdade Sete de Setembro, Paulo Afonso, n. 12, p. 111-124, 2017.

MOYSÉS, Maria Aparecida A.; COLLARES, Cecília A. L. Medicalização: o obscurantismo reinventado. In: COLLARES, Cecília; MOYSÉS, Maria Aparecida; RIBEIRO, Mônica Cintrão (org.). Novas capturas, antigos diagnósticos na era dos transtornos: memórias do II Seminário Internacional Educação Medicalizada: dislexia, TDAH e outros supostos transtornos. Campinas: Mercado de Letras, 2013. p. 41-64.

NIETZSCHE, Friedrich Wilhelm. Sobre verdade e mentira no sentido extra-moral. Tradução e organização de Fernando de Moraes Barros. São Paulo: Hedra, 2007.

OCDE - ORGANIZAÇÃO PARA A COOPERAÇÃO E DESENVOLVIMENTO ECONÔMICO. Compreendendo o cérebro: rumo a uma nova ciência do aprendizado. São Paulo: SENAC, 2003.

OLIVEIRA, Gilberto Gonçalves de. Neurociências e os processos educativos: um saber necessário na formação dos professores. Educação Unisinos, São Leopoldo, v. 18, n. 1, p. 13-24, jan./abr. 2014.

ORTEGA, Francisco. O corpo incerto: corporeidade, tecnologias médicas e cultura contemporânea. Rio de Janeiro: Garamond, 2008a.

ORTEGA, Francisco. O sujeito cerebral e o movimento da neurodiversidade. Mana, Rio de Janeiro, v. 14, n. 2, p. 477-509, 2008b. Disponível em:

http://www.scielo.br/scielo.php?script=sci_arttext\&pid=S0104-93132008000200008. Acesso em: 22 maio 2019.

ORTEGA, Francisco. Elementos para uma história da neuroascese. História, Ciências, Saúde - Manguinhos, Rio de Janeiro, v. 16, n. 3, p. 621-640, 2009a. 
ORTEGA, Francisco. Neurociências, neurocultura e autoajuda cerebral. Interface Comunicação, Saúde, Educação, Botucatu, v. 13, n. 31, p. 247-260, 2009 b.

ORTEGA, Francisco; VIDAL, Fernando. Mapeamento do sujeito cerebral na cultura contemporânea. RECIIS - Revista Eletrônica de Comunicação, Informação e Inovação em Saúde, Rio de Janeiro, v. 1, n. 2, p. 257-261, 2007.

ORTEGA, Francisco; ZORZANELLI, Rafaela. Corpo em evidência. A ciência e a redefinição do humano. Rio de Janeiro: Civilização Brasileira, 2010.

PAGNI, Pedro Angelo. A Deficiência em sua Radicalidade Ontológica e suas Implicações Éticas para as Políticas de Inclusão Escolar. Educação e Filosofia, Uberlândia, v. 31, n. especial, p. 1443-1474, 2017a.

PELBART, Peter Pál. Ensaios do assombro. São Paulo: n-1 edições, 2019.

PELBART, Peter Pál. Da claustrofobia contemporânea. In: PELBART, Peter Pál. A vertigem por um fio. Políticas da subjetividade contemporânea. São Paulo: Iluminuras, 2000. p. 21-39.

PELBART, Peter Pál. Vida capital: ensaios de biopolítica. São Paulo: Iluminuras, 2003.

PELBART, Peter Pál. Biopolítica. Sala Preta, São Paulo, v. 7, p. 57-66, 2007. https://doi.org/10.11606/issn.2238-3867.v7i0p57-66.

PELBART, Peter Pál. Vida capital: ensaios de biopolítica. São Paulo: Iluminuras, 2009.

PESSOA, Fernando. Poemas de Álvaro de Campos. São Paulo: Companhia das Letras, 2007.

PLATÃO. Fédon. In: PLATÃO. Diálogos: Eutífron, Apologia de Sócrates, Críton e Fédon. Tradução de José Cavalcante de Souza. São Paulo: Nova Cultural, 1999. (Os Pensadores).

PRECIADO, Paul B. Testo Junkie: sexo, drogas e biopolítica na era farmacopornográfica. Traduzido de Maria Paula Gurgel Ribeiro. São Paulo: N-1 Edições, 2018.

PROUST, Joëlle. Autocontrole: em direção a um novo homem? In: NOVAES, Adauto (org.). A condição humana. As aventuras do homem em tempos de mutações. Rio de Janeiro: Agir; São Paulo: SESC, 2009. p. 341-373. 
RABINOW, Paul. Antropologia da razão: ensaios de Paul Rabinow. Organização e tradução de João Guilherme Biehl. Rio de Janeiro: Relume Dumará, 1999.

RAINE, Adrian. A anatomia da violência: as raízes biológicas da criminalidade. Tradução de Maiza Ritomy Ite. Porto Alegre: Artmed, 2015.

RELVAS, Marta Pires. Neurociência e educação: potencialidades dos gêneros humanos na sala de aula. Rio de Janeiro: Wak Editora, 2010.

RELVAS, Marta Pires (org.). Que cérebro é esse que chegou à escola? As bases neurocientíficas da aprendizagem. Rio de Janeiro: Wak Editora, 2012.

RIBEIRO, Renato Janine. Novas fronteiras entre natureza e cultura. In: NOVAES, Adauto (org.). O homem-máquina. A ciência manipula o corpo. São Paulo: Companhia das Letras, 2003. p. 15-36.

RIBEIRO, Sidarta. Tempo de cérebro. Estudos Avançados, São Paulo, v. 27, n. 77, p. 718 , 2013.

RITALINA: comprimidos. Farmacêutica Responsável: Flavia Regina Pegorer. São Paulo: Novartis Biociências S.A. Disponível em: https://www.bulas.med.br/p/bulas-demedicamentos/bula/3721/ritalina.htm. Acesso em: 28 maio 2018.

ROSE, Nikolas. Cérebro, self e sociedade: uma conversa com Nikolas Rose. Physis Revista de Saúde Coletiva, Rio de Janeiro, v. 20, n. 1, p. 301-324, 2010.

ROSE, Nikolas. A política da própria vida. Biomedicina, poder e subjetividade no século XXI. Tradução de Paulo Ferreira Valério. São Paulo: Paulus, 2013.

ROSE, Steven P. R. O cérebro do século XXI: como entender, manipular e desenvolver a mente. Tradução de Helena Londres. São Paulo: Globo, 2006.

ROUSSEAU, Jean-Jacques. Economia (moral e política). In: DIDEROT, Denis; D’ALEMBERT, Jean le Ronde. Verbetes políticos da Enciclopédia. Tradução de Maria das Graças de Souza. São Paulo: Discurso; UNESP, 2006. p. 83-127.

RYLE, Gilbert. The concept of mind. Londres: Penguin Books, 2000. 
SACKS, Oliver W. O homem que confundiu sua mulher com um chapéu e outras histórias clínicas. Tradução de Laura Teixeira Motta. São Paulo: Companhia das Letras, 1997.

SANTOS, Boaventura de Sousa. A construção multicultural da igualdade e da diferença. Coimbra: Oficina do CES, 1999.

SCHULTZ, Teodor. W.O capital humano: investimentos em educação e pesquisa. Tradução de Marco Aurélio de Moura Matos. Rio de Janeiro: Zahar, 1973.

SEARLE, John R. A redescoberta da mente. Tradução de Eduardo Pereira e Ferreira. São Paulo: Marins Fontes, 1997.

SIBILIA, Paula. O homem pós-orgânico: corpo, subjetividade e tecnologias digitais. Rio de Janeiro: Relume Dumará, 2002.

SILVA, Divino J.; VAZ, Alexandre F. A emergência do sujeito cerebral e suas implicações para a educação. Childhood \& Philosophy, Rio de Janeiro, v. 12, n. 24, p. 211-230, 2016.

SIQUEIRA, Cláudia Machado; GURGEL-GIANNETTI, Juliana. Mau desempenho escolar: uma visão atual. Revista da Associação Médica Brasileira, São Paulo, v. 57, n. 1, p. 78-87, 2011.

SÓFOCLES. Édipo rei. Tradução de Trajano Vieira. São Paulo: Perspectiva, 2001.

SPINOZA, Benedictus de. Ética. Tradução de Tomaz Tadeu da Silva. Belo Horizonte: Autêntica, 2009.

TEIXEIRA, Josele. Neurociência e psicologia. In: RELVAS, Marta Pires (org.). Que cérebro é esse que chegou à escola? As bases neurocientíficas da aprendizagem. Rio de Janeiro: Wak Editora. p. 113-120.

TEIXEIRA, Monica. Notícia preliminar sobre uma tendência contemporânea: o "aperfeiçoamento cognitivo", do ponto de vista da pesquisa em neurociências. Revista Latino-Americana de Psicopatologia Fundamental, São Paulo, v. 10, n. 3, p. 495-503, 2007. 
TEMPOS MODERNOS. Direção, produção e roteiro: Charles Chaplin. Elenco: Charles Chaplin, Paulette Goddard, Henry Bergman, Stanley Sandford, Chester Conklin. Nova Iorque: Charlie Chaplin Film Corporation, 1936, 87 min.

TOKUHAMA-ESPINOSA, T. N. The scientifically substantiated art of teaching: a study in the development of standards in the new academic field of neuroeducation (mind, brain, and education science). 2008. Thesis (Doctorate) - Graduate Program in Education, Capella University, Mineápolis, Minesota, 2008.

TRIGUEIRO, Emilia Suitberta de Oliveira. Adolescentes, o aprimoramento cognitivo farmacológico e o acesso ao ensino superior. 2017. Tese (Doutorado em Psicologia) Instituto de Psicologia, Universidade de São Paulo, São Paulo, 2017.

VARELA, F. J.; THOMPSON, E.; ROSCH, E. A mente corpórea: ciência cognitiva e experiência humana. Tradução de Joaquim Nogueira Gil e Jorge de Souza. Lisboa: Instituto Piaget, 2001.

VEIGA-NETO, Alfredo. Governamentalidade e educação. Revista Colombiana de Educação, Bogotá, n. 65, p. 19-41, 2013. Disponível em:

http://www.redalyc.org/pdf/4136/413634077002.pdf. Acesso em: 19 abr. 2019.

VIDAL, Fernando. O sujeito cerebral: um esboço histórico e conceitual. Polis e Psique, Porto Alegre, v. 1, n. 1, p. 226-253, 2011. Tradução de Maria Elísia Flores.

WILHELM, Ines et al. Sleep selectively enhances memory expected to be of future relevance. Journal of Neuroscience, Washington, CC, v. 31, n. 5, p. 1.563-1.569, Feb. $2^{\text {nd }}, 2011$. https://doi.org/10.1523/JNEUROSCI.3575-10.2011.

WILLIS, Judy. Research-based strategies to ignite student learning: insights from a neurologist and classroom teacher. Virginia: ASCD, 2006.

WINOGRAD, Monah. O sujeito das neurociências. Trabalho Educação e Saúde, Rio de Janeiro, v. 8, n. 3, p. 521-535, 2010.

ZARO, Milton Antônio et al. Emergência da neuroeducação: a hora e a vez da neurociência para agregar valor à pesquisa educacional. Revista Ciência \& Cognição, Rio de Janeiro, v. 15, n. 1, p. 199-210, 2010. Disponível em:

http://www.cienciasecognicao.org/pdf/v15_1/m276_10.pdf. Acesso em: 18 abr. 2019. 
ZIZEK, Slavoj. O trauma neural. In: NOVAES, Adauto (org.). A condição humana. As aventuras do homem em tempos de mutações. Rio de Janeiro: Agir; São Paulo: SESC, 2009. p. 149-184.

ZORZANELLI, Rafaela Teixeira; ORTEGA, Francisco. Cultura somática, neurociências e subjetividade contemporânea. Psicologia \& Sociedade, Belo Horizonte, v. 23, n. spe, p. 3036, 2011. 